\title{
A Coordination-Based Approach to Subnational Variations in Split- Ticket Voting: The Case of Ghana 1996-2016
}

\author{
Samuel Kofı Darkwa \\ West Virginia University, samdarkgh@gmail.com
}

Follow this and additional works at: https://researchrepository.wvu.edu/etd

Part of the Comparative Politics Commons

\section{Recommended Citation}

Darkwa, Samuel Kofi, "A Coordination-Based Approach to Subnational Variations in Split-Ticket Voting: The Case of Ghana 1996-2016" (2019). Graduate Theses, Dissertations, and Problem Reports. 4065. https://researchrepository.wvu.edu/etd/4065

This Dissertation is protected by copyright and/or related rights. It has been brought to you by the The Research Repository @ WVU with permission from the rights-holder(s). You are free to use this Dissertation in any way that is permitted by the copyright and related rights legislation that applies to your use. For other uses you must obtain permission from the rights-holder(s) directly, unless additional rights are indicated by a Creative Commons license in the record and/ or on the work itself. This Dissertation has been accepted for inclusion in WVU Graduate Theses, Dissertations, and Problem Reports collection by an authorized administrator of The Research Repository @ WVU.

For more information, please contact researchrepository@mail.wvu.edu. 


\title{
A Coordination-Based Approach to Subnational Variations in Split-Ticket Voting: The Case of Ghana 1996-2016
}

\section{Samuel Kofi Darkwa}

Dissertation submitted to the John D. Rockefeller IV School of Policy and Politics within the Eberly College of Arts and Sciences at West Virginia University in partial fulfillment of the requirements for the degree of Doctor of Philosophy in Political Science

\author{
Erik Herron, Ph.D., Chair \\ Matthew Jacobsmeier, Ph.D. \\ Mason Moseley, Ph.D. \\ Jay Krehbiel, Ph.D. \\ Tamba M'bayo, Ph.D
}

\section{Department of Political Science}

\author{
Morgantown, West Virginia \\ 2019
}

Keywords: Split-ticket voting, skirt and blouse voting, elite coordination, inter and intraparty coordination, Ghana, democracy

Copyright 2019 Samuel Kofi Darkwa 


\title{
Abstract \\ A Coordination-Based Approach to Subnational Variations in Split-Ticket Voting: The Case of Ghana 1996-2016
}

\author{
Samuel K. Darkwa
}

This dissertation seeks to explain the causes of split-ticket voting (skirt and blouse voting) in emerging democracies like Ghana. The analysis carried out here has been approached at three levels. This is because voters' decisions in the voting booth are affected by factors within the larger political environment which are often beyond the individual voter. Thus, the three approaches employed here consider individual-level, constituency-level, and elite-level factors that affect the phenomenon. In each case different datasets were used to examine split-ticket voting. The analysis reveals that the individual-level factors (demographic characteristics and political information variables) are weak in explaining ticket splitting. Aside from their statistically weak relationship with ticket splitting, they are inconsistent in explaining the phenomenon. The most important factors shaping split-ticket voting, however, operate at the elite-level, and are coordination based. Using the Afrobarometer survey, constituency level electoral data, and a fieldwork survey, the analysis finds elite-level factors which are based on coordination successes and failures within and between parties as the best predictors of ticket splitting. The reason for this is that elite coordination successes and failures affect the available choice sets at any given election and these largely affect ticket splitting. I argue that differences in ticket splitting are better explained by variation in the degree of coordination among elite actors than by variation in characteristics of individual voters such as political sophistication. 


\section{Dedication}

I would like to dedicate this work to my sweet wife Betty and my three beautiful daughters; Onyame Animuonyam, Onyame Nhyira and Onyame Nkunimdie for their patience and understanding that made it possible for me to spend long hours working on this Dissertation. Sweetheart, I am extremely grateful to you for your invaluable support in this project.

I also dedicate this dissertation to the memory of my mother, Ruth Adwoa Donkor whose stern training toughened me and built in me character and zeal. It was unfortunate she did not live to see this day she most cherished. Her untimely death happened while I was out here pursuing my graduate studies and could not travel back to pay her my last respect. I will forever remember her for her principles and sternness balanced with love. 


\section{Acknowledgements}

First and foremost, I give thanks to the Lord God Almighty for bringing me thus far in my education and research - He picked me from ashes and set my foot upon a Rock; I am forever grateful! Special thanks go to my Committee Chair, Professor Erik Herron, of the Department of Political Science at West Virginia University whose meticulousness during the supervision brought a lot of difference to this work. Indeed, without his considerable academic support I could never have completed this Dissertation.

Thanks also go to the other members of my Dissertation Committee; Prof. Matthew Jacobsmeier (Director of Graduate Studies, Department of Political Science), Professor Tamba M'bayo (Department of History), Professor Jay Krehbiel and Professor Mason Moseley (both at the Department of Political Science) whose valuable critique made this work a success.

Special thanks also go to my boss, Mrs. Jean Mensa, the Commissioner of Electoral Commission of Ghana (former Executive Director of the IEA Ghana) for providing me office space during my field trip to Ghana and for linking me with most of my research subjects who are political heavy weights in Ghana. She really made it easy for me to collect the critical data for this project and beyond. I am also indebted to Professor Bossman Asare, the Deputy Commissioner of Electoral Commission of Ghana who was then the Chair of the Political Science Department at the University of Ghana, Legon. He granted me interview and connected me with student leaders and important stakeholders in Ghanaian electoral politics.

Last but not the least, I am especially grateful to the pastors and the leadership of the Dispensational Gospel Mission Ghana for their mentoring role in my life. I am most grateful to Rev. Edward Frempong, who identified the potential in me and encouraged me to go to high school at a time I had no hope for high school education let alone college education. He is God sent and I am grateful to him for allowing God to use him to transform my life and that of many. Posterity will remember him for good. 
Samuel K. Darkwa

\section{Table of Contents}

Abstract

Dedication

Acknowledgements

iv

Table of Contents

List of Tables

vi

List of Figures

vii

List of Appendixes

viii

CHAPTER 1. GENERAL INTRODUCTION

1.1 Introduction

1.2 Definition for Ticket Splitting

1.2.1 Working Definition for Ticket Splitting

1.3 A Brief Review of the Ticket Splitting Literature

1.4 Distinction between Split-Ticket Voting and Strategic Voting

1.5 General Overview of the Dissertation

1.6 References

1.7 Notes

CHAPTER 2. DEVELOPING A CONCEPTUAL FRAMEWORK

2.1 Introduction

2.2 Strategic Coordination Theory

2.3 Strengths and Weaknesses of the Theory

2.4 Why Ghana

2.5 References

2.6 Notes

CHAPTER 3. INDIVIDUAL LEVEL OF ANALYSIS 42

3.1 Chapter Introduction

3.2 Theories on Ticket Splitting at the Individual Level

3.3 Data and Measurement

3.4 Estimation Strategy for Voter Choice under Coordination Theory

3.5 Conclusion 
Samuel K. Darkwa

$\begin{array}{lr}3.7 \text { Notes } & 90\end{array}$

CHAPTER 4. AGGREGATE LEVEL OF ANALYSIS 103

4.1 Chapter Introduction 103

4.2 Theories on Ticket Splitting and Split Constituency Outcome 110

4.3 Data and Measurement 124

4.4 Estimation Strategy for Skirt and Blouse Outcome under Coordination Theory 129

4.5 Conclusion 141

4.6 References 144

$\begin{array}{ll}4.7 \text { Notes } & 151\end{array}$

CHAPTER 5. ELITE LEVEL OF ANALYSIS 154

5.1 Chapter Introduction 154

5.2 Discoveries from the Fieldwork 157

5.3 Strategic Coordination Theory 166

5.4 Alternative Explanations 177

5.5 Data and Measurement 182

5.6 Modeling Intraparty/Interparty Coordination Theory 190

$\begin{array}{ll}5.7 \text { Conclusion } & 202\end{array}$

$\begin{array}{ll}5.8 \text { References } & 207\end{array}$

$\begin{array}{ll}5.9 \text { Notes } & 211\end{array}$

$\begin{array}{ll}\text { CHAPTER 6. } & 214\end{array}$

6.1 Findings from the Research 214

6.2 Contribution to the Split-Ticket Voting Literature 218

6.3 Limitations of the Research 219

6.4 Recommendations for Future Research in the Subfield 221

$\begin{array}{ll}6.5 \text { References } & 224\end{array}$

\section{List of Tables}

Table 1.1: Ticket Splitting Across Offices and Time 5

Table 2.1: Observable Indicators of Intraparty Coordination and Possible Impact on Splitting 33

Table 2.2: Observable Indicators of Interparty Coordination and Possible Impact on Splitting 35

Table 3.1: Respondents' Closeness to the Legislative Candidates 64 
Table 3.2: Respondents' Closeness to the Presidential Candidates 64

Table 3.3: Actual Performance of Presidential \& Legislative Candidates in 2016 Elections 64

Table 3.4: Logit Analysis of Skirt and Blouse Voting with missing data 71

Table 3.5: Logit Analysis of Skirt and Blouse Voting with multiple imputation 72

Table 3.6: Effect of Changing Variables from Their Minimum to Maximum Values on 74

Probability of Ticket Splitting

Table 4.1: Descriptive Statistics of Disputed Primaries in Parliamentary Elections $(1996-2016)$

Table 4.2: Logit Analysis of Skirt \& Blouse Outcome (Control Variables Only)

Table 4.3: Logit Analysis of Skirt \& Blouse Outcome (Independent Variables Only)

Table 4.4: Logit Analysis of Skirt \& Blouse Outcome Using Aggregate Electoral Data (All Variables)

Table 4.5: Logit Analysis of Skirt \& Blouse Outcome Using Aggregate Electoral Data 19962016 (With Year Dummies)

Table 4.6: Effect of Changing Variables from their Minimum to Maximum Values on Probability of Ticket Splitting

Table 4.7: Percentage of Split Constituencies vs. Disputed Primaries in Parliamentary Elections 1996 - 2016

Table 4.8: Presidential and Parliamentary Winners and Runners-Up 1992 - 2016

Table 5.1 Presidential Election Results 1996 - 2016

Table 5.2 Parliamentary Election Results 1996 - 2016

Table 5.3: Observable Indicators of Intraparty Coordination Success and Failure

Table 5.4: Observable Indicators of Interparty Coordination Success and Failure

Table 5.5: Cases (constituencies) and their Fitness to the Selection Criteria

Table 5.6: Selected Constituencies: Winning Candidates \& Parties between 1996 \& 2016

Table 5.7: Logit Analysis of 'Ticket-Splitting' using Survey Data

Table 5.8: Effect of Changing Variables from Their Minimum to Maximum Values on Probability of Ticket Splitting

\section{List of Figures}

Figure 4.1: Percentage of Vote Share and Seat Share for Winning Party 1996 - 2016

Figure 6.1: Percentage of Split Constituencies vs. Disputed Primaries in Parliamentary Elections 1996 - 2016 
Samuel K. Darkwa

\section{List of Appendixes}

Appendix 3.1: Description of the variables

Appendix 3.2: Fieldwork

Survey Cover Letter

Appendix 4.1: Parliamentary Representation in Ghana's Fourth Republic

Appendix 4.2: Coding at the Aggregate Level of Analysis

Appendix 5.1: Coding at the Elite Level of Analysis 


\section{CHAPTER 1. GENERAL INTRODUCTION}

\subsection{INTRODUCTION}

“... the larger point is that the particular mix of mechanisms underlying ticket splitting will evolve as democracies mature." (Helmke 2009, 77).

"Taking ticket splitting in a comparative direction will necessarily expand the definition of ticket splitting commonly used in the American politics literature" (Burden and Helmke 2009, 2)

Split-ticket voting continues to attract research attention in developed as well as emerging democracies due to its effects on democratic representation and accountability (Burden and Helmke 2009; Helmke 2009). This is because the underlying mechanisms of the phenomenon continue to evolve as democracies evolve and this is overwhelmingly prevalent in emerging democracies like Ghana. Aside from the evolution of the underlying mechanisms of the phenomenon, there are discrete nuances in factors that underpin split-ticket voting in different settings though the fundamental cause may be uniform in most settings. As such, the study of ticket splitting needs to expand beyond how it is viewed from the lenses of American and Western European scholars though their work can form the basis of the study. One place where ticket splitting is remarkably pronounced and has fascinated both the electorate and party elites is Ghana.

Political parties usually have strong incentive to encourage straight ticket voting so that voters support all their candidates on the ballot. In Ghana, split-ticket voting is so common that it has a special name, "skirt and blouse voting" denoting a two-piece dress instead of one straight dress (Daddieh 2011). It is associated with voting for a presidential candidate from one political party and for a parliamentary candidate from a different political party in a concurrent election. Not only do we see evidence of split-ticket voting in some constituencies in Ghana, but we also see some evidence that party supporters and elites strategically encourage split-ticket voting under certain conditions ${ }^{2}$. Further, civil society may encourage split-ticket voting to achieve certain 
goals. My dissertation will explore the reasons for this phenomenon and contribute to our understanding of split-ticket voting, elite behavior, and Ghanaian electoral politics.

Given that we see some evidence that party supporters and elites strategically encourage split-ticket voting under certain conditions, it is important to consider different questions when split-ticket voting is studied in Ghana alongside the conventional questions such as: "why will some voters split their tickets, but others will not?" Thus, the following questions become relevant when we study split-ticket voting in Ghana. Why would party elites, or supporters of a political party want either the party's presidential or parliamentary candidate lose the election in a particular constituency? Why would a presidential and or parliamentary candidate of a political party advocate either overtly or covertly for split-ticket voting? Again, why would a supporter, a member, or an official of a political party vote to split the ballot, roll-off the ballot, or abstain? What are the effects of ticket splitting on democratic representation and accountability; is the phenomenon promoting or hurting Ghana's democracy? This dissertation argues that skirt and blouse voting is helping the country's young democracy in two important ways. First, it creates cross-party cohesion especially through strategic moves of party elites from different political parties to form electoral coalition with diverse arrangements to boost their performance which inadvertently further induce ticket splitting. It has been argued that successful democracy is largely the acts of consensually united elites who see politics as bargaining based on the principle of give to get (Best and Higley 2010; Higley and Burton 1989, 2006; Higley et al. 1991). Thus, the strategic moves of political elites through bargaining often create ticket splitting and reduce the incidence of winner-takes-all that often sows the seeds of disaffection among disunited elites which has a potential to cause political instability (Best and Higley 2010; Higley and Burton 1989, 2006; Higley et al. 1991). Second, ticket splitting has direct effect on democratic representation 
and accountability. Here, a voter who is candidate oriented could vote for the most viable candidates irrespective of their party affiliation and in so doing vote based on competence instead of on party identification. This also ensures political accountability in the sense that political actors are challenged to perform or face the wrath of the electorates.

This is not to say that ticket splitting has no adverse consequences on government policies/performance and political accountability. It has been found that ticket splitting can create divided government that can dilute clarity of responsibility among a governing coalition and thus affect government policy formulation and implementation (Burden and Kimball 2009; Powell and Whitten 1993). In this way, the electorates are unable to adequately hold political actors responsible for their performance (Powell and Whitten 1993). Be it as it may, ticket splitting has effects on democratic representation and accountability and it is important to study how elite interactions and voter level factors contribute to it. It worth pointing out that in Ghana, the general impression of the masses is that split-ticketing safeguards the public's interests as politicians cannot condone and connive to engage in misappropriating the nation's scarce resources (Dadzie 2008; Lartey-Adjei 2012). In the study of split-ticket voting, not much attention is typically paid to party elites because the phenomenon is considered voter behavior reflected by individual choice made in the voting booth (Burden and Kimball 2009; Roscoe 2003). However, because the individual choice is a function of more than individual forces, it is imperative to include such factors when evaluating ticket splitting if we want to get to the bottom of the phenomenon. In fact, voter choice (electoral outcome) is influenced by how electoral systems, elite interactions, and alliances affect the choice sets that are available to the electorate (Cox 1997, 1999; Roscoe 2003). Therefore, since voter preference is structured by electoral systems and elite interactions (coordination), this dissertation includes these factors in evaluating ticket splitting and this is 
where the Ghanaian ticket splitting is especially relevant. Studying ticket splitting this way will provide meaningful insights into split-ticket voting in other jurisdictions especially in emerging democracies. Thus, this dissertation will analyze split-ticket voting by considering both voter-level and elite-level factors under a single member first-past-the-post (FPTP) system. It will also explore multiple datasets (large-N surveys from Afrobarometer, aggregate electoral datasets, and fieldwork carried out by the author) to analyze split-ticket voting.

The chapter will first define split-ticket voting and show how the Ghanaian concept is similar and different from the conventional definition. Second, the dissertation will review past research on split-ticket voting. This is critical because, it will help the present study identify what has been done in the subfield and thus, justify the present study based on how it intends to extend our knowledge by building on what others have done thus far. The chapter will distinguish between split-ticket voting and strategic voting and end by providing a brief overview of the dissertation.

\subsection{DEFINITION FOR TICKET SPLITTING}

Burden and Helmke (2009) provide a conceptual framework for ticket splitting that expresses the phenomenon as "a ticket is split if voter $i$ votes for party $j$ in contest $r$ and votes for party $\sim j$ in some other contest" (Burden and Helmke 2009, 2). From this framework, split-ticket voting refers to an aspect of voting behavior where a member of the electorate votes for a candidate of one political party in an election for one office while voting for a candidate of another party in a concurrent election for a different office. For instance, on the same polling day, a voter may vote for a National Democratic Congress (NDC) presidential candidate and for a New Patriotic Party $(\mathrm{NPP})^{3}$ legislative candidate or vice-versa. Thus, ticket splitting occurs when a voter casts at least one vote for a candidate/list representing one party and at least one other vote for a candidate/list representing a different party (or independent). These ballots must be cast at the same election ${ }^{4}$ for 
candidates contesting seats in the same institution (e.g., a legislature using a mixed-member electoral system) or different institutions (e.g. concurrent presidential and parliamentary elections).

Ticket splitting can further be classified into two dimensions (direction and timing). With respect to the direction, the focus is on political institutions (e.g. presidential and parliamentary elections) or the electoral systems involved (e.g. SMD plurality, proportional representation [PR], or mixed-member electoral system). Again, when we speak of ticket splitting in directional terms, we are interested in whether it is vertical (different offices: e.g. presidential and parliamentary) or horizontal (same office but under different electoral systems: e.g. a legislature using a mixedmember electoral system). Conversely, ticket splitting in respect to timing considers whether the phenomenon occurred in concurrent or non-concurrent elections (Campbell and Miller 1957; Burden and Helmke 2009). These classifications are briefly illustrated by Table 1.1 below.

Table 1.1: Ticket Splitting Across Offices and Time.

\begin{tabular}{lll}
\hline & Concurrent & Non-concurrent \\
\hline Horizontal & Mixed member systems elections (Karp et al. & Staggered multi-member \\
& 2002; Burden 1998; Moser and Scheiner 2005) & elections \\
Vertical & Presidential-legislative elections (Brunell and & Midterm and by-elections \\
& Grofman 1998, 2009; Helmke 2009) & (Chandra 2007, 2009) \\
\hline
\end{tabular}

Source: Burden and Helmke (2009, 3)

\subsubsection{Working Definition for Ticket Splitting}

Since the Ghanaian ticket splitting is a vertical-concurrent type located at the lower left quadrant of Table 1.1, I will restrict this study to the Burden and Helmke (2009) definition above and use it as a working definition for this dissertation. In fact, many scholars are of the view that ticket-splitting can only take place in concurrent elections where electorates vote candidates from different political parties into different offices. As such Navia and Saldaña (2015) assert that ticketsplitting can only occur when there is a concurrent election where voters choose candidates for 
different offices. Voters split their tickets when they select a candidate from one party for one office and a candidate from a different party for a different office (Navia and Saldaña 2015, 486; see also Thomson 2007, Watts 2010). It is worth restating that, there are different forms of ticket splitting and these are summarized in Table 1.1 above.

In Ghana, the phrase "skirt and blouse voting" is used to describe two distinct phenomena. The phrase is sometimes used to refer to the type of ticket splitting described above. In its more original usage ${ }^{5}$, however, the phrase refers to an aggregate-level outcome where the winners in the presidential and legislative races in a given constituency (electoral district) come from different political parties (Daddieh 2011; Frempong 2017). In this way, the concept of skirt and blouse voting is different from the conventional concept of split-ticket voting used in political science literature.

Skirt and blouse voting also represents voter behavior in the voting booth which is similar to its conventional usage in mainline political science literature. Scholars have identified two main reasons why skirt and blouse voting occur. First, skirt and blouse voting occur where a voter in the same set of elections chooses a presidential and a parliamentary candidate from different political parties in a concurrent election (Asunka 2016; Ichino and Nathan 2013, 2017; Lindberg 2013; Weghorst and Lindberg 2013). Second, skirt and blouse voting occur in instances where supporters of a political party vote for the party's presidential candidate but vote for a parliamentary candidate from a different political party or an independent candidate (Boafo-Arthur 2006, 2008; Debrah and Gyampo 2013). The difference between the two reasons for electorates voting skirt and blouse is that the first falls within the conventional ticket splitting while the second is an organized act in "isolated" constituencies often characterized by mobilized voter protest due to in-party competition/factions or deliberate sabotage (Daddieh and Bob-Milliar 2012; Debrah 2004). 
Thus, the literature on skirt and blouse voting in Ghana has used the same phrase ("skirt and blouse voting") to mean both split district outcome and split-ticket voting; this creates conceptual ambiguity that requires reclassification to harmonize it with similar concepts used in political science for consistency and comparability. In view of this, the dissertation reclassifies the concept into skirt and blouse voting (split-ticket voting) and skirt and blouse outcome (split district outcome/two office split at the aggregate level). The Ghanaian case triggers questions such as: why would the supporters of a political party defect from their parliamentary candidate in favor of a candidate of another party? Why would they not withdraw from both the presidential and the parliamentary candidates or abstain from the presidential candidate? What is so unique about the presidential candidate and not about the parliamentary candidates? These are questions not asked in ticket splitting literature from other settings and they make the Ghanaian case a unique one.

\subsection{A BRIEF REVIEW OF THE TICKET SPLITTING LITERATURE}

The literature on ticket splitting is voluminous and diverse (Burden and Helmke 2009). For the purpose of this study, the current dissertation will briefly review the most influential work in this chapter and consider it in more detail in chapters 3-5 where it is applied alongside other research. This chapter emphasizes research about demographic and socioeconomic characteristics of voters, strategic policy balancing, divided government, economic voting, candidate quality, and (mis)coordination in ticket splitting.

\subsubsection{Demographic and Socioeconomic Characteristics of Voters}

Most of the literature under this sub-heading is in the US context because the literature in that area is well developed and widely cited. Scholars of elections often approach the study of split-ticket voting by analyzing the demographic and socioeconomic features of voters to find out 
how ticket-splitters differ from other voters (Bybee et al. 1981; Campbell and Miller 1975; Roscoe 2003). Demographically, ticket-splitters are said to be younger, more educated, and often relatively middle-class and white-collar in socioeconomic terms. They tend to live in more suburban areas than the typical middle-class voter (DeVries and Tarrance 1972). Based on such observable indicators of ticket splitters, DeVries and Tarrance (1972) recommend political actors to target such voters with specific campaign messages. In contrast to this work, Campbell and Miller (1957) found no link between ticket splitting and socio-economic characteristics of voters. Other scholars found that the relationship between age and ticket splitting was spurious and there is no statistically significant relationship between education and ticket splitting (Bybee et al. 1981; Roscoe 2003). Thus, there are conflicting findings about the relationship between the demographic features of voters and ticket splitting.

Aside from demographic and socioeconomic features of ticket-splitters, scholars have also considered attitudinal factors of ticket-splitters such as voter perception and political attitudes toward the political parties. It has been found that partisanship intensity and higher interest in politics are inversely related to ticket splitting (Beck et al. 1992; Campbell et al. 1960; Campbell and Miller 1957). In contrast, Maddox and Nimmo (1981) found that while partisans split their ballots, strong partisans tend to split less frequently. This tells us that, under certain circumstances, even strong partisans may split their tickets, and this is one of the puzzles that this dissertation explores. It has also been found that voters who make late voting decisions are more likely to split their tickets (Maddox and Nimmo 1981; Bybee et al. 1981) including those who change their vote intentions based on unfolding issues and those who update their voting intentions over the course of the campaign (Bybee et al. 1981). 
Furthermore, exposure to political information (voter sophistication) especially through print media usage has been found to influence voters to make decisions which positively correlate with ticket splitting (Atwood and Sanders 1975; Bybee et al. 1981; Gomes and Wilson 2006). However, counter evidence has shown that persons who are partisan may be selective in their media choice and as such may not necessarily split their votes. Also, strong partisans who are likely to vote a straight ticket are generally more sophisticated, suggesting that voter sophistication is not a good proxy for ticket splitting (Burden and Kimball 1998, 2009; Roscoe 2003). This dissertation controls for these voter-level factors. It must be pointed out however, that there are conflicting views on the relationship between exposure to political information and ticket splitting. For instance, while some scholars found association between reliance on the print media and ticket splitting (Atwood and Sanders 1975; Bybee et al. 1981), others found no positive relationship between television and ticket splitting (Atwood and Sanders 1975; Beck et al. 1992; Bybee et al. 1981; DeVries and Tarrance 1972).

\subsubsection{Strategic Policy Balancing}

Aside from analyzing how ticket splitters are different from other voters by evaluating the demographic and socioeconomic features of voters, scholars have also examined the phenomenon by considering voter intentions. A classic theory about voter intention is Fiorina's (1988) concept of strategic policy balancing. This concept is derived from a simple proximity spatial model in which voters prefer policies nearest to their ideal points (Downs 1957). It assumes that voters are generally concerned with the overall orientation of the policy implemented by a government and that these voters favor nonextreme policies. It further assumes that political parties hold different positions on the ideological continuum. Due to their preference for nonextreme policies, voters who are positioned at the median segment will be more likely to split their votes to achieve non- 
extreme policies where the parties' policies overlap. Furthermore, the model assumes that voters are rational and are likely to maximize their utilities to obtain optimal policies from casting a splitticket (Fiorina 1988, 1996; Kedar 2005). Thus, voters through their voting decisions are signaling political parties to be less polarized and move towards the ideological center with moderate policies.

Other studies, however, have shown that voters prefer high party polarization because that gives them (voters) distinct choices while ideological or perceived party similarities blur voter choice and so cause ticket splitting (Beck et al. 1992; Petrocik 1991; Petrocik and Doherty 1996; Roscoe 2003). This theory indicates that we should expect the likelihood of ticket splitting to be higher where voters do not see much difference between the parties. We are to expect more splitticket voting where the parties are perceived to be similar because voters do not have distinct choice at the polls.

\subsubsection{Divided Government}

Related to the strategic policy balancing theory is the divided government model. This theory is rooted in Fiorina's $(1988,1992)$ policy balancing model which asserts that a voter's decision to split the ticket is an intentional and conscious choice for divided government. Divided government theory posits that where individual preference overlaps with those of the political parties, that individual will split to achieve moderate policy outcome. Scholars such as Jacobson (1990) and Petrocik (1991) who also view divided government as intentional result of ticket splitting have argued that splitting is a deliberate act of voters to match political parties to institutions the parties have expertise in (institutional matching) or issues they have skills to address (issue ownership). For instance, in the US, it was held that Republicans and Democrats 
had different strengths. Democrats were suitable for Congress because they supported social intervention policies while Republicans were best for the presidency because they were best in managing the economy. Thus, ticket splitting is a purposeful act of voters to place parties in offices they handle best. However, these claims were challenged when in the 1990s Democrats won the presidency to manage the budget deficit while Republicans achieved a Congressional majority (Saad 1995; Roscoe 2003). Other scholars have disputed the assertion that positive attitudes toward divided government are responsible for ticket splitting. These scholars argue that individuals who hold moderate issue positions are no more likely to split than others. They found that divided governments are often accidental than deliberate voter intentions (Burden and Kimball 1998, 2009; Campbell 1960; Erikson 2016; Sigelman et al. 1997; Roscoe 2003).

Scholars studying other countries have different view on ticket splitting and divided government. Ames et al. (2009) observed that Brazilians do not cast their votes with eventual government formation in mind. These scholars argued that Brazil's divided government is inadvertent because voters make separate decisions when voting in presidential and deputy elections. Their main argument is that presidential and deputy elections are "unlinked." Ames et al (2009) are of the view that the sequencing of the elections, such as the mid-term elections in United States, is responsible for divided government (Ames et al 2009; see also Shugart 1995; Shugart and Wattenberg 2001). Other scholars whose research is based in new democracies found ticket splitting in these settings to be akin to voters' intention of protecting themselves by matching experienced politicians and challengers rather than creating a divided government. They argued that voters in new democracies will like to vote for new parties and candidates but would like to avoid making the mistake of having only 'novice' politicians into office. Thus, ticket splitting in these settings is largely electoral insurance rather than divided government (Ames et al 2009; 
Samuel K. Darkwa

Helmke 2009). Hence, studying ticket splitting in new democracies offers profound prospects for expanding our knowledge in split-ticket voting.

\subsubsection{Economic Voting}

Downs' (1957) expected utility theory of voting constitutes the fundamental argument of economic voting theory which posits that a voter would favor a presidential candidate that renders the highest expected utility. Downs's expected utility theory of voting was revised by Fiorina (1981) who argued that voters will vote for an incumbent president whose administration improved citizens' economic conditions and punish an incumbent under whose leadership the economy deteriorated. Further, the revised model asserts that where an incumbent's challenger shows prospects of better performance based on excellent track record, voters are likely to vote for the challenger. Fiorina's (1981) revision, therefore, introduces retrospective and prospective voting into the decision calculus of voters.

In essence, the economic voting model asserts that voters will evaluate the performance of the incumbent and that of the challenger when making their voting decisions. Where a challenger does not have the benefit of office experience, voters are to base their assessment on the prospects of the challenger (Benton 2005; Fiorina 1981; Helmke 2009). Splitting occurs where candidates with higher performance ratings are not from the same party (Fiorina 1981; Lewis-Beck and Paldam 2000; Powell and Whitten 1993). Some scholars argue that the economic voting is not effective because governments were not consistently punished for bad economic times or rewarded for good performance (Anderson 2007). Finally, it has been argued that retrospective voting based on performance is blind especially in situations where voters will like to punish politicians on acts beyond their control such as natural disasters (Achen and Bartels 2004). Furthermore, it has been 
Samuel K. Darkwa

argued that clarity of responsibility (Powell and Whitten 1993), a country's electoral system (Benton 2005) and availability of alternatives (Anderson 2007) may inhibit voters' ability to employ economic voting.

\subsubsection{Candidate Quality}

Scholarship on ticket splitting has also identified candidate-level factors to be responsible for the phenomenon. Three main candidate-level factors identified are: incumbency, campaign spending, and issue positioning (Born 1994; Box-Steffensmeier 1996; Burden and Kimball 2009). It has been observed that incumbency is often associated with candidate quality because incumbents have the advantage of office experience (Born 1994; Burden and Kimball 2009). Consequently, voters whose preferred Congressional candidate does not have the benefit of office experience for instance, will vote for their presidential candidate and either roll-off or vote for a more experienced candidate who is often the incumbent (Born 1994; Burden and Kimball 2009). On the contrary, it has also been found that incumbency may not always be advantage and that it can also be a liability (Burden 2009; Roscoe 2003; Scheiner 2005). Campaign spending has also been found to influence ticket splitting in some settings such that a candidate who is able to spend beyond certain threshold has a greater chance of getting the attention of the electorate and therefore can cause ticket splitting (Burden and Kimball 1998, 2009; Roscoe 2003). Though campaign spending can cause splitting, those who spend more sometimes lose the election to their lowerspending counterparts (Frempong 2017; Roscoe 2003).

Finally, a candidate's issue positioning has been found to be responsible for ticket splitting. Advocates of issue positions argue that candidates who move closer to their opponent's issue position or move away from their party's position can create ticket splitting (Frymer 1994; Key 
1966; Petrocik and Doherty 1996). It has been argued that high party polarization decreases splitting while less polarization increases splitting (Beck et al. 1992; Petrocik 1991; Petrocik and Doherty 1996; Roscoe 2003). Thus, when there is a clear difference between the parties or candidates contesting the elections, voters can make distinct choices but where the contestants look alike on ideological grounds and issue positions, voters do not have unique choice, therefore, they will split their votes (Key, 1966). In fact, scholars have found a strong statistical association between candidates' issue positions and ticket splitting (Burden and Kimball 2009). Hence, all things being equal, where candidates position on issues are not very diverse, we expect higher likelihood of splitting. The logic of candidate quality and ticket splitting is that, where the most visible candidates in the different races belong to different parties, the greater the likelihood of ticket splitting.

\subsection{6 (Mis)coordination Ticket Splitting}

Cox $(1997,1999)$ provides a model to understand how party elites make their entry decisions. This model is related to the concept that he referred to as the $M+1$ rule (strategic entry rule required of party elites), where $M$ refers to the district magnitude. This model suggests that where a voting district (constituency) elects one candidate, the viable number of candidates in that constituency is two (that is the district magnitude plus one). Where elites field more than two candidates in that constituency, voters who care only about the present election and want their votes to count, will withdraw support from less viable candidates. For instance, a voter whose preferred candidate is the third-ranked candidate will rather prefer to vote for one of the top two candidates than for the third-ranked candidate. Consequently, the contest in SMD plurality is often reduced to a competition between the most viable candidates. In this way, SMDs with plurality rule favor two party systems. However, proportional representation (PR) systems are less 
punishing to small parties because the district magnitude is greater than " 1 " and tend to produce less strategic defection (Duverger 1954). Thus, a voter whose preferred choice is the third-ranked candidate (or party) will still vote for that candidate and still be able to influence the system. As a result, PR systems tend to produce multiparty competition.

Consequently, some scholars are of the view that mixed-member electoral systems that combine SMD plurality and PR will have a mixture of the two systems. This is because competition at the SMD tier will reduce to a two-party affair while the PR tier will produce multiparty competition (Milazzo, Moser, and Scheiner 2018; Moser and Scheiner 2005, 2012; Rich 2014). However, proponents of contamination effects argue that the use of different electoral rules in the same voting district would yield a vote bonus at the PR tier for parties who contest elections at the SMD tier (Ferrara, Herron, and Nishikawa 2005; Guinjoan 2016; Herron and Nishikawa 2001). Therefore, the overlap of electoral arenas in mixed electoral systems will encourage multiparty competition at the SMD tier contrary to what takes place in a pure SMD system.

The major takeaway from (mis)coordination ticket splitting is that in pure SMDs, when party elites fail to coordinate their entry given by the first $M+1$ rule, voters will activate the second $M+1$ rule by concentrating their votes on the most viable candidates. It means that where a political party fields more than one candidate either due to nomination problems or factions, voters are likely to withdraw (split away) from that party. This is because the support base of that party may divide and voters who do not want to waste their votes will support their next preferred candidate who is likely to win. In the same vein, where an ideological bloc, for instance, leftist parties, field more than one candidate in a pure SMD, that bloc may be (mis)coordinating their entry. If their opponent commands similar support, voters are likely to defect from at least one of the candidates from the leftist bloc. It is worth stressing that voter coordination ultimately occurs at the polls 
where voters defect from nonviable contestants. In the case of Ghana, where elections are conducted in concurrent presidential-legislative races in SMDs, voter coordination can lead to ticket splitting if the candidates a voter elects in the two races are not from the same political party (Beck et al. 1992; Burden and Kimball 2009). Thus, if a party wants to avoid influencing voters to split their tickets, it must coordinate on competitive candidates in both presidential and parliamentary races and ensure that there is harmony between the presidential and parliamentary candidates' campaigning/marketing.

\subsection{DISTINCTION BETWEEN SPLIT-TICKET VOTING AND STRATEGIC VOTING}

Conceptually, strategic voting deals with voters' strategic response or reaction to electoral rules with the view of making their votes count (Batto et al. 2016; Bawn 1999; Cox 1997; Roberts 1988). In mixed systems for instance, supporters of dominant parties normally tend to vote sincerely for their most preferred candidates/parties in both the SMD and PR tiers because their preferred candidates/parties are often viable, therefore, they do not necessarily need to vote strategically. In contrast, supporters of minor parties tend to act strategically especially in district races by voting for the viable candidates of major parties closer to their ideologies but vote sincerely at the PR tier for their preferred candidates/minor parties. Aside the electoral rules determining the strategic acts of the electorates, the strategic moves of party elites to coordinate candidate nomination in district races with other parties often influence the strategic acts of the electorates. These strategic moves of elites often determine the electoral context. By electoral context, I mean the parties and candidates contesting in a particular district as well as the competitiveness of the election. Proponents of contamination effects argue that party elites can lessen the strategic acts of voters by fielding candidates in SMDs in order to boost party votes in the PR tier (Cox and Schoppa 2002; Ferrara and Herron 2005; Ferrara, Herron, and Nishikawa 
2005; Herron and Nishikawa 2001). Thus, voters may have their preferred candidates or party identification, the electoral rule and the electoral context may influence their voting decision. In sum, strategic voting occurs where voters react to the electoral rules and context and regulate their vote choices to ensure that their votes count (do not waste their votes) especially where their most preferred candidates/parties are not viable.

Split-ticket voting occurs where voters cross party lines when choosing their representatives (Gschwend et al. 2003; Johnston and Pattie 2003; Karp et al. 2002). It is voting for different political parties into different political institutions such as presidency and legislature vertical splitting or for different parties into the same office but under different electoral systems e.g. a legislature using a mixed-member electoral system - horizontal splitting (Burden and Helmke 2009; Campbell and Miller 1957). Conceptually, two main viewpoints have been advanced to explain the patterns of split-ticket voting and these are whether voters are acting sincerely or strategically (Plescia 2016, 5). It has been argued that voters deliberately split to achieve divided government (Alesina and Rosenthal 1995; Fiorina 1992) or as an insurance for having both experienced politicians and new parties/candidates in office (Ames et al 2009; Helmke 2009). However, scholars such as Alvarez and Schousen (1993), Beck et al. (1992) and Mattei and Howes (2000) do not find support for strategic incentives for ticket splitting. Proponents of sincere ticket splitting argue that voters split their votes where the viable candidates in the different races are not from the same political party and voters want to sincerely vote for the viable candidates/parties (Burden and Kimball 2009; Roscoe 2003).

It worth pointing out, however, that strategic voting and split-ticket voting are two different concepts though they may overlap. As explained above, strategic voting occurs where voters want their votes to count by adjusting their voting preference in response to electoral rules and elite 
strategic moves. These strategic acts of voters may result in split ticket or straight ticket when the party affiliation of candidates selected in the different races are considered. In the case of ticket splitting, the candidates selected by a voter in the different races are not from the same party while in the case of straight ticket, the candidates selected in both races are from the same party. In mixed-member electoral systems, split-ticket voting tends to be strategic especially if a voter's preferred party/candidate has no chance of winning (Bawn 1999; Karp et al. 2002; Plescia 2016). Normally, it is the supporters of minor parties who often engage in this strategic behavior by casting a sincere vote at the PR tier and voting strategically at the SMD tier by defecting from unviable candidates which at times leads to ticket splitting. Supporters of major parties on the other hand, are more likely to cast straight tickets because they often field viable candidates. Thus, the convention is that voters vote sincerely at the PR tier and often strategically at the SMD tier and that there is no ticket splitting at the PR tier. However, it has been found that though at the PR tier there is no ticket splitting, supporters of major parties may at times split strategically to help their junior coalition partners cross the electoral threshold (Abramson et al. 2010; Gschwend 2007; Hobolt and Karp 2010). Finally, though straight ticket voting is often viewed as a sign of sincere voting, it could be strategic in instances where a supporter of a minor party decides to cast a strategic straight ticket ballot for a major party where the voter's party has no chance of winning a seat (Plescia 2016). In sum, strategic voting and ticket splitting are two different concepts however, strategic voting can create ticket splitting where a voter's strategic acts result in the selection of candidates from different political parties at the different races or tiers. Also, a supporter of a minor party may adopt strategic straight ticket voting for a major party where his or her preferred party has no chance of winning a seat. 
Samuel K. Darkwa

\subsection{GENERAL OVERVIEW OF THE DISSERTATION}

This dissertation is interested in ticket splitting and explores the subject largely from how coordination especially on the part of party elites influences the phenomenon. The conventional literature on the subject has largely approached the subject from voter perspective (Bybee et al. 1981; Campbell et al. 1960; Campbell and Miller 1957). The current dissertation would like to incorporate elite level factors which are coordination centered to analyze split-ticket voting where Ghana presents appropriate context. The rest of the dissertation is organized as follows:

Chapter 2 discusses the theory of strategic coordination which is based on Cox's (1997, 1999) strategic coordination theory introduced in the preceding section 1.3.6 above. The strategic coordination theory is the primary framework adopted by this dissertation to evaluate the concept of ticket splitting. The chapter breaks the theory into intraparty and interparty coordination successes and failures, discusses the features of each of these, as well as the strengths and weaknesses of the theory. It shows why the theory is appropriate for the Ghanaian case.

The analysis which begins in Chapter 3 examines individual-level factors and elite-level factors (intraparty and interparty variables) of ticket splitting. Using Afrobarometer Round 6 datasets, the chapter focuses its analysis on variables that have significant connection with ticket splitting. The analysis helps to examine both individual level factors and elites level factors in a single model to identify which have utility when it comes to explaining ticket splitting.

Chapter 4 employs an aggregate-level electoral dataset (1996-2016) from Electoral Passport $^{6}$ to analyze the district-level aspect of the skirt and blouse outcome. Chapter 5 focuses on data from fieldwork carried out in Ghana that samples 303 party elites. This allows the dissertation to test coordination theory in more detail. It controls for important variables that are likely to 
impact splitting by considering alternative explanations such as voter demographic variables, political attitude and political information. By utilizing multiple datasets, the dissertation provides more reliable evidence for conclusions arrived at in this study.

Finally, Chapter 6 summarizes the findings from the research and highlights the dissertations' contribution to the split-ticket voting literature. The chapter also discusses the limitations of the research and provides recommendations for future research in the subfield.

\subsection{REFERENCES}

Abramson, Paul R., et al. 2010. "Comparing strategic voting under FPTP and PR." Comparative Political Studies 43.1: 61-90.

Achen, Christopher H., and Larry M. Bartels. 2004. "Blind Retrospection: Electoral Responses to Drought, Flu, and Shark Attacks." Working Paper, Princeton University

Alesina, Alberto, and Howard Rosenthal. 1995. Partisan Politics, Divided Government, and the Economy. Cambridge University Press.

Alvarez, R. Michael, and Matthew M. Schousen. 1993. "Policy moderation or conflicting expectations? Testing the intentional models of split-ticket voting." American Politics Quarterly 21.4: 410-438.

Ames, Barry, Andy Baker, and Lucio R. Renno. 2009. "Split-ticket Voting as the Rule: Voters and Permanent Divided Government in Brazil.” Electoral Studies 28.1: 8-20.

Anderson, Christopher J. 2007. "The End of Economic Voting? Contingency Dilemmas and the Limits of Democratic Accountability." Annual Review of Political Science 10. 271-96.

Asunka, Joseph. 2016. "Partisanship and Political Accountability in New Democracies: Explaining Compliance with Formal Rules and Procedures in Ghana." Research \& Politics 3.1.

Atwood, L. Erwin, and Keith R. Sanders. 1975. "Perception of Information Sources and Likelihood of Split-Ticket Voting.” Journalism Quarterly 52.3: 421-428.

Batto, Nathan F., et al. 2016. Mixed-Member Electoral Systems in Constitutional Context. University of Michigan Press.

Bawn, Kathleen. 1999. "Voter Responses to Electoral Complexity: Ticket Splitting, Rational Voters and Representation in the Federal Republic of Germany." British Journal of Political Science 29.3: 487-505.

Beck, Paul Allen, Lawrence Baum, Aage R. Clausen, and Charles E. Smith, Jr. 1992. "Patterns and Sources of Ticket Splitting in Subpresidential Voting." American Political Science Review 86:916-28. 
Benton, Allyson Lucinda. 2005. "Dissatisfied Democrats or Retrospective Voters? Economic Hardship, Democratic Accountability." Annual Review of Political Science 10: 271-96.

Best, Heinrich, and John Higley. 2010. Democratic Elitism: New theoretical and Comparative Perspectives. Brill.

Boafo-Arthur, Kwame. 2006. "The 2004 General Elections: An Overview”, In Boafo-Arthur, ed., Voting for Democracy in Ghana: The 2004 Elections in Perspective, Vol. 1. Accra: Freedom Publications, pp. 33-58.

Boafo-Arthur, Kwame. 2008. Democracy and Stability in West Africa: the Ghanaian Experience. Nordiska Afrikainstitutet; Department of Peace and Conflict Research, Uppsala University.

Born, Richard. 1994. "Split-ticket Voters, Divided Government, and Fiorina's Policy-Balancing Model.” Legislative Studies Quarterly. 95-115.

Box-Steffensmeier, Janet M. 1996. "A Dynamic Analysis of the Role of War Chests in Campaign Strategy." American Journal of Political Science. 352-371.

Brunell, Thomas L., and Bernard Grofman. 1998. "Explaining Divided US Senate Delegations, 1788-1996: A Realignment Approach.” American Political Science Review 92.2: 391-399.

Brunell, Thomas L., and Bernard Grofman. 2009. "Testing Sincere Versus Strategic Split-Ticket Voting at the Aggregate Level: Evidence from Split House-President Outcomes, 1900-2004." Electoral Studies 28.1: 62-69.

Burden, Barry C. 1998. "Chronology of the 1996 Presidential Campaign.” In Herbert F. Weisberg and Janet M. Box-Steffensmeier (eds.) Reelection 1996: How Americans Voted, ed. Chatham, NJ: Chatham House Publishers

Burden, Barry C., and David C. Kimball. 1998. "A New Approach to the Study of Ticket Splitting." American Political Science Review 92:533-44.

Burden, Barry C., and David C. Kimball. 2009. Why Americans split their tickets: Campaigns, competition, and divided government. University of Michigan Press.

Burden, Barry C., and Gretchen Helmke. 2009. "The Comparative Study of Split-Ticket Voting." Electoral Studies 28.1: 1-7.

Bybee, Carl R., et al. 1981. "Mass Communication and Voter Volatility." Public Opinion Quarterly 45.1: 69-90.

Campbell, Angus, and Warren E. Miller. 1957. "The motivational basis of straight and Split-Ticket Voting." American Political Science Review 51.2: 293-312.

Campbell, Angus, Philip E. Converse, Warren E. Miller, and E. Donald. 1960. The American Voter University of Chicago Press

Chandra, Kanchan. 2007. Why Ethnic Parties Succeed: Patronage and Ethnic Head Counts in India. Cambridge University Press, 2007.

Chandra, Kanchan. 2009. "Why Voters in Patronage Democracies Split their Tickets: Strategic Voting for Ethnic Parties.” Electoral Studies 28.1: 21-32. 
Cox, Gary W. 1997. Making Votes Count: Strategic Coordination in the World's Electoral Systems. Cambridge University Press.

Cox, Gary W. 1999. "Electoral rules and electoral coordination." Annual Review of Political Science 2.1: 145-161.

Cox, Karen E., and Leonard J. Schoppa. 2002. "Interaction Effects in Mixed- Member Electoral Systems: Theory and Evidence from Germany, Japan, and Italy." Comparative Political Studies 35 (9): 1027- 53.

Daddieh, Cyril K., and George M. Bob-Milliar. 2012. "In Search of 'Honorable' Membership: Parliamentary Primaries and Candidate Selection in Ghana." Journal of Asian and African Studies 47.2: 204-220.

Daddieh, Cyril. 2011. "Democratic Consolidation Without a Second Turnover: Ghana's Remarkable 2004 Elections." In Abdoulaye Saine, Boubacar N'Diaye, and Mathurin Houngnikpo (eds.) Elections and Democratization in West Africa 1990-2009. Trenton, New Jersey: Africa World Press

Dadzie, Ato Kwamena. 2008. "Let's vote 'skirt and blouse", Ghanaweb.com Retrieved on July 8, 2019, from https://www.ghanaweb.com/GhanaHomePage/features/Let-s-vote-skirt-and-blouse$\underline{154036}$

De Vries, Walter, and V. Lance Tarrance. 1972. The Ticket-Splitter: A New Force in American Politics. Grand Rapids: Eerdmans.

Debrah, Emmanuel, and Ransford Edward Van Gyampo. 2013. "The Youth and Party Manifestos in Ghanaian Politics-The Case of the 2012 General Elections." Journal of African Elections 12.2: 96-114.

Debrah, Emmanuel. 2004. "The politics of elections: opposition and incumbency in Ghana's 2000 elections." Africa Insight 34.2-3: 3-15.

Downs, Anthony. 1957. An Economic Theory of Democracy. New York: Addison Wesley.

Duverger, Maurice. 1954. Political Parties: Their Organization and Activity in The Modern State. London: Methuen.

Erikson, Robert S. 2016. "Congressional Elections in Presidential Years: Presidential Coattails and Strategic Voting." Legislative Studies Quarterly.

Ferrara, Federico, Erik Herron, and Misa Nishikawa. 2005. Mixed Electoral Systems: Contamination and its Consequences. Springer.

Fiorina, Morris P. 1981. Retrospective Voting in American National Elections. Yale University Press.

Fiorina, Morris P. 1988. "The Reagan Years: Turning Toward the Right or Groping Toward the Middle?" In Barry Cooper, Allan Komberg, and William Mishler (eds.) The Resurgence of Conservatism in Anglo-American Democracies. Durham, NC: Duke University Press. 
Fiorina, Morris P. 1992. "An Era of Divided Government." Developments in American politics. Palgrave, London. 324-354.

Fiorina, Morris P. 1996. Divided Government, Second Ed. Allyn \& Bacon, Needham Heights, MA.

Frempong, Alexander Kaakyire Duku. 2017. Elections in Ghana: 1951 - 2016. Digibooks Ghana Ltd.

Frymer, Paul. 1994. “Ideological Consensus Within Divided Party Government.” Political Science Quarterly 109.2: 287-311.

Gschwend, Thomas, Ron Johnston, and Charles Pattie. 2003. "Split-ticket Patterns in MixedMember Proportional Election Systems: Estimates and Analyses of their Spatial Variation at the German Federal Election, 1998.” British Journal of Political Science 33.1: 109-127.

Guinjoan, Marc. 2016. Parties, Elections and Electoral Contests: Competition and Contamination Effects. Routledge.

Helmke, Gretchen. 2009. "Ticket-Splitting as Electoral Insurance: The Mexico 2000 Elections." Electoral Studies 28.1: 70-78.

Herron, Erik S., and Misa Nishikawa. 2001. "Contamination Effects and the Number of Parties in Mixed-Superposition Electoral Systems.” Electoral Studies 20.1: 63-86.

Higley, John, and Michael Burton. 2006. Elite foundations of liberal democracy. Rowman \& Littlefield Publishers.

Higley, John, and Michael G. Burton. 1989. "The elite variable in democratic transitions and breakdowns." American sociological review: 17-32.

Higley, John, et al. 1991. "Elite integration in stable democracies: a reconsideration." European Sociological Review 7.1: 35-53.

Hobolt, Sara B., and Jeffrey A. Karp. 2010. "Voters and coalition governments." Electoral Studies 29.3: 299-307.

Ichino, Nahomi, and Noah L. Nathan. 2013. "Do Primaries Improve Electoral Performance? Clientelism and Intra-Party Conflict in Ghana." American Journal of Political Science 57.2: 428441.

Ichino, Nahomi, and Noah L. Nathan. 2017. "Primary Elections in New Democracies: The Evolution of Candidate Selection Methods in Ghana."

Jacobson, Gary C. 1990. The Electoral Origins of Divided Government: Competition in US House Elections, 1946-1988. Westview Press.

Johnston, Ron, and Charles Pattie. 2003. "Evaluating an Entropy-Maximizing Solution to the Ecological Inference Problem: Split-Ticket Voting in New Zealand, 1999." Geographical Analysis 35.1: $1-23$.

Karp, Jeffrey A. 2009. "Candidate Effects and Spill-Over in Mixed Systems: Evidence from New Zealand." Electoral Studies 28.1: 41-50. 
Karp, Jeffrey A., et al. 2002. "Strategic Voting, Party Activity, and Candidate Effects: Testing Explanations for Split Voting in New Zealand's New Mixed System.” Electoral Studies 21.1: 122.

Kedar, Orit, 2005. "When Moderate Voters Prefer Extreme Parties: Policy Balancing in Parliamentary Elections.” American Political Science Review 99, 185-199.

Key, Valdimer Orlando, and Milton Curtis Cummings. 1966. The Responsible Electorate: Rationality in Presidential Voting, 1936-1960, [by] VO Key, with the Assistance of Milton C. Cummings; Foreword by Arthur Maass. Harvard University Press.

Lartey-Adjei Festus. 2012. "Be Bold; vote skirt and blouse!" Ghanaweb.com Retrieved on July 8, 2019, from https://www.ghanaweb.com/GhanaHomePage/NewsArchive/Be-Bold-vote-skirt-andblouse-Sakara-258747

Lewis-Beck, Michael S., and Martin Paldam. 2000. "Economic Voting: An Introduction." Electoral Studies 19: 113-121.

Lindberg, Staffan I. 2013. "Have the Cake and Eat It: The Rational Voter in Africa." Party Politics 19.6: $945-961$.

Maddox, William S., and Dan Nimmo. 1981. "In Search of the Ticket Splitter." Social Science Quarterly 62.3: 401.

Mattei, Franco, and John S. Howes. 2000. "Competing explanations of split-ticket voting in American national elections.” American Politics Quarterly 28.3: 379-407.

Milazzo, Caitlin, Robert G. Moser, and Ethan Scheiner. 2018. "Social Diversity Affects the Number of Parties Even Under First-Past-the-Post Rules.” Comparative Political Studies 51.7: 938-974.

Moser, Robert G., and Ethan Scheiner. 2005. Strategic Ticket-Splitting and the Personal Vote in Mixed-Member Electoral Systems." Legislative Studies Quarterly 30.2: 259-276.

Moser, Robert G., and Ethan Scheiner. 2012. Electoral Systems and Political Context: How the Effects of Rules Vary Across New and Established Democracies. Cambridge University Press, 2012.

Navia, Patricio, and José Luis Saldaña. 2015. "Mis-Coordination and Political Misalignments in Ticket-Splitting: The Case of Chile, 2005-2009. "Contemporary Politics 21.4: 485-503.

Petrocik, John R. 1991 "Divided Government: Is it All in the Campaigns?” The politics of Divided Government: 13-38.

Petrocik, John R., and Joseph Doherty. 1996. "The Road to Divided Government: Paved without Intention." In Peter F. Galderisi (ed.) Divided Government: Change, Uncertainty, and the Constitutional Order. Lanham, MD: Rowman and Littlefield.

Plescia, Carolina. Split-ticket voting in mixed-member electoral systems: a theoretical and methodological investigation. Colchester: Ecpr Press, 2016.

Powell, G. Bingham and Guy D. Whitten. 1993. "A Cross-National Analysis of Economic Voting: Taking Account of the Political Context." American Journal of Political Science 37:391-414. 
Rich, Timothy S. 2014. "Split-Ticket Voting in South Korea's 2012 National Assembly Election". Asian Politics \& Policy-Volume 6, Number 3-Pages 455-469

Roberts, Geoffrey K. 1988. “The 'Second- Vote' Campaign Strategy of the West German Free Democratic Party.” European Journal of Political Research 16:317- 37.

Roscoe, Douglas D. 2003. "The Choosers or the Choices? Voter Characteristics and the Structure of Electoral Competition as Explanations for Ticket Splitting." Journal of Politics 65.4: 11471164.

Saad, Lydia. 1995. "Budget Standoff Not Welcomed by Most Americans.” Gallup Poll Monthly 362: 5-7.

Scheiner, Ethan, 2005. Democracy with Competition in Japan: Opposition Failure in a One-Party Dominant State. Cambridge University Press, New York.

Shugart, Matthew Soberg. 1995. "The Electoral Cycle and Institutional Sources of Divided Presidential Government.” American Political Science Review 89.2: 327-343.

Shugart, Matthew, and Martin P. Wattenberg. 2001. Mixed-Member Electoral Systems: The Best of Both Worlds? Oxford University Press.

Sigelman, Lee, Paul J. Wahlbeck, and Emmett H. Buell Jr. 1997. "Vote Choice and the Preference for Divided Government: Lessons of 1992.” American Journal of Political Science: 879-894.

Thomson, Alex. 2007. Glossary of US Politics and Government. Edinburgh, GBR: Edinburgh University Press.

Watts, Duncan. 2010. Dictionary of American Government and Politics. Edinburgh, GBR: Edinburgh University Press.

Weghorst, Keith R., and Staffan I. Lindberg. 2013. "What Drives the Swing Voter in Africa?" American Journal of Political Science 57.3: 717-734.

\subsection{NOTES:}

1. Constituencies with skirt and blouse outcome in 2012 http://citifmonline.com/2016/11/14/constituencies-that-voted-skirt-and-blouse-in-2012infographic/

2. 'Skirt and blouse' voting in Ghana. The trend, winners and losers https://www.graphic.com.gh/news/politics/skirt-and-blouse-voting-in-ghana-the-trend-winnersand-losers.html

3. NPP and NDC are the two dominant parties in Ghana. Together, their vote share is over $97 \%$ (Boafo-Arthur 2006; Frempong 2017)

4. There are other types of ticket splitting in non-concurrent elections (e.g. midterm election in the US) where the electorates may vote to moderate the effects of their choice in the presidential 


\section{Samuel K. Darkwa}

election by voting another party in the midterm legislative elections (Burden and Helmke 2009, 2; see also Alesina and Rosenthal, 1995; Fiorina, 1996).

5. The phrase "skirt and blouse voting" was first coined in Ghana where in a party's strongholds the party's national executives decided to impose parliamentary candidates as the "consensus candidates" instead of electing the candidates in the party's primaries and aggrieved nomination seekers massed up support to vote against the so called "consensus candidates". The campaign message of the aggrieved nomination seekers was to elect the party's presidential candidate but vote to cause the defeat of the "consensus candidates". Thus, the original idea was not about the individual act of ticket splitting but to produce an electoral outcome where the party's presidential candidate is elected and the "consensus candidates" lose the election in those constituencies (Frempong 2017). Since then both constituency split result and the individual act of ticket splitting is referred to in Ghana as skirt and blouse voting. No attempt has been made to reclassify the two usages of the concept per the literature I have sighted so far from Ghana though I follow the publication of leading Ghanaian electoral scholars.

\section{Electoral Passport http://www.electionpassport.com/}


Samuel K. Darkwa

\section{CHAPTER 2. DEVELOPING A CONCEPTUAL FRAMEWORK}

\subsection{INTRODUCTION}

This dissertation explores split-ticket voting. Instead of examining the subject exclusively from voter-level factors responsible for split-ticket voting, it evaluates the puzzle from both elitelevel and voter-level factors. This is because the individual choice made in the voting booth is a function of more than individual forces (Cox 1997, 1999; Roscoe 2003). As a result, the chapter develops a conceptual framework that can suitably address both voter-level and elite-level factors in a more cohesive and reliable way. Furthermore, the selected framework must aptly handle the subject using multiple levels of analysis. ${ }^{1}$ Since it is often valuable to utilize multiple levels of analysis in studying a phenomenon (Kollman 2018), a theoretical framework capable of handling multiple datasets such as survey data, aggregate electoral data, and fieldwork offers an added advantage of complementary and richer analysis when the same problem is viewed from various levels. Given these objectives, the dissertation finds Cox's (1997, 1999) strategic coordination theory represented by the two $M+1$ rules to be a suitable framework capable of handling voterand elite-level factors.

In what follows, the chapter discusses strategic coordination theory which is the main theoretical framework adopted by this dissertation to explore the phenomenon of split-ticket voting in Ghana. It shows how the theory is suitable for handling both voter-level and elite-level factors of ticket splitting. Next, the chapter puzzles out the two dimensions of the elite level factors of the theory: intraparty and interparty coordination successes and failures. The penultimate section discusses the strengths and weaknesses of the theory and shows where it is applicable to explain the phenomenon of ticket splitting and where it breaks down and therefore, fails to explain split- 
Samuel K. Darkwa

ticket voting. The final section shows why Ghana presents the appropriate kind of context to explore the coordination theory to investigate ticket splitting in new democracies.

\subsection{STRATEGIC COORDINATION THEORY}

While the literature reviewed in Chapter 1 above identifies several factors that correlate with split-ticket voting, there has been no comprehensive conceptual framework that captures how both voter and elite level factors interconnect to explain the phenomenon. Cox's $(1997,1999)$ strategic coordination theory which is based on Duverger's observation of how electoral systems affect the structure of electoral competition seem to give us an idea of how both voter and elite level factors interconnect to explain strategic voting which has a potential of helping our understanding of ticket splitting emerging from the strategic acts of voters and political elites. Duverger observed that electoral systems have specific logical effects on the structures of electoral competition on voters and competitors. Electoral systems that adopt plurality rule tend to lead to a two-party system while systems with majority runoff tend to lead to multiparty competition (Duverger 1954, 1959). According to Duverger, the mechanical and psychological effects of the electoral rules influence the structure of electoral competition. The mechanical effect has to do with the process of how vote distribution is transformed into seat allocation. The term 'mechanical effect' emerges from how the strict application of electoral laws affects seat share. The psychological effect is how voters and political actors structure their behavior in anticipation of the mechanical effect. Thus, the term 'psychological effect' is the influence the mechanical effects have on voters and political elites.

According to Cox $(1997,1999)$ the mechanical and psychological effects structure the electoral competition differently in different systems. For instance, in single member first-past- 
the-post (FPTP) system (SMDs) where a single candidate is elected under a plurality rule, voters tend to concentrate their votes on the top two contenders. As a result, competitions in SMD systems with plurality rules tend to favor two-party systems. However, in PR systems where more than one candidate is elected, the system is less punishing and therefore, favors multiparty competition. With this, Cox provided a formula (logical expression) to capture how the mechanical and psychological effects structure the electoral competition differently in different electoral systems. In his view, because the mechanical effect relates to the process by which a distribution of votes is transformed into a distribution of seats within a district, it is important to consider the number of seats in that district (district magnitude) in arriving at that logical expression. The expression should also hold for political actors and voters who are influenced by the mechanical effects of the electoral rule to adjust their behavior to make votes count (Cox 1997). This logical expression is given by $M+1$ where $M$ refers to the district magnitude. This expression has come to be known as the $M+1$ rule. According to Cox $(1997,1999)$, there are two $M+1$ rules; the first relates to the entry strategy required of party elites while the second $M+1$ rule applies to the strategic acts required of voters. Cox (1997) contends that if political elites (parties and candidates) are to make votes count (reap the benefits in investing in parties and candidates), they are to adopt strategic entry while voters need to adopt strategic voting behavior. In this way, party elites are to coordinate their entry strategy on two candidates in SMDs where just one seat is allocated. If parties failed to coordinate on two candidates in SMDs, voters will have to concentrate their votes on the top two contenders for their votes to count. As a result, with time, electoral competition in SMDs will be reduced to a two-party affair while competition in PR systems will lead to multiparty system. It must be pointed out however, that empirical evidence shows that the $M+1$ rule does not necessarily 
lead to two-party competition in all countries as demonstrated by countries such as Canada, India, and the United Kingdom (Ferrara, Herron, and Nishikawa 2005; Herron and Nishikawa 2001).

Though voters are influenced to act strategically to make their votes count, they could do so based on how much the electoral system/electoral rules and elite interaction will allow them. These two can influence the strategic behavior of the voter. That is, they can cause the voter to either cast strategic or sincere vote. They can also help us to find out the type of ballot the voter casts, whether straight ticket or split ticket. Strategic voting explains how voters adjust their choices for their votes to count. In pure PR systems, voters do not have to vote strategically for their votes to count because the district magnitude is greater than one however, in SMDs, because the district magnitude is one, they have to act strategically. In mixed systems, voters can still vote sincerely at the PR tier and strategically at the SMD tier. The parties selected at the different tiers will show whether the voter voted straight ticket or split ticket. The type of party a voter supports, or elite interactions can influence the strategic acts of the voter. For instance, supporters of dominant parties tend to vote sincerely for their most preferred parties in both the SMD and PR tiers because their preferred parties are often viable. As such they do not necessarily need to vote strategically. This creates straight ticket voting. In contrast, supporters of minor parties tend to act strategically especially in district races by voting for the viable candidates of major parties closer to their ideologies but vote sincerely at the PR tier for their preferred minor parties leading to ticket splitting. These acts can cause ticket splitting or straight ticketing.

Again, in mixed systems, due to the overlap of the electoral system, elites are incentivized to field candidates in SMD tier to create vote bonus in the PR tier which can cause voters to vote for the same party at both tiers thereby reducing strategic voting. This act of parties reduces ticket splitting in the sense that voters are motivated to cast straight ticket. This is what is referred to as 
contamination effect (Ferrara and Herron 2005; Ferrara, Herron, and Nishikawa 2005; Herron and Nishikawa 2001). It has also been found that though at the PR tier there is no ticket splitting, major parties who enter into alliance can cause their supporters to at times split strategically to help their junior coalition partners cross the electoral threshold (Abramson et al. 2010; Gschwend 2007; Hobolt and Karp 2010). Again, where parties do not field candidates in all districts or do not contest in all races, their supporters are forced to split their ticket in order to make their votes count (Benoit et al. 2006; Thrasher et al. 2014). Again, in concurrent legislative and presidential elections, parties can field candidates in legislative or presidential constituencies that they are not comparatively strong to boost their votes in constituencies that they are comparatively strong. This can create ticket splitting or split outcomes. It must be pointed out however, that not all voters may vote strategically because voters may select non-viable candidates for all sorts of reasons. Again, strategic voting and ticket splitting are two different concepts, strategic voting can create ticket splitting where a voter's strategic acts causes the selection of candidates from different political parties at the different races or tiers. Again, though voters may act strategically, their acts are constrained by the electoral context which is structured by elite moves and electoral rules. Therefore, the decision to split tickets may depend on the available legislative and presidential choice set, coordination among parties (such as deals, joint nominations, etc.), as well as signaling among party elites.

\subsubsection{Intraparty Coordination Successes and Failures}

As stated above, the first $M+1$ rule, the strategic entry decision of party elites, is applicable to party elites in the same party, those in the same ideological bloc, and from different ideological blocs. When coordination involves elites from the same political party, it is referred to as intraparty coordination. Here, party elites are to limit nomination to ensure that a single candidate emerges 
as the representative of the party to contest the election under the party brand (Benoit 2001; Cox 1997, 1999, 2006; Golder 2006). The way of limiting nomination requires that elites harmonize their actions and use democratic and transparent means that are acceptable to most people (Benoit 2001; Cox 1999; Golder 2006). When this happens, party members and their supporters will have no incentive to coordinate their votes leading to possible ticket splitting in the main election. In this way, intraparty coordination success is more likely to reduce ticket splitting. That is, party supporters are less likely to split where there is intraparty coordination success.

However, where the nomination process is not democratic and transparent, and therefore, not acceptable to especially the aggrieved candidate(s), some party elites may have an incentive to contest the election as independent, or advocate for ticket splitting overtly or covertly. This is where intraparty coordination failure is said to have occurred. Thus, where a party fails to nominate a single candidate, there is intraparty coordination failure (Benoit 2001; Cox 1999; Golder 2006) and this is likely to increase the likelihood of splitting. Intraparty coordination failures often create opportunity for party elites to engage in ticket splitting. This is because, if the aggrieved nomination seeker and his/her supporters are not happy with say the verdict of the party's parliamentary primaries, in a concurrent election, they will likely vote for the presidential candidate of the party and vote for another candidate or cast a blank ballot. It is worth pointing out however, that a party may have acrimonious primaries where disappointed nomination seekers disagree with the outcome but when party elites succeed in dissuading such nomination seekers from contesting the election as independents, this can be referred to as intraparty coordination success. Table 2.1 below summarizes the observable indicators of intraparty coordination successes and failures and their possible resultant impact on ticket splitting. 
Table 2.1: Observable Indicators of Intraparty Coordination and Possible Impact on Splitting

\begin{tabular}{|l|l|}
\hline Intraparty Coordination Success & Possible impact on ticket splitting/split outcome \\
\hline Limiting nomination & Likely to reduce splitting \\
\hline Running fewer candidates & Likely to reduce splitting \\
\hline Ability to prevent independents & Likely to reduce splitting \\
\hline Creation of a joint platform & Likely to reduce splitting \\
\hline Intraparty Coordination Failure & Possible impact on ticket splitting/split outcome \\
\hline Over nomination & Likely to increase splitting \\
\hline Contentious primaries (independent contestants) & Likely to increase splitting \\
\hline Existence of splinter groups & Likely to increase splitting \\
\hline No policy linkage between candidates & Likely to increase splitting \\
\hline
\end{tabular}

Sources: Authors' own compilation from Benoit (2001), Cox (1999), and Golder (2006)

\subsubsection{Interparty Coordination Successes and Failures}

As indicated above, the first $M+1$ rule, strategic entry decision of party elites, relates to party elites in the same ideological bloc and from different ideological blocs who for strategic reasons would like to contest the election together in a coalition or devise some sort of electoral deal for their mutual benefit (Benoit 2001; Cox 1999; Golder 2006). Often, it is easier for political parties from the same ideological bloc to form a coalition due to policy similarities (Benoit 2001; Cox 1999; Golder 2006). However, at times it becomes necessary for political parties from different ideological bloc to team up to defeat an "undesirable" political party in an election (Cox 1999; Downs 1957; Golder 2006). To succeed in interparty coordination, parties in an alliance are to engage in strategic withdrawal, endorse a common candidate, harmonize their policies, adopt a joint campaign, and secure the backing of party supporters to vote for that candidate. Where this happens, supporters of those parties are likely to vote for all their candidates in concurrent presidential and parliamentary races in a given constituency. In this case, successful interparty coordination will reduce ticket splitting, all things being equal. However, if party elites fail to negotiate strategic withdrawal because some of the parties had already elected their candidates and 
had made substantial investment in their campaigns, engaging in strategic withdrawal will become difficult. In such instances, members of the alliance are likely to campaign against each other (at least one of these legislative candidates will be running under a party label other than the label of the presidential candidate) and will therefore, be advocating for ticket splitting. Instances where coalition parties run legislative candidates under a party label other than the label of the presidential candidate of the coalition, I expect high likelihood of splitting especially from their core supporters. This is because their core supporters will be voting at the presidential and the legislative races for candidates with different party labels. Again, I expect higher likelihood of splitting from short term instrumentally rational voters (that is voters who care only about who wins the present election), in instances where coalition parties run legislative and presidential candidates under single party label but the viable candidates in the different races are from the coalition party in one race and another party in the other race.

Interparty coordination success can lead to ticket splitting if the parties involved in an alliance enter deals. Typically, Ghanaian political elites in alliance prefer deals where instead of conducting the election under a common party brand, one party supports the other in the parliamentary race in return for a similar gesture in the presidential race (Agyeman-Duah 2005; Boafo-Arthur 2006; Darkwa 2019) in a concurrent presidential-legislative race. When such a deal becomes successful, supporters of the parties are likely to vote for one party in say, the presidential race and for another party in the parliamentary race in the same constituency. This increases the chances of ticket splitting leading to a possible split outcome (Agyeman-Duah 2005; Boafo-Arthur 2006; Darkwa 2019; Frempong 2017).

Party elites are often left out when estimating split-ticket voting because the phenomenon is often viewed as the result of voter-level factors. However, as a voter's decision in the voting 
booth is a function beyond the individual (Cox 1997, 1999; Roscoe 2003), elite coordination which affects the available choice set needs to be considered when explaining ticket splitting (Cox 1997, 1999; Roscoe 2003). From the above discussions, it seems that elite interactions (strategic coordination) to greater extent determine the available options for the electorate in an election. In fact, Cox $(1997,1999)$ places elite coordination ahead of voter coordination. Roscoe (2003) argues that voters are like diners in a restaurant who are limited by the available menu. These diners could only make their orders based on the menu. In fact, voter coordination is necessitated by elite coordination and that is why elite coordination is vital in estimating ticket splitting. Table 2.2 below outlines the observable indicators of interparty coordination successes and failures and their possible effects on splitting.

Table 2.2: Observable Indicators of Interparty Coordination and Possible Impact on Splitting

\begin{tabular}{|l|l|}
\hline Interparty Coordination Success & Possible impact on ticket splitting/split outcome \\
\hline Joint nomination/campaigns & Likely to reduce splitting \\
\hline Strategic withdrawal & Likely to reduce splitting \\
\hline Effective negotiations & Likely to reduce splitting \\
\hline Ability to secure members'support & Likely to reduce splitting \\
\hline Interparty Coordination Failure & Possible impact on ticket splitting/split outcome \\
\hline Fight for supremacy & Likely to increase splitting \\
\hline Over nomination & Likely to increase splitting \\
\hline Conflict over policy/ideology & Likely to increase splitting \\
\hline Inability to secure members'support & Likely to increase splitting \\
\hline
\end{tabular}

Sources: Authors' own compilation from Benoit (2001), Cox (1997, 1999), and Golder (2006)

In sum, elite intraparty coordination success is likely to reduce ticket splitting while intraparty coordination failure is likely to increase ticket splitting all things being equal. Similarly, interparty coordination success is likely to reduce ticket splitting while failure is likely to increase splitting. However, that will depend on the kind of alliance formed by coalition parties and how they are able to secure the support of their members and those of the electorates. More importantly, 
it will depend on the viability of the coalition candidates vis-à-vis the candidates of other contesting parties. In some instances, there could be elite coordination failure but if there are no viable alternatives, that will not increase splitting. Ultimately, voter coordination will depend on the viability of candidates of all the contesting political parties in for instance, concurrent presidential-parliamentary contests. However, because in situations where both MPs and presidents are directly elected in general elections the presidential office is more valued (Birch 2003; Kadima 2006; Reif and Schmitt 1980; Tavits 2008), I expect elites to coordinate more on the presidential race. Again, because each party is expected to present only one presidential candidate nationally, parties are able to attract presidential candidates of comparable quality. The parliamentary contest on the other hand, is saddled with enormous coordination challenges ranging from subpar candidates to internal conflict within a constituency, the parliamentary contests are more likely to experience increased voter defection leading to more ticket splitting than the presidential race. Again, because each constituency is unique, the constituency parliamentary coordination problems will differ from constituency to constituency. In this case, some constituencies are expected to experience more ticket splitting than others. Ultimately, the fundamental logic of voter coordination and ticket splitting is that, voters will defect from unviable candidates in the different races. A voter's electoral decision may be described as ticket splitting if candidates the voter selects in the different races belong to different parties.

\subsection{STRENGTHS AND WEAKNESSES OF THE THEORY}

The strategic coordination theory represented by the two $M+1$ rules is capable of explaining elite- and voter-level coordination as discussed in the preceding sections. This explains why competition in SMD-plurality systems tend to exercise a reductive impact on the number of candidates (Cox 1997, 1999; Duverger 1954). The theory also supports elite and voter coordination 
in PR systems. This is because in PR systems the district magnitude is more than one, viable candidates in these systems tend to be greater than two which means that competition in PR systems favor multipartism. Elites in PR systems can coordinate on more than two candidates and still could achieve their objective of investing in candidates. Voters can also vote for their preferred candidates in PR systems and still influence the electoral outcome (Cox 1997, 1999; Bawn 1999; Rich 2014; Shugart and Wattenberg 2001). The theory can explain ticket splitting in pure SMDs because if the two candidates a voter elects in a concurrent election involving two offices are not from the same party, we have ticket splitting. In pure PR systems, because voters can vote for their preferred candidates in concurrent presidential-legislative contest and still influence the outcome, theory breaks down when it is applied to explain ticket splitting in pure PR systems.

Again, the theory breaks down when it is used in a mixed-member electoral system that combines SMD-plurality and PR. In the first place, scholarship suggests that the $M+1$ rules do not apply in the SMD tier of the mixed electoral system as it is the case under a pure SMD-plurality system (Ferrara, Herron, and Nishikawa 2005; Guinjoan 2016; Herron and Nishikawa 2001). The reason is that, the overlap of the electoral systems creates vote bonus in the PR tier for parties that field candidates in the SMD tier. As a result, parties are motivated to contest in the SMD tier regardless of their chances of winning a seat. Thus, party competition at the SMD tier encourages multiparty system due to contamination effects that the overlap of the two systems create (Ferrara, Herron, and Nishikawa 2005; Herron and Nishikawa 2001; Herron, Nemoto, and Nishikawa 2018). Proponents of contamination effects argue that the overlap of the two systems in mixed electoral systems creates symbiotic interactions that boosts a party's votes at the PR tier (vote bonus) when that party contests in SMD tier. 
Samuel K. Darkwa

\subsection{WHY GHANA}

Ghana presents the appropriate kind of environment to explore coordination theory to investigate ticket splitting in new democracies. In the first place, like many Anglophone African countries, Ghana uses a pure SMD-plurality system (Wahman 2014) where the $M+1$ rules are applicable. Therefore, it provides a suitable environment to investigate how elite coordination (intraparty and interparty) interacts with voter coordination to explain the phenomenon of ticket splitting in new democracies. Second, elections in Ghana are competitive between the two major political parties (NDC and NPP) whose vote share is typically more than 90 percent combined, and results have shifted since 1992 (Frempong 2017; Graham et al. 2017 Kumah-Abiwu 2017; Lindberg 2007, 2013; Weghorst \& Lindberg 2013). Between 2000 and 2016, the nation has experienced three alternations in power which occurred in 2000, 2008, and 2016 with the ruling party handing over power to the main opposition party. One thing that has characterized these elections and alternations in power is skirt and blouse voting/skirt and blouse outcomes ostensibly due to elite (mis)coordination (Frempong 2017; Lindberg 2007, 2013; Lindberg and Morrison 2008; Weghorst \& Lindberg 2013). Party elites either due to interparty coordination or intraparty coordination problems have openly and covertly advocated for ticket splitting. In fact, elite (mis)coordination has helped in the smooth transition of political power often in peaceful manner because, elites through their (mis)coordination could predict the outcome of the elections with certain level of certainty (Frempong 2017; Graham et al. 2017; Yobo and Gyampo 2015). These reasons make Ghana an ideal laboratory to investigate how elite and voter coordination interact to produce ticket splitting and facilitates political transitions or alternations of power in new democracies. Although what prevails in Ghana may not be fully generalizable in all emerging democracies, it still presents a suitable place to engage in such an exercise. 
It worth pointing out that this study is applicable to most of the developing democracies in Africa, Eastern Europe, and Latin America whose political trajectory is similar to that of Ghana. Like many other emerging democracies, Ghana has a history of political instability stemming from military interventions especially where political elites are disunited. Thus, the coordination theory adopted by this dissertation to analyze ticket splitting made the selection of Ghana ideal laboratory to test whether it closely fits the theory. In his book, Regarding Politics: Essays on Political Theory, Stability, and Change, Eckstein (1992) made a case for the use of what he referred to as a 'crucial case' to test a theory's validity. He argues that, if one is to have confidence in a theory's validity, then it should be applicable to a crucial case in the sense that, that case must closely fit the theory. In the future, I can look at how elite coordination affects ticket splitting, representation, and democratic stability.

\subsection{REFERENCES}

Abramson, Paul R., et al. 2010. "Comparing strategic voting under FPTP and PR." Comparative Political Studies 43.1: 61-90.

Agyeman-Duah, Baffour. 2005. Elections and Electoral Politics in Ghana's Fourth Republic. Accra: Ghana Center for Democratic Development. No. 18.

Bawn, Kathleen. 1999. "Voter Responses to Electoral Complexity: Ticket Splitting, Rational Voters and Representation in the Federal Republic of Germany." British Journal of Political Science 29.3: 487-505.

Benoit, Kenneth, Daniela Giannetti, and Michael Laver. 2006. "Voter Strategies with Restricted Choice Menus.” British Journal of Political Science 36.3: 459-485.

Benoit, Kenneth. 2001. "Two Step Forward, One Steps Back: Electoral Coordination in the Hungarian Elections of 1998." Typescript. Trinity College, Dublin.

Birch, Sarah. 2003. Electoral systems and political transformation in post-communist Europe. Springer.

Boafo-Arthur, Kwame. 2006. "The 2004 General Elections: An Overview”, In Boafo-Arthur, ed., Voting for Democracy in Ghana: The 2004 Elections in Perspective, Vol. 1. Accra: Freedom Publications, pp. 33-58.

Cox, Gary W. 1997. Making Votes Count: Strategic Coordination in the World's Electoral Systems. Cambridge University Press. 
Cox, Gary W. 1999. "Electoral rules and electoral coordination." Annual Review of Political Science 2.1: 145-161.

Cox, Gary W. 2006. How Electoral Reform Might Affect the Number of Political Parties in the Netherlands. Acta Politica 41: 133-45.

Darkwa, Samuel K. 2019. "(Mis)coordination: Why Would Ghanaian Political Actors and Political Parties Strategically Encourage Split-Ticket Voting?" In Ghanaian Politics and Political Communication. Edited by Obeng-Gyasi, Samuel and Emmanuel Debrah. [forthcoming] London: Rowman and Littlefield.

Downs, Anthony. 1957. An Economic Theory of Democracy. New York: Addison Wesley.

Duverger, Maurice. 1954. Political Parties: Their Organization and Activity in The Modern State. London: Methuen.

Duverger, Maurice. 1959 Political Parties: Their Organization and Activity in the Modern State. Methuen.

Eckstein, Harry. 1992. Regarding politics: Essays on Political Theory, Stability, and Change. Univ of California Press.

Ferrara, Federico, and Erik S. Herron. 2005. "Going it alone? Strategic entry under mixed electoral rules.” American Journal of Political Science 49.1 (2005): 16-31.

Ferrara, Federico, Erik Herron, and Misa Nishikawa. 2005. Mixed Electoral Systems: Contamination and its Consequences. Springer.

Frempong, Alexander Kaakyire Duku. 2017. Elections in Ghana: 1951 - 2016. Digibooks Ghana Ltd.

Golder, Sona Nadenichek. 2006. The logic of pre-electoral coalition formation. Ohio State University Press.

Graham, Emmanuel, et al. 2017. "The Third Peaceful Transfer of Power and Democratic Consolidation in Ghana." Journal of Pan African Studies 10.5.

Gschwend, Thomas. 2007. "Ticket-splitting and strategic voting under mixed electoral rules: Evidence from Germany.” European Journal of Political Research 46.1: 1-23.

Guinjoan, Marc. 2016. Parties, elections and electoral contests: Competition and contamination effects. Routledge.

Herron, Erik S., and Misa Nishikawa. 2001. "Contamination Effects and the Number of Parties in Mixed-Superposition Electoral Systems.” Electoral Studies 20.1: 63-86.

Herron, Erik S., Kuniaki Nemoto, and Misa Nishikawa. 2018. "Reconciling Approaches in the Study of Mixed-Member Electoral Systems." In Erik S. Herron, Robert J. Pekkanen, and Matthew Soberg Shugart (eds.). Oxford Handbook of Electoral Systems. Oxford: Oxford University Press.

Hobolt, Sara B., and Jeffrey A. Karp. 2010. "Voters and coalition governments." Electoral Studies 29.3: 299-307. 
Kadima, Denis, and Cassam Uteem. 2006. The politics of party coalitions in Africa. EISA.

Kollman, Ken. 2018. "Election Data and Levels of Analysis." In Erik S. Herron, Robert J. Pekkanen, and Matthew Soberg Shugart (eds.). Oxford Handbook of Electoral Systems. Oxford: Oxford University Press. 405-423.

Kumah-Abiwu, Felix. 2017. "Issue Framing and Electoral Violence in Ghana: a Conceptual Analysis." Commonwealth \& Comparative Politics 55.2: 165-186.

Lindberg, Staffan I. 2007. "Institutionalization of Party Systems? Stability and Fluidity Among Legislative Parties in Africa's Democracies." Government and Opposition 42.2: 215-241.

Lindberg, Staffan I. 2013. "Have the Cake and Eat It: The Rational Voter in Africa." Party Politics 19.6: $945-961$.

Lindberg, Staffan I., and Minion KC Morrison. 2008 "Are African Voters Really Ethnic or Clientelistic? Survey Evidence from Ghana.” Political Science Quarterly 123.1: 95-122.

Reif, Karlheinz, and Hermann Schmitt. 1980. "Nine Second-Order National Elections-A Conceptual Framework for the Analysis of European Election Results." European Journal of Political Research 8.1: 3-44.

Rich, Timothy S. 2014. "Split-Ticket Voting in South Korea's 2012 National Assembly Election". Asian Politics \& Policy-Volume 6, Number 3-Pages 455-469

Roscoe, Douglas D. 2003. "The Choosers or the Choices? Voter Characteristics and the Structure of Electoral Competition as Explanations for Ticket Splitting." Journal of Politics 65.4: 11471164.

Shugart, Matthew, and Martin P. Wattenberg. 2001. Mixed-Member Electoral Systems: The Best of Both Worlds? Oxford University Press.

Tavits, Margit. 2008. "On the Linkage Between Electoral Volatility and Party System Instability in Central and Eastern Europe.” European Journal of Political Research 47.5: 537-555.

Thrasher, Michael, et al. 2014. "Voting Systems in Parallel and the Benefits for Small Parties: An Examination of Green Party Candidates in London Elections." Party Politics 20.1: 134-142.

Wahman, Michael. 2014. "Electoral Coordination in Anglophone Africa." Commonwealth \& Comparative Politics 52.2: 187-211.

Weghorst, Keith R., and Staffan I. Lindberg. 2013. "What Drives the Swing Voter in Africa?" American Journal of Political Science 57.3: 717-734.

Yobo, Eric, and Ransford Edward Van Gyampo. 2015. "Third Parties and Electoral Politics in Ghana's Fourth Republic.” J. Pol. \& L.8: 7.

\subsection{NOTES:}

1. The dissertation explores ticket splitting using multiple datasets (survey dataset from Afrobarometer Round 6, aggregate electoral dataset from Elections Passport [1996-2016], and fieldwork carried out in 2017). 


\section{CHAPTER 3. INDIVIDUAL LEVEL OF ANALYSIS}

Electoral coordination occurs... where competitors coordinate entry and citizens coordinate votes (Cox 1999, 145).

\subsection{CHAPTER INTRODUCTION}

Ticket splitting or, split-ticket voting is fairly a common phenomenon in Ghanaian electoral politics, to the extent that the concept has been given a local term "skirt and blouse voting." Though the concept is familiar to most Ghanaian voters, the phenomenon has not received much scholarly attention. Consequently, the literature on split-ticket voting has produced two versions of "skirt and blouse voting" with distinct, but related, meanings. In its first usage, skirt and blouse relates to the overall electoral outcome at the constituency level where different political parties or a blend of party candidates and independent candidates are elected at the constituency level for the presidency and the legislature (Daddieh 2011; Frempong 2017). This is equivalent to split district outcome (Cummings 1966; Burnham 1965; Feigert 1979) and therefore different from the traditional split-ticket voting in mainline political science literature. Its second usage refers to situations where voters at the voting booth choose candidates from different political parties or strategically withdraw from a candidate (Burden and Helmke 2009; Campbell and Miller 1957; Chandra 2009). In this way, the Ghanaian phenomenon (skirt and blouse voting) is similar to splitticket voting as used in conventional political science literature. Two reasons have been given as the motivation for the individual act of skirt and blouse voting in Ghana by some scholars and political actors. First, voters are said to be voting based on their evaluative assessment of the contesting candidates. Thus, if candidates that voter evaluative assessment favor are not from the same party, the result is ticket splitting (Asunka 2016; Lindberg 2013; Ichino and Nathan 2013, 2017; Weghorst and Lindberg 2013). The second explanation advanced as the motivation for skirt and blouse voting is where supporters of a political party vote for the party's presidential candidate 
but vote for a parliamentary candidate (PC) from a different political party or an independent candidate (Boafo-Arthur 2006, 2008; Debrah and Gyampo 2013).

Thus, the Ghanaian literature has used the same concept (skirt and blouse voting) to mean a split district outcome and split-ticket voting. Therefore, for clarity and comparability, this dissertation would like to distinguish between skirt and blouse outcome which is in tandem with its first usage and skirt and blouse voting which is in sync with its second usage. This distinction is necessary to harmonize the phenomenon with split-ticket voting and split district outcome (Brunell and Grofman 2009; Burden and Kimball 1998, 2009) to enable us compare and contrast the Ghanaian ticket splitter with similar voters elsewhere. The distinction is also necessary given that the concept has been used interchangeably to signify split district outcome and split-ticket voting. This creates conceptual ambiguity that needs some sort of reclassification to harmonize it with similar concepts used in political science for consistency and comparability.

One may ask, why would the supporters of a political party defect from their PC in favor of a candidate of another party? Why would they not withdraw from both the presidential and the PCs or abstain from the presidential candidate? What is so unique about the presidential candidate and not about the PCs? Again, why will some voters split their tickets and others will not? What distinguishes the ticket splitter from a straight ticket voter? These are some of the questions that this chapter addresses. The basic argument of this chapter is that voters respond to the options available to them in each election by coordinating their votes to achieve expected outcome given the institutional framework that governs how votes are translated into seats. That is, their choices are determined by how party elites have coordinated their entry given the electoral system in operation. This is aptly captured by the quote from Cox (1999) at the beginning of this chapter which asserts that electoral coordination takes place where elites coordinate entry and citizens 
coordinate votes. For instance, in single-member first-past-the-post (FPTP) districts, voters are likely to coordinate (concentrate) their votes around the two viable candidates for their votes to count (Cox 1997; Duverger 1954). This will create ticket splitting if the candidates elected in the two races are not from the same party. Also, in contexts where parties from the same political ideology enter the electoral contest by presenting more than one candidate, voters are likely to coordinate their votes for their votes to count. If candidates voted for in the different races by an electorate are not from the same party, the voter would be described as engaged in ticket splitting.

This chapter uses individual-level survey data to empirically assess the theoretical argument made at the outset of this dissertation which is based on coordination problems faced by parties, candidates and voters (Cox 1997, 1999). In his groundbreaking work, Making Votes Count: Strategic Coordination in the World's Electoral Systems, Cox (1997) argued that voter coordination is due to party elites' failure to strategically coordinate their entry as well as their efforts and resources. In view of this, the chapter seeks to find out how the individual level of analysis elucidates the coordination problems faced by parties, candidates and voters in Ghana and how it accounts for skirt and blouse voting in that country. In other words, the chapter seeks to find out how voters coordinate their votes after parties and candidates have entered the election. The chapter addresses the following questions: why would a voter withdraw support from his or her party's PC in favor of a PC from another party but would vote for his or her party's presidential candidate and vice-versa? Are the Ghanaian skirt and blouse voters (ticket splitters) different from their counterparts in the rest of the world?

The rest of the chapter is made up of four parts. In the next part, I review several existing theories of voter behavior and relate them to the question of split-ticket voting. These theories establish the hypotheses that evaluate my main argument about coordination and several alternate 
explanations. Section 3.3 addresses the data and the various variables used to evaluate the hypotheses and their measurements. Thus, the main dependent variable, split-ticket voting or skirt and blouse voting, as well as the explanatory and control variables are also discussed in this section. Section 3.4 discusses the model of the split-ticket voting which is coordination based. The model is based on how elite coordination problems impact ticket splitting. It then presents the empirical analysis of a fitted binary logistic regression which is followed by the discussions of the results. The chapter ends with section 3.5 . The section makes a case that no single factor can adequately explain ticket splitting and given the Ghanaian experience, coordination problems faced by party elites collectively become a strong candidate for one explanation of the conundrum of ticket splitting, a recurrent trend in electoral studies. It also affirms the primacy of the voter in the determination of the people's representation in the national assembly, addressing who occupies the presidency and that political accountability resides in the electorate.

\subsection{THEORIES ON TICKET SPLITTING AT THE INDIVIDUAL LEVEL}

When skirt and blouse voting is mentioned in Ghana, the meaning it conveys to the audience is that the winners at the legislative and presidential races in a given constituency are not from the same political party. A curious listener's first impulse or instinct will be to ascertain the political identities of the winners of the presidential and parliamentary slots of the constituency who happen to come from different political parties. Thus, a reference to skirt and blouse voting in the first place denotes a split outcome. The second meaning, which is often lost out in the details is the individual voter behavior that produces the split outcome. Consequently, this chapter on the individual level explanation of skirt and blouse voting investigates the micro-foundations of skirt and blouse outcomes which must be established to put us in a better position to understand why skirt and blouse outcomes emerge. 
Establishing the individual level determinants of skirt and blouse voting will also enhance our understanding of the contexts in which split outcomes are most likely to occur. Furthermore, conducting the individual-level analysis of skirt and blouse voting will better position us to find out if Ghanaian voters are distinctively and intrinsically different from ticket splitters in other parts of the world. We will also be better disposed to understand why some voters will split their ballots and others will not and account for why supporters of political parties will like to strategically abstain or withdraw support for their parties. It will also help us understand how variations in coordination problems among parties cause some political parties to attract more ticket splitting than others. To fulfill these tasks, it is important to link this study to the literature on split-ticket voting in light of what occurs in Ghana.

\subsubsection{Strategic/Policy-Balancing}

Critical early work on split-ticket voting outlines a policy balancing theory which is derived from a proximity spatial model in which voters prefer policies nearest to their ideal points (Downs, 1957). Fiorina's policy-balancing model was developed along Downs's idea and operates on the assumption that voters are generally concerned with the overall orientation of the policy implemented by a government that wins an election. It asserts that political parties hold different positions on the ideological continuum; moderate voters who are positioned at the median segment will be more likely to split their votes to achieve non-extreme policies. This model further assumes that voters are rational and are likely to maximize their utilities to obtain optimal policies from casting a split-ticket (Fiorina, 1988, 1996; Kedar, 2005). In short, the theory asserts that most voters are generally assumed to favor nonextreme ideologies and would therefore, split their ballots to achieve that objective. 
Contrary to the Fiorina model, other studies have shown that high party polarization gives voters distinct choices while ideological or perceived party similarity blurs voter choice and contributes to ticket splitting (Beck et al. 1992; Key 1966; Petrocik 1991; Petrocik and Doherty 1996; Roscoe 2003). This theory indicates that we should expect the likelihood of splitting where voters do not see much difference between the parties. That is, where the extreme right and extreme left parties move close to the center, there is high likelihood of splitting all things being equal. Thus, to Fiorina, voters split to achieve policy moderation or split to make the parties look alike. Other scholars like Key (1966), Petrocik (1991), Beck et al. (1992), and Petrocik and Doherty (1996) argue that voters split because parties are similar. This dissertation leans more towards the position of the other scholars than that of Fiorina because voters are likely to split when they see no difference between the parties. Thus, the first hypothesis of this chapter is:

H1: the more similar the parties become in voter perception, the greater the likelihood of ticket splitting and hence split district outcome.

This means that where party positions become less differentiated either because parties and candidates strategically deviate from their ideological and or issue positions, they are more likely to influence voters to split their votes (Burden and Kimball 2009; Key 1966; Page 1978). Research has shown that where there are clear differences between the political parties, voters are more likely to rely on ideological and party positions when casting their votes and therefore, more likely to cast straight-ticket ballots. On the contrary, when parties blur policy and ideological differences, voters are more likely to rely on other considerations when voting and therefore, more likely to split their tickets (Key, 1966; Roscoe 2003). Key (1966) aptly captures this when he argues that clarity from the political parties produces clarity from the electorates while confusion from political parties causes confusion in voters leading to ticket splitting. 
It has been argued that for voters to be able to split their votes based on their assessment of party differentiation and policy positions, they must be sophisticated (Abramson 1983; Converse 1964; Kinder 1983). Other scholars such as Chandra (2007, 2009) and Mclaughlin (2008) are of the view that voters do not need to be sophisticated in order to be strategic in their choices but rather update their information by observing the preferences of other voters, often through information gleaned in opinion polls. Thus, voters can coordinate their choices to achieve their intended electoral and policy outcomes. What this means is that at the individual level, as candidates and parties converge ideologically, voters who are located at the middle segment of the ideological continuum are likely to split their votes based on their cognitive abilities and signals received from the environment. Parties and candidates who are located at the extreme segments of the ideological scale are likely to induce voters to cast straight ballots. Thus, where elite coordination leads to ideological polarization, voter coordination will result in straight-ticket voting and where elite coordination creates ideological similarity, voter coordination will yield ticket splitting. Where the total number of split-tickets and those who roll off their ballots as well as spoil ballots are more than straight ticket votes, there is likely to be split district outcome.

\subsubsection{Strategic Voting}

Related to strategic/policy balancing discussed above is the concept of strategic voting. The classic literature on strategic voting emerges from the Duvergerian model that asserts that voters will abandon unviable parties and candidates in place of viable ones in FPTP systems (Duverger 1954). Many scholars have built on Duverger's model to mean that in proportional representation (PR) systems where seats are allocated based on the proportion of votes received, voters are likely to vote sincerely while in pure single member districts (SMDs) with plurality rules, supporters of minor parties often face incentives to vote strategically to avoid wasting their 
votes (Cox 1997; Karp 2009). An exception to this rule is that, in an SMD race with a majority runoff rule, voters are not likely to vote strategically, especially in the first round (Cox 1997; Duverger 1954). In mixed-member electoral systems which combine two different electoral rules to allocate seats to the same legislative house, voters are often faced with the conundrum of making the most of their votes. In such cases, it is expected that voters in SMD-plurality tiers would defect from nonviable district competitors toward the ideologically closest viable candidate (Duverger 1954; Rich 2014). On the contrary, voters under the PR tier will vote for their preferred candidates as the electoral outcome is based on the proportion of votes garnered, hence voters under PR have little reason to defect from their first choice (Bawn 1999; Rich 2014; Shugart and Wattenberg 2001).

However, scholars whose research is based on contamination effects argue that contrary to these expectations, the use of different electoral rules in the same voting district creates conditions that may undermine the Duvergerian model. These scholars found that, unlike the pure SMDplurality systems that have reductive effect on the number of parties, parties who contest in the SMD tier of mixed-member systems receive vote bonus at the PR tier (Ferrara, Herron, and Nishikawa 2005; Guinjoan 2016; Herron and Nishikawa 2001). This vote bonus motivates parties to contest in the SMD tier regardless of their chances of winning a seat. Consequently, party competition at the SMD tier produces a multiparty system in the SMD component similar to the PR component (Ferrara, Herron, and Nishikawa 2005; Herron and Nishikawa 2001). Thus, strategic voting in a mixed-member electoral system is complex such that a voter who votes sincerely in the PR tier may still vote sincerely for a third-ranked candidate in the SMD component and this could amount to straight ticket voting. Another voter who votes sincerely at the PR tier may vote strategically in the SMD tier if the preferred candidate is the third-ranked contender 
(Ferrara, Herron, and Nishikawa 2005; Herron and Nishikawa 2001; Herron, Nemoto, and Nishikawa 2018). Ultimately, strategic voting and therefore, party competition in mixed electoral system is a complex one and defies the Duvergerian model (Ferrara, Herron, and Nishikawa 2005; Guinjoan 2016; Herron, Nemoto, and Nishikawa 2018).

It has also been found that in contexts where parties must cross a certain threshold (for instance, as it is the case in Germany and New Zealand where parties are required to poll five percent to qualify for seat share), voters are likely to vote for their next alternative if their first preference is not likely to meet the five percent threshold (Blais et al., 2004; Cox, 1997; Karp 2009). Thus, voters are more likely to split their tickets to either support their second preferred candidate or defeat their least preferred alternative. This means that voters cast strategic votes to achieve a desired outcome. This is what Cox (1999) meant when he stated:

"strategic" refers to actions that are primarily instrumental as opposed to consummatory that is, actions taken because of their perceived impact on the final outcome of the election, rather than because of any intrinsic value they may have (Cox 1999, 149).

It has also been argued that often, supporters of smaller parties may withdraw support from their preferred parties and or candidates if such choices would result in wasting of their votes (Bawn 1999; Benoit et al. 2006; Burden and Kimball 2009; Gschwend et al. 2003). Thus, assessing the options available to them, voters of smaller parties are more likely to split their tickets if their parties do not stand the chance of making any meaningful electoral impact. Similarly, instances where smaller parties are not able to run candidates in both legislative and presidential races, their core supporters are likely to split their votes by voting for their parties in races they run and other parties in races their parties do not run. Therefore, I expect supporters of a smaller party to split their votes if the party runs a legislative candidate but not a presidential candidate, sincere supporters of that party are likely to split their tickets. The reason is that they will vote for their 
Samuel K. Darkwa

party's candidate in the legislative race and for a different party's candidate in the presidential race."

All things being equal, the strategic voting of the supporters of smaller parties are likely to go this way: First, they are likely to vote sincerely for their parties in areas and in races that these parties are likely to make electoral impact. For instance, generally, in PR systems smaller party supporters are likely to vote sincerely for their parties. While in SMD systems, in areas and in races that the smaller parties are not likely to make electoral impact, their supporters are more likely to withdraw their support to vote for parties whose policies and ideologies are similar to theirs and for the most viable candidates. Furthermore, in areas that the smaller parties do not contest both races, we expect their supporters to vote strategically because where they elect their parties in one race, they will need to vote to prevent the victory of their least preferred alternative in the other race. In this way, they will vote for their next alternative or vote to defeat the least preferred of the major contenders in that area or race.

As stated above, strategic voting will translate into ticket splitting where the parties that an electorate votes for in the different races are not from the same party. Similarly, if the parties that supporters of smaller parties vote for in the different races are not from the same party, we have ticket splitting. Benoit et al. (2006) refers to the kind of ticket splitting from supporters of smaller parties as restricted choice menu, largely because often they are compelled to split because their parties are unable to contest in all races in all constituencies. It has often been argued that the challenges faced by smaller parties are largely due to their inability to offer enough choices to their supporters (Benoit et al. 2006). Thrasher et al. (2014) think that smaller parties often create ticket splitting due to misallocation of scarce resources and that if they master the allocation of their resources, they can overcome this kind of splitting. 


\subsection{3 (Mis)coordination Ticket-Splitting (MCTS)}

Connected to strategic voting is the concept of "(mis)coordinated ticket-splitting" (MCTS). There are two strands of MCTS: where there is over nomination from ideologically similar parties and where there are intraparty conflicts (within the same party) either due to personality differences or nomination problems (Benoit 2001; Cox 1999; Golder 2006; Navia and Saldaña 2015). The first strand of MCTS is said to occur where ideologically similar parties do not harmonize their entry to produce a joint list or single candidate but they all contest in the same constituency seeking the votes of the same voters (Cox 1999; Navia and Saldaña 2015). MCTS is likely to produce ticket splitting especially if the supporters of such parties do not want to waste their votes. Both Cox (1999) and Navia and Saldaña (2015) found that the Concertación Alliance (Concertación Party) of Chile fell victim to MCTS because they did not coordinate their entry. In this way, they all "fall together" (lose the election) because of their failure to coordinate their efforts. MCTS is not unique to Chilean politicians ${ }^{1}$; it has also been applied to Japanese parties who often over-nominate candidates leading to voters withdrawing from such parties in order not to waste their votes (Cox 1999). Cox (1999) observed that Japanese parties' elites who failed to coordinate their entry often jointly lost the elections and therefore, came to be associated with a preexisting nonpolitical word, tomodaore "falling down together" (Cox 1999, 152). Thus, the term tomodaore is used to describe the defeat associated with elite miscoordination.

The second category of MCTS occurs where within the same political party, nomination problems cause some members to defect and contest the election as independent candidates or where there is no proper cohesion between the presidential and PC's campaign (Birch 2003; Cox 1997, 1999; Debrah 2004; Tavits 2008). In this way, there is high likelihood of ticket splitting because, the probability of the same electorates voting for the presidential and PCs from the same 
party is very slim. When party elites from the same party are divided, it encourages ticket splitting (Cox 1999; Benoit 2001). Thus, I expect MCTS in instances where party elites from the same ideological bloc fail to coordinate on a single candidate by dissuading nonviable candidates from contesting the election. Similarly, I expect MCTS where within the same party, party elites fail to dissuade unsuccessful primary seekers from contesting the election as independent candidates and, or instances where there is no proper interaction between the presidential candidate and the PCs.

Instances where the second category of MCTS occurs, all things being equal, I expect voters to withdraw from the trailing candidate who could either be the presidential candidate or the PC (Cox 1997, 1999; Benoit 2001). In the case of Ghana, because it practices concurrent Presidential-Legislative elections, if there is no proper coordination between the presidential and parliamentary candidate of a party in a given constituency, party supporters are more likely to split their tickets. However, where the presidential office is treasured more than the parliamentary office, I expect party supporters to defect from the PC and vote for the presidential candidate of their party (Birch 2003; Kadima 2006; Reif and Schmitt 1980; Tavits 2008). Again, where the PCs are subpar in certain constituencies or where there are intraparty conflicts concentrated at local level which basically affects the parliamentary nomination/candidate, I expect supporters to defect from the PC (Benoit 2001; Birch 2003; Cox 1997, 1999; Burden and Kimball 2009; Kadima 2006). So, I expect coordination problems at local level to cause party supporters and floating voters to split away from the PC in favor of the presidential candidate leading to ticket splitting and consequently, split outcome. Thus:

$\mathrm{H} 2$ : the greater the miscoordination at the constituency level, the higher the likelihood of splitting from the parliamentary candidate. 
This means that, elite coordination success is likely to induce party supporters and other electorates to vote for all the party's candidates. In this case, elite coordination success and ticket splitting are inversely related, meaning as elites succeed in coordination there will be less ticket splitting and as elites fail in coordination there will be more ticket splitting. However, in cases where ideologically similar parties present more than one candidate, voters who support that ideological tradition may be indifferent towards the candidates and that is likely to cause ticket splitting. Again, where nomination problems and factions divide a political party or there is no policy linkage between the presidential and the PC, there will be MCTS until such a time that the coordination problems are resolved. As in all other cases, MCTS will produce skirt and blouse outcome only if the net skirt and blouse voting and roll offs or abstentions are able to tilt the total number of straight ticket votes in a concurrent election.

\subsubsection{Economic Voting}

The fundamental argument of the economic voting hypothesis could be traced to Downs' (1957) expected utility theory of voting which claims that a voter would favor a candidate who renders the highest expected utility. Fiorina (1981) further developed the Downs's utility argument based on voter rationality by stating that voters will vote for an incumbent president who presided over a prosperous economy and punish incumbent presidents who presided over a deteriorating economy. Furthermore, where an incumbent's competitor promises or shows prospects of better performance or the track record of a challenger trumps that of the incumbent president, voters are more likely to vote for the challenger.

This distinction introduces retrospective and prospective voting into the decision calculus of voters. Helmke (2009) observed that Mexican voters consider the incumbent's economic 
performance in making their decision, but also, they would have to weigh that decision based on the available alternatives. That is, voters may want to vote based on performance, yet if challengers are not viable, they will need to balance inexperienced hands with underperforming incumbents. Similarly, Benton (2005) also argued that Latin American voters would like to punish not only the incumbent but also non-incumbent political actors who have contributed adversely to their present economic circumstance. However, a country's electoral system and available alternatives may inhibit voters' ability to employ economic voting. Thus, economic and electoral concerns interact to affect voting behavior, political accountability, and public opinion in a nation. Finally, Powell and Whitten (1993) argued that a key determinant of economic voting is contingent on clarity of responsibility. In this vein, voter assessment of political actors' performance is limited by the extent to which voters can assign responsibility to political actors.

I expect economic voting variable, sociotropic evaluation, to be positively related to ticket splitting. Since voters who rate the incumbent's performance as poor are more likely to split their votes from the president or the president's party, worse economic performance is likely to be associated with ticket splitting, all things being equal. To make it more precise, if voters who give poor ratings to the president also rate the legislative candidate from the president's party higher, there will be ticket splitting. Thus, the third hypothesis:

$\mathrm{H} 3$ : voters who rate the president low on past economic performance and rate the legislators from the president's party high on approval ratings are more likely to split their tickets.

This will only translate into skirt and blouse outcome if the total number of those who split their tickets and those who roll off their ballots exceed those who vote straight ticket. Thus, the fact that 
Samuel K. Darkwa

we do not observe a skirt and blouse outcome does not mean there was no skirt and blouse voting (Burden and Kimball 1998, 2009).

\subsubsection{Ethnicity}

The scholarship on ticket splitting has also identified ethnicity as variable responsible for the phenomenon in divided societies. The conventional account on ethnicity and voter choice is that voting in ethnic societies is a mere headcount of membership (Horowitz 1985). That is, voters in ethnic communities vote sincerely for their ethnic parties irrespective of the effect of such votes on the final electoral outcome. Thus, there is no strategic voting among ethnic voters (Horowitz 1985). It has also been argued that clientelism (voting for private benefits) is the sole driving force that incentivizes voting in ethnic societies (Lemarchand and Legg 1972; Hyden and Leys 1972; Lemarchand 1972). In contrast to the classic view on ethnic voting, Chandra (2009) posits that voters among Scheduled Caste communities in the northern India do not vote sincerely for their ethnic parties but rather vote strategically to ensure that their decisions make impact on the electoral outcome. This position is in consonance with McLaughlin (2008) who observed that in South Africa, ethnicity is not the motivation when electorates are voting at the national and provincial levels. Voters often select their "true" preferences at the national level but vote for a different party at the provincial level based on their anticipation of what other voters are doing.

In Ghana, scholars are of the view that how ethnicity is viewed needs to be reconsidered in the sense that the electorates vote for their ethnic contestants only where they believe in their ability to perform (Debrah 2016; Frempong 2012, 2017; Osei 2012). The assertion that Ghanaian voters will vote for their coethnic contestants only where they believe in their ability to perform is similar to those of Banducci, Donovan, and Karp (2004) who found the Maori electorate of New 
Zealand to be more critical of their Maori MPs. In Ghana, it is also argued that ethnically-based skirt and blouse voting is a tool used by voters to navigate otherwise difficult voting decision that they must make at the voting booth. After making such a decision, even if it amounts to voting against coethnics, the individuals are able to satisfy party and candidate choice without compromising their conscience (Interview with Mr. Kwesi Jonah in March 2017). The voter settles with the party and candidate that is viable in either race. The solution tool that ethnicity provides the voter is aptly captured by Campbell and Miller (1957) in relation to the conundrum that faces an ambivalent voter in making decision:

This voter is also politically involved but his political motives are in conflict. He may prefer the candidate or policies of one party but feels a personal allegiance to the other, with the result that he cannot fully satisfy his political motives by voting a straight ticket. His splitticket is a compromise solution to his conflict (Campbell and Miller 1957, 312)

Thus, we expect ethnicity to be employed as a tool used by voters to resolve difficult voting decisions especially when it is not obvious to vote straight ticket given the parties and candidates involved in the contest. Therefore, the fourth hypothesis:

H4: voters who share ethnicity with the presidential candidate of one party and parliamentary candidate of another party are more likely to split their tickets if their coethnics are the viable alternatives and they are concerned about most viable options.

Thus, ethnicity is expected to be significant and positive if coethnics are expected to perform better. The cumulative effect of ethnic skirt and blouse voting on skirt and blouse outcomes will depend on the overall impact of the voting choices made by all the voters in a given constituency (Brunell and Grofman 2009). 
Samuel K. Darkwa

\subsubsection{Demographic and Socioeconomic Characteristics of Voters}

Often scholars view ticket splitting from the angle of demographic and socioeconomic features of voters to find out how ticket-splitters differ from other voters (Bybee et al. 1981; Campbell and Miller 1975; DeVries and Tarrance 1972). They have also addressed the topic from the attitudinal point of ticket splitters (Beck et al. 1992; Bybee et al. 1981; DeVries and Tarrance 1972; Gomes and Wilson 2006), while others have touched on political information inventory of these voters (Downs 1957, Gomes and Wilson 2006, Zaller 1992).

Demographically, ticket-splitters are said to be younger (Campbell and Miller 1957; De Vries and Tarrance 1972). Thus, younger voters are more likely to split their tickets than their older counterparts in simultaneous elections. Recent works on age and ticket splitting however, have found contradictory evidence and concluded that the relationship between age and ticket splitting is spurious (Burden and Kimball 1998, 2009; Roscoe 2003).

It has also been argued that ticket splitters are more educated and more likely to have whitecollar jobs (Beck et al., 1992; Dalton, 2013; DeVries and Tarrance 1972). Though there is convergence on education and ticket splitting, some scholars think that education level rather than education in general is significant. For instance, whereas Campbell and Miller (1957) think that lower level of education is associated with ticket splitting, others are of the view that higher level of education has higher probability of ticket splitting (Dalton, 2013; De Vries \& Tarrance, 1972).

The role of income in ticket splitting is found to be mixed. Whereas DeVries and Tarrance (1972) found an association between income and ticket splitting, Roscoe (2003) found income to be related to ticket splitting only in scattered instances and that its impact is insignificant and inconsistent. Men are found by Campbell and Miller (1957) to be more disposed to split their ticket 
than women. However, others found no significant relationship between gender and ticket splitting (Beck et al., 1992; Rallings and Thrasher, 2003).

In addition to demographic and socioeconomic features of ticket-splitters, electoral scholars have also considered attitudinal factors of ticket-splitters such as voter perception and political attitudes toward the political parties. However, the findings are often contradictory. Some scholars have found that the intensity of partisanship and higher interest in politics are inversely related to ticket splitting (Beck et al. 1992; Campbell et al. 1960; Campbell and Miller 1957). In contrast, Maddox and Nimmo (1981) found that largely, all partisans split their ballots but that is context determinant. It is argued that partisans who work for their parties or candidates have strong partisanship and therefore less likely to split their tickets (Burden and Kimball 2009). An individual's interest in the campaign is found to be positively related with ticket splitting (Maddox and Nimmo 1981). In contrast, Beck et al. (1992) found no association between interest in campaign and ticket splitting. Other scholars have found that interest in campaign alone is not likely to affect ticket splitting but those interested in the result of the election are more likely to split their tickets (Mclaughlin 2008; Roscoe 2003). Therefore, I expect to see interest in the campaign to be significant when those interested in it expect a certain electoral outcome. This means that depending on voters' expectations, interest in the campaign may produce ticket splitting or straight ticket voting, and the direction can either be positive or negative. Consequently, I expect the following hypotheses as political attitude hypotheses:

H5A: Voters who attend meetings with candidate(s) or campaign staff are less likely to split. H5B: Voters who work for candidates or political parties are less likely to split their votes. I expect negative association between the variables: "working for a candidate" and "campaign meeting" and ticket splitting. 
Samuel K. Darkwa

\subsubsection{Political Information}

It has been argued that voters who are politically informed are more likely to engage in rational decisions and often rely on information shortcuts referred to as heuristics when deciding on which candidate or party to vote for (Downs 1957; Popkin 1991). Also, a voter's ability to correctly locate issues and candidates on a 7-point ideological scale as well as gather information from the media has been associated with voter sophistication (Neuman 1986; Zaller 1992). Thus, the politically informed are sophisticated voters who make rational decisions on political issues including voting in general and ticket splitting in particular. This is not to make a sweeping generalization that the politically informed and sophisticated persons split their votes because there is conflicting view on political sophistication and ticket splitting. For instance, while Converse (1964) found a negative relationship between political sophistication (political information) and ticket splitting, other scholars found counter evidence (Dalton, 2013; Lachat, 2007). This may mean that politically sophisticated persons are more likely to be strong partisans who are less likely to engage in splitting or they may rely on one-sided information that suit their political inclination. This caveat notwithstanding, the scholarship on ticket splitting has considered political information as one of the variables that induce splitting (Atwood and Sanders 1975; Maddox and Nimmo 1981). However, there is conflicting evidence on reliance on the media for political information and ticket splitting. For instance, while reliance on the print media is found to be associated with splitting (Atwood and Sanders 1975; Bybee et al. 1981), there is no positive relationship between television and ticket splitting (Beck et al. 1992; Bybee et al. 1981; DeVries and Tarrance 1972). With these in mind, the dissertation will control for media (radio, television, and newspaper). It will be interesting to find the relationship and the direction that each media type has on ticket splitting in Ghana as compared with those indicated above. 
In sum, based on the literature related to split-ticket voting, I expect perceived party similarity to increase ticket splitting all things being equal. Thus, to confirm H1, I expect voter perception of party similarity to be positively related to splitting. Next, I expect elite miscoordination to positively relate to splitting to confirm H2. I also expect voters who rate an incumbent president bad on the economy to defect from the president or the president's party to confirm H3. Again, I expect voters who share ethnicity with a presidential candidate of one party and a parliamentary candidate of another party to split their tickets if their coethnics are the viable alternatives to confirm H4. Furthermore, I expect persons who attend political campaigns with candidates and those who work for political parties/candidates to be negatively related to splitting to confirm H5A and H5B. In addition, I expect political information variables such as newspaper, television and radio exposure to be positively related to splitting. Finally, income and education are expected to be positively related to splitting meaning the higher the level of education and the wealthier one becomes, the higher the likelihood of making informed and independent choices including voting.

\subsection{DATA AND MEASUREMENT}

This chapter uses data from the Afrobarometer dataset to assess individual-level attitudes about parties and candidates in Ghana to evaluate the hypotheses listed above. The Afrobarometer is a Pan-African research organization that carries out public attitude surveys on series of topics including democracy, governance, and economic conditions in over 35 countries in Africa ${ }^{2}$ (Network Afrobarometer 2014; Bratton 2004; Fry, 2013). The first round of surveys took place in July 1999 and by March 2018, the research network had published seven rounds of its surveys which have been used extensively by scholars across the globe. This chapter focuses on round six of the survey published in June 2015, because it is the closest to the 2016 Ghanaian election. The 


\section{Samuel K. Darkwa}

surveys are based on personal interviews of persons within the voting age while the sample drawn from 2,400 respondents is nationally representative of the population with regard to demographic, partisanship, occupation and socioeconomic circumstances of the larger Ghanaian society. Also, the surveys were carried out by experts who asked respondents questions in their local languages and this makes responses more likely to be reflective of the true intentions of respondents.

Although the dataset is appropriate and reliable, a substantial number of respondents did not identify with a party when asked in the interview. Although this set of persons could represent the pool of floating voters who often swing the elections (Asunka 2016; Debrah and Gyampo 2013; Weghorst and Lindberg 2013), their failure to properly identify their partisanship poses some challenge to the use of the dataset since one is not sure whether their responses amount to misreporting or not. This aside, the Afrobarometer data poses other problems. First, the survey did not directly ask questions about skirt and blouse voting. Consequently, I resort to proxies to derive possible skirt and blouse voters (that is respondents who do not feel the same level of closeness to the parliamentary and presidential candidates of the same party). Second, the Afrobarometer survey was not carried out right before or after elections therefore, my assessments of likely behavior may understate or overstate skirt and blouse likelihood. Despite these shortcomings, the dataset is capable of testing my research hypotheses in a systematic way.

\subsubsection{Dependent variable}

The main dependent variable of this dissertation is skirt and blouse voting. It is a dichotomous variable - a respondent splits or does not split the ballot. Ideally, I would like to work with a survey that asks respondents the political affiliation of candidates they will vote for in the legislative and presidential elections in order to identify likely ticket splitters. Unfortunately, that is not possible 
because the Afrobarometer questions do not directly assess behavior, therefore, I have to use as close of a proxy as I can get.

For instance, respondents were asked to indicate their closeness to political parties. They were also asked to identify which presidential candidate they will vote for if elections were held tomorrow. However, there was no corresponding question asking which legislative candidate they will vote for in the same election. Therefore, responses for these two questions were used to deduce likely skirt and blouse voters. Those who are likely to split their ballots (respondents who do not feel the same level of closeness to the parliamentary and presidential candidates of the same party) were coded as " 1 ", otherwise coded as " 0 ". Thus, respondents who, for instance, indicated they would vote for NDC presidential candidate but stated that they were closest to the PNC were coded as " 1 ", otherwise coded as " 0 ".

It is important to state that the proxies I used are likely to understate possible ticket splitters given that about 46 percent $(45.58 \%)$ respondents as per Table 3.1 did not indicate their closeness to legislative candidates and as such treated as missing. It could be possible that non-partisan identifiers are more likely to split and since I do not know their candidate preference, I dropped them because it is better to understate likely splitters than to overstate them. Thus, the choice of less likely splitters as my dependent variable is to adopt a relatively conservative approach in order not to overstate my dependent variable. It is also significant to note that more respondents feel closely attracted to the NPP (opposition) presidential candidate (858 respondents, i.e. 35.75\%) than the NDC (incumbent) presidential candidate (557 respondents, i.e. 23.21\%) as per Table 3.2. This is fair because normally, voters are more likely to identify with an incumbent's challenger when the economy is not doing well. This is confirmed by the actual electoral results in Table 3.3 where the NPP presidential candidate won 31 more constituencies (153-122) than the NDC 
presidential candidate. A closer look at Tables 3.1 and 3.2 shows that relatively stable respondents, 23.75 percent and 23.21 percent respectively said they feel closely attracted to the NDC presidential and legislative candidates. Compared to Table 3.3 where the NDC presidential candidate won 16 more constituencies (122-106) than the party's legislative candidates and the NPP legislative candidates won 16 more constituencies (169-153) than the party's presidential candidate shows that largely, splitters withdrew from the NDC legislative candidates in the 2016 general election.

Table 3.1: Respondents' Closeness to the Legislative Candidates

\begin{tabular}{lrc}
\hline \multicolumn{1}{c}{ Name of Political Party } & Number & Percentage \\
\hline National Democratic Congress (NDC) & 570 & 23.75 \\
New Patriotic Party (NPP) & 658 & 27.42 \\
Others & 78 & 3.25 \\
Missing & 1094 & 45.58 \\
Total & $\mathbf{2 4 0 0}$ & $\mathbf{1 0 0 . 0 0}$ \\
\hline
\end{tabular}

Source: Author's Compilation from Afrobarometer Round 6 Dataset

Table 3.2: Respondents' Closeness to the Presidential Candidates

\begin{tabular}{lrc}
\hline \multicolumn{1}{c}{ Name of Political Party } & Number & Percentage \\
\hline National Democratic Congress (NDC) & 557 & 23.21 \\
New Patriotic Party (NPP) & 858 & 35.75 \\
Others & 130 & 5.42 \\
Missing & 855 & 35.63 \\
Total & $\mathbf{2 4 0 0}$ & $\mathbf{1 0 0 . 0 0}$ \\
\hline
\end{tabular}

Source: Author's Compilation from Afrobarometer Round 6 Dataset

Table 3.3: Actual Performance of Presidential \& Legislative Candidates in 2016 Elections

\begin{tabular}{|c|c|c|c|c|}
\hline Name of Political Party & $\begin{array}{l}\text { Constituencies } \\
\text { Won (Pres.) }\end{array}$ & Percentage & $\begin{array}{l}\text { Seats Won } \\
\text { (Legislative) }\end{array}$ & Percentage \\
\hline National Democratic Congress & 122 & 44.36 & 106 & 38.55 \\
\hline New Patriotic Party & 153 & 55.64 & 169 & 61.45 \\
\hline Total & 275 & 100 & 275 & 100.00 \\
\hline
\end{tabular}

Source: Author's compilation from 2016 Electoral Results from Ghana's Electoral Commission 


\subsubsection{Independent Variables}

The main empirical interest in this paper is to test which voter level variables are responsible for skirt and blouse voting in Ghana and to determine whether Ghanaian voters behave in a manner consistent with ticket splitters in other parts of the globe or they do not. The following paragraphs outline how the independent variables are coded. The coding details for all the variables and the questions used are provided at Appendix 3.1.

Perceived party similarities: I have made the claim that perceived party distinctiveness gives voters distinct choice while perceived party similarity blurs voter choice. This means that voters who see significant difference between the parties are likely to vote straight ticket while voters who do not see significant difference between the parties are likely to engage in ticket splitting. To measure perceived party similarities, I use question 62 of the Afrobarometer Round 6 which asked respondents: "Which of the following do you see as the most important difference between the ruling party and opposition parties in Ghana?" The variable perceived party similarities is measured as binary with respondents who see no significant difference between the parties coded as " 1 " otherwise coded as " 0 ". The variable, perceived party similarities, is expected to be positively related to splitting, thus as perceived party similarities increases, splitting increases and as perceived party similarities decreases splitting decreases.

Parliamentary Split: I measure parliamentary split using questions 52A \& 52F that asked respondents their trust in the ruling party and the president. Given that the president is from the ruling party, respondents who do not feel the same level of trust in the ruling party and president are likely to defect from (withdraw from) the PC of the ruling party and vice-versa. The two questions are: Q52A. How much do you trust each of the following, or haven't you heard enough 
about them to say: The President? Q52F. How much do you trust each of the following, or haven't you heard enough about them to say: The Ruling Party? From these questions, I deduced likely parliamentary split (proxy): those who do not feel the same level of trust in the ruling party and president were coded as " 1 ", otherwise coded as " 0 ".

Economic Voting: The analysis incorporates a key variable to assess sociotropic evaluation ${ }^{3}$. Question 4A of the survey asked, "In general, how would you describe the present condition of this country?" sociotropic voting is measured using a five-point scale from 1-5 for "very bad" to "very good". It is expected that those who are not satisfied with the incumbent's economic performance are likely to split their ticket by voting for alternatives and maintain some of the incumbent party's legislators as a hedge/insurance against voting for challengers and incumbents.

Ethnic minority: In Ghana, the two dominant political parties, NDC and NPP have their core support from the Ewe and Akan ethnic groups. These two ethnic groups often vote straight tickets and therefore coded as "0" while the remaining ethnic group members coded as " 1 " because they are more likely to split their tickets ${ }^{4}$. This variable was computed using responses to the question, "What is your ethnic community, cultural group or tribe?" Ethnic minority is expected to be positively related to ticket splitting especially in situations where electorates from minority ethnic groups coordinate their votes to impact the electoral results.

Campaign Meetings: I generate the variable campaign meeting using question 23B, "Thinking about the last national election in 2012, did you: Attend a meeting with a candidate or campaign staff?" Campaign meeting is a dichotomous variable with "Yes" and "No". All things being equal, respondents who do attend political party's campaign with candidates are said to have strong partisanship and therefore less likely to split their tickets while those who do not attend are 
weak partisans. Thus, respondents who answered "Yes" are coded as "1", otherwise coded as "0". I expect voters who attend campaign meetings with candidates to be negatively related to splitting.

Work for Party/Candidate: Just like those who attend political parties' campaign, those who work for political parties are expected to have strong partisanship and therefore less likely to split their ballots while those who do not are weak and therefore more likely to split. The variable, Work for a candidate, was generated using question 23D, "Thinking about the last national election in 2012, did you: Work for a candidate or party?" Respondents who answered "Yes" are coded as " 1 ", otherwise coded as " 0 ". This variable is expected to be negatively related to splitting meaning persons who work for a candidate are less likely to engage in ticket splitting.

\subsubsection{Control Variables}

Education: The variable education was generated using the education level of respondents. This variable is coded on a ten-point scale (0-9) representing respondents who do not have "formal schooling" to those with "post-graduate education". Seven of the respondents did not select their education level while three selected the "I do not know" option. These two categories of respondents were considered as missing. Education is expected to be positively related to splitting.

Male: The variable male was generated using respondents' sexes. Female respondents were coded as " 0 " and male coded as " 1 ".

Residence: Under residency, the survey sampled respondents from the urban and rural areas of the country. About 46 percent of the respondents were sampled from the rural areas and the remaining 54 percent from urban areas. I coded residents from urban areas as " 1 " because they are expected to be more sophisticated and therefore more likely to split their votes. Rural residents were coded as " 0 " because they are expected to vote straight ticket, all things being equal. 
Samuel K. Darkwa

Age: The variable age was generated using respondents age which range between 18 and 105 and was coded as continuous. I expect age to be negatively related to splitting.

Income: Income is on a five-point scale ranging from those who "never go without cash income" to those who "always go without cash income" coded " 0 " - " 4 " respectively for the Model 1. Generally, respondents who have regular source of income are considered to be independent and therefore likely to split their tickets. This variable was generated using responses to question 8E, "Over the past year, how often, if ever, have you or anyone in your family: Gone without cash income?"

Political Information/Sophistication: Political information/sophistication variables; television radio, and newspaper exposure were generated using question 12A-C, "How often do you get news from the following sources: Radio, TV, and Newspaper? Respondents who listen to radio daily are thought to be politically informed and therefore sophisticated in their decisions. These voters are more likely to split their tickets and are therefore coded as "1" otherwise coded as " 0 ". The expected direction of radio exposure is positive meaning as radio exposure increases, ticket splitting is expected to increase, all things being equal. Respondents with television and/or newspaper exposure are expected to be well informed like their radio exposure counterparts. Therefore, respondents who watch television and/or those who read newspaper(s) on daily basis are coded as " 1 " otherwise, coded as " 0 ".

\subsection{Estimation Strategy for Voter Choice under Coordination Theory}

The intuition behind voter choice under the coordination theory operates on the assumption that voters will like their votes to count in the sense that they will like their votes to impact the electoral outcome by voting for their most preferred candidates or parties (Cox 1997, 1999; Karp 
2009; Karp et al 2002). Voters are also constrained by the choices available to them and by the laws governing how votes are translated into seats (Cox 1997, 1999; Duverger 1954; Roscoe 2003). Consequently, they will end up either voting for their preferred candidates/parties or vote in such a way as to help defeat their least preferred choice. In this way, rational voters will coordinate their votes on the most competitive candidates. If the candidates selected in the different races are not from the same political party, we are likely to have split-ticket voting. This dissertation is interested in ticket splitting, that is the core interest of the dissertation is to identify instances where a voter votes for different political parties in a concurrent presidential-legislative election. Consequently, my dependent variable is binary (an electorate votes split-ticket or not), hence, I employed logit regression which is suitable for the dependent variable. I estimated a total of six models to analyze ticket splitting using Afrobarometer Round 6 datasets. In the first model, I regressed the dependent variable on only the control variables. Second, I regressed the dependent variable on only the independent variables. In the third, I regressed the dependent variable on all the other variables both independent and control variables. These were done to determine how the different models/variables affect splitting. There was quite significant amount of missing values in the dataset. Therefore, to ensure that the results are not influenced by missing data, multiple imputation technique was employed to deal with missing data ${ }^{5}$ (StataCorp 2017). In terms of labeling the models, where only the control variables were run, it was labeled Model 1A. Model 2A denotes the regression model with only independent variables while Model 3A denotes the regression model that contains all variables (control and independent variables). In each of these cases, missing values were not replaced. Similarly, where only the control variables were run with missing values replaced, it was labeled Model 1B. Model 2B signifies the model with only independent variables run with missing values replaced. Finally, in Model 3B, all the variables 
Samuel K. Darkwa

were used to run logistic regression with missing values replaced. Thus, six models were employed to test the hypotheses put forward in this chapter using binary logit regression.

\subsubsection{Results}

When only the control variables were employed in logistic regression, radio exposure and newspaper exposure were the only significant variables as shown by Model 1A in Table 3.4. When missing values were replaced through multiple imputation techniques, it was only radio exposure which was significant. Interestingly, none of the demographic variables (education, male, urban, age, and income) was significant as demonstrated by Model 1A in Table 3.4 and Model 1B in Table 3.5 below. I then used only the independent variables to ran logistic regression using the same dataset. At this time, most of the independent variables appeared to be significant and in the expected direction as per Model 2A in Table 3.4 below. Again, where missing values were replaced through multiple imputation techniques as per Model 2B in Table 3.5, the variables maintained their direction in Model 2B as they were originally in Model 2A. Interestingly, when missing values were replaced, sociotropic voting variable which was significant in Model 2A, became insignificant in Model 2B. Also, attendance to campaign meeting which was initially not significant in Model 2A became significant in Model 2B.

Finally, I combined all the variables (control variables and independent variables) to run logistic regression using the same dataset. The results are illustrated in Model 3A in Table 3.4 below. At this time, all the independent variables largely behaved the same way they behaved in Model 2A when only the independent variables were used (compare Model 2A and Model 3A). Interestingly, income which was not significant in Model 1A became the only significant demographic variable in Model 3A. Again, television exposure which was not significant in Model 
Samuel K. Darkwa

1A became significant in Model 3A. Also, newspaper exposure which was significant in Model 1A became insignificant in Model 3A.

Table 3.4: Logit Analysis of Skirt \& Blouse Voting with missing data

\begin{tabular}{|c|c|c|c|}
\hline Variables & $\begin{array}{c}{ }^{6} \text { Model 1A } \\
\text { with Missing Values }\end{array}$ & $\begin{array}{c}\text { Model 2A } \\
\text { with Missing Values }\end{array}$ & $\begin{array}{c}\text { Model 3A } \\
\text { with Missing Values }\end{array}$ \\
\hline Perceived Party Similarities (H1) & & $\begin{array}{l}0.2719 * \\
(0.1502)\end{array}$ & $\begin{array}{l}0.2640 * \\
(0.1554)\end{array}$ \\
\hline Parliamentary Split (H2) & & $\begin{array}{l}0.2674 * \\
(0.1379)\end{array}$ & $\begin{array}{c}0.2806^{* *} \\
(0.1424)\end{array}$ \\
\hline Sociotropic Voting (H3) & & $\begin{array}{l}0.1246 * * \\
(0.0527)\end{array}$ & $\begin{array}{l}0.1242 * * \\
(0.0550)\end{array}$ \\
\hline Ethnic Minorities (H4) & & $\begin{array}{c}0.4021 * * * \\
(0.1326)\end{array}$ & $\begin{array}{c}0.3040 * * \\
(0.1416)\end{array}$ \\
\hline Campaign Meeting (H5A) & & $\begin{array}{l}-0.1604 \\
(0.1797)\end{array}$ & $\begin{array}{l}-0.2435 \\
(0.1851)\end{array}$ \\
\hline Working for a Candidate (H5B) & & $\begin{array}{c}-0.9528 * * * \\
(0.2255)\end{array}$ & $\begin{array}{c}-1.0017 * * * \\
(0.2323)\end{array}$ \\
\hline Education & $\begin{array}{l}-0.0101 \\
(0.0314)\end{array}$ & & $\begin{array}{c}0.0247 \\
(0.0347)\end{array}$ \\
\hline Male & $\begin{array}{l}-0.0071 \\
(0.1193)\end{array}$ & & $\begin{array}{c}0.0923 \\
(0.1334)\end{array}$ \\
\hline Urban & $\begin{array}{l}-0.0450 \\
(0.1272)\end{array}$ & & $\begin{array}{l}-0.0203 \\
(0.1395)\end{array}$ \\
\hline Age & $\begin{array}{c}0.0007 \\
(0.0005)\end{array}$ & & $\begin{array}{c}0.0008 \\
(0.0005)\end{array}$ \\
\hline Income & $\begin{array}{c}0.0617 \\
(0.0429)\end{array}$ & & $\begin{array}{c}0.1205^{* *} \\
(0.0477)\end{array}$ \\
\hline Radio Exposure & $\begin{array}{c}-0.5132 * * * \\
(0.1319)\end{array}$ & & $\begin{array}{c}-0.5115 * * * \\
(0.1448)\end{array}$ \\
\hline Television Exposure & $\begin{array}{c}0.1965 \\
(0.1379)\end{array}$ & & $\begin{array}{l}0.2582 * \\
(0.1499)\end{array}$ \\
\hline Newspaper Exposure & $\begin{array}{l}0.4498 * * \\
(0.2266)\end{array}$ & & $\begin{array}{c}0.4050 \\
(0.2475)\end{array}$ \\
\hline Constant & $\begin{array}{c}-0.7228 * * * \\
(0.1608)\end{array}$ & $\begin{array}{c}-1.1482 * * * \\
(0.1229)\end{array}$ & $\begin{array}{c}-1.2533 * * * \\
(0.2202)\end{array}$ \\
\hline Observations & 1,510 & 1,343 & 1,311 \\
\hline Log Likelihood & -903.46 & -786.82 & -751.72 \\
\hline McFadden's $\mathrm{R}^{2}$ & 0.012 & 0.043 & 0.058 \\
\hline
\end{tabular}

Standard errors in parentheses $* * * \mathrm{p}<0.01, * * \mathrm{p}<0.05, * \mathrm{p}<0.1$ 
Samuel K. Darkwa

Table 3.5: Logit Analysis of Skirt \& Blouse Voting with missing data (All Variables)

\begin{tabular}{|c|c|c|c|}
\hline Variables & $\begin{array}{c}\text { Model 1B } \\
\text { with Imputation } \\
\end{array}$ & $\begin{array}{c}\text { Model 2B } \\
\text { with Imputation }\end{array}$ & $\begin{array}{c}\text { Model 3B } \\
\text { with Imputation } \\
\end{array}$ \\
\hline Perceived Party Similarities (H1) & & $\begin{array}{c}0.6408 * * * \\
(0.1085)\end{array}$ & $\begin{array}{c}0.6632 * * * \\
(0.1094)\end{array}$ \\
\hline Parliamentary Split (H2) & & $\begin{array}{c}0.2567 * * * \\
(0.0963)\end{array}$ & $\begin{array}{l}0.2553 * * \\
(0.0971)\end{array}$ \\
\hline Sociotropic Voting (H3) & & $\begin{array}{c}0.0412 \\
(0.0387)\end{array}$ & $\begin{array}{c}0.0420 \\
(0.0393)\end{array}$ \\
\hline Ethnic Minorities (H4) & & $\begin{array}{c}0.2416 * * * \\
(0.0928)\end{array}$ & $\begin{array}{c}0.2822 * * * \\
(0.0969)\end{array}$ \\
\hline Campaign Meeting (H5A) & & $\begin{array}{c}-0.3227 * * \\
(0.1293)\end{array}$ & $\begin{array}{c}-0.3251 * * \\
(0.1312)\end{array}$ \\
\hline Working for a Candidate (H5B) & & $\begin{array}{c}-0.9257 * * * \\
(0.1574)\end{array}$ & $\begin{array}{c}-0.9491 * * * \\
(0.1592)\end{array}$ \\
\hline Education & $\begin{array}{c}0.0030 \\
(0.0226)\end{array}$ & & $\begin{array}{c}0.0318 \\
(0.0241)\end{array}$ \\
\hline Male & $\begin{array}{l}-0.1182 \\
(0.0855)\end{array}$ & & $\begin{array}{c}0.0318 \\
(0.0903)\end{array}$ \\
\hline Urban & $\begin{array}{l}-0.0946 \\
(0.0910)\end{array}$ & & $\begin{array}{l}-0.0583 \\
(0.0947)\end{array}$ \\
\hline Age & $\begin{array}{c}0.0002 \\
(0.0004)\end{array}$ & & $\begin{array}{c}0.0001 \\
(0.0004)\end{array}$ \\
\hline Income & $\begin{array}{l}-0.0054 \\
(0.0315)\end{array}$ & & $\begin{array}{c}0.0247 \\
(0.0333)\end{array}$ \\
\hline Radio Exposure & $\begin{array}{c}-0.3097 * * * \\
(0.0975)\end{array}$ & & $\begin{array}{c}-0.2471 * * \\
(0.1012)\end{array}$ \\
\hline Television Exposure & $\begin{array}{c}0.1506 \\
(0.0984)\end{array}$ & & $\begin{array}{c}0.2173 * * \\
(0.1024)\end{array}$ \\
\hline Newspaper Exposure & $\begin{array}{c}0.2000 \\
(0.1747)\end{array}$ & & $\begin{array}{c}0.1894 \\
(0.1827)\end{array}$ \\
\hline Constant & $\begin{array}{c}0.3109 * * \\
(0.1192) \\
\end{array}$ & $\begin{array}{c}0.0053 \\
(0.1229) \\
\end{array}$ & $\begin{array}{l}-0.1682 \\
(0.1541) \\
\end{array}$ \\
\hline Observations & 2,400 & 2,400 & 2,400 \\
\hline McFadden's $\mathrm{R}^{2}$ & & & Note 7 \\
\hline
\end{tabular}

Standard errors in parentheses $* * * \mathrm{p}<0.01, * * \mathrm{p}<0.05, * \mathrm{p}<0.1$

Additionally, I replaced missing values through multiple imputation techniques and used all the variables to run the final regression. At this point, sociotropic variable which lost its significance when missing data was replaced in Model 2B still lost its significance as shown in 
Model 3B in Table 3.5 above. Also, campaign meeting attendance which gained significance when missing values were replaced in Model 2B maintained its significance when missing values were replaced and all variables were used in the Model 3B. Again, interestingly, income which became significant when all variables were used without replacing missing values lost its significance when missing values were replaced as illustrated by Model 3B in Table 3.5. It must be pointed out however, that the standard measure of fit calculated using McFadden's $\mathrm{R}^{2}$ shows that the model does not do a good job in explaining the relationship between ticket splitting and the variables used. This is because, the values of the McFadden's $\mathrm{R}^{2}$ do not lie within the conservative 0.2 and 0.4 range of McFadden's $\mathrm{R}^{2}$ (McFadden 1974, 1977). However, we can state that Model 3A with McFadden's R2 of 0.058 fits better than Model 2A with McFadden's $\mathrm{R}^{2}$ of 0.043 and still better than Model 1A with McFadden's $\mathrm{R}^{2}$ of 0.012 . Standard measure of fit cannot be calculated for multiple imputation technique model. Per Stata Multiple-Imputation Reference Manual Release 15, standard measure of fit does not work with models estimated using multiple-imputation technique.

To estimate how changes in probabilities are likely to affect changes in the likelihood of ticket splitting for each variable, first, I held all other variables at their medians. Second, I generated the change in probability of a given variable, for instance education, by changing education from its minimum to its maximum values. The results are illustrated in Table 3.6 below. As indicated by the changes in probabilities in Table 3.6 below, the probability of ticket splitting increases by (.045) among electorates who perceive the political parties to be different when the voter perception variable is changed from its minimum to its maximum. Also, when the parliamentary split variable, was changed from its minimum to its maximum, the probability of splitting increased by (.048) among voters who do not feel the same level of trust in the ruling 
party and president. Again, when the variable, working for a candidate is changed from its minimum to its maximum, the probability of split is reduced among voters who work for political parties/candidates by (.114). Similarly, when the variable, attend campaign meeting was changed from its minimum to its maximum, the probability of splitting decreases by (.036) among voters who attend campaign meeting with candidates. Finally, the probability of split-ticket voting increases by (.052) among ethnic minorities when the variable ethnic minorities is changed from its minimum to its maximum value.

Table 3.6: Effect of Changing Variables from Their Minimum to Maximum Values on Probability of Ticket Splitting

\begin{tabular}{lr}
\hline Variable & $\begin{array}{r}\text { Change in } \\
\text { Probability } \\
\text { of Splitting }\end{array}$ \\
\hline Perceived Party Similarities (H1) & 0.045 \\
Parliamentary Split (H2) & 0.048 \\
Sociotropic Voting (H3) & 0.090 \\
Ethnic Minorities (H4) & 0.052 \\
Campaign Meeting (H5A) & -0.036 \\
Working for a Candidate (H5B) & -0.114 \\
Education & 0.035 \\
Male & 0.015 \\
Urban & -0.003 \\
Age & 0.010 \\
Income & 0.082 \\
Radio Exposure & -0.093 \\
Television Exposure & 0.044 \\
Newspaper Exposure & 0.071 \\
\hline Note: Estimas are
\end{tabular}

Note: Estimates are derived from Model 3A holding all other variables constant at their medians.

\subsubsection{Discussion}

From the above results, it is evident that most of the variables are significant and are in the expected direction consistent with findings from similar studies on voter behavior in Ghana, on the African continent, and in other parts of the world. A couple of them, however, were surprisingly 
different from expectations. First, the perceived party similarities variable was significant in all the models with signs in the expected direction. This confirms H1 that the more voters perceive the contesting political parties to be similar, the more the likelihood of ticket splitting. Per Table 3.6 the probability of ticket splitting among persons who see no significant difference between the parties increases by (.045) when perceived party similarities variable changes from its minimum to maximum. In fact, candidates who are able to increase voter perception of party similarities by either moving closer to their opponents' issue position or move away from their party's issue position are more likely to induce ticket splitting than their counterparts who stress core party uniqueness in the political space. Thus, when parties or candidates become more similar they increase ticket splitting and in contrast, they reduce ticket splitting when they emphasize core party distinctiveness.

In my fieldwork (appendix 3.2), respondents 2 and $9^{8}$ indicated that politicians often move their policies closer to their opponent's policy position or away from their party's policy position and thereby encourage ticket splitting. For instance, when the previous government abolished teacher and nursing trainee allowances, some legislators from the president's party created scholarship schemes for their constituents. In this way, such legislators moved away from their party's position and thereby created ticket splitting. Again, when the then opposition NPP promised free senior high school, the incumbent president also promised the same and said that his government is pursuing progressive free senior high school, and therefore his government needs a renewed mandate. Thus, often when political elites adopt policies of their opponents, they are able to induce skirt and blouse voting. In other words, elite coordination (intentional act of moving away from party's position or closer to opponents' position) in the form of issue positioning can influence ticket splitting. As a result of these, in the 2016 elections there were 29 
split constituencies (constituencies with split outcome) out of 275 constituencies, the highest ever since 1996.

Second, the significance of the parliamentary split variable (H2) in all the models supports the coordination driven approach of the dissertation showing that where there is no proper cohesion between the presidential and parliamentary candidates of a political party, supporters will withdraw from the PC. Per Table 3.6, the probability of ticket splitting among persons who do not feel the same level of trust in the ruling party and president and are likely to withdraw from the $\mathrm{PC}$ of the ruling party increases by (.048) when that variable increases from its minimum to its maximum. This happens where the presidential race is most valued than the parliamentary race and also where there are intraparty conflicts that are concentrated in local areas. This finding corresponds with other studies and explains why some voters will withdraw from their PCs but vote for their presidential candidates and a PC from a different party (Boafo-Arthur 2006; Debrah and Gyampo 2013). In Ghana, like in Chile, as observed by Navia and Saldaña (2015), winning the presidency is more important to elites than winning the legislature. Therefore, party elites and party supporters attach more weight to the presidential race and so would prefer voting for their presidential candidates because the presidency is considered to be of higher level than the parliamentary race. This is in line with second-order national elections theory (Reif and Schmitt 1980) which posits that voters attach less importance to elections at the lower levels of government and therefore will prefer voting at the higher levels of government to the lower levels.

Beside the evidence from the empirical work in this chapter and the literature in support of parliamentary split (H2), the fieldwork (qualitative research) I carried out in Ghana just after the 2016 election discussed in Chapter 5 supports why some party supporters will withdraw from their PCs and vote for the presidential candidate. First, there is so much competition at the local level 
for the parliamentary race of the party and this creates internal problems. Some of my respondents revealed that most politicians prefer to be parliamentarians than holding offices that are appointment based. This is because, the political appointees, such as ministers, board chairs, as well as municipal, metropolitan and district chief executives (equivalence of mayors), do not have guaranteed tenure backed by the Constitution. The president can hire and fire any of these at any time, but the parliamentarian has a guaranteed tenure. This aside, unlike the presidency that has a two-term limit, the parliamentarian can be in office as long as the people are willing to renew his or her mandate. This makes the competition for the parliamentary nomination very competitive and acrimonious even within the same political party. Additionally, due to their work, the parliamentarians are "distanced" from their constituencies most of the time. Their in-party competitors who are political appointees of the president such as the municipal, metropolitan and district chief executives are stationed among the people and carry out development projects and therefore easy to win the hearts of the electorates. Some of these, at times sabotage the parliamentarians just to take over their positions. Second, respondent 6 revealed that some of the parliamentarians, before or after they get to office, involve themselves in local conflicts such as chieftaincy and ethnic conflicts 9 . These conflicts are locally centered and therefore, the local politicians suffer for them. These and other factors account for why some party elites and supporters of a party may withdraw from their PCs and even at times may openly and secretly campaign against the PCs. It is also important to note that, though supporters often withdraw from the PC in support of the presidential candidate, in my fieldwork it came to light that at times, the reverse can be true. Respondents 2 and 9 alluded to the fact that government policy that abolished teacher and nursing trainee allowances caused some PCs from the president's party who established scholarship schemes to receive more votes while the president lost in some of these 
constituencies $^{8}$. Thus, supporters may withdraw from the president and support the PC due to differences in policies.

Third, the study confirms hypothesis H4 represented by the ethnic minority variable which was statistically significant in all four models it appeared and in the expected direction. The probability of ethnic minorities splitting increases by (.052) among ethnic minorities when that variable is changed from its minimum to its maximum. This finding is supported by discoveries from similar studies on Ghana. For instance, scholars such as Adu-Amankwaah (2008), Debrah (2016), and Frempong (2001) found that ethnicity is not used for clientelistic purposes in Ghana especially among minority ethnic groups. Contrary to Horowitz (1985), voting among Ghanaian ethnic communities is not a mere headcount of membership. In fact, most voters only vote for their coethnics when they had performed well or expected to do better than non-coethnics (AduAmankwaah 2008; Debrah 2016; Frempong 2001). It was for this reason that former President Dr. Hilla Limann lost the 1992 election in his own home district and Vice-President Prof. Atta Mills lost the 2000 and the 2004 elections (also in his home turf) to their competitors who were considered more viable candidates (Adu-Amankwaah 2008; Frempong 2001).

Respondent 2 indicated in an interview that the reason why ethnicity is not too much an issue in Ghana is that, the two major parties, NPP and NDC, do their best to nominate candidates from the predominant ethnic groups in each constituency and get the minor ethnic groups to support them ${ }^{11}$. Thus, elite coordination is at work here. Therefore, splitting is often based on candidate quality and whether or not there are intraparty conflicts in the various parties. One of my respondents said that, “...in Akan land all the candidates are Akan and in Ewe land all the candidates are Ewes. Moreover, the presidential candidates of the two major political parties are often very experienced who have been in politics for decades and are known beyond and within 
Ghana. Therefore, competence rather than ethnicity is responsible for splitting"9. These views notwithstanding, ethnicity cannot be discounted in Ghana when it comes to voter choice. For instance, the current National Chairman of the NDC (the major national opposition party), during my interview with him, said, "Some communities such as the Kokombas will always want to vote for a Kokomba irrespective of the party the person belongs to" $" 11$ These contrasting views on ethnicity notwithstanding, ethnicity is a mobilizing force and a mechanism that communicates to the electorates the viable candidates in that locality. If the viable candidates are from the same party, there will likely be less ticket splitting. However, where the viable candidates are from different parties, then, the likelihood of splitting increases. Thus, ethnicity is a voter coordination tool that creates splitting or otherwise depending on the direction the coordination takes especially among ethnic minorities.

Fourth, the variable, working for a candidate was significant in all the models and the signs were in the expected direction. From Table 3.6, the probability for persons who work for candidates to split reduces by (.114) when the variable, work for candidate, is changed from its minimum to its maximum. This shows that persons who work for candidates are less likely to engage in ticket splitting. These people are often influenced by candidates they work with and therefore less likely to split their ticket. This finding is consistent with what other scholars such as Burden and Kimball (1998, 2009) and Roscoe (2003) who studied American ticket splitters found. These scholars found persons who work for candidates to less engage in ticket splitting.

Fifth, though the economic voting variable, sociotropic voting (H3) was not significant in all the models especially when missing values were replaced, its significance in Models $2 \mathrm{~A}$ and 3A is consistent with previous work on Ghana. Some of these studies found that a president's economic performance impacts his reelection or his party's chances in the next elections (Debrah 
2016; Lindberg 2013). Boafo-Arthur (2006) and Ninsin (2006a, 2006b) also found that Ghanaian electorates have sayings such as "Hwe w'asitena mu na to aba pa", which simply means that "examine your life and vote appropriately". Thus, like their counterparts elsewhere, Ghanaian electorates are capable of using evaluative variables such as government's economic performance to split their tickets. They will vote for a president who pursues policies that create economic prosperity and if the PC from the president's party is not responsive to the electorates, they will vote against that PC and this will create ticket splitting. Thus, through economic voting, voter coordination can lead to splitting when an incumbent president's economic performance is at stake.

Finally, the demographic and socioeconomic variables were not that significant as in other studies. Only income was partially significant in just one (Model 3A) out the four models that demographic variables were used in the regression analyses. The political information variables; radio, television and newspaper exposure present interesting findings. First, radio exposure has been significant in all the models but was not in the expected direction as per Tables 3.4 and 3.5 above. Per Table 3.6, the probability of splitting is reduced by (0.93) among persons who listen to radio daily when radio exposure variable was changed from its minimum to its maximum value. This suggests that ticket splitters might be listening to radio stations that match their political biases or relay messages against ticket splitting. Newspaper exposure was only significant in Model 1A while Television exposure was significant in Models 3A and 3B when all the variables were combined in the models. Based on the performance of the political information variables (radio exposure's signs were not in the expected direction; newspaper exposure and television exposure were significant in few models), it could be said that their effects are largely inconsistent as shown by many other scholars (Atwood and Sanders 1975; Beck et al. 1992; Bybee et al. 1981). Due to their inconsistent relationship with ticket splitting, it stands to reason that they could be tools used 
by elites to disseminate public opinion in vogue at the time of an election to influence voter choice in certain direction (Chandra 2007, 2009; Mclaughlin 2008). It will be fascinating to investigate the instrumental role of political information, especially, radio exposure on ticket splitting. It is likely that the direction of political information variables may largely depend on the objectives of those who employ them.

In fact, it would have been great to investigate voter coordination in more nuanced ways where it may lead to less ticket splitting rather than more ticket splitting. For instance, in a given constituency, parties A and B presented candidates for the presidential race and a voter prefers party A's candidate in that contest. Now, assuming in the legislative race parties A, B, and C presented candidates and the same voter prefers $\mathrm{C}$ to $\mathrm{A}$ to $\mathrm{B}(\mathrm{C}>\mathrm{A}>\mathrm{B})$, if that voter does not think $\mathrm{C}$ is viable and therefore, votes for $\mathrm{A}$ instead of $\mathrm{C}$, in that case, voter coordination would lead to less ticket splitting. This scenario could have been possible if the Afrobarometer dataset had data on expected candidate preference prior to the elections and actual voting decision after the elections. Again, my data does not allow me to identify which parties fail to coordinate. Q90B would have been a good example from the data to address an instance where the Nkrumahist parties: Convention People's Party (CPP), People's National Convention (PNC), Progressive People's Party (PPP), Democratic People's Party (DPP), and Great Consolidated Popular Party (GCPP) failed to coordinate by presenting five candidates. However, because I used that question to deduce my likely ticket splitters (my dependent variable), I could not use the same question to generate an independent variable. In the light of this limitation, the next two chapters employed different datasets (constituency electoral dataset for chapter four and fieldwork survey data for chapter five) to complement findings from this chapter. 
Samuel K. Darkwa

\subsection{CONCLUSION}

In sum, ticket splitting at the individual level is necessary to evaluate why some voters do split their ticket and others do not. In this way, we can also predict possible ticket splitters, all things being equal. Some scholars have, however, cast doubt on the individual-level variables on the basis that it is possible for two people to be identical in many of the individual-level variables, yet one splits, and the other does not (Burden and Kimball 2009; Roscoe 2003). Indeed, this points to other variables beyond the individual level but that does not stop us from explaining why for instance, weak partisans would split, and strong partisans would not. We are also better disposed to understand why elite miscoordination can lead even strong partisans to split in certain contexts. We are also better disposed to understand why some politicians will like to induce ticket splitting through issue positioning by moving closer to their opponents' issue position or away from their party issue position. Again, we are able to understand why some politicians in an MP's party will care less in advocating skirt and blouse because such politicians may prefer the MP's office for which tenure is guaranteed by the constitution.

This section has given us a bigger picture to consider in analyzing individual level variables that impact ticket splitting and this is in line with Burden and Helmke (2009) who argue that the focus of ticket splitting will expand beyond its consideration in an American setting when we study the phenomenon on comparative basis. We can understand why, for instance, the presidential race is very important to the Ghanaian electorates and their political actors to the extent that some supporters of a political party would like to vote for their presidential candidate and for a PC from another party. This same point can be understood when viewed from an American perspective by employing Burden and Kimball (2009). From Burden and Kimball (2009), we understand that at least the two dominant parties in America are able to attract high profile individuals for the 
presidential race but the same thing cannot be said about legislative candidates in many cases. Consequently, many will vote for their presidential candidate and for other party's candidate in the legislative race, as the candidate from one's own party may be weak.

If America, the oldest democracy, is faced with such a challenge (subpar candidates) at the constituency level (electoral district) that causes voters to split their ticket (Burden and Kimball 2009), then Ghana is not likely to be an exception. Ghana is also faced with a similar challenge, especially given that the coordination problem at the constituency level is bigger; ticket splitting may be endemic at that level. Finally, if we need to study ticket splitting beyond the American setting, then we can understand why ethnicity becomes a tool for communicating viable candidates in a voting district rather than engaging in clientelistic voting. It can be said that ethnicity in Ghana is not for clientelistic purposes because a number of big politicians have lost the elections in their home turf to their opponents. For instance, former President Dr. Hilla Limann lost the 1992 elections to Mr. Jerry Rawlings in his own region (Adu-Amankwaah 2008; Frempong 2001). Again, Vice-President Prof. Atta Mills lost the 2000 elections to candidate Kufuor and also in 2004 to President Kufuor both in Prof. Mills' home town (Adu-Amankwaah 2008; Frempong 2001).

It has been argued that factors that induce ticket splitting are very diverse and no single study can unearth all of them (Burden and Helmke 2009). This chapter has therefore focused on how elite (mis)coordination encourages voter coordination that often induces ticket splitting because voters would like their votes to count (Cox 1997, 1999) and therefore, would like to withdraw support from less viable candidates. In the same way that demographic, socioeconomic, attitudinal variables, and political information variables are important in explaining ticket splitting at the individual level, voter coordination in its nuance and complexity is required to understand 
the phenomenon at the individual level. Ticket splitting at the individual level can be viewed from multiple angles so long as its focus is on the individual action at the voting booth.

In effect, the chapter has made three important points. First, it has reclassified skirt and blouse voting into skirt and blouse voting (split-ticket voting) and skirt and blouse outcome (split district outcome). Previously, the concept was plagued with conceptual ambiguity where the same concept had two usages. The chapter has reclassified skirt and blouse voting to enable the Ghanaian concept to be comparable to similar concepts in political science. Second, ticket splitting at the individual level can be studied from voter coordination perspective. That is looking at how voters make sense of the options available to them in an election to make the most electoral decision bearing in mind that voters want their votes to count (Chandra 2007, 2009; Cox 1997, 1999). Finally, though ticket splitting was certainly not one of the objectives of the Afrobarometer in its data collection, collecting data on it will help advance the comparative study of African politics because other barometers do that. That is, the chapter recommends that the administrators of Afrobarometer dataset should try to incorporate questions that assess voter intentions such as ticket splitting in their data collection. Again, the dataset could not allow the examination of how voter coordination could lead to less ticket splitting. Furthermore, the dataset does not allow me to distinguish which parties fail to coordinate.

\subsection{REFERENCES}

Abramson, Paul R. 1983. Political Attitudes in America: Formation and Change. New York: Freeman.

Adu-Amankwaah, Bernard. 2008. Ethnic Politics and Its Potential for Conflict: A Ghanaian Perspective. Master's thesis, Political Science Department, University of Oslo.

Asunka, Joseph. 2016. "Partisanship and Political Accountability in New Democracies: Explaining Compliance with Formal Rules and Procedures in Ghana." Research \& Politics 3.1.

Atwood, L. Erwin, and Keith R. Sanders. 1975. "Perception of Information Sources and Likelihood of Split-Ticket Voting.” Journalism Quarterly 52.3: 421-428. 
Banducci, Susan A., Todd Donovan, and Jeffrey A. Karp. 2004. "Minority Sepresentation, Empowerment, and Participation." The Journal of Politics 66.2 (2004): 534-556.

Bawn, Kathleen. 1999. "Voter Responses to Electoral Complexity: Ticket Splitting, Rational Voters and Representation in the Federal Republic of Germany." British Journal of Political Science 29.3: 487-505.

Beck, Paul Allen, Lawrence Baum, Aage R. Clausen, and Charles E. Smith, Jr. 1992. "Patterns and Sources of Ticket Splitting in Subpresidential Voting." American Political Science Review 86:916-28.

Benoit, Kenneth, Daniela Giannetti, and Michael Laver. 2006. "Voter Strategies with Restricted Choice Menus.” British Journal of Political Science 36.3: 459-485.

Benoit, Kenneth. 2001. "Two Step Forward, One Steps Back: Electoral Coordination in the Hungarian Elections of 1998." Typescript. Trinity College, Dublin.

Benton, Allyson Lucinda. 2005. "Dissatisfied Democrats or Retrospective Voters? Economic Hardship, Democratic Accountability.” Annual Review of Political Science 10: 271-96.

Birch, Sarah. 2003. Electoral systems and political transformation in post-communist Europe. Springer.

Blais, André, Peter Loewen, and Marc André Bodet. 2004. Strategic Voting”. In Jack Vowles (ed.) Voters' Veto: the 2002 Election in New Zealand and the Consolidation of Minority Government. Auckland University Press.

Boafo-Arthur, Kwame. 2006. "The 2004 General Elections: An Overview”, In Boafo-Arthur, ed., Voting for Democracy in Ghana: The 2004 Elections in Perspective, Vol. 1. Accra: Freedom Publications, pp. 33-58.

Boafo-Arthur, Kwame. 2008. Democracy and Stability in West Africa: the Ghanaian Experience. Nordiska Afrikainstitutet; Department of Peace and Conflict Research, Uppsala University.

Bratton, Michael. 2004. “The Alternation Effect in Africa.” Journal of Democracy 15.4: 147-158.

Brunell, Thomas L., and Bernard Grofman. 2009. "Testing Sincere Versus Strategic Split-Ticket Voting at the Aggregate Level: Evidence from Split House-President Outcomes, 1900-2004." Electoral Studies 28.1: 62-69.

Burden, Barry C. 2009. "Candidate-Driven Ticket Splitting in the 2000 Japanese Elections." Electoral Studies 28.1: 33-40.

Burden, Barry C., and David C. Kimball. 1998. "A New Approach to the Study of Ticket Splitting." American Political Science Review 92:533-44.

Burden, Barry C., and David C. Kimball. 2009. Why Americans Split their Tickets: Campaigns, Competition, and Divided Government. University of Michigan Press.

Burden, Barry C., and Gretchen Helmke. 2009. "The Comparative Study of Split-Ticket Voting." Electoral Studies 28.1: 1-7. 
Burnham, Walter Dean. 1965. "The changing shape of the American political universe." American Political Science Review 59.1: 7-28.

Bybee, Carl R., et al. 1981. "Mass Communication and Voter Volatility." Public Opinion Quarterly 45.1: 69-90.

Campbell, Angus, and Warren E. Miller. 1957. "The motivational basis of straight and Split-Ticket Voting." American Political Science Review 51.2: 293-312.

Campbell, Angus, Philip E. Converse, Warren E. Miller, and E. Donald. 1960. The American Voter University of Chicago Press

Chandra, Kanchan. 2007. Why Ethnic Parties Succeed: Patronage and Ethnic Head Counts in India. Cambridge University Press, 2007.

Chandra, Kanchan. 2009. "Why Voters in Patronage Democracies Split their Tickets: Strategic Voting for Ethnic Parties." Electoral Studies 28.1: 21-32.

Converse, Philip E. 1964. "The Nature of Belief Systems in Mass Publics". In David Apter. Ideology and Discontent. New York: Free Press.

Cox, Gary W. 1997. Making Votes Count: Strategic Coordination in the World's Electoral Systems. Cambridge University Press.

Cox, Gary W. 1999. "Electoral rules and electoral coordination." Annual Review of Political Science 2.1: 145-161.

Cummings, Milton C., Jr. 1966. Congressmen and the Electorate: Elections for the U.S. House and the President, 1920-1964. New York: Free Press.

Daddieh, Cyril. 2011. "Democratic Consolidation Without a Second Turnover: Ghana's Remarkable 2004 Elections.” In Abdoulaye Saine, Boubacar N'Diaye, and Mathurin Houngnikpo (eds.) Elections and Democratization in West Africa 1990-2009. Trenton, New Jersey: Africa World Press.

Dalton, Russell J. 2013. The Apartisan American: Dealignment and Changing Electoral Politics. CQ Press, 2013.

De Vries, Walter, and V. Lance Tarrance. 1972. The Ticket-Splitter: A New Force in American Politics. Grand Rapids: Eerdmans.

Debrah, Emmanuel, and Ransford Edward Van Gyampo. 2013. "The Youth and Party Manifestos in Ghanaian Politics-The Case of the 2012 General Elections." Journal of African Elections 12.2: 96-114.

Debrah, Emmanuel. 2004. "The politics of elections: opposition and incumbency in Ghana's 2000 elections." Africa Insight 34.2-3: 3-15.

Debrah, Emmanuel. 2016. "The Ghanaian Voter and the 2008 General Election." Politikon 43.3: 371-387.

Downs, Anthony. 1957. An Economic Theory of Democracy. New York: Addison Wesley 
Duverger, Maurice. 1954. Political Parties: Their Organization and Activity in The Modern State. London: Methuen.

Feigert, Frank B. 1979. “Illusions of Ticket Splitting.” American Politics Quarterly 7.4: 470-488.

Ferrara, Federico, Erik Herron, and Misa Nishikawa. 2005. Mixed electoral systems: Contamination and its consequences. Springer.

Fiorina, Morris P. 1988. "The Reagan Years: Turning Toward the Right or Groping Toward the Middle?" In Barry Cooper, Allan Komberg, and William Mishler (eds.) The Resurgence of Conservatism in Anglo-American Democracies. Durham, NC: Duke University Press.

Fiorina, Morris P. 1996. Divided Government, Second Ed. Allyn \& Bacon, Needham Heights, MA.

Frempong, Alexander Kaakyire Duku. 2001. "Ghana's Election 2000: The Ethnic Undercurrent." In Joseph Ayee (ed.) Deepening Democracy in Ghana: Politics of the 2000 Elections, Vol. 1. Accra: Freedom Publications.

Frempong, Alexander Kaakyire Duku. 2012. Electoral Politics in Ghana's Fourth Republic: In the Context of Post-Cold War Africa. Accra: Freedom Publication.

Frempong, Alexander Kaakyire Duku. 2017. Elections in Ghana: 1951 - 2016. Digibooks Ghana Ltd.

Fridy, Kevin S. 2006. "The Elephant, Umbrella, and Quarrelling Cocks: Disaggregating Partisanship in Ghana's Fourth Republic.” African Affairs 106.423: 281-305.

Fry, Lincoln. 2013. "Trust of the Police in South Africa: A Research Note." International Journal of Criminal Justice Sciences 8.1: 36.

Golder, Sona Nadenichek. 2006. The logic of pre-electoral coalition formation. Ohio State University Press.

Gomez, Brad T., and J. Matthew Wilson. 2006. "Cognitive Heterogeneity and Economic Voting: A Comparative Analysis of Four Democratic Electorates." American Journal of Political Science 50(1): 127-145.

Gschwend, Thomas, Ron Johnston, and Charles Pattie. 2003. "Split-ticket Patterns in MixedMember Proportional Election Systems: Estimates and Analyses of their Spatial Variation at the German Federal Election, 1998.” British Journal of Political Science 33.1: 109-127.

Guinjoan, Marc. 2016. Parties, elections and electoral contests: Competition and contamination effects. Routledge.

Helmke, Gretchen. 2009. "Ticket-Splitting as Electoral Insurance: The Mexico 2000 Elections." Electoral Studies 28.1: 70-78.

Herron, Erik S., and Misa Nishikawa. 2001. "Contamination Effects and the Number of Parties in Mixed-Superposition Electoral Systems.” Electoral Studies 20.1: 63-86. 
Herron, Erik S., Kuniaki Nemoto, and Misa Nishikawa. 2018. "Reconciling Approaches in the Study of Mixed-Member Electoral Systems." In Erik S. Herron, Robert J. Pekkanen, and Matthew Soberg Shugart (eds.). Oxford Handbook of Electoral Systems. Oxford: Oxford University Press.

Horowitz, Donald L. 1985. Ethnic Groups in Conflict. University of California Press Berkeley.

Hyden, Goran, and Colin Leys. 1972. "Elections and Politics in Single-Party Systems: The Case of Kenya and Tanzania.” British Journal of Political Science 2.4: 389-420.

Ichino, Nahomi, and Noah L. Nathan. 2013. "Do Primaries Improve Electoral Performance? Clientelism and Intra-Party Conflict in Ghana." American Journal of Political Science 57.2: 428441.

Ichino, Nahomi, and Noah L. Nathan. 2017. "Primary Elections in New Democracies: The Evolution of Candidate Selection Methods in Ghana."

Kadima, Denis, and Cassam Uteem. 2006. The politics of party coalitions in Africa. EISA.

Karp, Jeffrey A. 2009. "Candidate Effects and Spill-Over in Mixed Systems: Evidence from New Zealand." Electoral Studies 28.1: 41-50.

Karp, Jeffrey A., et al. 2002. "Strategic Voting, Party Activity, and Candidate Effects: Testing Explanations for Split Voting in New Zealand's New Mixed System.” Electoral Studies 21.1: 122.

Kedar, Orit, 2005. "When Moderate Voters Prefer Extreme Parties: Policy Balancing in Parliamentary Elections.” American Political Science Review 99, 185-199.

Key, Valdimer Orlando, and Milton Curtis Cummings. 1966. The Responsible Electorate: Rationality in Presidential Voting, 1936-1960, [by] VO Key, with the Assistance of Milton C. Cummings; Foreword by Arthur Maass. Harvard University Press.

Kinder, Donald R. 1983. "Diversity and complexity in American Public Opinion." Political Science: The state of The Discipline: 389-425.

Kollman, Ken. 2018. "Election data and levels of analysis." In Erik S. Herron, Robert J. Pekkanen, and Matthew S. Shugart (eds.) The Oxford Handbook of Electoral Systems: 405-423. Oxford University Press

Lachat, Romain. 2007. A Heterogeneous Electorate: Political Sophistication, Predisposition Strength, and the Voting Decision Process. Vol. 7. Baden-Baden: Nomos.

Lemarchand, Rene, and Keith Legg. 1972. "Political Clientelism and Development: a Preliminary Analysis." Comparative politics 4.2: 149-178.

Lemarchand, René. 1972. "Political Clientelism and Ethnicity in Tropical Africa:" Competing Solidarities in Nation-Building." American political science review 66.1: 68-90.

Lindberg, Staffan I. 2013. "Have the Cake and Eat it: The Rational Voter in Africa." Party Politics 19.6: $945-961$.

Maddox, William S., and Dan Nimmo. 1981. "In Search of the Ticket Splitter." Social Science Quarterly 62.3: 401. 
McFadden, Daniel. 1974. "Frontiers in Econometrics, chapter Conditional logit analysis of qualitative choice behavior."

McFadden, Daniel. 1977. Quantitative Methods for Analyzing Travel Behavior of Individuals: Some Recent Developments. Berkeley: Institute of Transportation Studies, University of California.

Mclaughlin, Eric S. 2008. "Racial, Ethnic or Rational Voters? Splitting Tickets in South Africa." Politikon 35.1: 23-41.

Navia, Patricio, and José Luis Saldaña. 2015. "Mis-Coordination and Political Misalignments in Ticket-Splitting: The Case of Chile, 2005-2009. “Contemporary Politics 21.4: 485-503.

Network, Afrobarometer. 2014. "Afrobarometer Round 6 Survey Manual."

Neuman,W. Russell. 1986. The Paradox of Mass Politics. Cambridge, Mass.: Harvard University Press.

Ninsin, Kwame A. 2006a. Political Parties and Political Participation in Ghana. KAS, 2006.

Ninsin, Kwame A. 2006b. "Introduction: The Contradictions and Ironies of Elections in Africa." Africa development 31.3: 1-10.

Osei, Anja. 2012. Party-Voter Linkage in Africa: Ghana and Senegal in Comparative Perspective. Springer Science \& Business Media.

Page, Benjamin I. 1978. "Choices and Echoes in Presidential Elections: Rational Man and Electoral Democracy."

Petrocik, John R. 1991 "Divided Government: Is it All in the Campaigns?" The politics of Divided Government: 13-38.

Petrocik, John R., and Joseph Doherty. 1996. "The Road to Divided Government: Paved without Intention." In Peter F. Galderisi (ed.) Divided Government: Change, Uncertainty, and the Constitutional Order. Lanham, MD: Rowman and Littlefield.

Popkin, Samuel L. 1991. The Reasoning Voter: Communication and Persuasion in Presidential Campaigns. Chicago: University of Chicago Press.

Powell, G. Bingham and Guy D. Whitten. 1993. "A Cross-National Analysis of Economic Voting: Taking Account of the Political Context." American Journal of Political Science 37:391-414.

Rallings, Colin, and Michael Thrasher. 2003. "Explaining Split-Ticket Voting at the 1979 and 1997 General and Local Elections in England.” Political Studies 51.3: 558-572.

Reif, Karlheinz, and Hermann Schmitt. 1980. "Nine Second-Order National Elections-A Conceptual Framework for the Analysis of European Election Results." European Journal of Political Research 8.1: 3-44.

Rich, Timothy S. 2014. "Split-Ticket Voting in South Korea's 2012 National Assembly Election”. Asian Politics \& Policy-Volume 6, Number 3-Pages 455-469 
Roscoe, Douglas D. 2003. "The Choosers or the Choices? Voter Characteristics and the Structure of Electoral Competition as Explanations for Ticket Splitting." Journal of Politics 65.4: 11471164.

Shugart, Matthew, and Martin P. Wattenberg. 2001. Mixed-Member Electoral Systems: The Best of Both Worlds? Oxford University Press.

StataCorp, L. P. 2017. "Stata Multiple-Imputation Reference Manual Release 15." Texas: Stata Press

Tavits, Margit. 2008. "On the Linkage Between Electoral Volatility and Party System Instability in Central and Eastern Europe.” European Journal of Political Research 47.5: 537-555.

Thrasher, Michael, et al. 2014. "Voting Systems in Parallel and the Benefits for Small Parties: An Examination of Green Party Candidates in London Elections." Party Politics 20.1: 134-142.

Weghorst, Keith R., and Staffan I. Lindberg. 2013. "What Drives the Swing Voter in Africa?" American Journal of Political Science 57.3: 717-734.

Zaller, John. 1992. The Nature and Origins of Mass Opinion. New York: Cambridge University Press.

\subsection{NOTES}

1. As we shall soon see, MCTS is what has come to bedevil the Ghanaian political actors since the inception of the Fourth Republican Constitution in 1992 and especially the Nkrumahist Tradition which has many splinter groups contesting each of the seven elections since 1992.

2. The Afrobarometer project is a joint enterprise of "the Center for Democratic Development (CDD) in Ghana, the Institute for Justice and Reconciliation (IJR) in South Africa, the Institute for Development Studies (IDS) at the University of Nairobi in Kenya, and the Institute for Empirical Research in Political Economy (IREEP) in Benin. Michigan State University (MSU) and the University of Cape Town (UCT) provide technical support to the network" (Network Afrobarometer 2014, 2).

3. Sociotropic evaluation addresses the question of how economics influences politics. That is, voters consider the general economic condition of a country to make their voting decisions Kinder and Kiewiet $(1979 ; 1981)$. Thus, when economic conditions are good, voters are likely to vote for the incumbent president for presiding over a prosperous economy and punish incumbents when general economic conditions are bad. Sociotropic evaluation which focuses on the economic condition of the nation is contrasted with egocentric evaluation (pocketbook voting) which asserts that voters make their voting decisions by looking at their personal financial situation at the time of the election.

4. The Ghanaian Constitution prohibits the formation of political parties on ethnic lines or on regional bases and requires all political parties to have functional offices in all the constituencies. However, research findings reveal that the two major parties, the NPP and the NDC have their main support from Akan and Ewe ethnic groups respectively (Ayee 2002; Debrah 2016; Frempong 2017; Fridy 2006) and therefore, are more likely to vote straight ticket. Other ethnic groups on the 
other hand, are more likely to split their votes (Adu-Amankwaah 2008; Debrah 2016; Frempong 2001; Fridy 2006). In short, I expect more ticket splitting from other ethnic groups than Akan and Ewe but elite coordination is likely to influence voting choice of ethnic members.

5. I am grateful to Professor Mason Moseley and Professor Erik Herron who suggested the multiple imputation technique to me to handle missing data in this dissertation.

6. The dataset I used had a lot of missing values. To ensure that missing data do not affect my results, multiple imputation techniques were adopted to replace missing values. After this, I rerun the binary logit regression to compare the regression results from the dataset with missing values with those from replaced missing values

7. Standard measure of fit cannot be calculated for multiple imputation technique model. Per Stata Multiple-Imputation Reference Manual Release 15, standard measure of fit does not work with models estimated using multiple-Imputation technique.

8. Interview with Deputy Director of Operations, National Commission for Civic Education (NCCE) Ghana on Wednesday, March 8, 2017 and with the Director of Research to the main opposition NDC on Wednesday, March 15, 2017 by author.

9. Interview with National Civic Society leader on Monday, March 13, 2017 by author.

10. Interview with Deputy Director of Operations, National Commission for Civic Education (NCCE) Ghana on Wednesday, March 8, 2017 by author.

11. Interview with the Director of Elections (currently the National Chairperson) to the main opposition NDC on Wednesday, March 15, 2017 and with the Achimota Zonal Chairperson of the ruling NPP on Wednesday, March 8, 2017 by author.

\section{Appendix 3.1: Description of the variables}

\begin{tabular}{|l|l|l|}
\hline Indicator & $\begin{array}{l}\text { Description of the Variable (questions in } \\
\text { the 2015 Afrobarometer Survey) }\end{array}$ & Model 1 Coding Rule \\
\hline $\begin{array}{l}\text { Split-ticket } \\
\text { voting }\end{array}$ & $\begin{array}{l}\text { Q90. Do you feel close to any particular } \\
\text { political party? } \\
\text { Q99. If presidential elections were held } \\
\text { tomorrow, which party's candidate would } \\
\text { you vote for? }\end{array}$ & $\begin{array}{l}\text { Binary: 1= those who do not feel the same } \\
\text { level of closeness to the political party and } \\
\text { presidential candidates of that party } \\
0=\text { otherwise }\end{array}$ \\
\hline $\begin{array}{l}\text { Perceived } \\
\begin{array}{l}\text { Sarty } \\
\text { (Similarities } \\
\text { between } \\
\text { Parties) }\end{array}\end{array}$ & $\begin{array}{l}\text { Q62. Which of the following do you see as } \\
\text { the most important difference between the } \\
\text { ruling party and opposition parties in Ghana? }\end{array}$ & $\begin{array}{l}\text { Binary: 1=There is no difference; 0=otherwise } \\
\text { (the honesty or integrity of party leader; the } \\
\text { religion of party leaders or member; their } \\
\text { economic and development policies; the } \\
\text { experience of party leaders; the ethnicity of } \\
\text { party leaders or members; the personalities of } \\
\text { party leaders; the regional identity of party } \\
\text { leaders; None of these) }\end{array}$ \\
\hline
\end{tabular}




\begin{tabular}{|c|c|c|}
\hline $\begin{array}{l}\text { Parliamentary } \\
\text { split: }\end{array}$ & $\begin{array}{l}\text { Q52A. How much do you trust each of the } \\
\text { following, or haven't you heard enough } \\
\text { about them to say: The President? Q52F. } \\
\text { How much do you trust each of the } \\
\text { following, or haven't you heard enough } \\
\text { about them to say: The Ruling Party? }\end{array}$ & $\begin{array}{l}\text { Binary: } 1=\text { Those who do not feel the same } \\
\text { level of trust in the ruling party and president; } \\
0=\text { otherwise }\end{array}$ \\
\hline $\begin{array}{l}\text { Sociotropic } \\
\text { (Economic } \\
\text { Voting) }\end{array}$ & $\begin{array}{l}\text { Q4A. In general, how would you describe: } \\
\text { The present condition of this country? }\end{array}$ & $\begin{array}{l}\text { Scale: } 1=\text { Very bad; } 2=\text { Fairly bad; } 3=\text { either } \\
\text { good nor bad; 4=Fairly Good; 5=Very good }\end{array}$ \\
\hline $\begin{array}{l}\text { Ethnic } \\
\text { minorities }\end{array}$ & $\begin{array}{l}\text { Q87. What is your ethnic community, } \\
\text { cultural group or tribe? }\end{array}$ & Binary: $1=$ others; $0=$ Akan and Ewe/Anglo \\
\hline $\begin{array}{l}\text { Campaign } \\
\text { meetings }\end{array}$ & $\begin{array}{l}\text { Q23B. Thinking about the last national } \\
\text { election in 2012, did you: Attend a meeting } \\
\text { with a candidate or campaign staff? }\end{array}$ & $\begin{array}{l}\text { Binary: } 1=\text { Yes; } 0=\text { No } \\
\text { Weak partisans will split }\end{array}$ \\
\hline $\begin{array}{l}\text { Work for } \\
\text { candidate }\end{array}$ & $\begin{array}{l}\text { Q23D. Thinking about the last national } \\
\text { election in 2012, did you: Work for a } \\
\text { candidate or party? }\end{array}$ & $\begin{array}{l}\text { Binary: } 1=\text { Yes; } 0=\text { No } \\
\text { Weak partisans will split }\end{array}$ \\
\hline Education & $\begin{array}{l}\text { Q97. What is your highest level of } \\
\text { education? }\end{array}$ & $\begin{array}{l}\text { Scale: } 0=\text { No formal schooling; } 1=\text { Informal } \\
\text { schooling only; } 2=\text { Some primary schooling; } \\
3=\text { Primary school completed; } 4=\text { Some } \\
\text { secondary school; } 5=\text { Secondary school } \\
\text { completed; } 6=\text { Post-secondary qualifications; } \\
7=\text { Some university; } 8=\text { University completed; } \\
9=\text { Post-graduate }\end{array}$ \\
\hline Male & Q101. What is your gender? & Binary: $1=$ male $0=$ female \\
\hline Urban & Urban or rural primary sampling unit & Binary: $0=$ rural; $1=$ urban \\
\hline Age & Q1. How old are you? & $\begin{array}{l}\text { Continuous variable: age of respondents was } \\
\text { taken as given }\end{array}$ \\
\hline Income & $\begin{array}{l}\text { Q8E. Over the past year, how often, if ever, } \\
\text { have you or anyone in your family: Gone } \\
\text { without a cash income? }\end{array}$ & $\begin{array}{l}\text { Scale: } 0=\text { Never; } 1=\text { Just once or twice; } \\
2=\text { Several times; } 3=\text { Many times; } 4=\text { Always }\end{array}$ \\
\hline TV Exposure & $\begin{array}{l}\text { Q12B. How often do you get news from the } \\
\text { following sources: Television? }\end{array}$ & $\begin{array}{l}\text { Binary: } 1=\text { Everyday } \\
0=\text { otherwise }\end{array}$ \\
\hline $\begin{array}{l}\text { Radio } \\
\text { Exposure }\end{array}$ & $\begin{array}{l}\text { Q12A. How often do you get news from the } \\
\text { following sources: Radio? }\end{array}$ & $\begin{array}{l}\text { Binary: } 1=\text { Everyday } \\
0=\text { otherwise }\end{array}$ \\
\hline $\begin{array}{l}\text { Newspaper } \\
\text { Exposure }\end{array}$ & $\begin{array}{l}\text { Q12C. How often do you get news from the } \\
\text { following sources: Newspapers? }\end{array}$ & $\begin{array}{l}\text { Binary: } 1=\text { Everyday } \\
0=\text { otherwise }\end{array}$ \\
\hline
\end{tabular}

\section{Appendix 3.2: Fieldwork}

The fieldwork took place in Ghana in March 2017, covering seven out of the 275 constituencies with 303 respondents. Most respondents were contacted between Sunday, March 5, 2017 and Friday, March 17, 2017. One person elected to have his interview via Skype on Friday, March 24, 2017. The 303 participants were essentially party elites with just a handful of them representing civil society, the media, and members of academia. 
Prior to administering the questionnaires, pilot samples were run with colleagues that have the same level of involvement in the subject area in the United States. Their constructive feedback and critiques enriched the final questionnaire. Again, the pilot survey was carried out in Ghana among a subset of the selected sample whose response led to rewording of some of the questions to reflect the level of comprehension of the project's research subjects. Thus, efforts were made to ensure that the questions and the design work as intended were not ambiguous and that respondents were asked the right questions to measure key variables. It worth pointing out that prior to administering the questionnaires, all the committee members made inputs to the questionnaires. Professor Mason Moseley for instance, tremendously helped in finetuning the survey before in Ghana finishing touches were made to reflect the language and comprehension levels of the average Ghanaian research respondents. What the fieldwork entails could be summed up under four main headings below.

\section{A. Time and location of the interviews}

As indicated above, the fieldwork took place in Ghana between Sunday, March 5, 2017 and Friday, March 17, 2017 involving seven electoral districts (constituencies). The seven constituencies selected were Ablekuma South, Bantama, Ellembelle, Evalue Ajomoro Gwira, Ketu South, Klottey Korle, and Wulensi. The selection criterion for the constituencies was to help sample those that have experienced skirt and blouse outcome(s) and those that have not as well as constituencies where interparty alliance had taken place and those where interparty alliance had never taken place before. The sample was also to include cosmopolitan and non-cosmopolitan constituencies, swing constituencies and party strongholds, huge population size ${ }^{1}$ (with 60,000 or more voters) and those with less than 60,000 voters. Finally, consideration was given to constituencies where a former party affiliated candidate who protested by going independent won and where no former party affiliated candidate who protested by going independent won. The number of constituencies involved, and the selection criteria is summarized in Table 1 below.

Table 1: Cases (constituencies) and their Fitness to the Selection Criteria

\begin{tabular}{|c|c|c|c|c|c|c|c|c|}
\hline Constituency & $\begin{array}{l}\text { Skirt \& } \\
\text { blouse } \\
\text { outcome }\end{array}$ & $\begin{array}{l}\text { Experienced } \\
\text { Interparty } \\
\text { alliance }\end{array}$ & Cosmopolitan & $\begin{array}{l}\text { Swing } \\
\text { constituency }\end{array}$ & $\begin{array}{l}\text { Party } \\
\text { stronghold }\end{array}$ & $\begin{array}{l}\text { Huge population } \\
\text { size }+60,000 \\
\text { votes }\end{array}$ & $\begin{array}{l}\text { Won by } \\
\text { Independent } \\
\text { Protester }\end{array}$ & $\begin{array}{l}\text { Sample } \\
\text { size }\end{array}$ \\
\hline $\begin{array}{l}\text { Ablekuma } \\
\text { South }\end{array}$ & Yes & No & Yes & Yes & No & Yes & No & 37 \\
\hline Bantama & $\mathrm{No}$ & $\mathrm{No}$ & Yes & No & Yes & Yes & No & 51 \\
\hline Ellembelle & Yes & Yes & Yes & Yes & No & Yes & No & 39 \\
\hline $\begin{array}{l}\text { Evalue A. } \\
\text { Gwira }\end{array}$ & Yes & Yes & No & Yes & No & No & No & 39 \\
\hline Ketu South & No & No & No & No & Yes & Yes & No & 46 \\
\hline $\begin{array}{l}\text { Klottey } \\
\text { Korle }\end{array}$ & Yes & No & Yes & Yes & No & Yes & No & 38 \\
\hline Wulensi & Yes & No & No & Yes & No & No & Yes & 46 \\
\hline Others & & & & & & & & 7 \\
\hline \multicolumn{8}{|c|}{ Total Number of Participants } & 303 \\
\hline
\end{tabular}

\footnotetext{
${ }^{1}$ Constituency with more than 60,000 registered voters is considered large because it exceeds the national average of about 56,000 registered voters and about 39,000 valid votes cast as per the 2016 electoral statistics.
} 


\section{B. Questions for Participants (a full questionnaire can be found under this section)}

Participants of the survey were mainly party elites ${ }^{2}$ (designated as members/officials of political parties). They were asked a total of 27 questions (a blend of open-ended and multiple-choice). Response from the open-ended questions were compared to those from the multiple-choice to identify the consistency of responses given by participants. Furthermore, responses from the openended questions helped to collect information from participants about their assessments on why skirt and blouse voting takes place, as well as their opinion about elite coordination successes and failures (both interparty and intraparty). The survey questionnaire is categorized into questions that collect information on the personal and district demographic profiles of participants as well as those that collect information about their party ID, their views on intraparty and interparty coordination of their political parties. A full complement of questions asked respondents are given below.

\section{Questionnaire to Party Elites (Members/Officials)}

Personal and District Demography Where do you vote (constituency name)?

1. Which of the following best describes your educational status?
A) Some primary schooling
B) Primary school completed
C) Some secondary school/high school
D) Secondary school/high school completed
E) Post-secondary qualifications, other than university
F) Some university
G) University completed and beyond
H) I don't know

2. Are you a member/official of any political party? Yes/No

3. If you answered Yes, on Question 2, which political party is that?

4. What is your position in the party?

\section{Party ID and Intraparty Coordination}

5. Please select the statement that most closely matches your view. In general, the recent parliamentary primaries of your political party were successful.

\section{A) Strongly Disagree}

\footnotetext{
${ }^{2}$ Initially, the questionnaires were titled, "Questionnaire to Party Officials". This was reworded, "Questionnaire to Party Elites (Members/Officials)" based on advice from participants on the field. I was told that the usage of party officials in Ghana is often limited to the few party-elected executives responsible for the day-to-day running of the parties. Thus, the adoption of the term "party officials" would have acted as limitation for people I had to interview. However, as I needed to interview all those involved in party affairs (MPs, nomination seekers, grassroots, cadres, etc.), I needed to change the word "official(s)" to "member(s)" in order to attract wide audience. I sought clearance from Professor Herron on the field to go ahead with the alteration.
} 
B) Moderately Disagree

C) Neutral (neither agree nor disagree)

D) Moderately Agree

E) Strongly Agree

6. Did any defeated candidate of your party threaten to leave the political party?
A) Yes
B) No
C) Don't know

If you answered Yes, on Question 6, answer questions 7 and 8, otherwise skip to question 9.

7. The party leadership was able to resolve issues of defection and has since then coordinated well.
A) Strongly Disagree
B) Moderately Disagree
C) Neutral (neither agree nor disagree)
D) Moderately Agree
E) Strongly Agree

8. How did they do it?

9. Did some losing parliamentary contestants threaten to go independent?
A) Yes
B) No
C) Don't know

10. Did some losing parliamentary contestants go independent?
A) Yes
B) No
C) Don't know

11. If Yes, was the party's leadership able to convince the disgruntled member(s) to rescind their decision?
A) Yes
B) $\mathrm{No}$
C) Don't know

12. Did any of your party executives endorse the candidature (be it presidential or parliamentary) of another party?
A) Yes
B) $\mathrm{No}$
C) Don't know 
13. Please looking at the results of the 2016 general elections do you think some members/supporters of your party voted "skirt and blouse"?
A) Yes
B) $\mathrm{No}$
C) Don't know

14. If you answered Yes, on Question 13, why do you think they voted skirt and blouse?

15. Did your presidential/parliamentary candidate plead with supporters/members or the electorates not to vote "Skirt and Blouse"?
A) Yes
B) No
C) Don't know

16. If Yes, why do you think the request was made? If No, why not?

17. Leading to the elections did your party maintain a common pool of resources for both presidential and parliamentary campaigns. Yes/No

\section{Interparty Coordination}

18. Would you recommend your party to enter into an electoral alliance in order to defeat an 'undesirable' political party"
A) Yes
B) $\mathrm{No}$
C) Don't know

19. Has your party ever entered into formal or informal electoral alliance with another party either during the main elections or presidential run-off?
D) Yes
E) No
F) Don't know

20. Why or why not?

21. Did your party endorse another candidate for either the presidential or parliamentary slot?
A) Yes
B) $\mathrm{No}$
C) Don't know

22. Why or why not? 
23. Did your party decide to leave out any constituency or withdraw a candidate from a particular constituency to help another party win that seat?
A) Yes
B) $\mathrm{No}$
C) Don't know

24. Did your party contest in both presidential and parliamentary seats in all constituencies?
A) Yes
B) No
C) Don't know

25. If No, why?

26. Have you ever voted skirt and blouse (that is to vote for presidential and parliamentary candidates in the same election from different political parties) before?
A) Yes
B) No
C) Don't know

27. Why?

\section{Participants in the study and how they were recruited}

As stated above, there were 303 participants in the study who were essentially party elites with just a few of them representing civil society, the media, and members of academia. To ensure that the research samples all the relevant political parties fairly, political parties whose parliamentary candidates pulled at least ten percent in any of the 275 constituencies in the 2016 general elections were included in the sample. In this way, five political parties were selected. They were the Convention People's Party (CPP), National Democratic Congress (NDC), New Patriotic Party (NPP), People's National Convention (PNC), and Progressive People's Party (PPP) (parties are in alphabetical order). As the political parties have unequal strengths in terms of resources and membership, it was decided to fix minimum and maximum number of samples to collect from each party as 35 and 90 . Given the specific nature of respondents required for this research and the parties involved, randomized selection was not very feasible, therefore, an attempt was made to undo any biases in the data collection. Consequently, respondents from the seven constituencies were grouped into clusters of polling stations using the Electoral Commission of Ghana's code book.

Thus, in terms of cluster, in Ablekuma South where we collected 37 samples, we surveyed eight each from Chorkor and Korle Bu but seven each from Korle Gonno, Mamprobi, and New 
Mamprobi. In Bantama, we collected 51 samples, eleven samples were taken from AbrepoMpatasie while ten each were taken from Ahenbronum, Bohyen, Kokoso-Asubonteng, and North Suntreso. In Ellembele we sampled eight respondents each from Aiyinase South, Awiebo Nyiake, Ayawora, and Kwasikrom while seven were taken from Nyame Bekyere making a total of 39. From Ketu South where we sampled 46 respondents, we administered ten surveys in Avedzi/Teshie, while surveying nine each in Flagatigorme, Gbugbla, Huime-Agordome, and Kpodzi-Agbogbome. In Korle Klottey which is part of Accra, the national capital where Ablekuma South is located and are adjoining constituencies, we collected 38 samples. Eight samples each were from Asylum Down, North Adabraka, and Odaw-Naa/Sahara while seven samples each were taken from Osu Doku and Ringway Estates. Like Korle Klottey and Ablekuma South, Evalue Ajomoro Gwira and Ellembele are contiguous constituencies as such we collected 39 samples from each of them. From Ellembele, we collected eight samples each from Aiyinase South, Awiebo Nyiake, Ayawora, and Kwasikrom while seven samples were collected from Nyame Bekyere. In Evalue Ajomoro Gwira, we collected eight each from Apataim, Brawire, Gwira Banso, and Kokoado but seven from Sikaneasem. Finally, in Wulensi where we sampled 46 respondents, we surveyed eight respondents from Chando, Gbungbaliga, Kajeso, and Lungni but seven each from Tinagyeilia and Wulensi South.

\section{Information to participants prior to conducting the interview}

Participants were briefed on the objective of the research project which was to collect data on how inter/intraparty coordination successes and/or failures affect "Skirt and Blouse" voting in Ghana. They were told that the main purpose of the research is to advance current understanding of the phenomenon of split-ticket voting in political science in general and in electoral studies in particular. They were further told that their participation in the project will involve responding to an approximately 20 to 30 minutes interview conducted by me or member(s) of my team. Their participation in the project was entirely voluntary. If a participant was unwilling or unable to participate in the project for any reason, that person could refer me or the enumerator to any other person who may be of assistance to the research efforts. They were told that if they have further questions about the study, they could contact me via skdarkwa@mix.wvu.edu, or my faculty advisor, Prof. Erik Herron via +1.304.293.9805 or by Erik.Herron@ mail.wvu.edu.

Additionally, they were told that if they are willing to participate, their involvement in the project will be kept confidential, and no reports disclosing personal identifying information will be used. The questionnaires will be treated as confidential information, stored in a secured location for the duration of the project, accessed only by myself. After analyzing the data, information obtained will be securely stored as a password protected document on an external hard drive. Participants must be 18 years of age or older to participate. They were allowed to skip any question(s) that they did not wish to answer and were told they may discontinue the interview at any time they felt like doing so. Finally, they were told that West Virginia University's Institutional Review Board's acknowledgement of the project is on file. They were also presented with the cover letter for their participation. Most of the persons contacted were very willing to participate in the research project. 
Samuel K. Darkwa

Descriptive Statistics on Demographic Profile of Participants

Table 2: Disposition of Respondents

\begin{tabular}{lrr}
\hline Description & Frequency & Percent \\
\hline Member & 25 & 8.26 \\
Chair & 24 & 7.92 \\
Secretary & 23 & 7.59 \\
Youth leadership & 25 & 8.25 \\
Campaign Coordinator & 21 & 6.93 \\
Treasurer & 12 & 3.96 \\
Director of Elections & 8 & 2.64 \\
Women Organizer & 24 & 7.92 \\
Grassroots/Cadres & 30 & 9.9 \\
Member of Parliament & 8 & 2.64 \\
Research & 12 & 3.96 \\
Results Analyst & 15 & 4.95 \\
Polling Agent & 28 & 9.24 \\
Communication team member & 30 & 9.9 \\
Civil Society & 5 & 1.65 \\
National Commission for Civic Education & 1 & 0.33 \\
Academia & 303 & 0.99 \\
Media & 9.97 \\
\hline Total & 300
\end{tabular}

Table 3: Participants' Educational Status

Description

Some primary schooling

Primary school completed

Some secondary school/high school

Secondary school/high school completed

Post-secondary qualifications, other than university

Some university

University completed and beyond

I don't know

Total

\section{Frequency Percent}

$12 \quad 4.0$

$21 \quad 6.8$

$32 \quad 10.6$

$45 \quad 14.9$

$51 \quad 16.8$

$50 \quad 16.5$

$90 \quad 29.7$

$\begin{array}{ll}2 & 0.7\end{array}$

$303 \quad 100$


Table 4: Participants' Party Affiliation

\begin{tabular}{lrr}
\hline Description & Frequency & Percent \\
\hline CPP & 41 & 13.54 \\
PNC & 38 & 12.54 \\
NDC & 87 & 28.71 \\
NPP & 86 & 28.38 \\
PPP & 44 & 14.52 \\
Not a member of any party & 7 & 2.31 \\
\hline Total & 303 & 100 \\
\hline
\end{tabular}

Table 5: Participants' Constituency

\begin{tabular}{lrr}
\hline Description & Frequency & Percent \\
\hline Ablekuma South & 37 & 12.22 \\
Bantama & 51 & 16.83 \\
Ellembele & 39 & 12.87 \\
Evalue Ajomoro Gwira & 39 & 12.87 \\
Ketu South & 46 & 15.18 \\
Klottey Korle & 38 & 12.54 \\
Wulensi & 46 & 15.18 \\
Other & 7 & 2.31 \\
\hline Total & 303 & 100 \\
\hline
\end{tabular}

\section{Membership of the research team and instructions they were given}

Membership of my research team was made up 13 persons in all. I briefed them on the goals of the research and the sampling frame. I also briefed them on the research ethics and what they were to do. They were not to influence respondents in their questions. If the respondents are not willing, they should not be forced, and the respondents were allowed to end the interview anytime during the survey. The 13-member team is made up of four field officials of the National Commission for Civic Education (NCCE) at the regions, a research person from the Ghanaian Legislative House, seven research persons from civil society and academia and me.

To ensure that the field workers do their work, I visited some of the constituencies they were working in (Ellembelle, Evalue Ajomoro Gwira, Ketu South, and Wulensi) to touch base with them. This aside, I collected the telephone numbers of some of the people they administered questionnaires to and interviewed them on the phone. These telephone interviews offered me the opportunity to obtain critical information that I would have missed. These are all discussed under telephone interviews below. These telephone interviews are different from the face-to-face 
interviews. They were meant to crosscheck what the field personnel were doing and to corroborate their reports. Though the face-to-face interview enriched the fieldwork, because most of the material collected were detailed narratives of intraparty and interparty coordination successes and failures, they were separated from the survey and were rather used to support the survey which is more quantitative in nature. Thus, the quantitative analysis in this chapter were based on the 227administered survey from the field whereas the face-to-face interviews were used to buttress the quantitative analysis. 
We WestVirginiaUniversity.

EBERLY COLLEGE OF ARTS AND SCIENCES

Re: Academic Research Project

Dear Participant,

I am Samuel Kofi Darkwa, a graduate student in Political Science at West Virginia University. I am currently conducting research on "Skirt and Blouse" voting in Ghanaian elections under the guidance of Dr. Erik Herron, professor of political science. Specifically, I am looking at how inter/intraparty coordination successes and/or failures affect "Skirt and Blouse" voting in the country. The purpose of this research is to advance current understanding of the phenomenon of split-ticket voting in political science in general and in electoral studies in particular. By this letter, you are invited to participate in this research by contributing to either elite survey, focus-group interview and/or in opened-ended interview meant for party officials administered by me.

Participation in the project will involve responding to an approximately 20 to 30 minutes interview conducted by me. Your participation in this project is entirely voluntary. If you are unwilling or unable to participate in this project for any reason, I would very much appreciate you referring me to any other person who you believe may be of assistance to these research efforts. If you wish, you can simply respond to this letter via email at skdarkwa@mix.wvuedu. If you have further questions about the study, please contact me at the above email. You can also contact my faculty advisor, Prof. Erik Herron via +1.304 .293 .9805 or by Erik.Herronamail.wvu.edu

If you are willing to participate, your involvement in this project will be kept confidential, and no reports disclosing personal identifying information will be used. The questionnaires will be treated as confidential information, stored in a secured location for the duration of the project, accessed only by myself. After analyzing the data, information obtained will be securely stored as a password protected document on an external hard drive. You must be 18 years of age or older to participate. You may skip any question that you do not wish to answer and you may discontinue the interview at any time. West Virginia University's Institutional Review Board's acknowledgement of this project is on file.

Thank you for your time and help with this project.

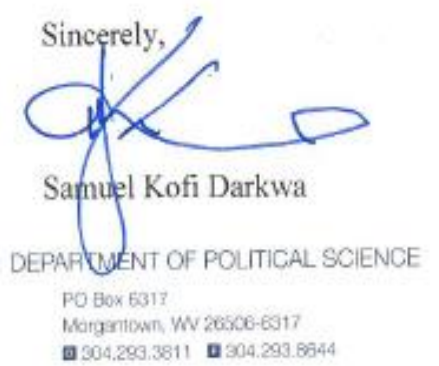

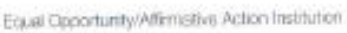




\section{CHAPTER 4. AGGREGATE LEVEL OF ANALYSIS}

\subsection{CHAPTER INTRODUCTION}

The previous chapter evaluated the micro-level foundations of split electoral outcomes, identifying features associated with individual-level decisions to split tickets in Ghana. This chapter uses constituency-level electoral data (aggregate level data) to explore how strategic coordination affects skirt and blouse outcomes (split electoral outcomes). Often, the use of an aggregate level dataset to examine ticket splitting-which is an individual level factor-is susceptible to the ecological inference fallacy ${ }^{1}$ (Burden and Kimball 2009; King 2013; King et al 2004; Roscoe 2003). However, in this case, because I employ an aggregate dataset to explain skirt and blouse outcomes, which is equally an aggregate level phenomenon, the issue of ecological inference is not a problem here. In fact, the utilization of the aggregate dataset offers a more nuanced way of examining how coordination influences splitting.

The chapter employs voter and elite coordination factors/mechanisms such as electoral volatility (Wahman 2014), effective number of parties (Cox 1997; Laakso \& Taagepera, 1979), SF-ratio (Cox 1997), deals/alliance configurations (Birch 2003), and disputed primaries in parliamentary elections (Cox 1997) to investigate the relationship between elite coordination and split outcome. Chapter 3 dealt with ticket splitting while this chapter focuses on split outcomes using aggregate data. The chapter contends that elite coordination failures and successes influence split outcomes (skirt and blouse outcomes).

The concept of split-ticket voting has been extensively researched in many political settings due to its effects on democratic representation and accountability. Some scholars have found voters who engage in this phenomenon to be sophisticated (Abramson 1983; Converse 1964; Kinder 
1983; Neuman 1986; Zaller 1992). Others have argued that centrist voters interested in moderate policies abhor extreme policies and will, therefore, vote simultaneously for two different parties so that the overall public policies formulated and implemented by the political establishments will be moderated (Alesina and Rosenthal 1989, 1995; Fiorina 1992, 1996). Finally, many of these scholars also assert that parties have different areas of expertise and that voters match parties to their respective office of competence. At the same time such voters create divided government for each arm of government to play a watchdog role over the other (Jacobson 1990; Petrocik 1991). The bottom line of these arguments is that individual voter behavior of ticket splitting at the microlevel produces certain electoral outcome at the macro or the aggregate level such as divided government. Research has found an empirical connection between split-ticket voting and split district outcomes (Burden and Kimball 2009; Campbell and Miller 1957; Rusk 1970). Again, extant literature on ticket splitting has found a statistically strong relationship between the two concepts; ticket splitting and split district outcome, both in terms of magnitude and direction (Burden and Kimball 1998, 2009; Gschwend, Johnston, and Pattie 2003; Roscoe 2003).

Since the inception of Ghana's Fourth Republican Constitution in 1992, the country has made several strides and has passed the "two-turnover-test" of democratic consolidation (Huntington 1991) and has had its third peaceful transfer of power (Graham et al. 2017 KumahAbiwu 2017). A prominent feature of Ghanaian voting behavior, which doubtlessly has contributed to this feat, is the prevalence of ticket splitting discussed in Chapter 3. Skirt and blouse voting is so popular that it has been given a local name (skirt and blouse voting for split ticketvoting and skirt and blouse outcome for split district outcome). The remarkable thing about this phenomenon is its display of nuance and complexity. 
Over the years, skirt and blouse voting in Ghana has varied substantially from election to election and from constituency to constituency and this raises several empirical questions. First, why would some constituencies produce skirt and blouse outcomes and others would not? Furthermore, why do skirt and blouse outcomes appear to be more common in some constituencies in each election and over time? What really accounts for the subnational variations in skirt and blouse voting and outcomes? Second, are skirt and blouse outcomes intended to create divided government or for crafting appropriate representation by a constituent? My dissertation argues that differences in elite coordination (successes and failures) at the constituency level are largely responsible for the subnational variations in skirt and blouse outcomes. That is, variations in elite coordination across districts and from election to election primarily account for the variations in skirt and blouse outcomes. This argument is based on Cox's (1997, 1999, 2005, 2006) coordination theory which looks at coordination at two levels: First, at the district level (interparty and intraparty) coordination and second, across districts (linkage) among legislative and presidential candidates. The chapter addresses the questions raised above using constituency-level aggregate electoral dataset which is apt as the phenomenon of interest is a split outcome which is realized at the constituency level.

Elections are interactions between voters, parties, and candidates mediated by institutional and social contexts. Elite electoral interactions (coordination) are motivated by a vital incentive of electoral success while voter coordination is to avoid wasting votes (Birch 2003; Cox 1999, 2006). These interactions and mediating factors ${ }^{2}$ such as institutional and social contexts affect the way voters cast their ballots and may in turn affect the electoral results, which may produce a split outcome (Burden and Kimball 2009; Campbell and Miller 1957; Rusk 1970). Institutional scholars 
have identified factors such as ballot type, methods of translating votes into seats, and political systems as the mechanisms responsible for split outcomes.

Some scholars have argued that ballot type affects ticket splitting and consequently split outcomes (Beck 1997; Beck et al. 1992; Campbell and Miller 1957; Rusk 1970). Per Campbell et al. (1960) the physical characteristics of an election ballot has a great influence on whether a voter will cast a straight or split vote. In their analysis, it came to light that states without a straight party option have higher probability of ticket splitting and therefore, split district outcomes. Aside from these scholars, Brace (1993) also noted that ballot type may influence voters to cast split or straight vote in an election. Other scholars such as Ames et al. (2009) and Burden and Helmke (2009) have emphasized the type of political system in place as responsible for whether voters will vote sincerely or strategically; split their ballot or vote a straight ticket. Thus, the different configurations of political and electoral systems in place in a nation affects coordination and electoral outcomes.

Generally, it has been found by scholars that pure PR systems produce multiparty competition at the district level while SMD-plurality systems tend to exercise a reductive impact on the number of candidates (Cox 1997; Ferrara, Herron, and Nishikawa 2005). This is because in SMDs, the district magnitude is " 1 ". Given this ceiling, voters, parties and candidates who want to maximize their satisfaction become strategic in their dealings. That is, voters want to influence the election while parties and candidates want to get the best return from their investment. In this way, a voter whose preferred choice is the third-ranked candidate will rather prefer to vote for one of the top two candidates than for the third-ranked candidate. Consequently, the contest in SMD is often reduced to a competition between the most viable candidates. In this way, SMDs favor two party systems. However, in PR systems because the district magnitude is greater than "1", the 
system is less punishing to small parties. Thus, a voter whose preferred choice is the third-ranked candidate will still vote for that candidate and be able to influence the system. As a result, PR systems tend to produce multiparty competition.

This situation is different in mixed-member electoral systems which employ both SMD and PR in a single election. Instead of the SMD tier exercising a reductive effect on the number of parties in the system, the interaction of the two systems often leads to multiparty competition at the SMD tier just as it is the case with the PR tier. It has been argued that the placement of candidates at the SMD tier boosts a party's votes at the PR component and this symbiotic interaction between the two tiers creates what is referred to as 'contamination effect' (Ferrara, Herron, and Nishikawa 2005; Guinjoan 2016; Herron and Nishikawa 2001). Proponents of contamination effect posit that the placement of a candidate in the SMD tier accrues vote bonus for a party at the PR component and encourages multiparty competition in the SMD tier contrary to what takes place in pure SMD systems. This is because parties improve their performance at the PR tier when they contest at the SMD tier. Due to this, parties are incentivized to contest at the SMD tier irrespective of their chances of winning seats at that tier (Ferrara, Herron, and Nishikawa 2005; Herron and Nishikawa 2001; Herron, Nemoto, and Nishikawa 2018). Thus, where more than one set of electoral rules are employed within a voting district in the same set of election, the Duvergerian rule is defeated because, multiparty competition which is a feature of the PR tier/systems spills over to the SMD tier.

Guinjoan (2016) asserts that proponents of a contamination effect hold that the overlap of electoral arenas is the main reason why parties may contest in areas they are not viable leading to non-Duvergerian equilibria. He is of the view that the overlap of electoral arenas alone is not enough to explain why parties may compete in areas they do not expect to win. To him, a party's 
decision to run or not is made by considering all the different arenas that a party contests in. These arenas are interconnected and that the decision to compete transcends each individual arena. This is because parties are not equally viable ('asymmetrically viable') in all arenas. Thus, where parties are 'asymmetrically viable,' they may run even in arenas in which they are not viable and therefore, know they will not win. He identified two factors that create asymmetric viability: incongruent electoral system and territorial or subnational variations in a party's support. Where two electoral arenas adopt the same set of rules for the elections, a party is likely to be equally viable in these arenas. However, parties become asymmetrically viable in arenas where different sets of rules are used. Furthermore, though a national party may not be equally viable in all the territories, it may take advantage of its viability in other regions to compete in areas where it is not viable. Though Guinjoan (2016) built on the contamination project, he limited his analysis to parties forgetting that elite decision to contest are influenced by what voters are doing or what they expect voters to do. In fact, voter behavior influences parties' decisions to contest and therefore, voter level factors cannot be ignored when deciding to contest. It must be stressed here that because Ghana uses the pure SMD system in a plurality first-past-the-post (FPTP), we expect Duvergerian outcomes to hold there however, elite interactions may provide some important nuances in different districts.

With respect to the political system in place, splitting in federal systems is likely to be different from those in unitary systems (Ames et al. 2009; Burden and Helmke 2009). Similarly, bicameral and unicameral legislative systems are more likely to produce different split outcomes due to the different incentives faced by elites and voters (Ames et al. 2009; Burden and Helmke 2009). Thus, the differences in politics and electoral systems present different incentives to political actors in respect to electoral coordination (Ames et al. 2009; Tavits 2008). Finally, how votes are translated into seats also affects how the electorates cast their votes and thus, influences 
the type of party system in place (Cox 1997; Duverger 1954; Riker 1962). These conditions affect how voters cast their votes and subsequently affect the composition of the electoral outcome. Thus, casting blank votes, ballot roll-off and ticket splitting are affected by the institutional and electoral system in place and these also impact the electoral outcome.

The rest of the chapter is organized as follows: Section 4.2 discusses the extant theories of ticket splitting and split outcomes such as divided government, party system volatility, effective number of parties, S-F ratio and (mis)coordination among party elites. Each of these will introduce the hypotheses that will be tested in the chapter. Section 4.3 discusses the data and measurement of the independent variables. It also addresses the dependent variable which is split constituency outcome also referred to as two-office split-result, as well as the independent and control variables. Section 4.4 then presents the model of split outcomes based on coordination problems faced by voters, candidates, and party elites. The success or failure of how these stakeholders handle the coordination problems affects ticket splitting and split outcomes. This section also presents the empirical analysis based on binary logistic regressions, which is then followed with a discussion of the implications. The chapter ends with section 4.5 which is the concluding part that provides a succinct discussion of how the coordination problem is the main determinant of ticket splitting and split outcomes.

The chapter makes a case that throughout Ghana's Fourth Republic, split outcomes have been a consistent phenomenon in its elections and this could not be attributable to the desire of Ghanaians for divided government, but rather elites' desire for certain electoral outcomes for purposes other than divided government. The justification of this position is based on two premises. First, the aggregate results show that between 1992 and 2016, seven elections have been conducted, and in all such elections, the party that won the presidency also won the majority of 
seats in parliament. Second, there were two instances in which the presidential election required runoffs, and in both instances, the rest of the contesting parties supported the candidate from the party which had won a majority of seats in parliament in the same election irrespective of whether that party was leading the presidential race (Ayee 2002; Frempong 2017; Yobo and Gyampo 2015). In both instances, the position of political elites was to protect/insulate the country's young democracy from the challenges of divided government which could potentially lead to military takeover (Ayee 2002; Darkwa ${ }^{3}$ 2019; Frempong 2017)

\subsection{THEORIES OF TICKET SPLITTING AND SPLIT CONSTITUENCY OUTCOME}

This section reviews the relevant theories of ticket splitting and split outcomes. These include divided government which suggests that voters prefer moderate policies and therefore, would split their votes between extreme polarized parties to ensure that policies produced receive necessary concessions satisfactory to the median voter. There are many nuances to the theory of divided government and they are discussed in section 4.2.1. Party system volatility is another theory that explains why voters split and why there are split outcomes. There are three strands of the concept. The first strand, which is largely Eurocentric, assumes that party entry and exit in the party system is stable and that most forms of turbulence in the party system are due to voter behavior. The second strand concerns new democracies and argues that high party volatility is largely based on elite conduct such as electoral alliances, party entry, and withdrawals from the party system. The third form attributes volatility to a blend of elite- and voter-level factors. These are explained in section 4.2.2.

The next concept that the chapter addresses is district magnitude, explained in section 4.2.3. This section argues that electoral systems and the methods of converting votes into seats are likely to create conditions favoring the effective number of electoral competitors that can contest 
elections in a given constituency. Elites are to strategically coordinate their entry to field candidates not exceeding the district magnitude plus one.

The SF-ratio (second to first loser ratio, that is, the vote share of the third-place candidate divided by the vote share of the second candidate) is discussed in section 4.2.4. The theory of strategic coordination argues that where elites field candidates more than the district magnitude plus "1" in SMD, voters will withdraw from supporting less competitive candidates and will concentrate their votes on the top two contenders. The SF-ratio is a reliable index that measures voter coordination. Another theory used to explain ticket splitting and hence, split outcome is the concept of (mis)coordination on the part of elites. This concept, discussed in section 4.2.6, considers two forms of elite coordination; largely coordination successes and failures that produce ticket splitting and therefore split outcome.

\subsubsection{Divided Government ${ }^{4}$}

The concept of divided government will largely be discussed from the US perspective because the literature on divided government in the US is well-developed and widely cited. Hence, it is appropriate to talk about the US when the concept of divided government is discussed. How the concept works in other states such as Brazil and Mexico will also be briefly discussed. In the American system, proponents of divided government argue that voters willfully divide their votes to achieve specific policy outcomes or representational arrangement moderation (Alesina and Rosenthal 1989, 1995; Fiorina 1992, 1996). In respect to policy position, the model asserts that parties hold different positions on the ideological continuum. Moderate voters who are positioned at the median segment (assuming a single dimension of salient cleavages) will be more likely to split their votes to achieve non-extreme policies. However, other scholars have shown that high party polarization gives voters distinct choices while ideological congruence blurs voter choice 
and causes ticket splitting (Petrocik and Doherty 1996; Roscoe 2003). Regarding representational arrangements, scholars who research on divided government, largely those whose work is based on the US, assert that the different political parties have their strengths and areas of competence and for that matter voters would place candidates/contestants in offices they can best handle. This is referred to as institutional matching or issue ownership or selecting 'horses for courses' (Jacobson 1990; Petrocik 1991). It has also been argued that voters intentionally vote to divide or to balance party control of the government so that the parties play a watchdog role, to prevent abuse of the public mandate (Alesina and Rosenthal 1995; Fiorina 1992, 1996; Jacobson 1990; Mebane 2000; Petrocik 1991). However, the institutional matching theorists' position that Democrats are suitable for Congress because they support social intervention policies while Republicans are best for the presidency because they manage the economy better has proven to be without merit. Thus, these claims were disproved when in the 1990s Democrats were assigned the presidency to manage the budget deficit while Republicans enjoyed a Congressional majority (Saad 1995; Roscoe 2003). There are also those who are of the view that divided government is an unintentional act, incidental, for instance, to the structural features of the American system such as separation of powers, checks and balances, as well as the practice of presidential system (Campbell 1960; Jacobson 1990).

Ames et al (2009) also argue that Brazilians for instance do not cast their votes with eventual government formation in mind. To them, the country's divided government is accidental because voters make separate decisions for presidential and deputy elections. As a result, they argued that the elections are "unlinked." It has further been argued that the sequencing of the elections, such as the mid-term elections in the United States, is responsible for divided government (Ames et al 2009; Shugart, 1995). 
Contrary to the above positions, Helmke (2009) argues that voters in new democracies do not divide government in line with the Fiorina model but rather would like to "protect themselves" by contemporaneously voting for challengers in one race and incumbents in another. This is to lessen the risks associated with voting for inexperienced and unknown challengers. The theory of divided government is one that directly connects with split outcomes irrespective of the voter intentions or reasons assigned it. This relates to the concept of two-office split-result (Burnham 1965; Cummings 1966; Feigert 1979) where one party wins the executive and the other has legislative majority at the national level. Divided government is expected to have a direct relationship with split outcome (Burden and Kimball 1998; Gschwend, Johnston, and Pattie 2003). At the individual level too, divided voting (ticket splitting) could be linked directly to divided outcomes (Burden and Kimball 1998, 2009).

\subsubsection{High Party Volatility}

The concept of electoral volatility explains how voters are willing to switch between parties from election to election. It shows that voters do not have strong party attachment with stable and consistent voting behavior from election to election (Evans 2002; Pedersen 1979; Rose \& Urwin 1970; Taagepera \& Grofman 2003). Electoral volatility also shows that voters are free to choose who to vote for in an election based on the issues of the day or candidates involved (Birch 2003; Tavits 2008). Given that voters do not have strong party attachment with stable and consistent voting behavior from election to election and the fact that voters are free to choose who to vote for in an election based on the issues of the day or candidates involved, we can have a link between volatility and ticket splitting. Volatility refers to the net change in the party system due to changes of voter preferences over time. To measure volatility, I will sum up the change in each party's vote share in the current and previous election, then add up the absolute values of the changes in vote 
shares (for all parties) and then divide the sum of the absolute values by two. Conventionally, when volatility or turbulence in the party system is mentioned in established democracies, it is assumed that party supply (party entry and exit) is largely in a state of equilibrium and that all changes are mainly due to voter activities such as switches in partisan affiliations, abstentions, among others. As a result, Pedersen (1979) defines volatility as "the net change within the electoral party system resulting from individual vote transfers" (Pedersen 1979, 3). It is worth stressing that most of the studies on volatility which are largely based on the established democracies did not distinguish between the role of electorates and elites when considering party-system changes.

Meanwhile, studies from emerging democracies have found that volatility in new democracies is largely elite-driven (Gunther 1989; Mair 1997; Van Biezen 2003). These scholars assert that elite strategizing is substantively responsible for the erratic electoral outcomes from election to election and therefore better explains volatility in nascent party systems (Gunther 1989; Mair 1997; Toole 2000). Like their counterparts whose work is focused on advanced democracies, these scholars are also at the other extreme by explaining volatility solely from an elite perspective and ignoring the role of the voters. To borrow the terms of Roscoe (2003), voters are like diners at a restaurant whose choices are limited by the available menu. Thus, scholars who have studied the subject in advanced and emerging democracies are similar in opposite ways as they view the phenomenon exclusively from voter and elite perspective respectively.

Finally, there are other scholars who view party system stabilization as the combined effect of elite and voter actions (Cox 1997; Kitschelt et al. 1999; Rose \& Munro 2003). These studies are based on electoral politics where strategic coordination of elites and the electorates are critical. Voters who want to avoid wasting their votes on nonviable contestants prefer to coordinate on the 
few viable ones for their votes to count. Likewise, when elites are planning their withdrawal, entry and alliance strategies, they consider both voter expectations and the electoral rules in place.

These considerations aside, two scholars who have made significant contributions to research on volatility are Birch (2003) and Tavits (2008). To Birch, the overall volatility between successive elections is determined by the interactive effects of three factors. The first factor is the change in party support of individual voters who vote at both past and current elections. The second factor is the change in the configuration of the electorates due to exits, entries, and variations in abstention. Third, factors such as non-contestation, changes in the range of parties on offer due to party entries, exits, and alterations in the composition of coalitions affect volatility in many ways. These are voter and elite level factors responsible for volatility. Birch, thus, distinguishes between volatility, which is largely voter action, and party replacement which is purely the acts of elites as responsible for party system stabilization. Birch further argues that the former works best in advanced democracies while the latter is suitable for new democracies.

Building on that concept, Tavits (2008) distinguishes the roles of elites and voters in the determination of party system stabilization in new democracies. She found that electoral volatility (party system - changes and stability) is highly elite driven and shaped by factors such as high candidate and party attrition rate and high rate of alliance fluidity in Central and Eastern Europe. Voters' role is largely influenced by the available choice set especially parties and candidates running. Such elite acts are motivated by certain incentives that encourage or discourage system stability. This finding is supported by work on Africa where the main challengers in these democracies often change between elections (Kuenzi and Lambright 2001; Lindberg 2007; Wahman 2014). It is further supported by some scholars who found instances where strong candidates either switched parties or ran as independent candidates when they fail to secure party 
nomination they contested (Lindberg 2007; Randall and Svasand 2002; Wahman 2014). Based on these findings, this dissertation adopts Pedersen's (1979) conceptualization of volatility to measure voter-level effects (voter coordination) of party system change since there are several elite-level factors (elite coordination) such as disputed primaries in parliamentary elections and deals between parties and candidates. I expect high party volatility to produce split outcome if the net change in voter preferences over time in the different races lead to the election of candidates from different parties in the same constituency. Thus, the first hypothesis is that:

H1: the higher the level of volatility in a constituency, the higher the likelihood of split outcome.

It is expected that high volatility will directly correlate with split outcome and thus, have a positive relationship with split outcome. This means that as the level of volatility increases, split outcome increases and as volatility level declines, split outcome is expected to fall.

\subsubsection{Effective Number of Parties (ENP)}

Duverger (1954) posits that "The simple-majority single ballot system favors the two-party system" (Duverger 1954, 217) while the "simple majority system with second ballot and proportional representation favors multipartism" (Duverger 1954, 239). Simplifying these propositions, Cox $(1997,1999)$ argues that every electoral system prescribes a "ceiling" for the effective number of candidates that can contest the elections. This is given by the $M+1$ rule; where $M$ represents the district magnitude (number of seats in a given district). Since parties and candidates can field contestants to exceed the $M+1$ rule, and given that parties differ in relative strength, Laakso \& Taagepera (1979) have developed effective number of parties (ENP) index to measure how votes are distributed among the competitors. The ENP calculates the relative strength of parties based on their vote or seat share ${ }^{4}$. Though the ENP is not interested in the count of parties, it relies on the number of parties and their vote/seat share to generate their relative strength. 
The ENP should be close to 1 where there is one party dominance (where one party receives a landslide victory), and close to the number of parties contesting the election when each party receives an equal vote share. The more the ENP exceeds the $M+1$ rule, the higher the probability of a split outcome where the candidates that voters prefer in the different races are not from the same party.

As I noted in a previous chapter, Cox $(1997,1999)$ distinguishes two $M+1$ rules. In its first usage, the $M+1$ rule relates to the entry rule that the district magnitude prescribes to political elites and candidates. This rule suggests that the viable number of candidates in, for instance, a single member district (SMD) is two $(M+1$ candidates). Thus, the first $M+1$ rule relates to strategic entry. As there are fewer seats than potential candidates, and given the entry rule, party elites are required to coordinate in order not to exceed the district magnitude in terms of the required number of candidates.

In its second usage, the $M+1$ rule relates to strategic voting after parties and candidates have entered the elections. It shows that the contest in SMD is likely to reduce to a two-candidate affair. In some contexts, there could be more than two effective candidates in a single member district, but over time in FPTP the $M+1$ rule has a reductive effect on candidate entry because of the tendency for voters to focus on the more competitive candidates (voter coordination) by defecting from the less competitive ones. Generally, there are only two effective or viable candidates in SMDs with a plurality rule even where there are multiple candidates contesting in that constituency, voters tend to concentrate on the top two candidates. Thus, the second $M+1$ rule relates to strategic voting. As voters will like their votes to count, they will like to be strategic in their voting if party elites and candidates fail to coordinate on $M+1$ candidates. The caveat is that not all voters are strategic because there are party core voters who will vote sincerely for their 
parties irrespective of the chances of their parties' candidates. Thus, the presence of sincere voters and elite coordination problems explain how ticket splitting takes place where there is higher party fragmentation. Hence, the second hypothesis is that,

H2: the higher the level of party fragmentation in a district, the higher the likelihood of split outcome if candidates that voters prefer in the different races are not from the same party.

This implies that the further the district magnitude is exceeded by contestants in a constituency (which is a sign of elite coordination failure), the higher the possibility of split outcome if the candidates that voters prefer in the different races are not from the same party. My focus here is to determine whether elite coordination is successful which is determined by the first $M+1$ rule. It is only when elites fail in their coordination that the second $M+1$ (voter coordination) becomes inevitable. Meaning where party elites and candidates have failed to coordinate on $M+1$ candidates, given the presence of at least some sincere voters, then I expect the result of sincere and strategic voting to likely lead to ticket splitting and consequently to split outcome. That is, where the candidates elected in the different races are not from the same party. Here, the expected relationship between exceeding the district magnitude and split outcome is positive in respect of magnitude and direction. It worth pointing out however, that as an exception, an SMD race with a majority runoff rule, is not likely to have party competition to be reduced to a two-party affair (Cox 1997; Duverger 1954). In such a system, the district magnitude could be one (M=1), but the effective number of parties is not reduced to two in the first round (Cox 1997; Duverger 1954).

\subsubsection{SF-Ratio in Single Member Plurality System}

Flowing from the above, where the first $M+1$ rule is breached, the second $M+1$ is expected to follow where voters will now do their coordination by defecting from the less viable candidates or concentrating their votes on the two top contenders as in the above example of a single member 
district. To determine this, we are to find the vote difference between the second and third placed contestants. Cox (1997) provides us with an appropriate measure, referred to as the SF-ratio, which represents the vote ratio between the second and first losers (that is the ratio between the secondand third-placed contestants) in a single member plurality FTPT constituency. The SF-ratio provides a useful guide of voter coordination indicating defection from non-competitive to more competitive contestants (Moser and Scheiner 2009; Wahman 2014). Cox (1997) argues that where voters have information on the viable candidates in single member plurality constituencies, the SF-ratio will be close to zero, but where voters are uninformed or do not want to cast strategic votes, the SF-ratio will be close to one. Thus, the SF-ratio is between zero and one whether voters vote sincerely or strategically. Employing Cox's SF-ratio to investigate ticket splitting in mixed member systems in a ten-country case comprising 35 elections, Moser and Scheiner (2009) found that in established democracies splitting was more of a strategic act whereas personal voting drives splitting in new democracies. The most important finding of Moser and Scheiner (2009) is that in both established and new democracies, the SF-ratio provides an indication of voter defection from unviable competitors, and this could be computed from the district aggregate electoral dataset.

Though the SF-ratio has been used by many scholars to measure voter coordination by assessing voter defection from unviable contestants, it has been criticized of its inability to account for instances where a high number of parties other than the second and third placed ones receive small share of votes that become substantial when added together (Singer \& Stephenson 2009). The SF-ratio has also been criticized by Gaines (1999) for wrongly indicating non-Duvergerian equilibrium in instances where there is a tie between the second and third placed contestants. These criticisms notwithstanding, the SF-ratio remains a useful measure of computing voter coordination from aggregate data, especially when it comes to investigating voter defection from less 
competitive parties/candidates. In single member districts (SMDs), an SF-ratio of one or close to it is an indication that elites did not coordinate on only two competitors prior to the election or the presence of more sincere voting, while SF-ratio of zero is an indication of thorough elite coordination on only two candidates and that there was no second loser. Where the SF-ratio is close to zero, we have a Duvergerian equilibrium which asserts that SMD system leads to two party system at the district/constituency (Duverger 1954). SF-ratio close to zero also means that there is less sincere voting going on. Where there is less sincere voting going on, all things being equal, the effect of sincere voting on the overall election will be infinitesimally small but enough to keep third-rank parties contesting elections. This means that winning an election in either legislative or presidential race is largely a function of strategic voters who are also more likely to withdraw from trailing candidates. Thus, where elites fail to coordinate on viable candidates, there will be higher likelihood of defection from less competitive candidates. This will cause split outcome if the viable candidates in the different races are not from the same party. Hence, the third hypothesis is that:

H3: the more elites fail to coordinate on viable candidates, the higher the likelihood of voter defection from less competitive candidates and the higher the likelihood of a split outcome if the viable candidates in the different races are from different parties and there is a presence of sincere voters.

I will rely on the legislative race to generate my SF-ratio since in most cases, voters vote sincerely at the presidential race and strategically at the legislative races. This is because, all parties normally can have candidates of comparable quality at the presidential race than in the legislative race. As such, the SF-ratio at the parliamentary race is more likely to measure voter defection from less competitive candidates than in the presidential race. This also shows how voter coordination 
Samuel K. Darkwa

can explain ticket splitting especially where candidates that voters select are from same party (decrease splitting) or different parties (increase splitting).

\subsection{5 (Mis)coordination}

The preceding discussion brings us to the issue of strategic coordination adopted by party elites in their interactions. Cox's main argument about strategic coordination is that, because there are fewer seats than potential candidates, party elites are to coordinate their entries based on the first $M+1$ rule discussed above under 4.2.3 District Magnitude. Cox specifically gave a classic example of elite coordination where he stated that if there are about 15 viable competitors from, say, Social Democratic Parties who are willing to enter the election, elites are required to coordinate the actions of many people for that political party to make any significant impact in the election (Cox 1999, 146). To Cox, elites are expected to do one important thing which is to limit the number of viable candidates willing to enter the electoral fray from a given political party or political ideology. A generally accepted method of limiting the number of contestants is the nomination process. He was quick to caution that if the nomination process were not transparent and democratic it would pose problems. Again, party elites are required to persuade disappointed nomination seekers from contesting the election as independent candidates so that the party's votes are not divided. This means that elites may fail in their coordination when they do not limit nomination but allow all viable candidates to enter the electoral fray or do not manage a transparent and credible nomination. Where the nomination process ends up with aggrieved nomination seekers defecting, then it is a clear evidence of elite failure.

Consequently, the coordination role expected of party elites regarding contestants' entry is two-pronged. First, they (party elites) are to harmonize the entry of all the viable nomination seekers with the view of limiting the number of contestants. Where elites fail in this task, it is 
expected that there will be unrestricted entry (free-for-all entry) which is likely to adversely affect the electoral fortunes of that party or ideological block. This is what Cox (1999), and Navia \& Saldaña (2015) found to cause the defeat of the Concertación Alliance (Concertación Party) of Chile. That was also the plight of most Japanese parties that Cox studied. Second, in limiting the number of contestants, elites are to ensure that the nomination process is democratic, transparent, generally accepted, and not viewed as done to favor a particular contestant. Anything short of this is likely to trigger dissent especially from contestants who experience unfavorable terms. Thus, it is likely to expect high rates of disagreements (disputes) from aggrieved nominees where the nomination process is seen to be undemocratic. Undemocratic nomination is what has bedeviled many emerging democracies including Africa leading to high rates of disputed primaries in these settings (Kuenzi \& Lambright, 2001; Lindberg, 2007; Wahman, 2014).

These scholars have found that, disputed/unfair nomination in African democracies has produced two effects. The first is a high rate of candidate replacement by parties. The second is high rate of independents. That is, instances where strong candidates fail to secure the party nomination they contest, such contestants either switch parties or run as independent candidates (Pettai and Kreuzer 2001; Resnick, 2013; Wahman, 2014). In Ghana for instance, it has been found that lack of internal democracy in some of the political parties, (especially the dominant ones), account for disputed primaries in parliamentary elections leading to aggrieved primary contestants at the constituencies contesting the elections as independent candidates causing ticket splitting (Bob-Milliar 2012; Bob-Milliar \& Bob-Milliar 2010; Debrah 2014; Smith 2002a). In a similar vein, some scholars attribute Brazilian ticket splitting and for that matter its split outcome as a sign of "extreme party underdevelopment" (Ames et al 2009; Mainwaring and Scully 1995; Power 
2000). Therefore, I expect elite failure in the nomination process especially with regards to disputed primaries in parliamentary elections to cause ticket splitting, consequently:

$\mathrm{H} 4:$ the higher the level of disputed primaries in parliamentary elections due to unfair nomination procedure, the higher the likelihood of ticket splitting and hence split outcome.

Disputed primaries in parliamentary elections are expected to be positively related to ticket splitting and split outcome, all things being equal. This means that, as elite miscoordination in the form of disputed primaries in parliamentary elections increases, ticket splitting and for that matter, split outcome is expected to increase all things being equal. It is significant to note that even in the midst of elite coordination problems some voters will still vote (sincerely) for their nonviable candidates/parties.

Party elites do not only experience coordination failures (disputed primaries), they also experience significant coordination successes, and these keep their parties alive. In fact, many comparative scholars such as Benoit (2001), Birch (2003), Golder (2006), and Tavits (2008) have found party elites to engage in alliances and changes in the configurations of alliances that have shaped voter choices in certain directions during elections. Birch (2003) for instance, observed that in countries where the president is directly elected, the presidency is more valued than the legislature, and that politicians negotiate all sorts of deals for electoral purposes. Such different configurations of deals made by politicians affect the available choice set and therefore, impact the way voters cast their ballots. In Ghana for instance, when one of the two major parties enter alliance with the smaller parties, often, the smaller parties defer the presidential slot to the bigger party in exchange for support in the parliamentary race (Agyeman-Duah 2005; Boafo-Arthur 2006; Darkwa 2019; Frempong 2017). In this vein, the bigger party also defers the legislative races in some constituencies to the smaller party. It was by such deals that some of the minor parties such 
Samuel K. Darkwa

as the NCP, PCP, CPP and EGLE have had seats in parliament between 1993 and 2016 (Darkwa 2019; Frempong 2017). Hence, this study expects a positive link between electoral deals and ticket splitting. Thus,

H5: the more elites negotiate deals in which one party trades its presidential contest and supports the other for a corresponding assistance in the parliamentary race, the higher the likelihood of ticket splitting and hence split outcome.

Thus, the negotiated deals among elites involving trading off parliamentary race by one party for support in presidential contest from the other party are likely to produce ticket splitting with a likely split outcome. In emerging democracies, because political institutions are less developed and personal votes count a lot (Birch 2003; Moser \& Scheiner 2009; Tavits 2008), political elites are very flexible in entering new deals and altering existing ones all with the view of improving their electoral objectives. Thus, alliances are very fluid in emerging democracies and these in turn affect their electoral outcomes in a way different from their developed counterparts. It worth stressing that often the varying configuration of alliances in new democracies produce ticket splitting and to some extent, split outcomes.

\subsection{DATA AND MEASUREMENT}

The data for this chapter comes from multiple sources. The first and the main dataset is taken from the Election Passport ${ }^{5}$ which provides constituency-level electoral data for six Ghanaian general elections (1996 to 2016). This dataset is reliable and has been used by many scholars and research organizations in electoral studies. However, as it is the case of many datasets, the Electoral Passport dataset has missing data for 2008 and 2012 presidential races at the constituency level. The missing dataset is supplemented with data from the Electoral Commission 
of Ghana, the institution responsible for elections. Thus, the aggregate electoral data for this project is complete and reliable. The second dataset is the Ghana Living Standards Survey (GLSS) compiled by the Ghana Statistical Service. Four of these reports published between 1995 and 2014 are used to determine the ethnic profile for each constituency for the period under review. These reports are the GLSS3 published in March 1995, GLSS4 published in October 2000, GLSS5 published in September 2008 and the GLSS6 published in August 2014. Third, the dissertation uses published works and media reports that have recorded constituencies with disputed party primaries where disappointed primary seekers have entered the election as independents because disagreements relating to these primaries were not resolved. The reports also published deals entered by political parties for electoral purposes. These materials played very critical role in identifying constituencies with disputed primaries in parliamentary elections and deals among elites ${ }^{6}$.

\subsubsection{Dependent variable}

The main dependent variable is skirt and blouse outcome (split constituency outcome) that is whether a constituency had a split outcome or not. I generated a variable for skirt and blouse outcomes for the period 1996 to 2016 by comparing the parliamentary and presidential results of each constituency. Skirt and blouse constituencies are coded as “1”, otherwise coded as "0”. As the dependent variable is dichotomous (a constituency split or not), the dissertation uses binary logistic regression, and the level of analysis is the constituency. Details of the coding for both dependent and independent variables are provided in Appendix 4.2 below. 


\subsubsection{Independent Variables}

To evaluate the five hypotheses presented above, the dissertation provides five main independent variables which are disputed primaries in parliamentary elections, deals, district magnitude (effective number of parties), volatility, and second to first loser ratio (SF-ratio) for parliamentary elections where elite and voter coordination are prevalent.

Disputed Primaries in Parliamentary Elections: In Ghana, disputed primaries in parliamentary elections (a major elite coordination problem) occur mainly due to lack of internal party democracy in the nomination process. There are published works and media reports that have recorded constituencies with disputed party primaries $^{6}$. Since disputed primaries in parliamentary elections are likely to cause split outcomes, every constituency with at least one disputed primary is coded as " 1 " otherwise coded as " 0 ". It would have been preferable to distinguish constituencies based on where just one party had a disputed primary and where more than one party had disputed primaries in parliamentary elections so that I could use the percentage of disputed primaries in parliamentary elections in each constituency instead of the dichotomous variable. However, given that there are 275 constituencies in Ghana and I could not follow the parties' primaries in person, I only depended on available data from published works and newspaper publications; those I could lay hands on do not provide this nuanced information. As a result, there could be false negatives, especially instances where I may incorrectly indicate the absence of disputed primary in some constituencies. Table 4.1 below provides a summary of disputed primaries for each electoral period between 1996 and 2016. The column for prior period records instances where a constituency that had had a disputed primary in the immediate past election has a recurrent experience in the current election period. The column for previous experience, on the other hand, considers instances where 
a constituency witnessing disputed primary now, had had a similar experience in any of the past elections except the immediate past one.

Table 4.1: Descriptive Statistics of Parliamentary Disputed Primaries (1996-2016)

\begin{tabular}{rrrrrr}
\hline Year & Observation & $\begin{array}{c}\text { Disputed } \\
\text { Primaries }\end{array}$ & $\begin{array}{c}\text { Undisputed } \\
\text { Primaries }\end{array}$ & Prior Period & $\begin{array}{c}\text { Previous } \\
\text { Experience }\end{array}$ \\
\hline 1996 & 200 & 20 & 180 & N/A & N/A \\
2000 & 200 & 12 & 188 & 2 & 2 \\
2004 & 230 & 19 & 211 & 0 & 3 \\
2008 & 230 & 19 & 211 & 6 & 3 \\
2012 & 275 & 26 & 249 & 3 & 6 \\
2016 & 275 & 37 & 238 & 3 & 12 \\
\hline
\end{tabular}

Author's compilation from published books and media reports ${ }^{6}$

Effective number of parties (ENP): I generated the ENP from legislative elections results by first computing the vote share of the competing parties/candidates in a given constituency. Second, I squared each contestant's vote share and summed up the values. Finally, I computed the reciprocal of sum of squares. This is summarized by the formula, ENP $\left.=1 / \mathrm{sum}^{\mathrm{p}} \mathrm{pi}^{\wedge} 2\right]$ where $p i$ is the share of votes/seats of the ith party (Cox 1997; Laakso and Taagepera 1979) ${ }^{7}$

Volatility: I computed electoral volatility from legislative electoral results for each constituency using the Pedersen index which measures the aggregate change in vote share in that constituency. I modified the Pedersen Index to have my values ranging from " 0 "- 1 " rather than from " 0 "- " $100 "$. To do this, I first computed the change in each party's vote share at time $t$ and time $t-1$ (current and previous election). Second, I summed up the absolute values of the changes in vote shares. Finally, I divided the sum of the absolute values by two. This index ranges between 0 and 1. In general, values close to one indicate high party volatility, while values close to zero indicate low levels of volatility. 
Samuel K. Darkwa

SF-Ratio: I generated the SF-ratio using the vote ratio between the third-place and secondplace candidates from the legislative results in a given constituency. Where there is no third-place candidate, the SF-ratio is zero and where the vote difference between the third-place and secondplace candidates is small, the SF-ratio approaches one. Generally, higher SF-ratio (close to one) is a signal of less voter coordination, while low SF-ratio implies effective party elite coordination.

Deal: Deal is a coordination tool employed by Ghanaian political actors. It happens where a party enters formal or informal electoral coalition (electoral arrangement) with either another party or with a candidate of another party. Deal is measured as a dichotomous variable where constituencies with deals are coded as " 1 ", otherwise coded as " 0 ". In such deals, the minor party often defers its presidential slot and supports the major party's presidential candidate in exchange for support from the latter in the legislative race in selected constituencies that the latter defers to the minor party.

\subsubsection{Control Variables}

To address alternative explanation at the constituency level of analysis, this dissertation controls for regional effects, distance and Ethnic fractionalization.

Regional Effect: I control for regional effect, as contiguous constituencies are more likely to vote in identical ways. The regional effect assigns each constituency in a region the same value, based on the percentage of constituencies in that region in relation to the skirt and blouse outcome in that region in the previous election. To measure this, I computed the proportion of skirt and blouse outcome at time $t-1$ for each constituency within each region. The justification is that some regions (geographical areas) of Ghana are considered swing regions in the sense that they often 
change their voting pattern. These regions are notorious for skirt and blouse voting (Frempong 2017; Lindberg 2013; Weghorst \& Lindberg 2013).

Distance: To control for how legislators' closeness to their constituents from the national capital where they converge to make laws may affect skirt and blouse, I use the distance from the constituency capital (or the most prominent city in each constituency) to the national legislative house as a measure. The assumption is that legislators closer to the national capital may be able to interact more with constituents and thus affect skirt and blouse more than those far away.

Ethnic fractionalization: I computed ethnic fractionalization using the HerfindahlHirschman Index (HHI) by squaring each ethnic group's population share in that constituency and then found the sum of those numbers. To obtain the proportion of each ethnic group's population share, I used the ethnic profile of each constituency as per the appropriate GLSS report. For instance, I used the GLSS 3 published in March 1995 when computing the 1996 ethnic fractionalization and the GLSS 4 published in October 2000 for the 2000 ethnic fractionalization figures. The GLSS report is given at the regional level. To generate the constituency equivalence, I used the proportion between the presidential valid votes cast at the regional and constituency levels.

\subsection{Estimation Strategy for Skirt and Blouse Outcome under Coordination Theory}

This chapter of the dissertation is interested in how coordination successes and/or failures impact ticket splitting, and hence, split outcomes. Elite coordination success is expected to lessen skirt and blouse voting and therefore reduce skirt and blouse outcomes. Where elites fail to coordinate, or their coordination ends in failure, voters are likely to coordinate on the most viable candidates. Where any of these or their combination occur, I expect skirt and blouse voting to 
Samuel K. Darkwa

increase, resulting in skirt and blouse outcomes if there are no mutual crossovers. Thus, elite coordination success is expected to diminish skirt and blouse outcomes. Since the interest of this chapter is skirt and blouse outcomes, it employs logit regression because the dependent variable is binary. Three models were assessed for each of the six elections considered here using the same aggregate electoral datasets. The first model regressed the dependent variable on only the control variables. The second regressed the dependent variable on only the independent variables. Finally, the dependent variable was regressed on all the independent and control variables. These were done to determine how the different models affect split outcome.

\subsubsection{Results}

The results for the three models are shown in Tables 4.2 to 4.5 below. Consistent with the theoretical expectations of the dissertation, most of the elite level coordination coefficients were significant and were in the expected direction as per the regression models in Table 4.5 and the changes in probabilities in Table 4.6. Generally, the independent variables were meaningfully significant, and the results confirmed most of the research hypotheses. As indicated by Table 4.2 below, where the dependent variable was regressed on only the control variables the results present interesting findings. The results found no support for regional effect which suggests that contiguous constituencies are influenced by the voting behavior of the adjoining ones. Distance, which purports that skirt and blouse is likely in instances where a legislator's constituency is far from the National Assembly, was supported by the model. 
Samuel K. Darkwa

Table 4.2: Logit Analysis of Skirt \& Blouse Outcome Using Aggregate Electoral Data (Control Variables Only)

VARIABLES $\quad$ Estimate/SE

Regional Effect

Distance

$0.0022 * * *$

$(0.0004)$

Ethnic fractionalization $-0.0002 * * *$

Constant $-2.4203 * * *$

$(0.2729)$

Observations 1,410

Log likelihood $-413.78$ McFadden's R ${ }^{2}$ 0.036

Standard errors in parentheses $* * * \mathrm{p}<0.01, * * \mathrm{p}<0.05, * \mathrm{p}<0.1$

Finally, ethnic fractionalization was significant with a negative coefficient, meaning ethnic fractionalization and split outcome (skirt and blouse outcome) are negatively related. That is, as ethnic fractionalization increases, skirt and blouse outcome reduce, and vice-versa. When the dependent variable was regressed on only the independent variables as shown in Table 4.3, the dissertation found support for hypotheses two, four, and five which are all elite level coordinationbased hypotheses. The second hypothesis which predicted that when the district magnitude is exceeded because elites did not coordinate their entry or failed in their coordination, there will likely be a split-ticket voting leading to a possible split outcome was supported by the dissertation. Again, hypothesis four predicted that ticket splitting and consequently, split outcome will surge as parliamentary disputed primaries increase and vice versa was also supported by the model. The fifth hypothesis; electoral deals entered into by elites was also supported by the model. Thus, H5 which predicted that deals between political actors that require trading off one race for a support 
Samuel K. Darkwa

in another race to produce split outcome was confirmed by the model. However, hypotheses one (volatility) and three (SF-ratio) were not supported by the model as shown in Table 4.3 below.

Table 4.3: Logit Analysis of Skirt \& Blouse Outcome Using Aggregate Data (Independent Variables Only)

\begin{tabular}{ll}
\hline VARIABLES & Estimate/SE \\
\hline Disputed Primaries in Parliamentary Elections & $2.3874 * * *$ \\
Volatility & $(0.2404)$ \\
Effective number of parties & -0.0964 \\
& $(0.3770)$ \\
SF-Ratio & $3.1381^{* * *}$ \\
& $(0.3786)$ \\
Deals & -0.3837 \\
Constant & $(0.5797)$ \\
& $1.5969 * * *$ \\
\hline Observations & $(0.3389)$ \\
Log likelihood & $-9.0956 * *$ \\
McFadden's $\mathrm{R}^{2}$ & $(0.7884)$ \\
\hline
\end{tabular}

Standard errors in parentheses $* * * \mathrm{p}<0.01, * * \mathrm{p}<0.05, * \mathrm{p}<0.1$

To ensure that the results were consistent, I regressed the dependent variable on all the variables; both independent and control variables. The results given in Table 4.4 below are not much different from those in Tables 4.2 and 4.3 above. Again, hypotheses two (effective number of parties), four (disputed primaries at the parliamentary elections), and five (deals) were confirmed by the model with the signs in the expected direction as before. Again, hypotheses one (volatility) and three (SF-ratio) were still not supported by the model in Table 4.4 as in Table 4.3 when only the independent variables were used in the regression. It worth pointing out, however, that when all the variables were combined in a single model, it was only ethnic fractionalization hypothesis which was significant among the control variables. 
Samuel K. Darkwa

Table 4.4: Logit Analysis of Skirt \& Blouse Outcome Using Aggregate Electoral Data (All Variables)

\begin{tabular}{ll}
\hline VARIABLES & Estimate/SE \\
\hline Disputed Primaries in Parliamentary Elections & $2.4028^{* * *}$ \\
Volatility & $(0.2437)$ \\
Effective number of parties & -0.2081 \\
& $(0.4530)$ \\
SF-Ratio & $3.1758^{* * *}$ \\
& $(0.4238)$ \\
Deals & -0.2234 \\
Regional Effect & $(0.5914)$ \\
& $1.5563 * * *$ \\
Distance & $(0.3472)$ \\
Ethnic fractionalization & 1.2274 \\
Constant & $(0.9533)$ \\
& 0.0005 \\
Observations & $(0.0005)$ \\
McFadden's ${ }^{2}$ & $-0.0002 * *$ \\
\hline Standarelihood & $(0.0001)$ \\
& $-8.7825 * * *$
\end{tabular}

Standard errors in parentheses $* * * \mathrm{p}<0.01, * * \mathrm{p}<0.05, * \mathrm{p}<0.1$

Table 4.5 presents a model that includes year dummies with all the variables used in Table 4.4 above and the results were consistent with those discussed above. Hypotheses two (effective number of parties), four (disputed primaries in presidential primaries), and five (electoral deals) were all significant as before. Again, among the control variables, it was only ethnic fractionalization hypothesis that was significant. In terms of the measure of fit for the models, it is significant to note that the model in Table 4.6 with McFadden's $\mathrm{R}^{2}$ of 0.252 which is the model 
Samuel K. Darkwa

Table 4.5: Logit Analysis of Skirt \& Blouse Outcome Using Aggregate Electoral Data 1996-2016 (With Year Dummies)

\begin{tabular}{|c|c|}
\hline VARIABLES & Estimate/SE \\
\hline Disputed Primaries in Parliamentary Elections & $\begin{array}{l}2.3913 * * * \\
(0.2468)\end{array}$ \\
\hline Volatility & $\begin{array}{l}-0.0918 \\
(0.7439)\end{array}$ \\
\hline Effective number of parties & $\begin{array}{l}3.4483 * * * \\
(0.4577)\end{array}$ \\
\hline SF-Ratio & $\begin{array}{l}-0.1112 \\
(0.6089)\end{array}$ \\
\hline Deals & $\begin{array}{l}1.5293 * * * \\
(0.3593)\end{array}$ \\
\hline Regional Effect & $\begin{array}{l}1.2066 \\
(1.0032)\end{array}$ \\
\hline Distance & $\begin{array}{l}0.0003 \\
(0.0006)\end{array}$ \\
\hline Ethnicity & $\begin{array}{l}-0.0002 * \\
(0.0001)\end{array}$ \\
\hline 1996 Election & $\begin{array}{l}-0.4698 \\
(0.6952)\end{array}$ \\
\hline 2000 Election & $\begin{array}{l}-0.8891 * * \\
(0.4037)\end{array}$ \\
\hline 2004 Election & $\begin{array}{l}-0.3790 \\
(0.3718)\end{array}$ \\
\hline 2008 Election & $\begin{array}{l}-0.4548 \\
(0.3558)\end{array}$ \\
\hline 2016 Election & $\begin{array}{l}-0.3023 \\
(0.3296)\end{array}$ \\
\hline Constant & $\begin{array}{l}-9.0095^{* * *} \\
(0.9057)\end{array}$ \\
\hline Observations & 1,410 \\
\hline Log likelihood & -321.10 \\
\hline McFadden's $\mathrm{R}^{2}$ & 0.252 \\
\hline
\end{tabular}

Standard errors in parentheses $* * * \mathrm{p}<0.01, * * \mathrm{p}<0.05, * \mathrm{p}<0.1$

that includes year dummies is comparatively better than that of Table 4.3 with McFadden's $\mathrm{R}^{2}$ of 0.036 which was ran with only the control variables. Again, since all the models with the exception 
of that which was ran with only the control variables, lie within the conservative 0.2 and 0.4 range of McFadden's $\mathrm{R}^{2}$, it can be said that the model does well in modeling the relationship between the independent variables and split outcome (McFadden 1974, 1977).

Table 4.6: Effect of Changing Variables from Their Minimum to Maximum Values on Probability of Ticket Splitting

\begin{tabular}{lc}
\hline Variables & Change in Probability of \\
& Splitting \\
\hline Disputed Primaries in Parliamentary Elections & 0.300 \\
Volatility & -0.008 \\
Effective number of parties & 0.721 \\
SF-Ratio & -0.025 \\
Deals & 0.139 \\
Regional Effect & 0.062 \\
Distance & 0.021 \\
Ethnic fractionalization & -0.045 \\
\hline
\end{tabular}

Note: Estimates are derived from Table 4.5 holding all other variables constant at their medians

A quick glance at the changes in probabilities in Table 4.7 below shows that consistently, a change of the independent variables (disputed primaries, effective number of parties, and deals) from their minimum to their maximum values is associated with an increased change in the probability to have split outcomes. The change in probability to split, however, is not uniform for each variable and this is explained by the level of significance and the values assigned to the variable from the regression (compare Tables 4.5 and 4.6). For instance, a change of effective number of parties from its minimum to its maximum is associated with about 0.72 change in the chance of split outcome while disputed primaries and deals are associated with about 0.3 and 0.14 chances of split where they were changed from their minimum to maximum values. The rest are associated with lesser values. It is also significant to note that volatility, second to first loser ratio (SF-ratio), and ethnic fractionalization have negative signs. This means that when any of them is 
changed from its minimum to maximum, we should expect a fall in the probability to realize a split outcome.

Table 4.7: Percentage of Split Constituencies vs. Parliamentary Disputed Primaries 1996 - 2016

\begin{tabular}{|c|c|c|c|}
\hline Year & Constituencies & Disputed Primaries (\%) & Split Outcomes (\%) \\
\hline 1996 & 200 & 10.00 & 7.50 \\
\hline 2000 & 200 & 6.00 & 8.00 \\
\hline 2004 & 230 & 8.30 & 8.78 \\
\hline 2008 & 230 & 8.30 & 9.60 \\
\hline 2012 & 275 & 9.50 & 9.50 \\
\hline 2016 & 275 & 13.50 & 10.50 \\
\hline
\end{tabular}

Source: Created by author using data from Election Passport and Ghana Electoral Commission

As a prelude into the discussion section, it pays taking a quick glance at couple of illustrations both tabular and pictorial that substantiate the results from the logistic regression. First, Table 4.8 below created from extracts pulled out of the aggregate electoral data used to run the regression provide visual evidence showing that split outcomes have come to remain an enduring feature of the Ghanaian electoral "system." Brunell \& Grofman (2009) found that

Table 4.8: Presidential and Parliamentary Winners and Runners-Up 1992 - 2016

\begin{tabular}{|c|c|c|c|c|c|c|c|}
\hline & 1992 & 1996 & 2000 & 2004 & 2008 & 2012 & 2016 \\
\hline $\begin{array}{l}\text { Presidential } \\
\text { Winner }\end{array}$ & $\begin{array}{l}\text { NDC } \\
58.4 \%\end{array}$ & $\begin{array}{l}\text { NDC } \\
57.4 \%\end{array}$ & $\begin{array}{l}\text { NPP } \\
48.2 \%\end{array}$ & $\begin{array}{l}\text { NPP } \\
52.5 \%\end{array}$ & $\begin{array}{l}\text { NPP } \\
49.32 \%\end{array}$ & $\begin{array}{l}\text { NDC } \\
50.6 \%\end{array}$ & $\begin{array}{l}\text { NPP } \\
53.7 \%\end{array}$ \\
\hline $\begin{array}{l}\text { Parliamentary } \\
\text { Winner }\end{array}$ & $\begin{array}{l}\text { NDC } \\
94.5 \%\end{array}$ & $\begin{array}{l}\text { NDC } \\
66.5 \%\end{array}$ & $\begin{array}{l}\text { NPP } \\
50.0 \%\end{array}$ & $\begin{array}{l}\text { NPP } \\
55.7 \%\end{array}$ & $\begin{array}{l}\text { NDC } \\
50.4 \%\end{array}$ & $\begin{array}{l}\text { NDC } \\
53.8 \%\end{array}$ & $\begin{array}{l}\text { NPP } \\
61.5 \%\end{array}$ \\
\hline $\begin{array}{l}\text { Presidential } \\
\text { Runner-up }\end{array}$ & $\begin{array}{l}\text { NPP } \\
30.3 \%\end{array}$ & $\begin{array}{l}\text { NPP } \\
39.6 \%\end{array}$ & \begin{tabular}{|l|} 
NDC \\
$44.5 \%$ \\
\end{tabular} & $\begin{array}{l}\text { NDC } \\
44.6 \%\end{array}$ & $\begin{array}{l}\text { NDC } \\
47.8 \%\end{array}$ & $\begin{array}{l}\text { NPP } \\
47.8 \%\end{array}$ & \begin{tabular}{|l|} 
NDC \\
$44.5 \%$ \\
\end{tabular} \\
\hline $\begin{array}{l}\text { Parliamentary } \\
\text { Runner-up }\end{array}$ & $\begin{array}{l}\mathrm{NCP} \\
4.0 \%\end{array}$ & $\begin{array}{l}\text { NPP } \\
30.8 \%\end{array}$ & $\begin{array}{l}\text { NDC } \\
46.0 \%\end{array}$ & $\begin{array}{l}\text { NDC } \\
40.9 \%\end{array}$ & $\begin{array}{l}\text { NPP } \\
46.5 \%\end{array}$ & $\begin{array}{l}\text { NPP } \\
44.7 \%\end{array}$ & $\begin{array}{l}\text { NDC } \\
38.5 \%\end{array}$ \\
\hline $\begin{array}{l}\text { Presidential Run- } \\
\text { off winner }\end{array}$ & & & $\begin{array}{l}\text { NPP } \\
56.9 \% \\
\end{array}$ & & $\begin{array}{l}\text { NDC } \\
50.5 \%\end{array}$ & & \\
\hline $\begin{array}{l}\text { Presidential Run- } \\
\text { off second placed }\end{array}$ & & & $\begin{array}{l}\mathrm{NDC} \\
43.1 \%\end{array}$ & & $\begin{array}{l}\text { NPP } \\
49.5 \%\end{array}$ & & \\
\hline
\end{tabular}

Source: Created by author using data from Election Passport and Ghana Electoral Commission

between 1900 and 2004, a number of districts exhibited split outcomes for President and for representatives in U.S. House. The number of split districts during this period was between five percent and forty percent of all districts. The pictorials provided here, in the case of Ghana, also 
show that between 1996 and 2016, the country recorded between $7.5 \%$ and $10.5 \%$ split outcomes. It is interesting to see the connection between disputed primaries in parliamentary elections and split outcomes in the case of Ghana where increase in disputed primaries is associated with an increase in split outcome.

Figure 4.1: Percentage of Vote Share and Seat Share for Winning Party 1996 - 2016

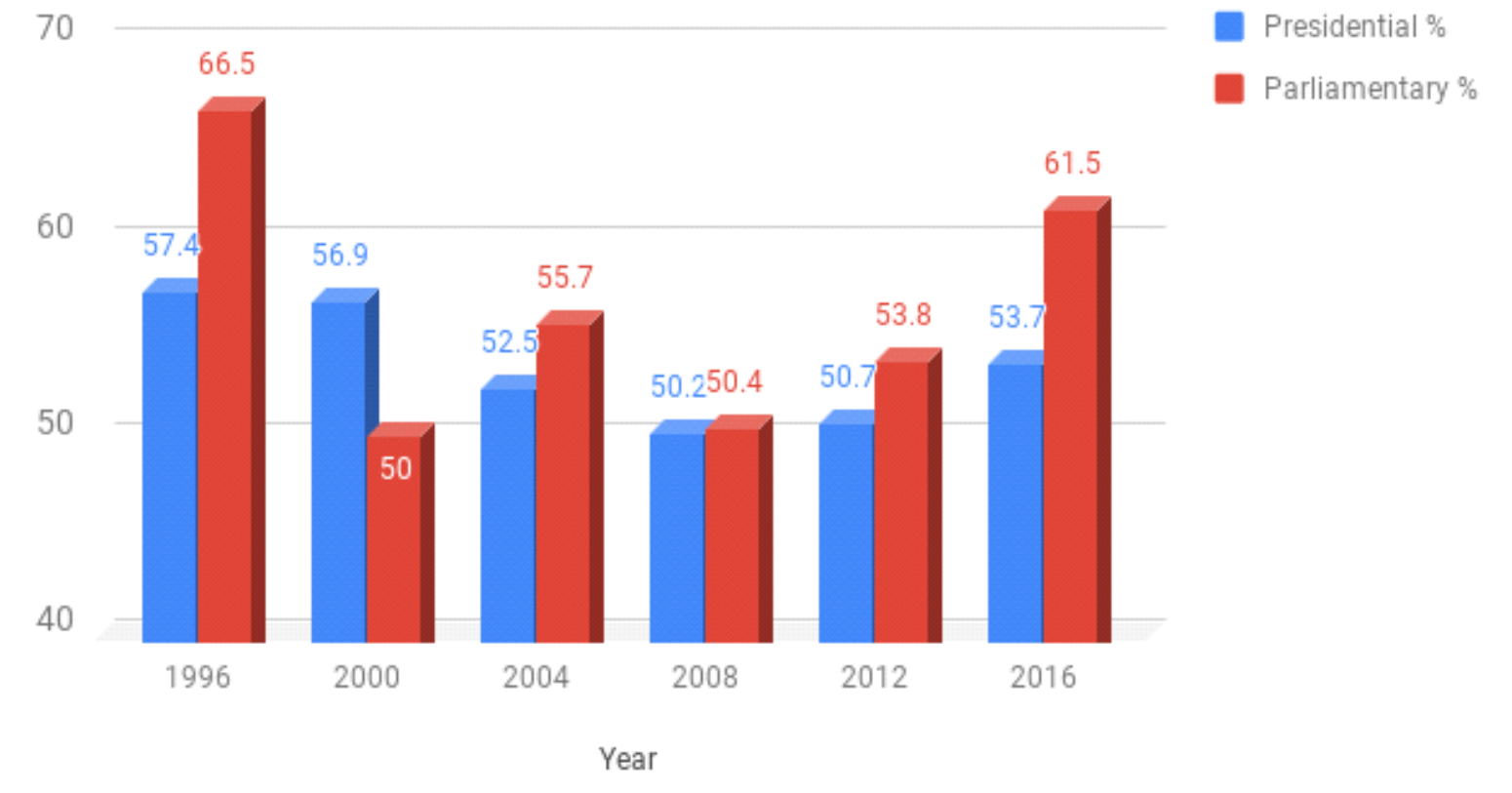

Source: Created by author using data from Election Passport and Ghana Electoral Commission

It is significant to note that unlike other jurisdictions, such as the United States and Brazil where split outcomes occur with regular frequency and often create divided government, in Ghana, the phenomenon has not created divided government, at least for the period under review. As shown by Table 4.8 and Figure 4.1 above, between 1996 and 2016, the party that wins the presidential race also wins parliamentary majority. If we were to add the 1992 elections, the split outcome would have been bigger because in that year, the presidential election was held on November 3, 1992 and the parliamentary elections scheduled for December 8, 1992. When the presidential results were declared, all the major opposition parties raised allegations of vote rigging by the ruling military government that had ruled the country from January 1982 to 1992. 
The military leader (Flt Lt. Jerry Rawlings) was contesting and at the same time "supervising the elections" (Ayee 1997, 1998; Boafo-Arthur 2006; Commonwealth Secretariat 1992; Debrah 2011; Drah 1998; Gyimah-Boadi 2009; Oquaye 1998). As a result, all the opposition parties boycotted the parliamentary election. It was only parties allied to the ruling military government who contested the parliamentary election. In the Ashanti Region for instance, the opposition NPP had won 26 out of the 33 constituencies during the presidential race and had won a number of constituencies in other regions. However, because the opposition boycotted the parliamentary race, all the 33 seats of Ashanti were won by the NDC. Thus, in 1992 elections, there were so many split outcomes because the opposition boycotted parliamentary election and it is for this reason that many scholars do not add the 1992 elections when they consider Ghana. Of course, election passport does not have the 1992 result in its dataset. The major takeaway from this point is that, in Ghana, since the 1996 elections, though there is consistent split outcome, the party that wins the presidential race always wins the parliamentary majority.

\subsubsection{Discussion}

From the logistic regression output and the accompanying figures and tables, the coordination driven split outcome appears to have reasonable merit. First, the fact that split outcomes have become a recurrent phenomenon in Ghanaian electoral politics and always the party that wins the presidency also wins parliamentary majority buttresses the case of coordinationoriented splitting. Table 4.8 shows that the party that commands parliamentary majority pulls not less than 50 percent of the legislative seats while the constitution requires the winner of the presidential race to have at least 50 percent plus one votes (Asamoah 2014; Ayee 1997, 1998, 2002; Boafo-Arthur 2006; Frempong 2017). In fact, Ghana is a two-party state where the two major parties have consistently together pulled between 93 to 98 percent of the valid votes cast 
since 1992 when the country returned to democracy (Ayee 1997, 1998; Boafo-Arthur 2006; Daddieh 2011; Frempong 2017). It was only in 1992 where the opposition parties boycotted the parliamentary election that the NCP, one of the allies of the NDC, placed second and secured four percent of the parliamentary seats after the NDC had ceded some constituencies unopposed to the NCP to contest (Asamoah 2014; Frempong 2017). Otherwise, it has been straight contest between the NDC and the NPP. In the 2000 elections when there was presidential runoff between the Vice President of the ruling NDC and the candidate from the opposition NPP, all the opposition parties unanimously declared their support for the NPP candidate (Asamoah 2014; Frempong 2017; Smith 2002b). Their reason was twofold; first to jointly wrestle power from the (P)NDC which had governed Ghana between 1982 and 1992 as military government and between 1993 and 2000 as a democratic government (Frempong 2017; Smith 2002b). Second, they rationalized that the NPP had won $50 \%$ of the parliamentary seats and leading the presidential contest by $48.2 \%$ while the NDC had only $46.0 \%$ of parliamentary seats and trailing behind the NPP in the presidential race by $44.5 \%$. Therefore, supporting the NDC to win the presidential race will produce divided government that will make governance difficult in Ghana's young democracy (Ayee 2002; Darkwa 2019; Frempong 2017). Given the precedent of the 2000 presidential runoff, in 2008 when there was another presidential runoff between the NPP and the NDC, the other opposition parties went by similar argument that because the NDC had won parliamentary majority of 50.4\% against the NPP's $46.5 \%$, the NDC should be supported in the presidential runoff though the NPP candidate was leading by $49.34 \%$ to $47.8 \%$. At the end of the 2008 runoff, the NDC eventually wrestled power from the ruling NPP candidate by a close margin of $50.5 \%$ to $49.5 \%$. Thus, elite coordination and or miscoordination can explain the phenomenon of split outcome. 
Second, other narratives to support the statistical basis for the coordination driven split ticket and hence, split outcome are numerous, at least for Ghana. Going by the argument in support of the proponents of (mis)coordination ticket splitting, many instances of ticket splitting, and split outcomes can be traced to coordination problems. For instance, Smith (2002b) observed that in the 2000 elections, the ruling NDC lost some safe seats in its strongholds either because of unfair competition, the decision not to hold primaries, or endorsing sitting MPs as consensus candidates (Asamoah 2014; Debrah 2014). In such circumstances, the NDC lost four of its seats to party members who were disappointed nomination seekers that contested the elections as independents (Bob-Milliar \& Bob-Milliar 2010; Daddieh \& Bob-Milliar 2014; Debrah 2014; Frempong 2017; Smith 2002a). There were other instances where some of the independent contestants had failed to win but they facilitated the victory of the opposition party because they divided the party's votes (Daddieh \& Bob-Milliar 2014; Debrah 2014; Frempong 2017). In respect of hypothesis two which touches on exceeding the district magnitude, most of the smaller parties such as the CPP, PNC, GCPP, PPP, DFP are all socialist that trace their origin to the Nkrumah's CPP. They all contest as separate parties and receive an insignificant vote share. The coordination problem is not unique to the smaller parties but to the dominant NDC and NPP who have witnessed splinter groups and independent contestants facilitating the political pendulum that has enabled the three turnovers the country has witnessed between 2000 and 2016.

Volatility has been a major source of party system change and stability (something that causes vote share of parties) in many jurisdictions. In established democracies, researchers have found voters to be responsible for that (Evans 2002; Pedersen 1979; Rose \& Urwin 1970; Taagepera \& Grofman 2003). In new democracies, however, scholars have found elites to be responsible (Birch 2003; Moser \& Scheiner 2009; Tavits 2008) while scholars whose work center 
on strategic coordination found both elites and voters to be responsible (Cox 1997; Kitschelt et al. 1999; Rose \& Munro 2003). This chapter, which is based on strategic coordination, has found both elite level variables (disputed primaries, ENP, and deals) to be significant as per the fitted logistic results and the changes in probability tables above. The chapter, however did not find support for voter level variables (volatility and SF-ratio). It could, therefore, be concluded that elite-level variables are largely responsible in producing split outcomes which has in most cases altered party vote share. In Ghana, deals have produced split results any time both or either of the contracting parties in electoral alliance involving deal win(s). This is because the nature of the deal often requires one party trading off its parliamentary race for support in the presidential race. Therefore, where one of the contracting parties wins or both win the constituency, in which such deal was arranged, there is split outcome. It was through such deals that minor parties like the NCP, PCP, CPP and EGLE have had parliamentary representation between 1993 and 2016 (Darkwa 2019; Frempong 2017). We know that where split outcomes occur, there is at least some split-ticket voting in that constituency. That is skirt and blouse outcome is a sign of skirt and blouse voting (Burden and Kimball 2009).

\subsection{CONCLUSION}

In conclusion, split outcomes as per the extant literature is the basis for divided government in many countries (Alesina and Rosenthal 1995; Ames et al 2009; Burden and Kimball 2009; Fiorina 1992, 1996). However, in Ghana, there is evidence of split outcomes but the reason why till now the country has not yet experienced divided government is due to elite coordination as explained above. This has made Ghana unique in the sense that in two instances (2000 and 2008) where there were opportunities for divided government, the political elite had argued against it and have coordinated to prevent its occurrence. Again, as shown by Table 4.8 and Figure 4.1 above, in 
all instances, the party that won the presidential contest also won at least a $50 \%$ seat share in parliament. Thus, it could be argued that Ghanaian political elites do not advocate ticket splitting with the intent of causing divided government ${ }^{8}$ at least within the Fourth Republic between 1992 - 2016. The results from the regression output to test the hypotheses in this chapter found statistically significant support for the coordination-induced split outcomes that confirms the theoretical expectations of this research. Certainly, differences in elite coordination within and across constituencies account for variations in ticket splitting and for that matter split outcome. In fact, the entire credit or blame could not be attributable to candidates and elites but to voters as well because, as we have seen both elite level hypotheses and voter level hypotheses are all confirmed by this study. As discussed above, the coordination rule which is the $M+1$ rule governs both strategic entry (for candidates and elites) and strategic voting (for voters). Thus, the nuances and complexity in split outcome is due to variations in elite and voter coordination within and between constituencies.

An important clarification on why Ghana's skirt and blouse voting has not produced divided government needs to be pointed out here. As extensively shown in this chapter and reiterated in the preceding paragraph, Ghanaian political elites, though often advocating skirt and blouse, have both in word and deed moved against divided government ${ }^{7}$. A segment of the media and civil society on the other hand, have supported divided government because they are of the view that divided government would act as checks and balances between the executive and legislative arms of government and lead to good governance. These contrasting views held by the political elites and a cross section of the media and civil society will be discussed in the next chapter that utilizes my fieldwork to examine elite level coordination of ticket splitting. 
In fact, as proponents of divided government have a number of justifications for the concept, such as, it leads to policy moderation, checks and balances each arm of government and places each party in its ideal office - institutional matching (Alesina and Rosenthal 1989, 1995; Fiorina 1992, 1996; Jacobson 1990; Petrocik 1991), split outcomes have their strengths. First, it has been argued that ticket splitting and for that matter, split outcomes, promotes performancebased voting such as economic voting (Debrah 2016; Downs 1957; Fiorina 1981; Helmke 2009). Thus, ticket splitters will cast their votes for politicians who have performed well as well as for competence instead of for partisanship. In Ghana for instance, it has been found that constituencies with split outcomes put political actors especially parliamentarians on their toes to offer responsive and accountable representation to their constituents while areas where voters vote straight ticket receive subpar representation (Asunka 2016, 2017; Fridy 2006; Lindberg \& Morrison 2008; Weghorst \& Lindberg 2013).

Finally, elite coordination especially, and to some extent, voter coordination have helped nurture Ghana's young democracy such that both coordination successes and failures have together shepherded the country to navigate the contours of democratization to the point of realizing three successive transfer of power from one party to the other. In critical instances where the country had to have presidential runoffs between a ruling government and the main opposition party, elites have coordinated to ensure that in both instances, the ruling party loses and hands over power peacefully. Thus, the concept of coordination is such a powerful phenomenon that requires the attention of political actors, electorates, policy makers and watchers of democracy. 


\subsection{REFERENCES}

Abramson, Paul R. 1983. Political Attitudes in America: Formation and Change. New York: Freeman.

Agyeman-Duah, Baffour. 2005. Elections and Electoral Politics in Ghana's Fourth Republic. Accra: Ghana Center for Democratic Development. No. 18.

Alesina, Alberto, and Howard Rosenthal. 1989. "Partisan Cycles in Congressional Elections and the Macroeconomy." American Political Science Review 83.2: 373-398.

Alesina, Alberto, and Howard Rosenthal. 1995. Partisan Politics, Divided Government, and the Economy. Cambridge University Press.

Ames, Barry, Andy Baker, and Lucio R. Renno. 2009. "Split-ticket Voting as the Rule: Voters and Permanent Divided Government in Brazil." Electoral Studies 28.1: 8-20.

Asamoah, Obed Yao. 2014. The Political History of Ghana (1950-2013): The Experience of a Non-Conformist. AuthorHouse.

Asunka, Joseph. 2016. "Partisanship and Political Accountability in New Democracies: Explaining Compliance with Formal Rules and Procedures in Ghana." Research \& Politics 3.1.

Asunka, Joseph. 2017. "Non-Discretionary Resource Allocation as Political Investment: Evidence from Ghana." The Journal of Modern African Studies 55.1 (2017): 29-53.

Ayee, Joseph RA. 1997. “The December 1996 General Elections in Ghana.” Electoral Studies 16.3: 416-427.

Ayee, Joseph RA. 1998. "Election management and democratic consolidation: The Electoral Commission of Ghana" In Ayee, Joseph RA (ed.) The 1996 General Elections and Democratic Consolidation in Ghana. Department of Political Science University of Ghana.

Ayee, Joseph. 2002 "The 2000 General Elections and Presidential Run-Off in Ghana: An Overview." Democratization 9.2: 148-174.

Beck, Paul Allen, Lawrence Baum, Aage R. Clausen, and Charles E. Smith, Jr. 1992. "Patterns and Sources of Ticket Splitting in Subpresidential Voting." American Political Science Review 86:916-28.

Beck, Paul Allen. 1997. Party politics in America. Addison Wesley Publishing Company.

Benoit, Kenneth. 2001. "Two Step Forward, One Steps Back: Electoral Coordination in the Hungarian Elections of 1998." Typescript. Trinity College, Dublin.

Birch, Sarah. 2003. Electoral systems and political transformation in post-communist Europe. Springer.

Boafo-Arthur, Kwame. 2006. "The 2004 General Elections: An Overview”, In Boafo-Arthur, ed., Voting for Democracy in Ghana: The 2004 Elections in Perspective, Vol. 1. Accra: Freedom Publications, pp. 33-58.

Bob-Milliar, George M. 2012. "Political party activism in Ghana: factors influencing the decision of the politically active to join a political party." Democratization 19.4: 668-689. 
Bob-Milliar, George M., and Gloria K. Bob-Milliar. 2010. "The Economy and Intra-Party Competition: Presidential Primaries in the New Patriotic Party of Ghana." African Review of Economics and Finance 1.2: 51-71.

Brace, Kimball W. 1993. The Election Data Book: A Statistical Portrait of Voting in America, 1992. Lanham, MD: Beman Press.

Brunell, Thomas L., and Bernard Grofman. 2009. "Testing sincere versus strategic split-ticket voting at the aggregate level: Evidence from split house-president outcomes, 1900-2004." Electoral Studies 28.1: 62-69.

Burden, Barry C., and David C. Kimball. 1998. "A New Approach to the Study of Ticket Splitting." American Political Science Review 92:533-44.

Burden, Barry C., and David C. Kimball. 2009. Why Americans Split their Tickets: Campaigns, Competition, and Divided Government. University of Michigan Press.

Burden, Barry C., and Gretchen Helmke. 2009. "The Comparative Study of Split-Ticket Voting." Electoral Studies 28.1: 1-7.

Burnham, Walter Dean. 1965. "The changing shape of the American political universe." American Political Science Review 59.1: 7-28.

Campbell, Angus, and Warren E. Miller. 1957. "The motivational basis of straight and Split-Ticket Voting.” American Political Science Review 51.2: 293-312.

Campbell, Angus. 1960. "Surge and Decline: A Study of Electoral Change." Public Opinion Quarterly 24.3: 397-418.

Commonwealth Secretariat. 1992. "The Presidential Elections in Ghana, November 3, 1992." The Report of the Commonwealth Observer Group.

Converse, Philip E. 1964. "The Nature of Belief Systems in Mass Publics". In David Apter. Ideology and Discontent. New York: Free Press.

Cox, Gary W. 1997. Making Votes Count: Strategic Coordination in the World's Electoral Systems. Cambridge University Press.

Cox, Gary W. 1999. "Electoral rules and electoral coordination." Annual Review of Political Science 2.1: 145-161.

Cox, Gary W. 2005. "Electoral Institutionals and Political Competition. Coordination, Persuasion and Mobilization." In Claude Ménard and Mary M. Shirley (eds.) Handbook of New Institutional Economics. The Netherlands: Springer.

Cox, Gary W. 2006. How Electoral Reform Might Affect the Number of Political Parties in the Netherlands. Acta Politica 41: 133-45.

Cummings, Milton C., Jr. 1966. Congressmen and the Electorate: Elections for the U.S. House and the President, 1920-1964. New York: Free Press. 
Daddieh, Cyril K., and George M. Bob-Milliar. 2014. "Ghana: The African Exemplar of an Institutionalized Two-Party System?" Party systems and democracy in Africa. Palgrave Macmillan, London. 107-128.

Daddieh, Cyril. 2011. "Democratic Consolidation Without a Second Turnover: Ghana's Remarkable 2004 Elections." In Abdoulaye Saine, Boubacar N'Diaye, and Mathurin Houngnikpo (eds.) Elections and Democratization in West Africa 1990-2009. Trenton, New Jersey: Africa World Press

Darkwa, Samuel K. 2019. “(Mis)coordination: Why Would Ghanaian Political Actors and Political Parties Strategically Encourage Split-Ticket Voting?" In Ghanaian Politics and Political Communication. Edited by Obeng-Gyasi, Samuel and Emmanuel Debrah. [forthcoming] London: Rowman and Littlefield.

Debrah, Emmanuel. 2011. "Measuring Governance Institutions' Success in Ghana: The Case of the Electoral Commission, 1993-2008." African Studies 70.1: 25-45.

Debrah, Emmanuel. 2014. "The Politics of Decentralization in Ghana's Fourth Republic." African Studies Review 57.1: 49-69.

Debrah, Emmanuel. 2016. "The Ghanaian Voter and the 2008 General Election." Politikon 43.3: 371-387.

Downs, Anthony. 1957. An Economic Theory of Democracy. New York: Addison Wesley.

Drah, Francis K. 1998. “The 1996 Elections and Democratization: A Case Study of Okaikoi.” In Ayee, Joseph RA (ed.) The 1996 General elections and democratic consolidation in Ghana. Department of Political Science University of Ghana.

Duverger, Maurice. 1954. Political Parties: Their Organization and Activity in The Modern State. London: Methuen.

EC-Ghana. 1996. "The 1996 Presidential Results" Electoral Commission Ghana. Retrieved September 20, 2018, from http://www.thumbsapp.com.gh/

EC-Ghana. 2000. "The 2000 Presidential Results" Electoral Commission Ghana. Retrieved September 20, 2018, from http://www.thumbsapp.com.gh/

EC-Ghana. 2004. “The 2004 Presidential Results" Electoral Commission Ghana. Retrieved September 20, 2018, from http://www.thumbsapp.com.gh/

EC-Ghana. 2008. "The 2008 Presidential Results" Electoral Commission Ghana. Retrieved September 20, 2018, from http://www.thumbsapp.com.gh/

EC-Ghana. 2012. "The 2012 Presidential Results" Electoral Commission Ghana. Retrieved September 20, 2018, from http://www.thumbsapp.com.gh/

EC-Ghana. 2016. “The 2016 Presidential Results" Electoral Commission Ghana. Retrieved September 20, 2018, from http://www.thumbsapp.com.gh/

Evans, Jocelyn AJ. 2002. "In Defence of Sartori: Party System Change, Voter Preference Distributions and Other Competitive Incentives." Party Politics 8.2: 155-174. 
Feigert, Frank B. 1979. "Illusions of Ticket Splitting." American Politics Quarterly 7.4: 470-488.

Ferrara, Federico, Erik Herron, and Misa Nishikawa. 2005. Mixed electoral systems: Contamination and its consequences. Springer.

Fiorina, Morris P. 1981. Retrospective Voting in American National Elections. Yale University Press.

Fiorina, Morris P. 1992. "An Era of Divided Government." Developments in American politics. Palgrave, London. 324-354.

Fiorina, Morris P. 1996. Divided Government, Second Ed. Allyn \& Bacon, Needham Heights, MA.

Frempong, Alexander Kaakyire Duku. 2017. Elections in Ghana: 1951 - 2016. Digibooks Ghana Ltd.

Fridy, Kevin S. 2006. "The Elephant, Umbrella, and Quarrelling Cocks: Disaggregating Partisanship in Ghana's Fourth Republic.” African Affairs 106.423: 281-305.

Gaines, Brian J. 1999. "Duverger's Law and the Meaning of Canadian Exceptionalism." Comparative Political Studies 32.7: 835-861.

Ghana. Statistical Service. 1995. Ghana living standards survey. Ghana Statistical Service.

Ghana. Statistical Service. 2000. Ghana living standards survey. Ghana Statistical Service.

Ghana. Statistical Service. 2008. Ghana living standards survey. Ghana Statistical Service.

Ghana. Statistical Service. 2014. Ghana living standards survey. Ghana Statistical Service.

Golder, Sona Nadenichek. 2006. The Logic of Pre-Electoral Coalition Formation. Ohio State University Press.

Graham, Emmanuel, et al. 2017. "The Third Peaceful Transfer of Power and Democratic Consolidation in Ghana." Journal of Pan African Studies 10.5.

Gschwend, Thomas, Ron Johnston, and Charles Pattie. 2003. "Split-ticket Patterns in MixedMember Proportional Election Systems: Estimates and Analyses of their Spatial Variation at the German Federal Election, 1998." British Journal of Political Science 33.1: 109-127.

Guinjoan, Marc. 2016. Parties, Elections and Electoral Contests: Competition and Contamination Effects. Routledge.

Gunther, Richard. 1989. "Electoral Laws, Party Systems, and Elites: The Case of Spain." American Political Science Review 83.3: 835-858.

Gyimah-Boadi, E. 2009. “Another Step Forward for Ghana.” Journal of Democracy 20(2).

Helmke, Gretchen. 2009. "Ticket-Splitting as Electoral Insurance: The Mexico 2000 Elections." Electoral Studies 28.1: 70-78.

Herron, Erik S., and Misa Nishikawa. 2001. "Contamination Effects and the Number of Parties in Mixed-Superposition Electoral Systems.” Electoral Studies 20.1: 63-86. 
Herron, Erik S., Kuniaki Nemoto, and Misa Nishikawa. 2018. "Reconciling Approaches in the Study of Mixed-Member Electoral Systems." In Erik S. Herron, Robert J. Pekkanen, and Matthew Soberg Shugart (eds.). Oxford Handbook of Electoral Systems. Oxford: Oxford University Press.

Huntington, Samuel P. 1991. "Democracy's Third Wave." Journal of Democracy 2.2: 12-34.

Jacobson, Gary C. 1990. The Electoral Origins of Divided Government: Competition in US House Elections, 1946-1988. Westview Press.

Johnston, Richard J., and Charles J. Pattie. 1991. "Tactical voting in Great Britain in 1983 and 1987: an alternative approach.” British Journal of Political Science 21.1: 95-108.

Johnston, Ron, and Charles Pattie. 2003. "Evaluating an Entropy-Maximizing Solution to the Ecological Inference Problem: Split-Ticket Voting in New Zealand, 1999." Geographical Analysis 35.1: $1-23$.

Kinder, Donald R. 1983. "Diversity and Complexity in American Public Opinion." Political Science: The State of The Discipline: 389-425.

King, Gary, Martin A. Tanner, and Ori Rosen. 2004. Ecological Inference: New Methodological Strategies. Cambridge University Press.

King, Gary. 2013. A Solution to the Ecological Inference Problem: Reconstructing Individual Behavior from Aggregate Data. Princeton University Press.

Kitschelt, Herbert, et al. 1999. Post-Communist Party Systems: Competition, Representation, and Inter-Party Cooperation. Cambridge University Press.

Kuenzi, Michelle, and Gina Lambright. 2001. "Party System Institutionalization in 30 African Countries." Party Politics 7.4: 437-468.

Kumah-Abiwu, Felix. 2017. "Issue Framing and Electoral Violence in Ghana: A Conceptual Analysis." Commonwealth \& Comparative Politics 55.2: 165-186.

Laakso, Markku, and Rein Taagepera. 1979. "Effective Number of parties: A Measure with Application to West Europe." Comparative Political Studies 12.1 (1979): 3-27.

Lindberg, Staffan I. 2007. "Institutionalization of Party Systems? Stability and Fluidity Among Legislative Parties in Africa's Democracies." Government and Opposition 42.2: 215-241.

Lindberg, Staffan I. 2013. "Have the Cake and Eat It: The Rational Voter in Africa." Party Politics 19.6: $945-961$.

Lindberg, Staffan I., and Minion KC Morrison. 2008 "Are African Voters Really Ethnic or Clientelistic? Survey Evidence from Ghana.” Political Science Quarterly 123.1: 95-122.

Mainwaring, Scott, and Timothy Scully. 1995. "Introduction. Party Systems in Latin America" and "Conclusion. Party and Democracy in Latin America, Different Patterns, Common Challenges." In Timothy Scully R. Building Democratic Institutions: Party Systems in Latin America. Stanford University Press 
Mair, Peter. 1997. Party System Change: Approaches and Interpretations. Oxford University Press.

McFadden, Daniel. 1974. "Frontiers in Econometrics, chapter Conditional logit analysis of qualitative choice behavior."

McFadden, Daniel. 1977. Quantitative Methods for Analyzing Travel Behavior of Individuals: Some Recent Developments. Berkeley: Institute of Transportation Studies, University of California.

Mebane, Walter R. 2000. "Coordination, Moderation, and Institutional Balancing in American Presidential and House Elections.” American Political Science Review 94.1: 37-57.

Moser, Robert G., and Ethan Scheiner. 2009. "Strategic Voting in Established and New Democracies: Ticket Splitting in Mixed-Member Electoral Systems." Electoral Studies 28.1: 5161.

Navia, Patricio, and José Luis Saldaña. 2015. "Mis-Coordination and Political Misalignments in Ticket-Splitting: The Case of Chile, 2005-2009. “Contemporary Politics 21.4: 485-503.

Neuman,W. Russell. 1986. The Paradox of Mass Politics. Cambridge, Mass.: Harvard University Press.

Oquaye, Mike 1998. "Human Rights and the 1996 Elections" In Ayee, Joseph RA. (ed.) The 1996 General Elections and Democratic Consolidation in Ghana. Department of Political Science University of Ghana.

Pedersen, Mogens N. 1979. "The Dynamics of European Party Systems: Changing Patterns of Electoral Volatility.” European Journal of Political Research 7.1: 1-26.

Petrocik, John R. 1991 "Divided Government: Is it All in the Campaigns?" The Politics of Divided Government: 13-38.

Petrocik, John R., and Joseph Doherty. 1996. "The Road to Divided Government: Paved without Intention." In Peter F. Galderisi (ed.) Divided Government: Change, Uncertainty, and the Constitutional Order. Lanham, MD: Rowman and Littlefield.

Pettai, Vello, and Marcus Kreuzer. 2001. "Institutions and Party Development in the Baltic States." Party Development and Democratic Change in Post-Communist Europe: 107-125.

Power, Timothy J. 2000. "Political Institutions in Democratic Brazil: Politics as a Permanent Constitutional Convention." Democratic Brazil: 17-35.

Randall, Vicky, and Lars Svåsand. 2002. "Party Institutionalization in New Democracies." Party Politics 8.1: 5-29.

Resnick, Danielle. 2013. "Do Electoral Coalitions Facilitate Democratic Consolidation in Africa?" Party Politics 19.5: 735-757.

Riker, William H. 1962. The Theory of Political Coalitions. Yale University Press. 
Roscoe, Douglas D. 2003. "The Choosers or the Choices? Voter Characteristics and the Structure of Electoral Competition as Explanations for Ticket Splitting." Journal of Politics 65.4: 11471164.

Rose, Richard, and Derek W. Urwin. 1970. "Persistence and Change in Western Party Systems Since 1945.” Political Studies 18.3: 287-319.

Rose, Richard, and Neil Munro. 2003. Elections and parties in new European democracies. Washington, DC: CQ Press.

Rusk, Jerrold G. 1970. "The Effect of the Australian Ballot Reform on Split Ticket Voting: 18761908." American Political Science Review 64.4: 1220-1238.

Saad, Lydia. 1995. "Budget Standoff Not Welcomed by Most Americans." Gallup Poll Monthly 362: 5-7.

Scully, Timothy R. 1995. Building Democratic Institutions: Party Systems in Latin America. Stanford University Press.

Shugart, Matthew Soberg. 1995. "The Electoral Cycle and Institutional Sources of Divided Presidential Government." American Political Science Review 89.2: 327-343.

Singer, Matthew M., and Laura B. Stephenson. 2009. “The Political Context and Duverger's Theory: Evidence at the District Level." Electoral Studies 28.3: 480-491.

Smith, Daniel. 2002a. “Ghana's 2000 elections: consolidating multi-party democracy.” Electoral Studies 21.3: 519-526.

Smith, Daniel. 2002b. "Consolidating democracy? The structural underpinnings of Ghana's 2000 elections." The Journal of Modern African Studies 40.4: 621-650.

Taagepera, Rein, and Bernard Grofman. 2003. "Mapping the Indices of Seats-Votes Disproportionality and Inter-Election Volatility.” Party Politics 9.6: 659-677.

Tavits, Margit. 2008. "On the Linkage Between Electoral Volatility and Party System Instability in Central and Eastern Europe.” European Journal of Political Research 47.5: 537-555.

Toole, James. 2000. “Government Formation and Party System Stabilization in East Central Europe." Party Politics 6.4: 441-461.

Van Biezen, Ingrid. 2003. Political Parties in New Democracies: Party Organization in Southern and East-Central Europe. Springer.

Wahman, Michael. 2014. "Electoral Coordination in Anglophone Africa." Commonwealth \& Comparative Politics 52.2: 187-211.

Weghorst, Keith R., and Staffan I. Lindberg. 2013. "What Drives the Swing Voter in Africa?" American Journal of Political Science 57.3: 717-734.

Yobo, Eric, and Ransford Edward Van Gyampo. 2015. "Third Parties and Electoral Politics in Ghana's Fourth Republic.” J. Pol. \& L.8: 7.

Zaller, John. 1992. The Nature and Origins of Mass Opinion. New York: Cambridge University Press. 


\subsection{Notes}

1. Ecological inference fallacy is the mistake associated with inferring individual level behavior from aggregate data. For instance, relying on aggregate electoral result to deduce individual-level attributes such as ticket splitting

2. The mediating factors are institutional and social contexts that influence elite coordination. For instance, elite coordination in single member districts (SMDs) may differ from elite coordination in multimember districts (MMDs) (Guinjoan 2016; Herron and Nishikawa 2001, 2005; Ferrara 2004). In Ghana for example, elite coordination in SMDs are such that, often, one party defers the parliamentary race for its ally for a corresponding support in the presidential race in that constituency.

3. Part of this dissertation is expected to be published in London by Rowman and Littlefield International Limited.

4. Given that most of the examples given about divided government relate to the United States due to its unique Constitution that provides separate roles for the various arms of government, I will discuss the theory of divided government as it pertains to the US. I will also discuss how it is in Brazil and Mexico.

\section{5. http://www.electionpassport.com/}

6. To compute ENP, the first step is to find each party's vote or seat share (that is the percentage of votes or seats received). Second, square each party's vote or seat share and add up the squares. Finally, find the reciprocal of the sum of squares.

7. I got most of my data from Frempong's (2017) Frempong, Alexander Kaakyire Duku. 2017. Elections in Ghana: 1951 - 2016. Digibooks Ghana Ltd. and just a few from Osei, Anja. 2012. Party-Voter Linkage in Africa: Ghana and Senegal in Comparative Perspective. Springer Science \& Business Media.

The data from Frempong's (2017) Osei (2012) were supplemented with journal publications and by media reports. Among them are:

Bob-Milliar, George M. 2012. "Political party activism in Ghana: factors influencing the decision of the politically active to join a political party." Democratization 19.4: 668-689.

Bob-Milliar, George M., and Gloria K. Bob-Milliar. 2010. "The Economy and Intra-Party Competition: Presidential Primaries in the New Patriotic Party of Ghana." African Review of Economics and Finance 1.2: 51-71.

Daddieh, Cyril K., and George M. Bob-Milliar. 2014. "Ghana: The African Exemplar of an Institutionalized Two-Party System?" Party systems and democracy in Africa. Palgrave Macmillan, London. 107-128. 
Debrah, Emmanuel. 2014. "Intra-Party Democracy in Ghana's Fourth Republic: The Case of the New Patriotic Party and National Democratic Congress." Journal of Power, Politics \& Governance 2.3: $57-75$.

In respect to media reports I try as much as possible to confirm a single story with about two media houses. A media source for party members going independent for instance, that I worked with in respect to members going independent was carried by at least four media houses as "NDC sacks 23 members for going independent". The links to these are given below.

\section{http://citifmonline.com/2016/11/01/ndc-sacks-23-members-for-going-independent/}

\section{http://www.peacefmonline.com/pages/politics/politics/201611/296840.php?page=1}

\section{HYPERLINK}

https://www.ghanaweb.com/GhanaHomePage/NewsArchive/NDC-sacks-23-for-goingindependent-482650

https://www.pulse.com.gh/ece-frontpage/independent-candidates-ndc-sacks-23-parliamentaryaspirants/hbb7z08

8. Though Ghanaian political elites engage in acts that promote skirt and blouse voting, they have done their best to avoid divided government because Flt Lt. Jerry Rawlings' second military coup in December 1981 came shortly after the Third Republican Parliament voted against the president's budget).

Appendix 4.1: Parliamentary Representation in Ghana's Fourth Republic

\begin{tabular}{|c|c|c|c|c|c|c|c|}
\hline $\begin{array}{l}\text { Party/Independent } \\
\text { Date of investiture }\end{array}$ & $\begin{array}{l}\text { First } \\
\text { Parliament } \\
\text { Jan 7, } 1993\end{array}$ & $\begin{array}{l}\text { Second } \\
\text { Parliament } \\
\text { Jan 7, } 1997\end{array}$ & $\begin{array}{l}\text { Third } \\
\text { Parliament } \\
\text { Jan 7, 2001 }\end{array}$ & $\begin{array}{l}\text { Fourth } \\
\text { Parliament } \\
\text { Jan 7, 2005 }\end{array}$ & $\begin{array}{l}\text { Fifth } \\
\text { Parliament } \\
\text { Jan 7, } 2009\end{array}$ & $\begin{array}{l}\text { Sixth } \\
\text { Parliament } \\
\text { Jan 7, } 2013\end{array}$ & $\begin{array}{l}\text { Seventh } \\
\text { Parliament } \\
\text { Jan 7, 2017 }\end{array}$ \\
\hline NDC & $189(94.5)$ & $133(66.5)$ & $92(46.0)$ & $94(46.5)$ & $116(50.4)$ & $148(53.8)$ & $106(38.5)$ \\
\hline NPP & - & $61(30.5)$ & $100(50.0)$ & $128(55.7)$ & $107(46.5)$ & $123(44.7)$ & $169(61.5)$ \\
\hline $\mathrm{NCP}$ & $8(4.0)$ & - & - & - & - & - & - \\
\hline $\mathrm{PNC}$ & - & $1(0.5)$ & $3(1.3)$ & $4(1.7)$ & $2(0.9)$ & $1(0.4)$ & \\
\hline CPP & - & - & $1(0.5)$ & $3(1.3)$ & $1(0.4)$ & & \\
\hline EGLE & $1(0.5)$ & - & - & - & - & - & - \\
\hline PCP & - & $5(2.5)$ & - & - & - & - & - \\
\hline Independent & $2(1.0)$ & - & $4(2.0)$ & $1(0.4)$ & $4(1.7)$ & $3(1.1)$ & - \\
\hline TOTAL & $200(100)$ & $200(100)$ & $230(100)$ & $230(100)$ & $230(100)$ & $275(100)$ & $275(100)$ \\
\hline
\end{tabular}

Source: Compilations from the Election Passport and Electoral Commission of Ghana Databases. Notes: Percentages in parentheses. The seat allocations are as per the general elections conducted prior to the inauguration of Parliament on January 7, and do not consider reallocations due to byelections.

Appendix 4.2: Coding at the Aggregate Level of Analysis 


\begin{tabular}{|c|c|}
\hline Variable & Measurement \\
\hline $\begin{array}{l}\text { Split outcome } \\
\text { (DV) }\end{array}$ & $\begin{array}{l}\text { The main DV is split outcome as such, constituencies with split outcomes were coded as } \\
\text { "1", otherwise coded as "0". }\end{array}$ \\
\hline $\begin{array}{l}\text { Parliamentary } \\
\text { Disputed } \\
\text { Primaries }\end{array}$ & $\begin{array}{l}\text { Since disputed primaries in parliamentary elections are likely to cause split outcome, } \\
\text { every constituency with disputed primaries in parliamentary elections is coded as " } 1 \text { " } \\
\text { otherwise coded as " } 0 \text { " }\end{array}$ \\
\hline Volatility & $\begin{array}{l}\text { I compute electoral volatility for each constituency from the legislative election results } \\
\text { using a modified Pedersen Index which ranges between } 0 \text { and } 1 \text {. I first totaled the change } \\
\text { in each party's vote share in the current and previous election. Second, I added up the } \\
\text { absolute values of the changes in vote shares. Finally, I divided the sum of the absolute } \\
\text { values by two. }\end{array}$ \\
\hline $\begin{array}{l}\text { Effective } \\
\text { number of } \\
\text { parties (ENP) }\end{array}$ & $\begin{array}{l}\text { The ENP is computed from the legislative election results using the vote share of } \\
\text { competing parties in a given constituency. First, I computed the vote share of all the } \\
\text { contestants in a given constituency. Second, I squared each contestant's vote share and } \\
\text { summed up the values. Finally, I computed the reciprocal of sum of squares. }\end{array}$ \\
\hline S-F Ratio & $\begin{array}{l}\text { I generate the SF-Ratio from the legislative election results using the vote ratio between } \\
\text { the second and third placed candidates in a given constituency. In other words, the SF- } \\
\text { Ratio measures the proportion of vote share between the second and first loser in a } \\
\text { constituency. }\end{array}$ \\
\hline Deals & $\begin{array}{l}\text { I measured deal as a dichotomous variable: constituencies with deals are coded as "1", } \\
\text { otherwise coded as "0". }\end{array}$ \\
\hline Regional Effect & $\begin{array}{l}\text { I control for regional effect, as contiguous constituencies are more likely to vote in } \\
\text { identical way. To measure this, I computed the proportion of split outcome at time t- } 1 \text { for } \\
\text { each constituency. In this way each constituency in a region is given the same value. }\end{array}$ \\
\hline Distance & $\begin{array}{l}\text { To control for how legislators' closeness to their constituents may affect split, I use the } \\
\text { distance from the constituency capital in each constituency to the national legislative } \\
\text { house as a measure. }\end{array}$ \\
\hline $\begin{array}{l}\text { Ethnic } \\
\text { fractionalization }\end{array}$ & $\begin{array}{l}\text { I computed ethnic fractionalization using the Herfindahl-Hirschman Index (HHI) by } \\
\text { squaring each ethnic group's population share in that constituency and then found the } \\
\text { sum of those numbers. To obtain the proportion of each ethnic group's population share, } \\
\text { I used the ethnic profile of each constituency as per the appropriate GLSS report. } \\
\text { The GLSS report is given at the regional level. To generate the constituency equivalence, } \\
\text { I used the proportion between the presidential valid votes cast at the regional and } \\
\text { constituency levels. }\end{array}$ \\
\hline
\end{tabular}




\section{CHAPTER 5. ELITE LEVEL OF ANALYSIS}

\subsection{CHAPTER INTRODUCTION}

"Ghana stands to gain, and parliament will produce results for the people through give and take negotiations and proper debates devoid of insults... if we vote wisely and vote skirt and blouse ${ }^{1}$ (Festus Lartey-Adjei, December 7 , 2012).

As you go out to vote on Sunday, I am urging my friends and anyone who really cares about the growth of democracy in Ghana to vote "skirt and blouse". I'd like to have a situation where the president is from 'Party A' but parliament is controlled by 'Party B' or 'Party C'2 (Ato Kwamena Dadzie, December 5, 2008)

Political parties usually have a strong incentive to encourage straight ticket voting so that voters support all their candidates on the ballot. In Ghana, split-ticket voting is so common that it has a special name, "skirt and blouse voting," denoting a two-piece dress instead of one straight dress (Daddieh 2011). Not only do we see evidence of split-ticket voting in some constituencies, but we also see some evidence that parties strategically encourage split-ticket voting under certain conditions. Further, civil society and media may encourage split-ticket voting to achieve certain goals. The above two quotes are mere crumbs of what political party elites and other Ghanaians feed the electorates on in public and in private to shape their voting pattern. In fact, the first statement was attributed to Dr. Abu Sakara, the 2012 Presidential Candidate of the Convention People's Party (CPP). In Chapter 4, the dissertation made a claim backed by data that elite support for skirt and blouse voting aims to achieve certain electoral outcome other than divided government. It is significant to note that both quotes at the beginning of the chapter support how the phenomenon is encouraged. The second quote does something more than merely encouraging skirt and blouse voting. It is actually asking for divided government: that is the presidency and parliament are controlled by different political parties. The quote is actually from someone from the media and civil society who thinks that divided government will create the necessary checks and balances for the executive and legislative arms of government to play a watchdog role which will strengthen Ghana's democracy. Political elites, on the other hand, think otherwise. Though 
they engage in acts that promote skirt and blouse voting, they do not support divided government because Flt Lt. Jerry Rawlings' military coup in December 1981 came shortly after the Third Republican Parliament voted against the president's budget.

This chapter will explore the reasons Ghanaian political elites will generally support skirt and blouse voting or skirt and blouse outcome and thus, contribute to our understanding of splitticket voting, elite behavior, and Ghanaian electoral politics within Ghana's Fourth Republic. It worth stressing that this chapter differs from Chapter 3 in the sense that whereas Chapter 3 focuses on individual voter, this chapter focuses on party elites by trying to address why a party elite or a party card bearing member will vote skirt and blouse. Why would party elites and supporters of a political party want either the party's presidential or parliamentary candidate lose the election in a particular constituency? Why would a presidential and or parliamentary candidate of a political party advocate either overtly or covertly for split-ticket voting? Again, why would a supporter, a member or an official of a political party indeed vote to split the ballot, roll-off the ballot, or abstain? Finally, how has this problem shaped the current distribution of votes and seats share of parties in Ghana? Using fieldwork conducted in Ghana that sampled 303 party elites and few media, civil society leaders and academics in 2017 , the chapter argues that political party officials/political actors tend to do what they feel will serves their best interests. In some cases, their "best interests" may involve a split-ticket outcome.

Further, politicians will advocate for split-ticket voting in situations where coordination breaks down or will deliberately frustrate coordination where they find it to be the most expedient means of facilitating their political goal at a given time. This observation suggests that we can observe conventional coordination which is a harmonious interaction or relationship within a group or among groups of people working together and the reverse of that. I refer to both as 
(mis)coordination to cater for coordination failure and coordination success (Cox 1999; Navia and Saldaña 2015). Thus, political actors are strategic in their choices; they make their choices in response to (in anticipation of) what other actors (competitors and voters) are doing (will do). Employing Cox's (1997, 1999) coordination theory, the chapter further asserts that strategic coordination is a mechanism that political actors employ to communicate their intentions about the direction they expect the elections to go. The electorates are able to decode such cues where political actors employ strategic coordination as communication mechanism because they come with certain observable indicators ${ }^{3}$. It is instructive to note that strategic coordination is carried out within party (intraparty) and between party (interparty) ${ }^{4}$. This chapter will identify the observable indicators of intraparty and interparty coordination cues that party elites create as they engage in strategic coordination and generate testable hypotheses, test them and draw conclusion about how these promote ticket splitting.

The chapter proceeds as follows: the next section, section 5.2, presents findings from the fieldwork conducted in 2017 exclusively for this dissertation. Section 5.3 discusses the strategic coordination theory which is the dissertation's contribution to the ticket splitting literature. The strategic coordination theory is a two-pronged theoretical model used to analyze the phenomenon of ticket splitting especially from elites' perspectives as it relates to intraparty and interparty coordination problems they face in prosecuting their political agenda. Each of these sections will introduce and discuss the appropriate testable hypotheses that capture the observable indicators of intraparty and interparty coordination problems faced by party elites. Section 5.4 discusses alternative explanations with their associated hypotheses: Partisanship, the educational level of the respondents, and whether or not the parties/candidates that respondents identify with contest in a given constituency. Section 5.5 touches on the data and how it was collected, how relevant it is to 
the questions and the theory, as well as how the variables are measured. The section discusses the dependent and independent variables as well as the control variables. The penultimate unit, section 5.6 models the interparty and intraparty coordination theory and presents the results from the logistic regression. This will connect to the discussion segment of the chapter by buttressing the results with stories of coordination problems in Ghana's Fourth Republic. Section 5.7, the final section, summarizes the discussions, points out the importance of the chapter and proposes suggestions and recommendations for future research in the subfield.

\subsection{DISCOVERIES FROM THE FIELDWORK}

The post-election fieldwork conducted in Ghana in 2017 just after the 2016 Ghanaian election offered my research team and I a unique opportunity to uncover several insightful experiences and thoughts from party elites, media persons, civil society and scholars on why skirt and blouse is pervasive in Ghana. These could be classified into: nomination problems, sabotage, local vs national issues, results of government policy, and the effects of interparty coordination on smaller parties vote share. These are briefly discussed under subsections 5.2.1 to 5.2.5 below.

\subsubsection{Nomination Problems}

Our interactions with our research subjects, especially with party elites who were either victims or advocates of skirt and blouse voting/outcome, gave us an opportunity to unearth how party nomination process becomes mechanism for promoting skirt and blouse outcome for several reasons. It came to light that the two major political parties, the NPP and the NDC, have rolled out what they referred to as "affirmative action" politicians to enter parliament. The "affirmative action" has two strands: reduction in the filing fees for beneficiaries and the designation of some constituencies as affirmative constituencies. The 
way these measures create skirt and blouse outcome is that instances where female politicians and those with disability pay reduced filing fees, the level of intraparty competition in those constituencies is compromised at the parliamentary race. That is, because as female politicians and those with disability are made to pay reduced filing fees, their competitors see the action as skewing the system in favor of their opponents and not on the basis of merit. Often, the candidate selected is not able to match the competition from the opponents who may not have the same policy in that constituency. From my respondent's perspective, the most detrimental kind of this policy is designation of a constituency as affirmative constituency. This kind of affirmative action is seen as another kind of imposition of a candidate where women are to be given consideration in a party's stronghold, and it mostly creates problems for the party such that the party often ends up losing a safe seat to opponents.

Other kinds of nomination problems unraveled by the team include instances where party heavy weights, especially those in national, regional, and constituency executive levels, use their positions to support a particular candidate. Similar to this is corruption on the part of party officials who organize the primaries by favoring certain candidates either because those candidates bribe them or because they have special relationship with the candidates. These acts create uneven electoral playing ground among contestants, and those who feel they are unfairly treated often advocate skirt and blouse voting. Often, aggrieved unsuccessful parliamentary nomination seekers who are victims of unfair treatment enter the elections as independent and thus create opportunity for skirt and blouse voting. Respondents 1 and 7 revealed in an interview that, victims of unfair nomination become easy targets to opponents who are prepared to use financial inducement to create skirt and blouse in their opponent's strongholds with the view of making it possible for the financier's party's candidate to win those constituencies ${ }^{6}$. The financial inducement used by 
opponents to create skirt and blouse voting in the recipient's party referred to here as "financing of opposition election campaigns" is of two kinds. The first is where the financier targets some members or plant certain persons in opponent's party for a period of time for those persons to become eligible for that party's parliamentary nomination. As expected, such persons' aim is to do whatever possible to mar the party's nomination process and thus, break the bond of unity that holds the party together. The second type uncovered by this research is where the financier woos aggrieved nomination seekers of opponent parties and support them to contest the election as independents. When this happens, it increases the likelihood of skirt and blouse voting in the recipient's party and a possible win for the financier's legislative candidate because in most instance, party supporters will support their presidential candidate but divide their vote at the legislative race.

\subsubsection{Deliberate Sabotage}

Emanating from the above is the issue of calculated or deliberate sabotage often carried out by aggrieved nomination seekers or persons with presidential or parliamentary ambitions. It was found out that, aggrieved nomination seekers who feel unfairly treated by parties hold that the best way to hurt their party or receive attention is to advocate skirt and blouse voting. Again, persons with parliamentary or presidential ambitions also work against the current occupant of that seat. Such acts often break the party's front, create disaffection among party members and fester intraparty conflicts which produce skirt and blouse voting when left unresolved. Key among persons who harbor parliamentary ambitions are political appointees, such as district or municipal chief executives (DCEs/MCEs), who represent the president and perform ceremonial and executive functions and are often custodians of development projects in those areas. The research found that there are two reasons why DCEs/MCEs would promote skirt and blouse to sabotage the 
member of parliament (MP) in that constituency. First, the position of DCEs/MCEs and that of a minister do not have their tenure backed by the Constitution. Their continuous stay in office is at the discretion of the president who can hire and fire at any time. The MP's tenure, on the other hand, is guaranteed by the Constitution and that is what most politicians prefer. Second, the MPs are often detached from the people by result of the location of their working place which is miles away at the national capital. In terms of presence and visibility, DCEs/MCEs are within the community and their work is often conspicuous to the electorates. Thus, DCEs/MCEs are often seen to "belong" to the constituent while an MP is seen to be too distant from the people. This perception worsens where the MP does not frequent the constituency. The result is that because DCEs/MCEs preferred to be MPs and given their visibility and presence, coupled with their role as the representatives of the president promoting development in the constituency against the MP who is seen to be distant, the DCEs/MCEs are easily able to sabotage the MPs. Again, because there is no term limit for MPs, an MP can be in parliament as long as the constituents are willing to renew the MP's mandate. Consequently, MPs who have had three or more parliamentary terms become targets of sabotage. The result of this is skirt and blouse voting or outcome because the MPs also have some supporters in the constituencies who are likely to vote for the party's presidential candidate and the MP. These calculated sabotages often do not involve the presidential candidates because they are limited to certain constituencies and involve the MP and in-party member(s) who want the MP's seat.

It also came to light that party foot-soldiers who do the leg work for the party at the grassroots to win elections are often promised jobs and positions. However, because most of them do not have the needed skills and qualifications, their parties often fail to honor promises made to them. These party foot-soldiers often register their protest by mobilizing against their parties as 
Samuel K. Darkwa

they also register their dissatisfaction through skirt and blouse often against the candidates who failed to honor their promises. Party foot soldiers often well organize their protest in the constituencies with banners and placards communicating their intentions to their party leadership.

\subsubsection{Local Vs National Issues}

Related to the above is how the phenomenon of skirt and blouse voting relates to party problems classified as local vs national. An interesting observation from the fieldwork is that in Ghana, skirt and blouse voting, in most cases, is directed towards parliamentary candidates and not the presidential candidates. That is, most of the time, it is the parliamentary candidate who suffers from skirt and blouse voting. The reasons here are multifaceted. First, some of the MPs, either before or after their parliamentary quest, might have involved themselves in local problems such as chieftaincy conflicts. This is a local problem and, as such, it is the local politician (MP), not the national politician (president), who suffers for it. It must be pointed out, however, that the local politician can also benefit from skirt and blouse voting; especially where the local politician promotes development projects in that constituency. Furthermore, candidates who do not connect well with their constituents as well as those who do not conduct themselves well attract skirt and blouse voting. Thus, the issue of responsiveness is at the heart of skirt and blouse voting. For instance, a person who promotes development in an area can benefit from skirt and blouse voting. Second, the nomination problems discussed above in section 5.3.1, and its associated sabotage discussed in the preceding section, are largely local problems and thus make voters split from the local politician. These aside, it was found that when there are conflicts in the party at the national level and disciplinary measures are carried out at that level, it unites the party at the grassroots. However, where there are conflicts at the local level and national leadership prescribes disciplinary measures at the local level, it creates confusion and breaks the ranks of the party. These 
observations are context dependent, but they tell us that parties differentiate local and national issues and when they are conflated, create skirt and blouse voting. One of my respondents said this in support of local vs national issues:

"In the 2016, NPP was more divided at the top where their national executives such as Paul Afoko (the National Chairman), Kwabena Agyei Agyepong (General Secretary) and Sammy Crabbe (the Second Vice Chairman) were all suspended. Ironically, this united the party's grassroots especially given that the party has been in opposition for eight years and wanted to come back into power. Again, given that the governing NDC was also having internal division at the grassroots but the president (NDC candidate) and his executives were using NPP's internal division as a campaign issue galvanized the opposition to unite at the grassroots and delivered a sound victory to their party"'

Thus, the takeaway from these points is that local problems often create skirt and blouse that the local politician suffers for.

It is also interesting to note that the local vs national divide can take a twist where the presidential candidate rather than the parliamentary candidate suffers for it. It was found that where there is a disconnect between the party structures and the presidential candidate's campaign team, it incurs the displeasure of the locals who vote against their presidential candidate but for the party's parliamentary candidate. For instance, some of my respondents said the NDC presidential candidate, who was also the incumbent, created a lot of disaffection at the grassroots for using celebrities (movie and music stars) instead of the local executives ${ }^{8}$. Most of these people do not understand the local language, the customs and traditions of the people. These aside, they do not even know the boundaries of constituencies in the country and this angered the locals (regional and national executives) to vote against the president, making him the first to lose his reelection bid. It was also found that most of the logistics of the incumbent president, such as T-shirt distribution, mounting of billboards, were done by the president's team from the national capital. These acts covertly communicated to the local executives that they were not needed and as such most of the campaigns led by celebrities were mere fanfare that did not attract any serious votes. 


\subsubsection{Results of Government Policy}

My interactions with respondents showed how a government policy can cause skirt and blouse voting. The central government had withdrawn allowances from teacher training and nursing training colleges ${ }^{9}$. This and other government policies placed financial burden on all citizens. However, some smart MPs in the president's party clandestinely distanced themselves and rolled out some scholarship funds for their constituents. This reflected in the votes received by these MPs against those of the incumbent president. Thus, the pursuit of certain policies by a government can make its own supporters decide to vote against the party, but if an MP or prospective MP of that party strategically distances himself/herself from that policy, there will be likely ticket splitting. Conversely, skirt and blouse can also be used to reward the president for pursuing certain policies that the electorates approve. On the other hand, they punish the MP for not being responsive to the needs of the constituency.

\subsubsection{The Effects of Interparty Coordination on Smaller Parties' Vote Share}

Analysis of fieldwork showed that though interparty alliance (coordination) between the smaller and the major parties had helped the former to have parliamentary representation between 1992 and 2012, it has weakened the former and the effect is that they have ceded their strongholds to the latter through that coordination. For instance, in the 1992 presidential election, the People's National Convention garnered (PNC) $6.70 \%$, the National Independence Party (NIP) got 2.86\% and the People's Heritage Party received $1.76 \%$ of the total valid votes cast. However, now, all the smaller parties put together are not able to pull $2 \%$ of the votes because the bigger parties have taken over their support base. One of my respondents had this to say:

"The bigger parties when entering alliance with smaller parties do not do favors to the smaller parties because they do not negotiate on areas they know they will win. Rather, they 
negotiate on areas they will lose. For instance, a bigger party will expect you to concede your presidential slot in your stronghold so that it does not contest the parliamentary seat in that constituency. That aside, you both must endorse each other's candidate and get your supporters to campaign and vote. With that, both of you will help each other to win the presidential seat for the bigger party and the parliamentary seat for the smaller party"10.

Respondents 5 and 6 said that, the bigger parties often poach the most qualified candidates of the smaller parties they form alliance with by giving them ministerial appointments ${ }^{11}$. This, to them, has resulted in the abysmal performance of the smaller parties. It could be argued, however, that contrary to this, the adoption of a pure SMD system without a majority runoff rule coupled with elite coordination largely account for the displacement of the minor parties in Ghana (Cox 1997; Duverger 1954). Tables 5.1 and 5.2 below show the vote share and seat share of contesting parties in the presidential and legislative elections between 1996 and 2016. A quick glance at them shows a trend of decline in the support for the smaller parties and sustained growth of the two main parties; the NPP and the NDC.

5.1 Presidential Election Results 1996 - 2016

\begin{tabular}{|l|l|r|r|}
\hline Year & Party & \multicolumn{1}{|c|}{ Votes } & Percentage (\%) \\
\hline 1996 & National Democratic Congress (NDC) & $4,101,674$ & 57.40 \\
\hline & New Patriotic Party (NPP) & $2,829,726$ & 39.60 \\
\hline & People's National Convention (PNC) & 214,373 & 3.00 \\
\hline & & & \\
\hline $2000\left(1^{\text {st }}\right.$ Round) $)$ & New Patriotic Party (NPP) & $3,131,739$ & 48.17 \\
\hline & National Democratic Congress (NDC) & $2,895,575$ & 44.54 \\
\hline & People's National Convention (PNC) & 189,659 & 2.92 \\
\hline & Convention People's Party (CPP) & 115,641 & 1.78 \\
\hline & National Reform Party (NRP) & 78,629 & 1.21 \\
\hline & Great Consolidated Popular Party (GCPP) & 67,504 & 1.04 \\
\hline & United Ghana Movement (UGM) & 22,123 & 0.34 \\
\hline & & & 56.90 \\
\hline $2000\left(2^{\text {nd }}\right.$ Round) & New Patriotic Party (NPP) & $3,631,263$ & 43.10 \\
\hline & National Democratic Congress (NDC) & $2,750,124$ & \\
\hline & & & 52.45 \\
\hline 2004 & New Patriotic Party (NPP) & $4,524,074$ & 1.92 \\
\hline & National Democratic Congress (NDC) & $3,850,368$ & 1.00 \\
\hline & People's National Convention (PNC) & 165,375 & \\
\hline & Convention People's Party (CPP) & 85,968 & \\
\hline
\end{tabular}




\begin{tabular}{|c|c|c|c|}
\hline \multirow[t]{8}{*}{$2008\left(1^{\text {st }}\right.$ Round $)$} & New Patriotic Party (NPP) & $4,204,073$ & 49.32 \\
\hline & National Democratic Congress (NDC) & $4,070,889$ & 47.76 \\
\hline & Convention People's Party (CPP) & 112,673 & 1.32 \\
\hline & People's National Convention (PNC) & 73,618 & 0.86 \\
\hline & Democratic Freedom Party (DFP) & 28,471 & 0.33 \\
\hline & Independent Candidate & 19,178 & 0.22 \\
\hline & Democratic People's Party (DPP) & 8,367 & 0.10 \\
\hline & Reformed Patriotic Democrats (RPD) & 6,443 & 0.08 \\
\hline \multirow[t]{2}{*}{2008 ( $2^{\text {nd }}$ Round $)$} & National Democratic Congress (NDC) & $4,527,909$ & 50.47 \\
\hline & New Patriotic Party (NPP) & $4,443,654$ & 49.53 \\
\hline \multirow[t]{8}{*}{2012} & New Patriotic Party (NPP) & $5,573,572$ & 50.63 \\
\hline & National Democratic Congress (NDC) & $5,263,286$ & 47.81 \\
\hline & Progressive People's Party (PPP) & 64,267 & 0.58 \\
\hline & Great Consolidated Popular Party (GCPP) & 38,250 & 0.35 \\
\hline & People's National Convention (PNC) & 24,621 & 0.22 \\
\hline & Convention People's Party (CPP) & 20,109 & 0.18 \\
\hline & Independent Candidate & 15,156 & 0.14 \\
\hline & United Front Party (UFP) & 8,909 & 0.08 \\
\hline \multirow[t]{7}{*}{2016} & New Patriotic Party (NPP) & $5,755,758$ & 53.72 \\
\hline & National Democratic Congress (NDC) & $4,771,188$ & 44.53 \\
\hline & Progressive People's Party (PPP) & 106,092 & 0.99 \\
\hline & Convention People's Party (CPP) & 25,552 & 0.24 \\
\hline & People's National Convention (PNC) & 22,298 & 0.21 \\
\hline & National Democratic Party (NDP) & 16,935 & 0.16 \\
\hline & Independent Candidate & 15,911 & 0.15 \\
\hline
\end{tabular}

5.2 Parliamentary Election Results 1996 - 2016

\begin{tabular}{|l|l|r|r|}
\hline Year & Party & Seats Won & Percentage (\%) \\
\hline 1996 & National Democratic Congress (NDC) & 133 & 66.5 \\
\hline & New Patriotic Party (NPP) & 61 & 30.5 \\
\hline & People's Convention Party (PCP) & 5 & 2.5 \\
\hline & People's National Convention (PNC) & 1 & 0.5 \\
\hline & & & \\
\hline & New Patriotic Party (NPP) & 100 & 50.00 \\
\hline & National Democratic Congress (NDC) & 92 & 46.00 \\
\hline & Independent Candidates & 4 & 2.00 \\
\hline & People's National Convention (PNC) & 3 & 1.50 \\
\hline & Convention People's Party (CPP) & 1 & 0.50 \\
\hline & & & \\
\hline 2004 & New Patriotic Party (NPP) & 128 & 55.65 \\
\hline
\end{tabular}




\begin{tabular}{|l|l|r|r|}
\hline & National Democratic Congress (NDC) & 94 & 40.87 \\
\hline & People's National Convention (PNC) & 4 & 1.74 \\
\hline & Convention People's Party (CPP) & 3 & 1.30 \\
\hline & Independent Candidates & 1 & 0.43 \\
\hline & & & \\
\hline & National Democratic Congress (NDC) & 116 & 50.43 \\
\hline & New Patriotic Party (NPP) & 107 & 46.52 \\
\hline & Independent Candidates & 4 & 1.74 \\
\hline & People's National Convention (PNC) & 2 & 0.87 \\
\hline & People's Convention Party (PCP) & 1 & 0.43 \\
\hline & & 148 & 53.82 \\
\hline & National Democratic Congress (NDC) & 123 & 44.73 \\
\hline & New Patriotic Party (NPP) & 3 & 1.09 \\
\hline & Independent Candidates & 1 & 0.36 \\
\hline & People's National Convention (PNC) & & \\
\hline & & 169 & 61.45 \\
\hline & New Patriotic Party (NPP) & 106 & 38.55 \\
\hline
\end{tabular}

\subsection{STRATEGIC COORDINATION THEORY}

To address the questions raised above, I explore Cox’s $(1997,1999)$ coordination theory to analyze splitting in the Ghanaian general elections between 1996 and 2016. Cox $(1997,1999)$ developed a general theory of electoral coordination (especially elite-level coordination) which aimed at ensuring coordination within a single party (intraparty coordination) and coordination between and among parties (interparty coordination). Cox observed that electoral systems of any kind determine how votes are translated into seats and are replete with coordination problems for electoral competitors. Such problems emerge because there are more potential competitors than the available seats. Thus, within a single political party, there may be several contestants and within an ideological bloc, such as social democratic parties, there could be several capable candidates prepared and determined to enter the election fray in pursuit of fewer seats. This situation poses a coordination problem especially to the political parties involved in the sense that they will need to limit the number of competitors. Cox contends that this could be done by "either limiting the 
number of actual competitors (e.g. via joint lists or fusion candidacies), limiting the number of competitors for whom voters actually vote (strategic voting), or both. The process of limiting either entry or vote dispersion entails coordinating the actions of more than one person" (Cox 1999, 145146). The central thrust of Cox's general theory of electoral coordination goes as:

Electoral systems affect the coordination of political forces at two main levels: (a) within individual electoral districts when candidates and lists enter the electoral fray and voters distribute their votes among them; and (b) across these districts (within the nation as a whole) as potentially autonomous candidates and lists from different districts ally with one another to form regional or national parties. A third and final stage of coordination is less directly affected by electoral rules, namely the forming and sustaining of governments... district-level electoral coordination problems for the simplest electoral systems...two different $M+1$ rules apply. First, the number of candidates or lists entering a given race tends to be no more than $M+1$; second, when more than $M+1$ candidates or lists do enter a race, votes tend to concentrate on at most $M+1$ of them (Cox 1999, 160).

From the long quote above, Cox is making three important points. First, he meant that an

electoral system puts a ceiling on the viable number of competitors in an electoral district given by the $M+1$ rule. The $M$ denotes the district magnitude which tells us that if a constituency elects only one MP/candidate, then there is a tendency to have only two viable competitors in that constituency $(M+1)$ especially when a plurality formula is used to determine the outcome. If more than two candidates are contesting in such a constituency, then voters who want their votes to count, will concentrate their votes on the two most viable ones (vote strategically). How strategic voting may translate into ticket splitting is where a voter's choices in the different races are not for candidates from the same political party. Cox therefore, advices politicians to do their homework by way of coordinating on only $M+1$ candidates, so that voters will not have to vote strategically. The second form of elite coordination; political interaction across districts (constituencies), is what Cox refers to as linkage decisions among political actors (candidates and political parties contesting the election in different constituencies). It deals with the interaction between a presidential and a parliamentary candidates' joint efforts in executing an electoral campaign with 
the view that their supporters vote equally to both. The third phase of elite coordination has to do with political interaction for setting up and maintaining governments. Thus, it focuses on the distribution of offices (legislative and executive) to public officials. In sum, the first two phases are associated with elections and are directly affected by electoral rules whilst the third deals with formation and maintenance of governments.

In applying how the coordination problems identified by Cox can explain split-ticket voting, I will restrict the theory to the first two levels of coordination (but especially to the second level which deals with elite interactions) and use the third as a bargaining chip that top political actors can use to facilitate how they overcome the coordination problems they face. As political actors are interested in votes, policy, and office (Golder 2006, Kadima and Uteem 2006) it is easier for them to employ Cox's third-level of coordination (office and government formation) as a negotiation chip to address/overcome their coordination problems.

It worth pointing out that coordination problems faced by party elites and candidates are at times problems they deliberately create as they interact with other players in the pursuit of their political agenda. These problems are associated with certain identifiable indicators which are observed by Cox (1999), Benoit (2001), and Golder (2006). For the sake of clarity, I classify them into intraparty and interparty coordination successes and failures as doing so will give a clear gauge to assess how party elites (candidates and parties) behave in respect to the coordination problem they face. Coordination is necessary for party elites who are goal oriented and working together as a team in meeting those goals. Since they depend on one another to pursue a common goal, they will need to do things in a way that a single person pursuing similar goals will not normally do. Malone aptly captured this when he defined coordination as, "the additional information 
Samuel K. Darkwa

processing performed when multiple, connected actors pursue goals that a single actor pursuing the same goals would not perform" (Malone 1988, 5).

\subsubsection{Intraparty Coordination}

Intraparty coordination deals with how party elites negotiate their interdependent relations within a given political party. According to scholars such as Cox (1999), Benoit (2001), and Golder (2006), intraparty coordination has its associated observable indicators as shown in Table 5.3 below. When successful, the first observable indication is that political parties limit nomination or they coordinate on a single candidate (nominee). This is what Cox (1999) refers to as nomination control. He argues that nomination control could be done through primary elections or any internal party procedures that are transparent and democratic. Second, the consequence of nomination control is that the party runs fewer candidates. Where there is nomination control or fewer candidates are presented on a party's ticket, it is highly probable that some aspirants might withdraw their decision to contest or might lose to an in-party competitor.

Therefore, the third observable indication of a successful intraparty coordination is the ability of party elites to prevent losing or disappointed nomination seekers from entering the general election as independent candidates. This could be done by negotiating policy concessions and/or office positions with disappointed nomination seekers in exchange for their support prior to the elections. The promise of government position to losing in-party contestants may be enough to secure their support for the election. This is where Cox's third-level of coordination (government formation) becomes relevant in this chapter. The view is that government formation predates electoral victory and that it acts as a catalyst for inducing internal party cohesion for electoral success. The fourth observable indication of a successful intraparty coordination deals 
with linkage decisions among political actors from different districts within the same political party. This involves the creation of common or joint electoral platform between the presidential and legislative candidates of a given party. This may include the use of marketing strategies such as billboards and sponsoring joint adverts meant to make electoral impact. The presence of these in a party points to intraparty coordination success. Where there are intraparty coordination successes all things being equal, there will be straight-ticket voting, so we do not expect splitting.

Table 5.3: Observable Indicators of Intraparty Coordination Success and Failure

\begin{tabular}{|l|l|}
\hline Intraparty Coordination Success & Intraparty Coordination Failure \\
\hline Limiting nomination & Over nomination \\
\hline Running fewer candidates & Contentious primaries (independent contestants) \\
\hline Ability to prevent independents & Existence of splinter groups \\
\hline Creation of a joint platform & No policy linkage between candidates \\
\hline
\end{tabular}

Sources: Authors' own compilation from Benoit (2001), Cox (1999), and Golder (2006)

Contrary to the above are the indications of intraparty coordination failures as shown at the right quadrant of Table 5.3 above. The first signal of intraparty coordination failure is over nomination which happens where there exist factions, especially competitive and degenerative types (Boucek 2009, 479). Cox (1999) observed that Japan's Liberal Democratic Party (LDP) often had over nomination due to the existence of factions. In Ghana, the tendency of having about five independent parties from the Nkrumahist tradition contesting the election is a perfect example of intraparty coordination failure since their main ideological difference is a show of who is a true Nkrumahist (Jonah 1998, Osei 2012).

The second sign of unsuccessful intraparty coordination is undemocratic ways of conducting party's nomination process. Third, emanating from this is the inability of party elites to persuade disappointed nomination seekers from contesting the election as independent candidates. Normally, internal party competition is required for the bigger contest - the national 
or constituency contests (Crutzen et al.2009; Cox 1999) but when it leads to degenerative type referred to as race to the bottom (Boucek 2009; Crutzen et al.2009; Volden 2002), then mobilizing support for the bigger elections is bound to suffer. The fourth sign of intraparty coordination failure flows directly from the third, and it is the existence of splinter groups and defections from the party either to join another party or to create a new one. Analogous to this is fighting for supremacy among leading members of the party. The fifth failure is where there is a disconnect between the presidential and legislative candidates of a given party. Thus, the existence of parallel structures within a political party that produce duplication of campaigning of candidates, or the existence of animosity between the presidential and legislative candidates, are indications of intraparty coordination failures. Intraparty coordination failures are likely to produce ticket splitting, all things being equal. Based on these observations, I expect the following hypotheses as markers of intraparty coordination failures.

Where a party's nomination process is democratic, all things being equal, I expect both losers and winners to be gracious to each other and see the result as a victory to democracy and to the party. This is expected to unite the party towards the general elections and therefore, likely to reduce splitting. However, where a party's nomination process is tinted with accusations and counter accusations because the process is undemocratic, or someone chose to make it so, then I expect the aggrieved contestants to express their displeasure. If their concerns are not satisfactorily resolved, then ticket splitting is highly probable. These observations lead to the first hypothesis:

H1A: the more successful a party's nomination process is, the lower the likelihood of ticket splitting especially from party supporters.

Thus, higher incidence of successful party primaries is likely to be associated with lower levels of ticket splitting and vice versa. Consequently, all things being equal, I expect successful primaries and ticket splitting to be negatively related. When the party primaries become contentious, but 
party elites are able to resolve the issues, all things being equal, I expect the aggrieved nomination seekers to remain in the party and at best offer their support to the success of the party. However, where party elites are not able to resolve the concerns of aggrieved persons, such persons are more likely to threaten to leave the party or actually leave the party. Where aggrieved persons threaten to leave the party, all things being equal, it will affect party cohesion and if not properly handled, it is likely to produce ticket splitting. Thus,

$\mathrm{H} 1 \mathrm{~B}:$ the more unsuccessful party nomination seekers threaten to leave the party, the higher the chances of split-ticket voting.

Where aggrieved primary candidates' threats to leave the party are likely to induce ticket splitting if not handled well. The outcome may also depend on whether the threat to leave the party is credible or not. The status of such persons in the party will also affect how party elites respond to such threats. Hence, unresolved credible threats to leave the party which are not handled well are likely to produce splitting with the direction being positive while those that are handled well are expected to be negative all things being equal. Suffice it to say here that a threat to leave the party could be considered credible, if the person has the capacity to leave and draw others along or where the person actually leaves to contest as independent.

In fact, unresolved in-party conflicts from acrimonious parliamentary primaries are likely to produce skirt and blouse voting, especially where the aggrieved person(s) leave to contest as independent. Thus, where the party becomes fragmented because some aggrieved members are defecting to contest the elections as independent candidates, all things being equal, there will be high likelihood of ticket splitting. This leads to:

H1C: ticket splitting is likely to increase where unsuccessful nomination seekers in a party contest the elections as independent candidates. 
This often happens where in a particular constituency the aggrieved unsuccessful primary seekers decide to contest the parliamentary race as independent candidates. In such instances, persons who defect or contest the election as independents will advocate for ticket splitting and will like the party's candidate to lose even if that will mean another party's candidate winning the elections. Thus, the direction and the magnitude of a party member contesting the parliamentary election as independent candidate will be positively related to ticket splitting.

Finally, where there exist proper party linkages such that there is cordial rapport between the presidential and parliamentary candidates' campaign at the constituency level, especially where they rely on the party structures, ticket splitting is likely to be low. However, in instances where the presidential and parliamentary candidates' campaigns are disconnected, or they abandon the party structures in their campaigns, I expect to see more split-ticket voting. Hence,

H1D: the more harmonious the interaction between a presidential and legislative candidate of a party is, the lower the likelihood of ticket splitting.

Thus, where the candidates adopt common pool and conduct their campaigns in a harmonious manner, split-ticket voting is likely to reduce. I expect negative relationship between split-ticket voting and harmonious party relations such as the adoption of a joint platform between candidates.

\subsubsection{Interparty Coordination}

Interparty coordination (pre-electoral coalitions or electoral alliances) is any attempt by two or more political parties to harmonize their efforts jointly at the polls to maximize their mutual electoral benefits (Golder 2006). Interparty coordination is easier where two different parties with similar political ideologies forge electoral alliance (Golder 2006). However, unlike intraparty coordination that must be forged by political parties with same/similar ideology, interparty coordination could be forged by parties with different ideologies with the view of eliminating or 
defeating an "undesirable" party. Just like intraparty coordination success, interparty coordination success is marked by observable signals. Benoit (2001) observed that party elites through their coordination sent cues to voters who rightly responded to such signals. The first observable signal of a successful interparty coordination is that the parties involved do not contest the elections independently. This is done using joint nomination, running of joint lists, or fusing of candidates. The goal is to present fewer candidates and they do this by way of coordination. Second, related to the above, is strategic withdrawal of candidates. In some instances, parties that enter alliance negotiate on which candidates should step back. Benoit (20001) saw this as the strength of the Hungarian politicians in electoral coalition. Thus, the ability of parties to negotiate on step back arrangements points to signals of successful interparty coordination.

Third, parties in interparty alliances can negotiate and overcome the commitment problems faced by coalitions. Golder (2006) observed that due to the repeated interactions among preelectoral partners, the commitment problem in practice is very easy to resolve. In South Korea for instance, due to term limits, presidential pre-electoral alliances are easy to form. Fourth, partners in interparty alliances coordinate on their campaigns and ensure that they do run joint campaigns and coordinate all their marketing strategies. Fifth, the ability of coalition partners to secure the support of their members is key to successful interparty coordination (Benoit 2001; Cox 1999).

Interparty coordination failures are first characterized by over nomination. Cox (1999) argues that there will be coordination failure if an ideological bloc enters the electoral fray with all possible competent candidates contesting. Second, related to the preceding point is what Golder (2006) refers to as fight for supremacy. She observed that in France, members of the leadership group in the rightist party were fighting for leadership supremacy instead of fighting to defeat the leftist party. Third, conflict over policy, ideological differences and distributional problems are 
clear signs of interparty coordination failure. Golder (2006) found that distributional problems such as indivisibility of office impede pre-electoral coalitions in presidential systems especially in France. Although parties fail to form alliances due to policy and ideological divergence, Golder (2006) found that in France following the end of the Cold War, the center-left and center right parties do no longer have radical ideological differences as such they do not care much who wins. Thus, center-left parties for instance, run many candidates and do not make compromises such that in the 2002 presidential elections there were nine candidates representing the Left. The fourth sign of interparty coordination failure is the inability of coalition parties to secure the support of their members or support base (Benoit 20001; Golder 2006). Securing the support of coalition partners is crucial to the success of the coalition and this requires efficient and effective coordination. In fact, it is not enough to sign documents to enter electoral agreement to ensure the success of coalitions but rather the support of those whose votes are needed.

Table 5.4: Observable Indicators of Interparty Coordination Success and Failure

\begin{tabular}{|l|l|}
\hline Interparty Coordination Success & Interparty Coordination Failure \\
\hline Joint nomination/campaigns & Fight for supremacy \\
\hline Strategic withdrawal & Over nomination \\
\hline Effective negotiations & Conflict over policy/ideology \\
\hline Ability to secure members' support & Inability to secure members' support \\
\hline
\end{tabular}

Sources: Authors' own compilation from Benoit (2001), Cox (1997, 1999), and Golder (2006)

Flowing from the above discussions on interparty coordination, the chapter tests two hypotheses to falsify the credibility and reliability of the interparty coordination among coalition partners as far as Ghana is concerned. First, I expect that coalition partners will do their best to limit nomination by whatever best means they can which are anchored on transparent and democratic principles to ensure they put their best foot forward. That is, they coordinate on the most viable candidate(s) that can secure them the needed electoral victory or lead them in making 
electoral impact for future victory. Where the parties are able to coordinate on a single or required number of candidates, they need to endorse the coalition candidates and secure the support of their members. Thus, for a successful interparty coordination, party elites in alliance are expected to endorse coalition partners even those from another party who have been accepted as coalition candidates. Hence

H2A: the more party elites endorse candidates of other parties, the higher the likelihood of ticket splitting.

Thus, ticket splitting is expected to increase in such circumstances where parties do not necessarily contest the election as a coalition but agree to support other parties in areas and in races they do not contest. The direction of endorsement splitting is expected to be positive all things being equal. That is, the more party elites endorse other party's candidates, the higher the likelihood of splitting.

Emanating from the preceding paragraph is the issue of strategic withdrawal of candidates to facilitate the performance of another candidate or party's performance. As stated earlier, Cox (1999) argues that electoral coordination is necessary because there are more potential contestants than the available number of seats. Parties that do well are those that are able to coordinate on the most viable candidates. To be efficient in that requires some form of modality of agreeing on a viable or suitable candidate as discussed above. However, in the event that parties had already agreed on their candidates before the coalition or electoral arrangement, there will be the need for some parties to withdraw their candidates in certain constituencies or voting districts where their chances of winning are comparatively weak for those with better chances of winning to have even more promising chances. In fact, Benoit (2001) observed that in Hungary coordination also took the form of strategic withdrawal of candidates known as "stepping back" ostensibly to facilitate the chances of the contesting candidate. Consequently, the more such arrangements are done, the 
higher the likelihood of split-ticket voting given that party elites are able to secure the backing of their supporters. Therefore,

$\mathrm{H} 2 \mathrm{~B}$ : the more the widespread of strategic withdrawal of candidates, the higher the likelihood of ticket splitting.

Thus, I expect strategic withdrawal and ticket splitting to be positively related; that is the higher the instances of strategic withdrawal, the higher the likelihood of split-ticket voting and vice versa.

\subsection{ALTERNATIVE EXPLANATIONS}

Aside from the theory of strategic coordination and the accompanying hypotheses introduced above that evaluate my main argument about coordination induced ticket splitting, the chapter considers several alternate explanations used in the literature as they pertain to split-ticket voting. These include candidate quality, partisanship, restricted menu of choice, and education to ensure that alternative explanation to ticket splitting is not overlooked. Among these alternative explanatory variables, I expect candidate quality to be more connected to coordination because the essence of coordination is to settle on the most viable candidate or harmonizing a party's material and human resources to make the most of the current or future election.

\subsubsection{Candidate Quality}

The literature on candidate-level factors of ticket splitting has identified variables such as incumbency, campaign spending, and issue positioning as responsible for the phenomenon. In the United States, incumbents are said to often face unmatched contestants (Box-Steffensmeier 1996). As a result, party supporters whose preferred Congressional candidate is weak will vote for their presidential candidate and either roll-off or vote for a more experienced candidate who is often the 
incumbent (Born 1994; Burden and Kimball 2009). This is the case because incumbency is frequently associated with candidate quality (Benoit et al. 2006; Burden 2009; Scheiner, 2005).

Conversely, it has also been found that incumbency can also be a liability instead of being an asset (Burden 2009; Roscoe 2003; Scheiner 2005). Incumbents at times lose their party's primaries to in-party challengers and others lose the main contest to "unpopular" competitors. It has also been argued that the main cause of ticket splitting is campaign spending (Burden and Kimball 1998, 2009; Roscoe 2003). Thus, in the U.S. for instance, a candidate who is able to spend beyond $\$ 200,000$ has a greater chance of getting the attention of the electorate and therefore can cause ticket splitting (Burden and Kimball 1998, 2009; Roscoe 2003). It is also a common knowledge that some candidates often spend less than some incumbents and yet they win (Frempong 2017; Roscoe 2003). Given that incumbents do not always win, and high spending candidates lose to less spending competitors suggests that candidate quality works best with coordination.

The final candidate-level variable identified to be responsible for ticket splitting is issue positions. Proponents of issue positions argue that candidates can create ticket splitting by moving closer to their opponent's issue position or moving away from their party's position (Frymer 1994; Petrocik 1991; Petrocik and Doherty 1996). The line of this argument is elucidated by Key (1966) who argues that when there is a clear difference between the parties or candidates contesting the elections, voters can make distinct choices but where the contestants look alike on ideological grounds and issue positions, voters do not have unique choice, therefore, they will split their votes. Burden and Kimball (2009) found strong statistical association between candidate's issue position and ticket splitting. In a nutshell, the fundamental argument of proponents of candidate quality to ticket splitting is that, variations of candidate quality among contesting parties and or candidates 
can cause ticket splitting. This is where high-quality candidates in the different races are not from the same political party. Therefore, I expect higher variations in candidate quality among contesting parties to be associated with ticket splitting, all things being equal. Consequently,

$\mathrm{H} 3:$ where the most qualified (visible) candidates in the different races belong to different parties, the greater the likelihood of ticket-splitting

It worth pointing out however that, a party's ability to attract and field the most viable candidate boils down to the issue of coordination because where coordination fails, a party may fail to nominate the most qualified candidate or can have the most qualified candidate, but most splitters will likely split away from that candidate. However, with effective coordination, candidate quality is expected to be associated with positive splitting towards the most qualified candidate.

\subsubsection{Partisanship}

It has been found that, partisanship intensity is inversely related to split-ticket voting (Beck et al. 1992; Campbell et al. 1960; Campbell and Miller 1957). The argument made in support of partisanship and splitting is that persons who identify with parties will vote for their political parties irrespective of the candidate quality of their parties. These are often the core support base of a party. In contrast, Maddox and Nimmo (1981) found that all partisans split their ballots however, weak partisan do split more than other partisans. Thus, the position of Maddox and Nimmo (1981) gives clues that there are certain instances that even strong partisans may split their ticket. This chapter believes that one such context is where coordination problems faced by candidates and parties are not well handled. However, the conventional wisdom is that, weaker partisans are more likely to split their tickets. Consequently, I expect weak partisanship to be positively correlated with ticket splitting, all things being equal. Thus,

$\mathrm{H} 4:$ the weaker the partisan leaning of the electorates (in this case, party elites/card bearing members), the higher the chances of ticket splitting. 
It must be stressed however, that voter level factors for ticket splitting are different from elite level factors since normally elites will support and vote for all their candidates but will split their tickets when coordination breaks down.

\subsubsection{Restricted Choice}

Candidate availability has been identified as one of the candidate level factors of ticket splitting. It has been argued that two voters with diametrically opposing characteristics may have different choices. However, if for instance, no Republican (NPP or NDC in the case of Ghana) is running they cannot be able to vote for or against a Republican (NPP or NDC) candidate (Roscoe 2002). Benoit, Giannetti, and Laver (2006) refer to this situation as restricted choice menu. In their study of ticket-splitting in the Italian mixed member system, Benoit, Giannetti and Laver (2006) observed that though in mixed-member electoral systems voters are required to cast ballots simultaneously in single-member districts and multimember PR districts, yet because some parties do not have candidates in both constituencies, their supporters have to vote for different parties. They describe these voters as frustrated because they are forced to split their votes between their most preferred parties and others. This similar situation confronts the members and supporters of the smaller parties in Ghana who do not have candidates contesting all races in all constituencies. In my field work in Ghana where I surveyed party officials and members, about $26 \%$ out of 303 respondents cited the inability of their parties to have candidates in all constituencies as the motivation for voting skirt and blouse. If party officials who are supposed to think and act in party terms give such reasons as their motivation for voting skirt and blouse, then the electorates would not act differently when it comes to the effect of restricted choice menu on split ticket voting. Thus,

H5: as the proportion of constituency nominations covered by political parties decreases, the higher the likelihood of ticket-splitting. 
Samuel K. Darkwa

I expect a positive relationship between restricted choice and split-ticket voting, especially from the core supporters of smaller parties in instances where their parties contest in just one race in a concurrent presidential-legislative race.

\subsubsection{Education}

As discussed above, research has found correlation between education and ticket splitting (Beck et al., 1992; Dalton 2013; DeVries and Tarrance 1972). Some scholars have found positive association between education and ticket splitting; meaning higher educated voters are more likely to split their ticket than their lesser educated counterparts (De Vries \& Tarrance 1972). On the contrary, Campbell and Miller (1957) assert that lower level of education is associated with ticket splitting. As latter scholars have confirmed the positive relationship between higher levels of education and ticket splitting (Beck 1997; Beck et al., 1992; Dalton 2013), the chapter will expect positive correlation between education and ticket splitting. Therefore,

H6: the higher the level of education of the electorate, the higher the likelihood of ticket splitting.

Thus, the higher educated the respondent/voter is, the higher the likelihood of ticket splitting and vice versa. It worth stressing that often, where individual level factors are inferred from aggregate data it has a potential for ecological inference problems (Burden 2009; Burden and Kimball 2009; King 2013; King et al 2004; Roscoe 2003). However, such problems are not expected here because the data employed here is elite-level data used for elite-level analysis, thus, the chapter is not disaggregating elite voter behavior into individual voter behavior.

To sum up, based on the strategic coordination theory and the literature related to splitticket voting reviewed above, I expect the following: contentious primaries are most likely to be positively related to ticket splitting while successful primaries will be negatively associated to 
splitting. Instances where disappointed nomination seekers do threaten to leave the party or contest the election as independent candidates are likely to lead to ticket splitting. Therefore, situations where aggrieved members leave the party to contest as independents are likely to trigger ticket splitting. I also expect strategic withdrawals and endorsements to be positively related to splitting, especially in instances where parties and candidates who do the endorsement or the strategic withdrawal do not contest the election on the same party label/ticket but do so to facilitate the performance of one another. Additionally, weak partisanship and higher level of education are expected to be positively related to splitting. On the contrary, where there is harmony between the presidential and parliamentary candidates, I expect a negative relationship with ticket splitting.

\subsection{DATA AND MEASUREMENT}

The data for this chapter was based on fieldwork carried out in Ghana in 2017. The fieldwork sampled seven constituencies. In selecting the cases, the chapter considered how electoral scholars and analysts have divided the country based on the parties' strengths and the volatility of voter behavior in Ghana. The Ghanaian political terrain is dominated by the NPP and the NDC whose electoral performance together account for over 90\% of the votes since 1992 (Agyeman-Duah 2005, Frempong 2012, 2017, Lindberg 2013 Osei 2012). In the 2016 elections, for instance, there were six political parties and one independent candidate contesting the presidential slot. The outcome indicated that the NPP and NDC polled $98.3 \%$ against $1.7 \%$ for the rest of the contestants. Also, the 275 parliamentary seats were all won by the two major political parties (EC Ghana 2016; Frempong 2017).

Administratively, Ghana is divided into ten regions (six new regions were created in 2019 bringing the total number regions in the country to sixteen). These regions are further classified 
into Southern Ghana, Northern Ghana and the Middle Belt. Since the two major parties dominate the electoral landscape, electoral students and analysts have divided the ten administrative regions into how they relate to the two major parties. Four regions, Brong Ahafo, Central, Greater Accra, and the Western region are referred to as swing regions (Agyeman-Duah 2005; Frempong 2012, 2017, Lindberg 2013). The Ashanti in the middle belt and Eastern Region are the stronghold of the NPP while the three Northern Regions (Northern, Upper East and Upper West) as well as Volta Region are the stronghold of the NDC (Agyeman-Duah 2005; Frempong 2012, 2017).

With this background, to avoid the problem of selecting on the dependent variable, the selection of cases was based on the following criteria: 1) Constituencies that have and those that have not witnessed skirt and blouse outcomes; 2) Constituencies that experienced interparty electoral alliances; 3) Constituencies that are cosmopolitan; 4) Swing constituencies ${ }^{10}$; 5) Party strongholds; 6) Large population size (having more than 60,000 registered voters ${ }^{6}$ ); and 7) Constituencies won by a formerly party affiliated candidate who protested by going independent. These criteria were used to ensure that consideration is given to swing regions, party strongholds, north-south-middle belt concerns, as well as demographic and other peculiarities. Thus, the seven selected constituencies were identified based on how they fit into the criteria above. Listed in alphabetical order, they are Ablekuma South, Bantama, Ellembelle, Evalue Ajomoro Gwira, Ketu South, Klottey Korle ${ }^{7}$, and Wulensi. Out of the seven constituencies selected, four were from the Greater Accra and the Western Regions (that is two constituencies were selected from each of these two regions). In each case, the two constituencies selected from the Greater Accra and the Western Regions were contiguous. The selection was deliberately done to facilitate data collection and to save cost given that the selected constituencies satisfy all the criteria listed above. 
Alphabetically, the first constituency, Ablekuma South is in the Greater Accra Region (one of the swing regions). This constituency fits the criteria in many ways: first, it is a swing constituency, urban and cosmopolitan, and has large population density as shown by Table 5.5 below. Again, as shown by Table 5.6 below, in 1996 and 2008 the constituency witnessed skirt and blouse outcomes. In the 1996 general elections, the NDC won the presidential vote while the NPP won the parliamentary seat. Again, in 2008, the constituency witnessed skirt and blouse outcomes, but the two parties switched places in the sense that the NPP won the presidential race while the NDC took the parliamentary seat. The second constituency is Bantama in the Ashanti Region which is the stronghold of the NPP. Bantama is significant for its population density, unique voting pattern (voting about $80 \%$ straight-ticket), and ethnic dominance. It has never experienced a skirt and blouse outcome. Also, in the 2016 general elections, the incumbent parliamentary candidate of the NPP who had lost the party's primary filed to contest as independent candidate, but the party was able to dissuade him, and he withdrew from contesting as independent candidate. The third constituency is Ellembelle in the Western Region which has experienced three skirt and blouse outcomes (1996, 2000, and 2004). It is a constituency where the NPP never contested the parliamentary elections between 1996 and 2008 but supported the Table 5.5: Cases (constituencies) and their Fitness to the Selection Criteria

\begin{tabular}{|l|l|l|l|l|l|l|l|l|}
\hline & $\begin{array}{l}\text { Skirt \& } \\
\text { blouse } \\
\text { outcome } \\
\text { Constituency }\end{array}$ & $\begin{array}{l}\text { Experienced } \\
\text { Interparty } \\
\text { alliance }\end{array}$ & Cosmopolitan & $\begin{array}{l}\text { Swing } \\
\text { constituency }\end{array}$ & $\begin{array}{l}\text { Party } \\
\text { stronghold }\end{array}$ & $\begin{array}{l}\text { Huge } \\
\text { population } \\
\text { size } \\
+60,000 \\
\text { votes }\end{array}$ & $\begin{array}{l}\text { Won by } \\
\text { Independent } \\
\text { Protester }\end{array}$ & $\begin{array}{l}\text { Sample } \\
\text { size }\end{array}$ \\
\hline $\begin{array}{l}\text { Ablekuma } \\
\text { South }\end{array}$ & Yes & No & Yes & Yes & No & Yes & No & 37 \\
\hline Bantama & No & No & Yes & No & Yes & Yes & No & 51 \\
\hline Ellembelle & Yes & Yes & Yes & Yes & No & Yes & No & 39 \\
\hline $\begin{array}{l}\text { Evalue A. } \\
\text { Gwira }\end{array}$ & Yes & Yes & No & Yes & No & No & No & 39 \\
\hline Ketu South & No & No & No & No & Yes & Yes & No & Yo \\
\hline Klottey Korle & Yes & No & Yes & Yes & No & Yes & No & 38 \\
\hline Wulensi & Yes & No & No & Yes & No & No & Yes & 46 \\
\hline Others & & & & & & & & \\
\hline
\end{tabular}


$\mathrm{CPP}$ candidate to win the election for the three consecutive times. Interestingly, the CPP member for Ellembelle, Mr. Freddie Blay has left his party to join the NPP and is now the National Chairman of the NPP. Thus, Ellembelle constituency satisfies four out of the seven criteria as illustrated by Table 5.5 above.

The fourth constituency is Evalue Ajomoro Gwira also from the Western Region that adjoins the Ellembelle constituency. This constituency has witnessed a total of four skirt and blouse outcomes out of the six elections considered under this project. In general, Evalue Ajomoro Gwira has witnessed the highest number of skirt and blouse outcomes between 1996 and 2016. It fits the selection criteria in many ways. Though, with a smaller population size, the constituency has produced skirt and blouse outcomes between the two major parties (NPP-NDC) and has also produced a CPP/PCP (a smaller party) member of parliament through alliance with the NPP. The fifth constituency, Ketu South in the Volta Region, is a stronghold of the NDC often referred to as the NDC "world bank" (Agyeman-Duah 2005; Ayee 2014; Frempong 2012, 2017). Like Bantama, Ketu South is significant for its huge population density, unique voting pattern (voting about $90 \%$ for the NDC) and ethnic dominance. It has also never observed a skirt and blouse outcome. Albert Kwasi Zigah who was the NDC legislator for two terms between 2005 and 2012 lost his third term bid and contested the 2012 and 2016 elections as independent but lost in both attempts. Aside from Albert Kwasi Zigah, another NDC member and parliamentary aspirant, Mr. Jim Yao Morti, who was disqualified in the party's legislative primary in the constituency contested the election as independent in the 2016 election. Thus, two members of the NDC who were not nominated by the party ran as independents against NDC nominee in the 2016 election, but they both lost to the party's nominee. This shows how strong the party is at the constituency. The sixth constituency is Klottey Korle Constituency in the Greater Accra Region. This constituency has witnessed only 
one skirt and blouse outcome which occurred in the 2016 elections due to a protest from an NPP candidate who lost the party's primaries and decided to go independent. Per Table 5.5 above, the Klottey Korle Constituency satisfies four out of the seven criteria; it is a swing constituency (alternating between NPP and NDC. Also, the winner of this constituency wins the presidential slot), and a cosmopolitan with large population density.

Finally, Wulensi, the seventh constituency in the Northern Region is a swing constituency that has also witnessed three split outcomes (1996, 2004, and 2008). This constituency has voted for the ruling government, the opposition and independent candidates to get to parliament. It has also produced outcomes where the winning presidential candidates were from different parties at different times. Finally, it also marked an instance where a candidate who could not get the party's nomination in 2008 went independent and won the parliamentary seat.

Table 5.6: Selected Constituencies: Winning Candidates and Parties between 1996 and 2016

\begin{tabular}{|c|c|c|c|c|c|c|c|c|c|c|c|c|c|c|}
\hline \multirow[b]{2}{*}{ Constituencies } & \multirow[b]{2}{*}{ Region } & \multicolumn{2}{|c|}{2016} & \multicolumn{2}{|c|}{2012} & \multicolumn{2}{|c|}{2008} & \multicolumn{2}{|c|}{2004} & \multicolumn{2}{|c|}{2000} & \multicolumn{2}{|c|}{1996} & \multirow[b]{2}{*}{ Freq } \\
\hline & & Pres & Parl & Pres & Parl & Pres & Parl & Pres & Parl & Pres & Parl & Pres & Parl & \\
\hline $\begin{array}{l}\text { Ablekuma } \\
\text { South }\end{array}$ & $\begin{array}{l}\text { Greater } \\
\text { Accra }\end{array}$ & NDC & NDC & NDC & NDC & NPP & NDC & NPP & NPP & NPP & NPP & NDC & NPP & 2 \\
\hline Bantama & Ashanti & NPP & NPP & NPP & NPP & NPP & NPP & NPP & NPP & NPP & NPP & NPP & NPP & 0 \\
\hline Ellembelle & Western & NDC & NDC & NDC & NDC & NDC & NDC & NPP & CPP & NPP & CPP & NDC & CPP & 3 \\
\hline $\begin{array}{l}\text { Evalue A. } \\
\text { Gwira }\end{array}$ & Western & NDC & NPP & NDC & NDC & NPP & NPP & NPP & CPP & NPP & NDC & NPP & CPP & 4 \\
\hline Ketu South & Volta & NDC & NDC & NDC & NDC & NDC & NDC & NDC & NDC & NDC & NDC & NDC & NDC & 0 \\
\hline Klottey Korle & $\begin{array}{l}\text { Greater } \\
\text { Accra }\end{array}$ & NPP & NDC & NDC & NDC & NDC & NDC & NPP & NPP & NPP & NPP & NDC & NDC & 1 \\
\hline Wulensi & Northern & NPP & NPP & NDC & NDC & NPP & IND & NDC & NPP & NDC & NDC & NDC & NPP & 3 \\
\hline
\end{tabular}

Source: Author's compilation from Electoral Commission 1996-2016 (Skirt \& blouse outcomes colored; green represents two different parties while yellow represents a party and independent)

In respect of administering the surveys, I did part of the field work by myself and others were done by trained persons (professionals) whom I briefed on the goals of the research as well 
as the sampling frame. The research targeted the following: party chairs (either national, regional, district, or zonal), secretaries, women's organizers, youth leadership, campaign coordinators, treasurers, directors of elections, grassroots/cadres, research team members, results analysts, polling agents, and communication team members. Also sampled were eight MPs whose constituencies experienced split outcomes or were threatened with skirt and blouse voting. Further, 15 candidates defeated in their parties' primaries (of whom eight did not defect, one defector who was later dissuaded by his party to come back and six who contested the election as independent candidates) were interviewed. Also interviewed were five leaders of civil society organizations, one Deputy Chairman (Operations) of the National Commission for Civic Education, three faculty members at the Department of Political Science at the University of Ghana ${ }^{8}$ and nine media practitioners. In all, 303 respondents were surveyed through administered questionnaires (230 participants) and face-to-face interviews (73 participants) in March 2017. This was done to ensure that respondents fit the research questions. Details of the survey respondents and all the survey questions are in Chapter 3 Appendix 3.1. The coding of the variables is in Appendix 5.1,

\subsubsection{Dependent variable}

What this research sought to address is why a party elite or a card bearing member of a political party will vote skirt and blouse (split ticket). To establish this, respondents were asked in the survey question 26, "Have you ever voted skirt and blouse (that is to vote for presidential and parliamentary candidates in the same election from different political parties) before?" Thus, the dependent variable is skirt and blouse voting which is a dichotomous variable (a respondent voted skirt and blouse or not). I generated the dependent variable by coding respondents who answered "Yes" as " 1 " and "No" responses were coded as " 0 ". 


\subsubsection{Independent Variables}

The focus of this chapter is to empirically ascertain why Ghanaian party elites and party card bearing members will vote skirt and blouse or advocate for skirt and blouse voting (splitticket voting) a phenomenon which is uncommon in political science discourse/literature. This seems to show that Ghanaian voters behave in a manner inconsistent with ticket splitters in other parts of the world. I estimated logit model and discuss my coding rules below with summary provided at Appendix 5.1 below.

Successful Primaries: I compute successful primaries using Q5, “Please select the statement that most closely matches your view. In general, the recent parliamentary primaries of your political party were successful. "Strongly agree" and "moderately agree" were coded as " 1 " "Strongly disagree" and "moderately disagree" coded as "0". "Neutral/don't know" responses were treated as missing. I expect successful primaries to be negatively related to splitting.

Threaten to Leave Party: I measured the variable "Threaten to Leave Party" using Q6, "Did any defeated candidate of your party threaten to leave the political party?" "Yes" were coded as "1", "No" coded as " 0 " and "don't know" treated as missing. There were no "neutral" responses.

Go Independent: I generated the variable, "Go Independent" using Q9, "Did some losing parliamentary contestants go independent?" Respondents who answered "Yes" were coded as “1”, "No" coded as "0" and "Don't Know" treated as missing. There were no "neutral" responses.

Common Pool: The variable "Common Pool” was measured using Q17, "Leading to the elections did your party maintain a common pool of resources for both presidential and parliamentary campaigns?" Those who selected "Yes" were coded as "1", "No" coded as "0". There were no “don't know/neutral” responses. 
Samuel K. Darkwa

Endorsement: The variable "Endorsement" was generated using Q21, "Did your party endorse another candidate for either the presidential or parliamentary slot?" Respondents who answered "Yes" were coded as "1", "No" coded as "0" and "Don't Know" treated as missing. There were no "neutral" responses.

Candidate Quality: The variable "Candidate Quality” was generated using Q27 in respect of reasons given by respondents' decision for voting skirt and blouse. Respondents who chose candidate quality (which was the most popular response) were coded as " 1 " otherwise, coded as “0”. There were no “don’t know/neutral” responses.

\subsubsection{Control Variables}

Restricted Choice: I control for "Restricted Choice" using Q24 "Did your party contest in both presidential and parliamentary seats in all constituencies?" Respondents who selected "Yes" were coded as "1", "No" coded as "0" and "Don't Know" treated as missing. There were no "neutral" responses.

Party ID: The control variable, "Party Identification" variable (Party ID) was generated using Q3 “If you answered Yes, on Question 2, which political party is that?” Respondent's party affiliation was coded as per their responses; CPP 41, NDC 87, NPP 86, PNC 38, and PPP 44.

Education: I generated the education variable using the educational qualifications of respondents. In both models, education is on a seven rater-scale from " 0 " to "6" ranging from "Some Primary Schooling" to "University completed and beyond". Respondents who selected "I don't know" were treated as missing. 
Samuel K. Darkwa

\subsection{MODELING INTRAPARTY/INTERPARTY COORDINATION THEORY}

To understand the behavior of Ghanaian politicians and party elites in respect of their role in the facilitation of skirt and blouse voting, two factors need to be taken in to account. The first is the instances where the parties' nomination process is characterized by irregularities, especially, within the two dominant ones, NDC and NPP. The political parties in Ghana have ensured that as much as possible, they promote free, fair, and transparent internal competition. Against this backdrop, the NDC and the NPP have allowed the nations' Electoral Commission (EC) to supervise the elections of officials and candidates of their parties at all levels (Daddieh and BobMilliar 2012; Debrah 2014). Additionally, the parties have done their best to come out with single winners to contest the election on their respective party's ticket. They have also ensured that there is proper linkage between the presidential and the parliamentary candidates by resorting to the use of the party structures to conduct their campaigns (Debrah 2014; Osei 2012). The NDC and the NPP have always ensured that as much as possible, they prevent disappointed nomination seekers from contesting the elections as independent candidates even after acrimonious party primaries (Daddieh and Bob-Milliar 2012; Osei 2012). In most cases, these acts of intraparty coordination successes often ensure that the party wins both seats in a constituency. This notwithstanding, the parties have experienced serious setbacks in their intraparty coordination which is characterized by defections and inability of party elites to persuade some disappointed nomination seekers from entering the elections as independent candidates (Boafo-Arthur 2006, 2008; Daddieh and BobMilliar 2012; Debrah 2014; Frempong 2017; Osei 2012). Good examples of how disappointed nomination seekers going independent can cause split-ticket voting and consequently split outcome is the 2000 elections. In the 2000 general elections, there were four independent winners all of which unseated incumbent MPs who were seeking third term in the NDC. Each of the 
independent winners (Boniface Abubakar Saddique of Salaga constituency, Joseph Akudibillah of Garu -Tempane constituency, Rashid Bawa of Akan constituency, and James Victor Gbeho of Anlo, constituency) contested the election as independent candidates after unsuccessful primaries (Ayee 2002; Frempong 2017). Aside from the four independent winners, other candidates who went independent indeed caused the defeat of the NDC in six constituencies (Abetifi, Akropong, Akwatia, Ashaiman, Asutifi North, and Techiman South) (Ayee 2002; Frempong 2017).

The second factor is what I will refer to as the acts of "revisionist politicians" who will like to alter the political status quo in their parties by rocking the political boat or stirring controversy within the party or take advantage of a controversy and amidst the controversy leave the party to contest as independents (Ichino and Nathan 2013, 2017). The revisionist politicians are those who harbor presidential and parliamentary ambitions but know that if they were to play by the rules as prescribed by the status quo, they may not achieve their goals and therefore, must adopt unconventional strategies. Unlike a president who has a two-term limit, there is no term limit for a parliamentary candidate. So, an in-party competitor who wants to get to parliament but has a senior colleague in the same constituency who has been in parliament for more than two terms will begin to work against that member of parliament by either disputing the parliamentary primaries (Ichino and Nathan 2013, 2017) as undemocratic or advocate for skirt and blouse voting. The reason is that if the MP from his party loses, it will create an opportunity for him to achieve his goal (field interview March 2017) ${ }^{9}$. Again, those who harbor presidential ambitions also often use the party's structures to sabotage their presidential candidate (field interview March 2017). Though the president has a two-term limit, apart from former Presidents Rawlings and Mahama, all the other Presidents in Ghana's Fourth Republic made three attempts before winning. When they win they can seek reelection giving an individual about 20 years (three attempts at the presidency plus 
two possible terms making five multiplied by four years), in such cases, in-party competitors who cannot wait will advocate skirt and blouse voting and at times openly campaign against their party members which their out-party opponents will use against them (their party).

Between 1992 and 2008, it was not very likely for Ghanaian political parties to win the elections by counting on their individual strengths. For instance, in the 1992 elections, the NDC and other two political parties formed an alliance and made Mr. Rawlings, the NDC candidate their presidential candidate. Mr. K.N. Arkaah of NCP, a junior partner, was made the running mate while the alliance supported the parliamentary candidates of the other parties. In 1996, again, the NDC and two other parties formed the Progressive Alliance and helped the parliamentary slots of its junior partners. The NPP and PCP also formed the Great Alliance and made the PCP candidate its running mate and deferred some of the parliamentary seats for its alliance partner. In all instances, the junior parties deferred their presidential race to their senior partners, got the running mate and had their senior partners defer some of the parliamentary contests to them. Thus, the relationship between and among Ghanaian parties in alliance is such that the junior parties defer the presidential race to their senior partners and endorse their senior partners' presidential candidates and in return, their senior partners defer some of the parliamentary races, endorse and support their junior partners. Therefore, the interparty relations between and among Ghanaian parties in alliance is shaped to produce certain type of voting behavior among their supporters. It worth pointing out, however, that not all the party supporters were in favor of the kind of arrangements that their parties entered into with their alliance partners (Frempong 2017) because such arrangements required strategic withdrawals that denied their members the opportunity to contest in certain constituencies. Such persons in opposition to their party's arrangement with another at times call on their supporters to boycott the elections or vote against their parties. 
Therefore, understanding the nuances and intricacies of Ghanaian ticket splitting requires unraveling the contextual peculiarities and hurdles that the Ghanaian political elites and candidates faced within their parties and in negotiating with other parties for electoral purposes. Internally, the politician is faced with an in-party competitor whose presidential career requires a prospective presidential candidate a wait time of about twenty years while a parliamentary hopeful must wait in "perpetuity." The best possible means to overcome such hurdles is for the prospective candidate to adopt a revisionist approach by disputing the nomination process or calling on his supporters to vote skirt and blouse. When it comes to relations between and among parties in alliance, some candidates will have to withdraw and endorse their candidature of their alliance partners. In such instances some people must abandon their political dreams of winning elections at least for a period. In all these instances, aggrieved members who are unable to control their emotions or do not receive an assurance as an appropriate payoff for what they will have to forgo, will trigger certain indications of intraparty and interparty coordination failures which are likely to facilitate ticket splitting and eventual defeat of their in-party competitors. The intuition behind voter choice of party elites and aggrieved members under the strategic coordination theory operates on the assumption that they (the aggrieved members) will themselves vote against their parties and persuade their supporters to vote against at least one office of their party in a given constituency if the party fails to negotiate acceptable payoff. This payoff is often a promise of position in the new government if the party wins power.

\subsubsection{Results}

The chapter used the fieldwork datasets to run logit regression to examine the relationship between skirt and blouse voting and elite coordination. To confirm that the results are not compromised by missing data, multiple imputation techniques were employed to deal with missing 
data (StataCorp 2017). It appears most of the coefficients were not that significant as per Table 5.7 below. The results however, provide some empirical evidence in support of the strategic coordination induced ticket splitting especially in respect to conducting a successful primaries and elite endorsement. For instance, interparty coordination variable endorsement, (H2A) was significant and in the expected direction. The other interparty coordination variable, strategic withdrawal (H2B), however, was not significant. Among the intraparty coordination variables, successful primaries (H1A) and candidate quality (H3) were significant with the signs in the expected direction. Interestingly, the other intraparty coordination variables; threaten to leave party (H1B) and common pool (H1D) were not significant. Interestingly, the control variables party ID, restricted, and education were not that significant as per Model 1 in Table 5.7 below.

To ensure that missing data were not responsible for the results, multiple imputation techniques were employed to replace missing data, and the same binary logit regression used initially for Model 1 was used to run Model 2. The missing data per the coding above and in Appendix 5.1 below are made up of respondents who did not answer the questions used for the variables, as well as neutral, and “don't know” responses. The regression results from multiple imputation techniques displayed in Model 2 are essentially not different from those from Model 1 shown side by side in Table 5.7. In fact, endorsement (H2A) was equally significant as before and the sign in the expected direction. Successful primaries (H1A) too maintained its level of significance and in the expected direction. Candidate quality (H3) was also significant in both models. Interestingly party ID (H4) became the only significant control variable in the model after missing values were replaced through multiple imputation techniques. Finally, the McFadden's $\mathrm{R}^{2}$ of 0.608 computed from the model using fistat, lies above the conservative 0.2 and 0.4 range of 
McFadden's $\mathrm{R}^{2}$, it can be said with certainty that the model does well (McFadden 1974, 1977). That is, about 61 percent of the variance is explained by the model.

Table 5.7: Logit Analysis of 'Ticket-Splitting' using Survey Data

\begin{tabular}{|c|c|c|}
\hline VARIABLES & $\begin{array}{l}\text { With Missing Data } \\
\text { (Model 1) }\end{array}$ & $\begin{array}{l}\text { With Imputation } \\
\text { (Model 2) }\end{array}$ \\
\hline Successful Primaries (H1A) & $\begin{array}{c}-1.1983 * * \\
(0.5447)\end{array}$ & $\begin{array}{c}-1.5818 * * * \\
(0.3820)\end{array}$ \\
\hline Threaten to Leave Party (H1B) & $\begin{array}{c}0.5336 \\
(0.5767)\end{array}$ & $\begin{array}{c}0.0536 \\
(0.4360)\end{array}$ \\
\hline Go Independent (H1C) & $\begin{array}{l}-0.3447 \\
(0.5696)\end{array}$ & $\begin{array}{c}0.0144 \\
(0.4733)\end{array}$ \\
\hline Common Pool (H1D) & $\begin{array}{c}0.0699 \\
(0.5884)\end{array}$ & $\begin{array}{c}0.3393 \\
(0.4326)\end{array}$ \\
\hline Endorsement (H2A) & $\begin{array}{c}1.9797 * * * \\
(0.6796)\end{array}$ & $\begin{array}{c}0.1439 * * * \\
(0.4313)\end{array}$ \\
\hline Strategic Withdrawal (H2B) & $\begin{array}{c}0.4999 \\
(0.6910)\end{array}$ & $\begin{array}{c}0.3674 \\
(0.5970)\end{array}$ \\
\hline Restricted Choice (H5) & $\begin{array}{c}0.1105 \\
(0.5628)\end{array}$ & $\begin{array}{l}-0.0127 \\
(0.4430)\end{array}$ \\
\hline Party ID (H4) & $\begin{array}{c}0.2902 \\
(0.2038)\end{array}$ & $\begin{array}{c}0.2587 * * \\
(0.3726)\end{array}$ \\
\hline Candidate Quality (H3) & $\begin{array}{c}-4.3758 * * * \\
(0.5769)\end{array}$ & $\begin{array}{c}-3.2781 * * * \\
(0.5769)\end{array}$ \\
\hline Education (H6) & $\begin{array}{l}-0.1561 \\
(0.1061)\end{array}$ & $\begin{array}{l}-0.1105 \\
(0.0750)\end{array}$ \\
\hline Constant & $\begin{array}{l}-2.7129 \\
(1.8338)\end{array}$ & $\begin{array}{c}-2.1422 * * \\
(1.1217)\end{array}$ \\
\hline $\begin{array}{l}\text { Observations } \\
\text { McFadden's R }\end{array}$ & $\begin{array}{c}249 \\
0.608\end{array}$ & $\begin{array}{c}303 \\
\text { Note } 18\end{array}$ \\
\hline
\end{tabular}

I then computed changes in the probabilities of splitting by changing variables from their minimum to their maximum values and displayed the results in Table 5.8 below. The results show that when candidate quality was changed from its minimum to its maximum, the probability of splitting reduced by (0.446). This shows that ticket splitting can be induced by party elites when 
elite coordination results in situation where the most visible candidates are from different political parties. That is, the higher the disparities in candidate quality among the contesting parties, the higher the likelihood of splitting. It also shows that when party elites are able to field high quality candidates, they can reduce the chances of splitting by (.0446). When the variable endorsement was changed from its minimum to its maximum, the probability to split increased by (.070) meaning party elites can influence ticket splitting when they endorse candidates of other parties which is a common practice among parties that enter into electoral deals. In chapter 4, the variable was significant in four out of the six years under review. Finally, when the variable, successful primaries, was changed from its minimum to its maximum value, the probability of splitting reduced by (.023) meaning parties can reduce the likelihood of splitting when they conduct successful primaries.

Table 5.8: Effect of Changing Variables from Their Minimum to Maximum Values on Probability of Ticket Splitting

\begin{tabular}{|l|r|}
\hline Variables & $\begin{array}{r}\text { Probability } \\
\text { of Splitting }\end{array}$ \\
\hline Successful Primaries (H1A) & -0.023 \\
\hline Threaten to Leave Party (H1B) & 0.007 \\
\hline Go Independent (H1C) & -0.003 \\
\hline Common Pool (H1D) & 0.001 \\
\hline Endorsement (H2A) & 0.070 \\
\hline Strategic Withdrawal (H2B) & 0.007 \\
\hline Restricted Choice (H5) & 0.001 \\
\hline Party ID (H4) & 0.013 \\
\hline Candidate Quality (H3) & -0.446 \\
\hline Education (H6) & -0.017 \\
\hline
\end{tabular}

Note: Estimates are derived from Model 1 holding all other variables constant at their medians

\subsubsection{Discussion}

Per the results from the fitted logit regression above, coordination variables such as conducting successful primaries, endorsing candidates from another party and fielding candidates of high quality affect the chances of splitting in many significant ways. These are consistent with 
the theoretical expectation of the chapter. A couple of the variables, however, differed from expectations. In fact, research on coordination and voter behavior has found that coordination can be elite-driven through strategic entry (Arriola \& Arriola 2013; Benoit 2001; Cox 1999) or voterdriven through strategic voting (Conroy-Krutz 2013; Cox 1999). Therefore, coordination variables that were significant, such as conducting successful primaries and endorsement which were elite driven are not surprising. For instance, as of 1999, Cox had found that the decline in vote share suffered by Japan LDP's was the result of its inability to overcome coordination problems confronted it in the 1960s (Cox 1999). Similarly, Golder (2006) found that the French center-left parties were having as much as nine candidates contesting the 2002 presidential elections due to coordination problems. The fate of the Japan LDP and the French center-left parties are not different from those of the many smaller parties in Ghana that align with the first President of Ghana, Dr. Kwame Nkrumah who are not able to overcome their coordination problems that have led their parties reduced to a pale shadow of the original CPP which had won all the elections in Ghana between 1950s up to the mid-1960s. Sure, apart from parties that belong to the CPP who have been swept with the currents of coordination, in Ghana, the low and high tides of coordination can be seen when one considers the performance of the three main party traditions in the country today; the Nkrumahists (represented by the many fragmented parties that trace their origin to Nkrumah's principles) Danquah-Busia-Domo tradition (represented by the NPP) and the Akatamansonia (represented by the NDC) (Amponsah 2006; Apter 1966; Jonah 1998; Osei 2012). The significance level of the endorsement variable is supported by both published work on Ghana and my fieldwork. Together, they explain how elite endorsement has influenced skirt and blouse voting and hence, skirt and blouse outcome in Ghana. In the early 1990s, though Mr. Rawlings was very popular, the NDC's alliance with its coalition members helped secure the two 
successive electoral victories for the party and facilitated the winning of several parliamentary seats of its alliance members. Due to how the alliance was shaped, it led to ticket splitting because of how the NDC endorsed and supported the parliamentary candidates of its junior partners (in the same constituency, an NDC member was likely to vote NDC at the presidential race and for its alliance partner at the parliamentary race). The same was the case with the NPP and its alliance members. In fact, in the 1996 elections, the NPP and People's Convention Party (PCP) entered alliance and the PCP deferred its presidential slot to the NPP, endorsed and supported the NPP presidential candidate and in return, the NPP deferred some of the parliamentary races to the PCP. In the end, all the five seats the PCP won were in constituencies that the NPP deferred to, endorsed and supported the PCP (Agyeman-Duah 2005, Frempong 2017, Osei 2012). The NPP also could not have gotten the same presidential vote share without the PCP's support. In these instances, the results were all skirt and blouse outcome (split outcome) which is a strong indication that there were significant skirt and blouse voting. Again, in these instances, party elites and candidates openly encouraged skirt and blouse voting.

In fact, elites do it overtly and covertly but if you ask them, they will rather tell you their expected outcome of the election. It means that the focus is not on the means (skirt and blouse), but on the end (expected electoral outcome) and therefore, "the end justifies the means". One of my respondents said this about their alliance with the NPP,

"The Great Alliance (GA) was formed as an alliance between the NPP and the CPP/PCP to defeat the NDC. We had to forfeit our presidential race by making our flagbearer the running mate of the GA and endorse the NPP presidential candidate for the NPP to cede some parliamentary constituencies for the CPP/PCP. We further endorsed the NPP parliamentary candidates in constituencies we did not have candidates. The result of that alliance might be construed as skirt and blouse, but it was rather a mark of the success of the Great Alliance"10.

Endorsement, which is an interparty coordination mechanism, often takes place when there is an alliance and obviously, there will be compromises for the alliance to be successful. However, in 
Ghana, how the alliances have often been made normally produces split outcome because in the parliamentary race, the parties retain their original name and party labels (Ayee 1998; Frempong 2017; Ninsin 1998). Even in the presidential race, when the alliance adopts a different name, the government that is formed is considered the government of the major party that produced the presidential candidate (Ayee 1998; Frempong 2017; Ninsin 1998). For instance, in the 1992 election the NDC and two other parties formed alliance to win the election and the government was called the NDC government. Again, in 1996, the NDC and two other parties formed the Progressive alliance and that government was called the NDC government as well (Ayee 1998; Frempong 2017; Ninsin 1998). Thus, irrespective of the name of the alliance, official reports from the Electoral Commission and Parliamentary Hansard had always showed the registered names of the political parties (Electoral Commission 1992-2016; Ephson 2008, 2009, 2012, 2016). This also shows that the parties do not register the alliance names, neither do they contest with those names. They are instruments elites use to achieve their electoral objectives.

Though the interparty coordination has been successful as discussed in the preceding paragraph, it has been a sort of quagmire that has adversely affected parties in alliance and this could explain why the strategic withdrawal variable was not significant. There are published works to show this and it is supported by my fieldwork. One of my respondents revealed that alliance formation takes time, especially when you just come out from one that you got your fingers burnt. So, negotiations did not end before parliamentary candidates were elected and deciding on who should give up their nomination created conflict within the party and between members of the alliance. Below is the quote of respondent 5 on the subject:

"In 1992, we had just seven months to prepare for the election between the time the ban on political parties was lifted and the elections. Therefore, we rushed into an alliance with the NDC but before the next election, we had to leave that alliance and enter another. With the hindsight of the NDC experience, in 1996 we couldn't just rush into another one. It took 
time and we couldn't agree on the terms of the alliance before candidates were elected. Of course, that can't hold us from electing candidates. We operate by party constitution. So, withdrawal of candidates after the alliance became problematic and created conflicts within the individual parties and between the alliance parties"10.

Scholars such as Ayee (1997) and Frempong (2017) have substantiated how the inability to strategically withdraw candidates by the NPP-PCP alliance created problem for the parties. These scholars observed that in 1996 the Great Alliance (GA) between NPP and the PCP witnessed coordination problems where alliance candidates openly campaigned against each other. In some constituencies, for instance, the parties could not negotiate to withdraw some candidates because the NPP and PCP had already elected their candidates who had started campaigning. Consequently, in constituencies such as Ablekuma South, Awutu-Senya, Ayawaso Central, Okaikoi North, and Okaikoi South, candidates of the GA campaigned against each other (Ayee 1997, 425, Frempong 2017). These could explain why the strategic withdrawal variable was not significant in both models.

At the intraparty sphere, coordination problems, such as nomination problems discussed in section 5.2.1 above under discoveries from the fieldwork, could explain why the successful primaries variable was significant. From the fieldwork, it came to light among other things that some financiers support certain members of their rival parties to divide the votes in the recipient's party for the candidate of the financier's party to win. Furthermore, party elites who have presidential and parliamentary ambitions can sabotage the present holder of that position even if that person is from the ambitious contender's party. In certain instances, it could be a person in a position higher than the legislator who would undercut the legislator to lose the election for the superior authority to introduce his/her favorite. The result often creates skirt and blouse voting or skirt and blouse outcome. Respondent 4 said this about sabotage:

"...At times, if those at the top do not like you they will deliberately sabotage you. If for instance, they should give you materials they will give you lesser quantity or different type 
of materials which they know you cannot work with. This will go on till you lose the elections. ${ }^{17}$

Certainly, legislators do not work with "materials", but the message is obvious. That is, sabotage aims at undercutting the target person to fail at the end. Thus, the use of the word material in the analogy above should be read in context to mean the mechanism of sabotaging a target person.

Finally, unsuccessful primaries have robbed the two major parties, the NDC and the NPP, to lose the election in even their strongholds. The conflictual relationship that creates successful primaries often ensues between an incumbent MP and the challenger. In most cases either of them anticipates foul play from officials either due to sabotage or favoritism shown to either the incumbent or the challenger. When it happens, it is difficult to resolve because often the aggrieved person(s) does not trust the party officials. What follows is the aggrieved person contends the election as independent. Below is a quote from respondent:

"In 2012, the former NDC MP, Dr. Ato Quarshie, who had held the seat for three terms (1992, 1996 and 2000) staged a comeback to contest the parliamentary primaries of the NDC but lost the primaries by just 12 votes to the incumbent, Dr. Joseph Samuel Annan. Dr. Ato Quarshie was not happy with the results from the primaries but the party could not mediate the conflict between Dr. Joseph Samuel Annan and Dr. Ato Quarshie. At the end, Dr. Ato Quarshie contested as an independent and by so doing, divided the party's votes for the NPP's candidate, Stephen Nana Ato Arthur to win the seat with merely $38.17 \%$ of the votes whereas at the presidential slot, the NDC had won with 55.57\%.",

These evidence from the fieldwork aside, there are published documents that have shown how unresolved successful primaries have influenced aggrieved nomination seekers to contest the election as independents and either win or cause the defeat of their parties. In the 2000 election alone, the NDC lost four of its safe seats to aggrieved nomination seekers who contested as independents and defeated the incumbents seeking third term. Aside these four, others who went independents caused the defeat of six NDC incumbents (Boafo-Arthur 2008; Daddieh and Bob- 
Milliar 2012; Debrah 2014; Frempong 2017; Osei 2012). In all these instances, the results were skirt and blouse outcome pointing to significant skirt and blouse voting.

The above are some instances that Ghanaian political elites and candidates will openly advocate ticket splitting. Political elites' penchant of advocating ticket splitting is not unique to Ghana. In the U.S. for instance, during the 1996 elections, it was said that some Republican congressional candidates campaigned to be elected alongside President Clinton so that they could check him (Burden and Kimball 2009). Again, Senator Joseph Anthony Manchin (Joe Manchin) who has represented West Virginia since 2010 as Democrat is known for his liberal views and voting with Republicans on many policy issues. In fact, most people here on West Virginia University campus and within the United States that I discuss my research with had mentioned Senator Joe Manchin as a good example for skirt and blouse voting in the United States. During my fieldwork in Ghana, some of my respondents jokingly wanted to know if I received funding from Senator Joe Manchin when they found out I am schooling in West Virginia. Thus, political elites advocating for ticket splitting/skirt and blouse voting is something not entirely peculiar to Ghanaian elites and, therefore, research into such a phenomenon is in place.

\subsection{CONCLUSION}

In sum, this chapter attempts to address an unusual question in split-ticket voting by trying

to find out why party elites' coordination/interaction will influence ticket splitting or which candidates will split their ballot instead of the conventional question, "why some voters would split the ballot and others would not"? Again, it has also tried to make us understand how this elite behavior has affected the current distribution of votes and seats share of parties in Ghana. In addressing these questions, I carried out elite survey in Ghana in 2017 sampling 303 respondents comprising party elites and card bearing members of five Ghanaian political parties, members 
drawn from academia, the media and civil society. Though the sample was not randomly selected, it was selected to have a true representative of party officials from constituencies that have experienced skirt and blouse outcome and those that have not. It also sampled persons at the center of skirt and blouse voting (party officials advocating ticket splitting or threatened with it) and those who were not. I also needed to be circumspect in my interpretation because of the sample selection strategy. However, it is worth stressing that the regression results, the insights from the fieldwork, and published works by others on the subject support my interpretation and conclusions.

As evidenced by the results from the fitted binary logit regressions, the interparty coordination variable endorsement was significant in the models. Also significant was the core intraparty coordination variable, successful primaries which was significant in both models and having the signs in the expected direction. Candidate quality was also significant in both models. The significance of successful primaries, for instance, makes us aware that party elites are likely to split their ticket and advocate same where the party's nomination process is undemocratic. That is, in normal times, as long as the party's nomination process is transparent and democratic, we do not expect Ghanaian politicians and party elite to engage in ticket splitting or advocate that. However, in non-normal times where a politician calculates and finds that adhering to the status quo would mean that they wait in "perpetuity", they would like to accuse others of irregularities in the nomination process (Ichino and Nathan 2013, 2017) and use that excuse to get party officials to take decisions in their favor or leave with other supporters to contest as independent. Others who have parliamentary and presidential ambitions can sabotage their party candidates to lose the elections so that they can in future win a candidate that had lost on the party's ticket (Frempong 2017). In all these instances, these persons advocate skirt and blouse voting. In fact, leaving one's party and contesting as independent is not peculiar to Ghana ${ }^{10}$. In 2000 U.S. elections, former 
Republican Senator, James Jeffords of Vermont defected and contested as independent (Burden and Kimball 2009). It is likely that his defection will cause ticket splitting. It will be interesting to find out how he and his family and friends voted especially where after his defection he started fraternizing with Democrats.

At the interparty level, opinions are divided about the effects of coordination between bigger and smaller parties in Ghana which invariably have contributed to ticket splitting as in most instances, the smaller parties support the bigger parties in the presidential race and the bigger ones defer some parliamentary seats to the smaller parties. In fact, some respondents are of the view that it was largely because of interparty coordination that the smaller parties could pick the few seats in parliament in the past. However, in situations where the members of big parties have refused to coordinate with the smaller parties has led to what Mr. Kwesi Jonah refers to as "the withering away of the smaller parties" (field Interview March 13, 2017). To him, the country has lost the voice of the smaller parties. In a sharp contrast to this view, Dr. Ofori Mensah is of the view that the smaller parties have not articulated their own view since the inception of the $4^{\text {th }}$ Republican Parliament. To him, the smaller parties have always supported the bigger parties who supported them and as such have not presented their own platform (field Interview March 24, 2017). Thus, others think that though skirt and blouse voting and subsequently, skirt and blouse outcomes have helped the smaller parties to have representation in parliament because in few occasions that the smaller parties have gone into parliament it was due to interparty coordination, the relationship worked against the smaller parties. The reality is that in many instances, the bigger parties poach the viable candidates of the smaller parties and independent candidates by giving them ministerial appointments and other governmental appointments. These candidates have supported the policies of the government of the day and have not had their own voice. The 
observation by Yobo and Gyampo (2015) that the electoral performance of the minor parties within the Fourth Republic has dwindled and have been reduced to supporting the victory of the major ones is a worrying one. These parties need to augment their coordination game by coming together far ahead of time to give Ghana a viable alternative between the NDC and the NPP.

In sum, it is critical to carry out empirical research on how coordination problems affect parties, elites, and candidates. Such research will help party elites to identify and guard against intraparty coordination problems such as linkage problems which happen where there is no harmony between the parliamentary and presidential candidates' campaigns. Again, such research will help political parties to take steps to improve internal democracy if they know that imposition of a candidate on a constituency for instance, will cause skirt and blouse voting. We will also know that young politicians who have legislative ambition but are not able to realize such goal because their seniors already on the legislature have no term limit will make them adopt strategic coordination that may hurt their own parties. My field research shows that though politicians do not often overtly advocate ticket splitting, many do so when they see it to be in their interest and do so more at the grassroots. In fact, the nomination problems and deliberate sabotage discussed in sections 5.2.1 and 5.2.2 respectively show how politicians like DCEs/MCEs, party elites with presidential and parliamentary ambitions will undercut their own party members through skirt and blouse voting. Such conducts take place largely due to coordination problems that parties are unable to identify in the first place and address. Such a revelation will help politicians and crafters of constitutions to have a second look at ways of reviewing existing laws and policies to limit internal conflicts.

Ghana currently does not have a viable, major third party. The Nkrumahists who won independence for Ghana and formed the governments under the First and Third Republican 
Constitutions have now run out of steam due to the existence of several splinter groups which together attract less than two percent vote share. In fact, the 2016 elections results show that the two leading political parties pulled about 98 percent of the presidential votes cast and 100 percent of the legislative seats as per Table 5.1 and 5.2 (also see EC-Ghana 2016, Frempong 2017). This is due to coordination problems faced by the Nkrumahists elites. By such research, they can identify their coordination problems and craft proactive solutions for their coordination problems and workout pre-election coalition ahead of the 2020 elections. They can also figure out how to position themselves given that the Akatamansonia and the Danquah-Busia-Domo traditions occupy center-left and center-right respectively, the Nkrumahist who are the original leftist party can draw some votes from the left when they come together. Their coordination problem is not affecting that tradition alone, but Ghana's democracy given that there is policy vacuum at the far left and far right.

This chapter will suggest that further research into ticket splitting should also consider instances where party elites will strategically encourage split-ticket voting. Thus, questions such as why would parties, elites, and candidates encourage ticket splitting can advance our knowledge of the phenomenon. Another thing I chanced upon during my fieldwork, discussed under section 5.2.1, was how the financing of opposition election campaigns contributes to skirt and blouse voting. It was alleged that some politicians finance the campaigns of their opponents with the view that the recipients of such funds will find faults with their party's nomination process create confusion that will trigger observable indicators intraparty coordination failures discussed above. Such acts often divide the votes of the opponent's party and consequently, enhances the chances of the financier or his/her candidate to win the election. This invariably promotes ticket splitting in the recipient's part. It would therefore, be great to research into such acts in future. 


\subsection{REFERENCES}

Agyeman-Duah, Baffour. 2005. Elections and Electoral Politics in Ghana's Fourth Republic. Accra: Ghana Center for Democratic Development. No. 18.

Amponsah, Nicholas. 2006. "Political Traditions and Electoral Politics in Kintampo North and South, Sissala West and Wa Central." In Boafo-Arthur, Kwame (ed.): Voting for Democracy in Ghana: The 2004 Elections in Perspective. Vols. 1 \& 2. Accra: Freedom Publications, 287-307.

Apter, David. 1966. “Ghana”. In James Samuel Coleman, James Smoot Coleman, and Carl Gustav Rosberg (eds.) Political Parties and National Integration in Tropical Africa. Berkeley: University of California Press, 259-313.

Arriola, Leonardo R., and Leonardo Rafael Arriola. 2013. Multi-Ethnic Coalitions in Africa: Business Financing of Opposition Election Campaigns. Cambridge University Press.

Ayee, Joseph RA. 1997. "The December 1996 General Elections in Ghana.” Electoral Studies 16.3: 416-427.

Ayee, Joseph RA. 1998. "Election management and democratic consolidation: The Electoral Commission of Ghana" In Ayee, Joseph RA (ed.) The 1996 General Elections and Democratic Consolidation in Ghana. Department of Political Science University of Ghana.

Ayee, Joseph. 2002 "The 2000 General Elections and Presidential Run-Off in Ghana: An Overview." Democratization 9.2: 148-174.

Ayee, Joseph. 2014. "Assessing the progress of Democracy and Good Governance in Africa, the Ghanaian case." The Republic of Ghana.

Beck, Paul Allen, Lawrence Baum, Aage R. Clausen, and Charles E. Smith, Jr. 1992. "Patterns and Sources of Ticket Splitting in Subpresidential Voting." American Political Science Review 86:916-28.

Beck, Paul Allen. 1997. Party politics in America. Addison Wesley Publishing Company.

Benoit, Kenneth, Daniela Giannetti, and Michael Laver. 2006. "Voter Strategies with Restricted Choice Menus.” British Journal of Political Science 36.3: 459-485.

Benoit, Kenneth. 2001. "Two Step Forward, One Steps Back: Electoral Coordination in the Hungarian Elections of 1998." Typescript. Trinity College, Dublin.

Boafo-Arthur, K. (2006). "The 2004 General Elections: An Overview", In Boafo-Arthur, ed., Voting for Democracy in Ghana: The 2004 Elections in Perspective, Vol. 1. Accra: Freedom Publications, pp. 33-58.

Boafo-Arthur, Kwame. 2008. Democracy and Stability in West Africa: the Ghanaian Experience. Nordiska Afrikainstitutet; Department of Peace and Conflict Research, Uppsala University.

Born, Richard. 1994. "Split-ticket Voters, Divided Government, and Fiorina's Policy-Balancing Model.” Legislative Studies Quarterly. 95-115.

Boucek, Françoise. 2009. "Rethinking Factionalism: Typologies, Intra-Party Dynamics and Three Faces of factionalism.” Party Politics 15.4: 455-485. 
Box-Steffensmeier, Janet M. 1996. "A Dynamic Analysis of the Role of War Chests in Campaign Strategy." American Journal of Political Science. 352-371.

Burden, Barry C. 2009. "Candidate-Driven Ticket Splitting in the 2000 Japanese Elections.” Electoral Studies 28.1: 33-40.

Burden, Barry C., and David C. Kimball. 1998. "A New Approach to the Study of Ticket Splitting." American Political Science Review 92:533-44.

Burden, Barry C., and David C. Kimball. 2009. Why Americans Split their Tickets: Campaigns, Competition, and Divided Government. University of Michigan Press.

Campbell, Angus, and Warren E. Miller. 1957. "The motivational basis of straight and Split-Ticket Voting." American Political Science Review 51.2: 293-312.

Campbell, Angus, Philip E. Converse, Warren E. Miller, and E. Donald. 1960. The American Voter University of Chicago Press.

Conroy-Krutz, Jeffrey. 2013. "Information and ethnic politics in Africa." British Journal of Political Science 43.2: 345-373.

Cox, Gary W. 1997. Making Votes Count: Strategic Coordination in the World's Electoral Systems. Cambridge University Press.

Cox, Gary W. 1999. "Electoral rules and electoral coordination." Annual Review of Political Science 2.1: 145-161.

Crutzen, Benoit SY, Micael Castanheira, and Nicolas Sahuguet. 2009. "Party organization and electoral competition." The Journal of Law, Economics, \& Organization 26.2: 212-242.

Daddieh, Cyril K., and George M. Bob-Milliar. 2012. "In Search of 'Honorable' Membership: Parliamentary Primaries and Candidate Selection in Ghana." Journal of Asian and African Studies 47.2: 204-220.

Daddieh, Cyril. 2011. "Democratic Consolidation Without a Second Turnover: Ghana's Remarkable 2004 Elections." In Abdoulaye Saine, Boubacar N'Diaye, and Mathurin Houngnikpo (eds.) Elections and Democratization in West Africa 1990-2009. Trenton, New Jersey: Africa World Press.

Dadzie, Ato Kwamena. 2008. "Let's vote 'skirt and blouse", Ghanaweb.com Retrieved on July 8, 2019, from https://www.ghanaweb.com/GhanaHomePage/features/Let-s-vote-skirt-and-blouse$\underline{154036}$

Dalton, Russell J. 2013. The Apartisan American: Dealignment and Changing Electoral Politics. CQ Press.

De Vries, Walter, and V. Lance Tarrance. 1972. The Ticket-Splitter: A New Force in American Politics. Grand Rapids: Eerdmans.

Debrah, Emmanuel. 2014. "Intra-Party Democracy in Ghana's Fourth Republic: The Case of the New Patriotic Party and National Democratic Congress." Journal of Power, Politics \& Governance 2.3: 57-75. 
Duverger, Maurice. 1954. Political Parties: Their Organization and Activity in The Modern State. London: Methuen.

EC-Ghana. 2016. "The 2016 Presidential Results - Electoral Commission Ghana." Retrieved September 20, 2018, from http://www.thumbsapp.com.gh/

Electoral Commission, Ghana. Parliamentary and Presidential Election Results. 1996, 2000, 2004, 2008, 2012, 2016.

Ephson Ben 2012. “The 2012 Elections.” Accra: Allied News Limited

Ephson Ben 2016. “The 2016 Elections.” Accra: Allied News Limited.

Ephson, Ben. 2009 "Ben Ephson on the 2008 Elections." Accra: Media Graphics and Press Ltd.

Ephson, Ben. 2008. The countdown to 2008 Elections. Allied News.

Frempong, Alexander Kaakyire Duku. 2012. Electoral Politics in Ghana's Fourth Republic: In the Context of Post-Cold War Africa. Accra: Freedom Publication.

Frempong, Alexander Kaakyire Duku. 2017. Elections in Ghana: 1951 - 2016. Digibooks Ghana Ltd.

Frymer, Paul. 1994. “Ideological Consensus Within Divided Party Government.” Political Science Quarterly 109.2: 287-311.

Golder, Sona Nadenichek. 2006. The Logic of Pre-Electoral Coalition Formation. Ohio State University Press.

Ichino, Nahomi, and Noah L. Nathan. 2013. "Do Primaries Improve Electoral Performance? Clientelism and Intra-Party Conflict in Ghana." American Journal of Political Science 57.2: 428441.

Ichino, Nahomi, and Noah L. Nathan. 2017. "Primary Elections in New Democracies: The Evolution of Candidate Selection Methods in Ghana."

Jonah, Kwesi. 1998. "Political Parties and the Transition to Multi-Party Politics in Ghana." Ghana. Transition to Democracy, Accra: Freedom Publications: 72-94.

Kadima, Denis, and Cassam Uteem. 2006. The Politics of Party Coalitions in Africa. EISA.

Key, Valdimer Orlando, and Milton Curtis Cummings. 1966. The Responsible Electorate: Rationality in Presidential Voting, 1936-1960, [by] VO Key, with the Assistance of Milton C. Cummings; Foreword by Arthur Maass. Harvard University Press.

King, Gary, Martin A. Tanner, and Ori Rosen. 2004. Ecological Inference: New Methodological Strategies. Cambridge University Press.

King, Gary. 2013. A Solution to the Ecological Inference Problem: Reconstructing Individual Behavior from Aggregate Data. Princeton University Press. 
Lartey-Adjei Festus. 2012. "Be Bold; vote skirt and blouse!" Ghanaweb.com Retrieved on July 8, 2019, from https://www.ghanaweb.com/GhanaHomePage/NewsArchive/Be-Bold-vote-skirt-andblouse-Sakara-258747

Lindberg, Staffan I. 2013. "Have the Cake and Eat It: The Rational Voter in Africa." Party Politics 19.6: $945-961$.

Maddox, William S., and Dan Nimmo. 1981. "In Search of the Ticket Splitter." Social Science Quarterly 62.3: 401.

Malone, Thomas W. 1988. "What is coordination theory?" Paper presented at the National Science Foundation Coordination Theory Workshop. Massachusetts Institute of Technology Cambridge, Massachusetts.

McFadden, Daniel. 1974. "Frontiers in Econometrics, chapter Conditional logit analysis of qualitative choice behavior."

McFadden, Daniel. 1977. Quantitative Methods for Analyzing Travel Behavior of Individuals: Some Recent Developments. Berkeley: Institute of Transportation Studies, University of California.

Navia, Patricio, and José Luis Saldaña. 2015. "Mis-Coordination and Political Misalignments in Ticket-Splitting: The Case of Chile, 2005-2009. “Contemporary Politics 21.4: 485-503.

Ninsin, Kwame Akon. 1998. "Postscript: Elections, Democracy and Elite Consensus". In Kwame Akon Ninsin (ed.) Ghana: Transition to democracy. African Books Collective, 1998.

Osei, Anja. 2012. Party-Voter Linkage in Africa: Ghana and Senegal in Comparative Perspective. Springer Science \& Business Media.

Petrocik, John R. 1991 "Divided Government: Is it All in the Campaigns?" The Politics of Divided Government: 13-38.

Petrocik, John R., and Joseph Doherty. 1996. "The Road to Divided Government: Paved without Intention." In Peter F. Galderisi (ed.) Divided Government: Change, Uncertainty, and the Constitutional Order. Lanham, MD: Rowman and Littlefield.

Roscoe, Douglas D. 2003. "The Choosers or the Choices? Voter Characteristics and the Structure of Electoral Competition as Explanations for Ticket Splitting." Journal of Politics 65.4: 11471164.

Scheiner, Ethan, 2005. Democracy with Competition in Japan: Opposition Failure in a One-Party Dominant State. Cambridge University Press, New York.

StataCorp, L. P. 2017. “Stata Multiple-Imputation Reference Manual Release 15.” Texas: Stata Press

Volden, Craig. 2002. "The Politics of Competitive Federalism: A Race to the Bottom in Welfare Benefits?" American Journal of Political Science: 352-363.

Yobo, Eric, and Ransford Edward Van Gyampo. 2015. "Third Parties and Electoral Politics in Ghana's Fourth Republic.” J. Pol. \& L.8: 7. 


\subsection{NOTES}

1. https://www.ghanaweb.com/GhanaHomePage/NewsArchive/Be-Bold-vote-skirt-and-blouse$\underline{\text { Sakara-258747 }}$

2. https://www.ghanaweb.com/GhanaHomePage/features/Let-s-vote-skirt-and-blouse-154036

3. Largely, political actors send cues to guide voter choice. In most cases, they want them to behave as we would often expect (coordination/straight tickets). However, voters do not always behave as politicians expect them to.

4. I use the term 'interparty coordination' to characterize any form of pre-electoral interactions and/or arrangement between parties, candidates and individual deals between them capable of affecting their electoral performance. It also encompasses their negotiations for policy and office prior to the elections.

5. Interview with a Policy Analyst of the main opposition NDC and with the Achimota Zonal Chairperson of the ruling NPP on Wednesday, March 8, 2017 by author.

6. Interview with NDC parliamentary candidate who was a victim of skirt and blouse advocacy at the Parliament House on Wednesday, March 8, 2017 by author and with NPP Western Regional Chairperson on Tuesday, March 14, 2017 by enumerator.

7. Interview with a faculty at the Political Science Department at the University of Ghana (Legon) on Wednesday, March 15, 2017 by author.

8. Interview with the Deputy Director of Operations, National Commission for Civic Education (NCCE) Ghana and with an NDC parliamentary candidate who was a victim of skirt and blouse advocacy, at the Parliament House on Wednesday, March 8, 2017 by author.

9. Interview with the Deputy Director of Operations, National Commission for Civic Education (NCCE) Ghana on Wednesday, March 8, 2017 and with the Director of Research to the main opposition NDC on Wednesday, March 15, 2017 by author.

10. Interview with the Second National Chairperson of the Convention People's Party on Friday, March 10, 2017 by author.

11. Interview with the Second National Chairperson of the Convention People's Party on Friday, March 10, 2017 and with a National Civic Society leader on Monday, March 13, 2017 by author.

12. The swing constituencies are erratic in their voting patterns and any political party that wins the swing regions wins the national elections since 1992. 
13. Constituency with more than 60,000 registered voters is considered large because it exceeds the national average of about 56,000 registered voters and about 39,000 valid votes cast as per the 2016 electoral statistics.

\section{Klottey Korle constituency is at times written Korle Klottey or Osu Klottey.}

15. One of the faculty from the Department of Political Science in the University of Ghana interviewed is the author of Elections in Ghana 1951 - 2016 whom I quoted copiously in this chapter. The next has also written extensively on elections. He was a former head of the department and has headed the governance centers of two think tanks. He is currently the head of the governance center of The Institute for Democratic Governance (IDEG) in Ghana. The third wanted to remain anonymous. I also received a great deal of support from the immediate past head of the political science department who is now the Deputy Commissioner at the EC. He introduced me to the president of the Political Science Students Association at the University of Ghana.

16. This situation is not unique to Ghana however, it has become an issue such that if an MP spends more than two terms in parliament, that member becomes a target within his/her party. In fact, one of the MPs I interviewed during my fieldwork (Hon. Alhassan Fuseini Inusah), who had been threatened with skirt and blouse voting in the 2016 election on his fourth attempt hinted he was not going to stand for reelection. I am not surprised he has confirmed that decision (retrieved on January 8, 2019, from https://www.myjoyonline.com/politics/2018/July-3rd/inusah-fuseini-bowsout-of-2020-parliamentary-race.php)

17. Interview with a cadre of the opposition National Democratic Congress on Thursday, March 9, 2019 in Accra.

18. Standard measure of fit cannot be calculated for multiple imputation technique model. Per Stata Multiple-Imputation Reference Manual Release 15, standard measure of fit does not work with models estimated using multiple-Imputation technique.

Appendix 5.1: Coding at the Elite Level of Analysis

\begin{tabular}{|c|c|c|}
\hline Variable & $\begin{array}{l}\text { Description of the Variable (questions in } 2017 \\
\text { field Survey) }\end{array}$ & Coding Rule \\
\hline Split (DV) & $\begin{array}{l}\text { To measure the DV, respondents were asked in Q26, } \\
\text { "Have you ever voted skirt and blouse (that is to vote } \\
\text { for presidential and parliamentary candidates in the } \\
\text { same election from different political parties) } \\
\text { before?" }\end{array}$ & $\begin{array}{l}\text { Respondents who answered "Yes" } \\
\text { were coded as " } 1 \text { " and "No" coded as } \\
\text { "0" }\end{array}$ \\
\hline $\begin{array}{l}\text { Successful } \\
\text { Primaries }\end{array}$ & $\begin{array}{l}\text { I compute successful primaries using Q 5, "Please } \\
\text { select the statement that most closely matches your } \\
\text { view. In general, the recent parliamentary primaries } \\
\text { of your political party were successful". }\end{array}$ & $\begin{array}{l}\text { "Strongly agree" and "moderately } \\
\text { agree" coded as "1", "strongly } \\
\text { disagree" and "moderately disagree" } \\
\text { coded as " } 0 " \text { ", "neutral / don't know" } \\
\text { treated as missing. }\end{array}$ \\
\hline $\begin{array}{l}\text { Threaten to } \\
\text { Leave Party }\end{array}$ & $\begin{array}{l}\text { Threaten to Leave Party was measured using Q6, } \\
\text { "Did any defeated candidate of your party threaten to } \\
\text { leave the political party?". }\end{array}$ & $\begin{array}{l}\text { "Yes" coded as "1", "No" coded as "0" } \\
\text { and "don't know" treated as missing. }\end{array}$ \\
\hline
\end{tabular}


Samuel K. Darkwa

\begin{tabular}{|c|c|c|}
\hline $\begin{array}{l}\text { Go } \\
\text { Independent }\end{array}$ & $\begin{array}{l}\text { I generated the variable, 'Go Independent' using Q9, } \\
\text { "Did some losing parliamentary contestants go } \\
\text { independent?" }\end{array}$ & $\begin{array}{l}\text { "Yes" coded as " } 1 ", \text { "No" coded as "0" } \\
\text { and "don't know" treated as missing. }\end{array}$ \\
\hline $\begin{array}{l}\text { Common } \\
\text { Pool }\end{array}$ & $\begin{array}{l}\text { The variable "Common Pool" was measured using } \\
\text { Q17, "Leading to the elections did your party } \\
\text { maintain a common pool of resources for both } \\
\text { presidential and parliamentary campaigns?" }\end{array}$ & $\begin{array}{l}\text { "Yes" coded as " } 1 \text { ", "No" coded as } \\
\text { "0". }\end{array}$ \\
\hline Endorsement & $\begin{array}{l}\text { The variable "Endorsement" was generated using } \\
\text { Q21, "Did your party endorse another candidate for } \\
\text { either the presidential or parliamentary slot?" }\end{array}$ & $\begin{array}{l}\text { "Yes" coded as "1", "No" coded as "0" } \\
\text { and "don't know" treated as missing. }\end{array}$ \\
\hline $\begin{array}{l}\text { Strategic } \\
\text { Withdrawal }\end{array}$ & $\begin{array}{l}\text { I generate the variable, "Strategic Withdrawal" using } \\
\text { Q23, "Did your party decide to leave out any } \\
\text { constituency or withdraw a candidate from a } \\
\text { particular constituency to help another party win that } \\
\text { seat?" }\end{array}$ & $\begin{array}{l}\text { "Yes" coded as " } 1 ", \text { "No" coded as "0" } \\
\text { and "don't know" treated as missing. }\end{array}$ \\
\hline $\begin{array}{l}\text { Restricted } \\
\text { Choice }\end{array}$ & $\begin{array}{l}\text { The variable "Contest both Offices" was generated } \\
\text { using Q24 "Did your party contest in both } \\
\text { presidential and parliamentary seats in all } \\
\text { constituencies?" }\end{array}$ & $\begin{array}{l}\text { "Yes" coded as "1", "No" coded as "0" } \\
\text { and "don't know" treated as missing. }\end{array}$ \\
\hline Party ID & $\begin{array}{l}\text { It was generated using Q3 "If you answered Yes, on } \\
\text { Question 2, which political party is that?" }\end{array}$ & $\begin{array}{l}\text { Respondent's party affiliation was } \\
\text { coded as per their responses; CPP 41, } \\
\text { NDC 87, NPP 86, PNC 38, and PPP } \\
44 .\end{array}$ \\
\hline $\begin{array}{l}\text { Candidate } \\
\text { Quality }\end{array}$ & $\begin{array}{l}\text { The variable "Candidate Quality" was generated } \\
\text { using Q27 Why? which was a follow-up to Q26 } \\
\text { "Have you ever voted skirt and blouse (that is to vote } \\
\text { for presidential and parliamentary candidates in the } \\
\text { same election from different political parties) } \\
\text { before?" }\end{array}$ & $\begin{array}{l}\text { Respondents who chose candidate } \\
\text { quality (which was the most popular } \\
\text { response) were coded as " } 1 \text { " otherwise, } \\
\text { coded as " } 0 \text { ". }\end{array}$ \\
\hline Education & $\begin{array}{l}\text { I control for education using the educational } \\
\text { qualification of respondents. }\end{array}$ & $\begin{array}{l}\text { Education is on a seven rater-scale } \\
\text { from "0" to "6" (some primary } \\
\text { schooling to "university completed \& } \\
\text { beyond). Respondents who selected "I } \\
\text { don't know" were treated as missing }\end{array}$ \\
\hline
\end{tabular}




\section{CHAPTER 6. CONCLUSION}

\subsection{FINDINGS FROM THE RESEARCH}

In this dissertation, I have attempted to examine how voter-level and elite-level factors can enhance our knowledge of ticket splitting in an emerging democracy like Ghana. In doing so, the dissertation employed Cox's $(1997,1999)$ strategic coordination which posits that strategic voting by the electorate is due to unresolved elite coordination problems. That is, voters in pure SMDs for instance, will coordinate their votes on the top two candidates when elites fail to coordinate their entry on only two viable candidates. This can translate into splitting when elite coordination creates incentives for voters to vote strategically and the candidates a voter selects in different races are not from the same party. The analysis carried out here has been approached at three levels. These are: individual-level, constituency-level, and elite-level using different datasets appropriate for each level to examine the phenomenon. This approach has helped to improve our knowledge on ticket splitting, elite behavior, and Ghanaian electoral politics.

First, analysis at the individual level considered the characteristics of voters alongside variables indicative of voter and elite coordination. I conducted this evaluation to determine which variables best explain split-ticket voting. Interestingly, the individual level variables perform poorly. In fact, the demographic and socioeconomic variables were weak and inconsistent as in other findings (Burden and Kimball 1998, 2009; Bybee et al. 1981; Campbell and Miller 1957; Roscoe 2003). It was only income that was partly significant just in one out of the six models run in chapter 3. By contrast, the political information variables: radio, television and newspaper present interesting findings. First, radio exposure for instance, is negatively related to splitting, indicating that voters might be listening to radio networks that match their political inclinations as 
found by scholars such as (Burden and Kimball 1998, 2009; Roscoe 2003). Newspaper and television were partly significant. Put together, the effects of political information are largely inconsistent as found by many scholars (Atwood and Sanders 1975; Beck et al. 1992; Burden and Kimball 1998, 2009; Bybee et al. 1981; Campbell and Miller 1957; Roscoe 2003). Their inconsistency with splitting is indicative of the fact that they can be tools for whipping voter decision in certain direction during elections (Chandra 2007, 2009; Mclaughlin 2008).

Elite coordination variables such as party positioning and parliamentary split were highly significant when used alongside the voter level variables discussed in the preceding paragraph. In chapters three and five, I showed that when party elites distance themselves from their party's policy or position themselves closer to their opponent's policies, they create ticket splitting. This explains why perceived party similarities (candidate positioning) variable was significant. Again, some party supporters and elites often withdraw from their PCs due to coordination problems and that is a huge cause of skirt and blouse voting in Ghana. It was not surprising that the parliamentary split variable was highly significant in all the models in Chapter 3 and the signs in the expected direction. Certainly, comparing the performance of elite level factors against voter level factors from the regression results demonstrates that differences in ticket splitting are better explained by variation in the degree of elite coordination than by variation in characteristics of individual voters such as political sophistication, demographic and socioeconomic variables. In fact, ticket splitting has largely been influenced by changes in elite coordination. The relationship between elite coordination and ticket splitting is depicted by Figure 6.1 below (constructed from Table 4.7 in chapter 4), which shows the relation between disputed constituencies in parliamentary elections and split outcomes in Ghana between 1996 and 2016. Disputed primaries in parliamentary elections which is a major elite coordination pitfall discussed in chapter 4, to greater extent, seems 
to be an important contributor to split outcomes because almost every constituency that had disputed primaries in parliamentary elections experienced split outcomes.

Figure 6.1: Percentage of Split Constituencies vs. Parliamentary Disputed Primaries 19962016

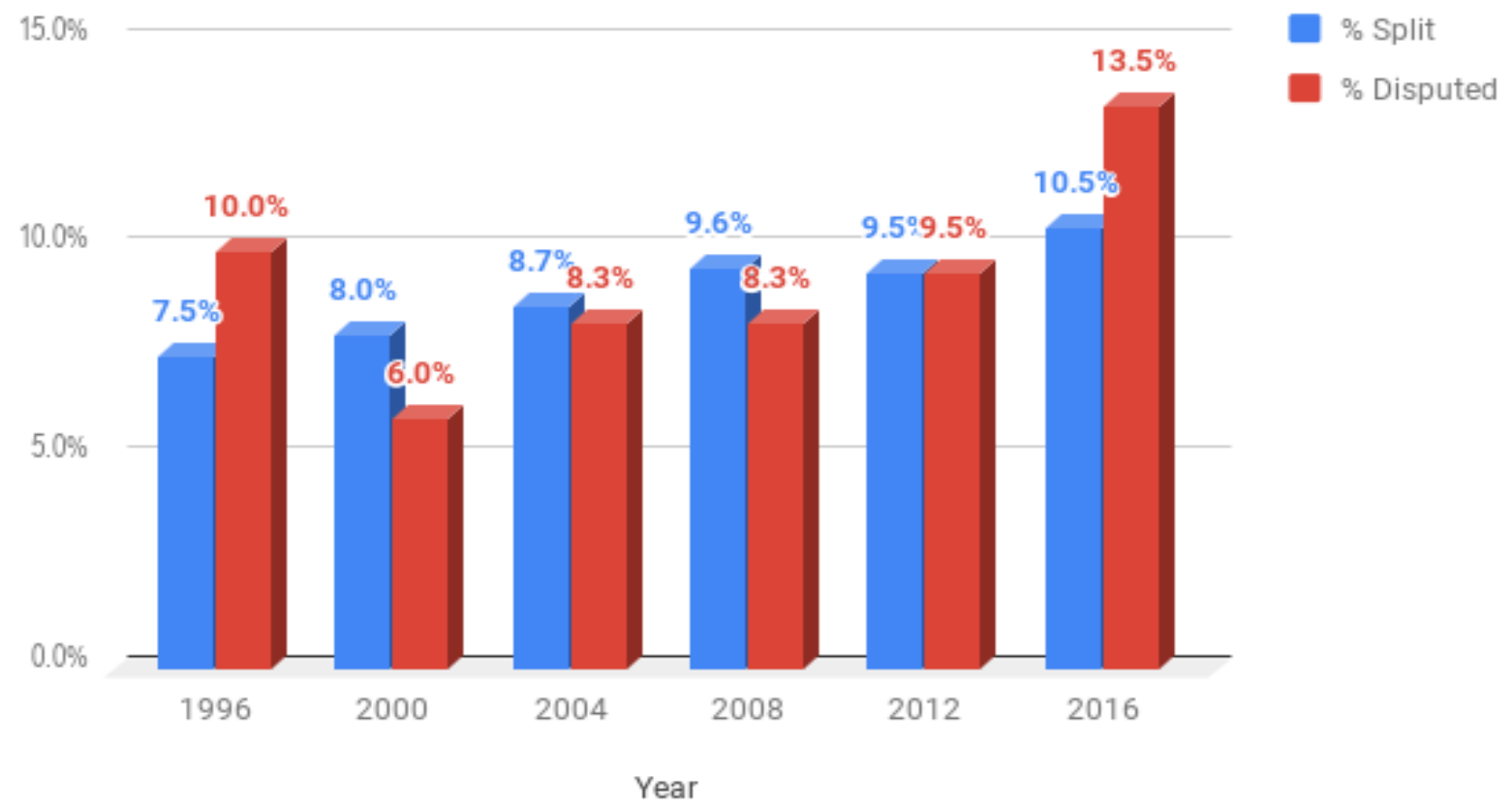

Source: Created by author using data from Election Passport and Ghana Electoral Commission

Second, the aggregate level analysis examines how voter level factors such as volatility and SF-ratio and elite level factors such as disputed primaries in parliamentary elections, deals/alliances, and effective number of political parties affect split outcomes especially in the parliamentary race. Using the constituency-level electoral dataset (1996-2016) alongside published works that show constituencies with disputed primaries in parliamentary elections as well as deals entered into by political parties, the dissertation demonstrates how coordination influences split outcomes. The model controlled for three variables: regional effects, ethnicity, and distance to accommodate alternative explanation. Interestingly, the control variables were not all that significant. Each of the elite coordination variables: disputed primaries in parliamentary elections, deals, and effective number of political parties were highly significant with the signs in 
the expected direction. The voter level coordination factors: volatility and SF-ratio were not supported by the model. Furthermore, the signs of the voter-level factors were not in the expected direction indicating that voter-level factors by themselves are not very effective and will need some sort of influence from the political environment to influence splitting. This sort of influence from the political environment comes from elite coordination which is in tandem with the strategic coordination model that this dissertation advocates (Cox 1997 2006; Kitschelt et al. 1999; Rose \& Munro 2003).

The third level of analysis was at the elite level where the variables of interest were intraparty coordination, interparty coordination, and candidate quality using fieldwork carried out in 2017 sampling 303 respondents made up of party elites and card bearing members of five Ghanaian political parties. Also sampled were members drawn from academia, the media and civil society. Given the target group, the sample was not randomly selected but purposively selected to cover all of these important groups, especially party officials from constituencies that have experienced skirt and blouse outcome and those that have not. Again, persons at the center of skirt and blouse voting (party officials advocating ticket splitting or threatened with it) and those who were not were sampled. To accommodate alternative explanations, the model controlled for education, party ID and restricted choice menu to make sure that alternative factors that influence splitting are considered. Successful primaries which is intraparty coordination variable was statistically significant in all the models with the signs in the expected direction. Again, endorsement was highly significant in all the models. These findings are consistent with the political realities in the Ghanaian political scene where elite coordination successes and failures have shaped party support and have caused significant shifts in parties' vote share since 1992 (Graham et al. 2017; Kumah-Abiwu 2017; Lindberg 2007, 2013; Weghorst \& Lindberg 2013). 
Samuel K. Darkwa

\subsection{CONTRIBUTION TO THE SPLIT-TICKET VOTING LITERATURE}

The contribution of this dissertation to the existing literature can be classified into four. First, the dissertation shows how in-party and cross-party elite coordination explain ticket splitting and consequently split outcome and by extension the composition of the executive and the legislature. It shows how cross-party interaction of party elites can create cohesion even among disunited elites. This kind of elite cohesion has the potential of creating consensually united elites who see politics as bargaining based on the principle of give to get which partly explains Ghana's democratic success. Many people have wondered why Ghana's democracy is seeing progress with repeated peaceful transfers of power even in the wake of closely contested elections (Frempong 2007; Obama 2009; Osei 2015; Whitfield 2009). This dissertation is of the view that this has been possible because the Ghanaian political elites are moving towards the zone of consensually united elites.

Second, ticket splitting affects democratic representation and accountability. In respect to democratic representation, electorates who want their votes to count do not vote based on partisan identification but based on candidate quality. In this way, elections give voters the opportunity to select the most viable candidates in the different races which can potentially create ticket splitting in situation where the most viable candidates in the different races are not from the same political party. The study also shows that ticket splitting better ensures political accountability in the sense that it sends a clear message to political actors that voters expect competence and that it (ticket splitting) has a way of promoting individual accountability by punishing incompetence and rewarding competence. 
Third, the dissertation has reclassified Ghana's skirt and blouse voting which has two different meanings and therefore creates conceptual ambiguity into skirt and blouse voting and skirt and blouse outcome. This reclassification harmonizes Ghana's skirt and blouse voting with split-ticket voting on one hand and skirt and blouse outcome (split district outcome) on the other. In this way, the dissertation has made it possible to compare Ghana's ticket splitting with ticket splitting in other settings.

Finally, it makes the case that, though ticket splitting is seen as voter level phenomenon, it could be studied from elite perspective as well. This is because, politics is largely elite driven; "if elites choose to practice liberal democratic politics, then liberal democratic politics will be practiced" (Higley and Burton 2006, 3). Since political elites are critical in the determination of democratic success and elite interaction affects the available choice set in elections, it is important to study how elite coordination affects ticket splitting and democratic success.

\subsection{LIMITATIONS OF THE RESEARCH}

In spite of the significant contribution made by this dissertation to the Ghanaian skirt and blouse voting and hence the split-ticket voting literature, the dissertation is saddled with two major limitations all related to the dataset used for the analysis. First, the Afrobarometer dataset employed for the individual level analysis in chapter 3 presented three major challenges: differences of objective of the Afrobarometer and my dissertation, timing of data collection, and respondents' decision not to answer some questions leading to significant number of missing data. In fact, because ticket splitting was not the goal of the Afrobarometer in its data collection, the survey questions did not directly assess behavior or voting intentions that will cause ticket splitting. As a result, I resorted to the use of proxies to obtain my dependent variable - split-ticket voting. 
Again, the Afrobarometer survey was not carried out immediately before or after elections to survey voter intentions and their actual voting decisions. It would have been great to explore how voter coordination can even lead to reduction in ticket splitting but the data did not allow me to analyze this fact. For instance, a voter's preferred choice may be party 'A' for president and party ' $\mathrm{B}$ ' for legislature, but this voter may end up choosing party ' $\mathrm{A}$ ' for both president and legislature because party 'B's legislative candidate is subpar. Due to the absence of this critical factor, my assessments of likely voter behavior may understate or overstate skirt and blouse likelihood. Furthermore, a significant number of respondents did not identify with a party when asked in the interview, as well as failed to answer some of the questions. This increased the number of missing data in almost every variable used by the dissertation. I had to resort to the use of multiple imputation technique to handle missing data. Aside from these, the dataset did not allow me to find out which parties and candidates failed to coordinate.

The second major limitation has to do with the measurement of disputed primaries in parliamentary elections, a major elite level independent variable used in chapter 4. As shown in that chapter, in Ghana, elites coordination problem like disputed primary involving nomination mainly occurs due to lack of internal party democracy. Where this happens, and elites are unable to resolve the dispute, in most instances, the aggrieved nomination seekers rally their supports to contest the election as independent candidates. This often divides the party's votes and if the party's main opponent commands similar vote share, then electorates who will like their votes to count are likely to vote for their next preferred candidate. If the party that voter selects in the other race is from a different party, that will cause ticket splitting. To measure disputed primaries in parliamentary elections, the dissertation relied on published works and media reports that have recorded constituencies with disputed party primaries. After compiling all constituencies with 
parliamentary disputed primaries from the reports, the dissertation was unable to distinguish constituencies where just one party had a disputed primary and where more than one party had disputed primaries in parliamentary elections to measure the variable (disputed primaries) in percentages. Consequently, I had to measure disputed primaries in parliamentary elections as dichotomous variable instead of in percentage which is a preferred measure. This measure could cause false negatives, especially in instances where I may incorrectly indicate the absence of disputed primary in some constituencies. It worth pointing out, however, that it is a better evil to under report the presence of a disputed primary than to over report it.

The final limitation, though minor, is the choice of Ghana as the laboratory to examine the relationship between elite coordination and split-ticket voting. This is because the findings from Ghana may not be generalizable to the rest of Africa and emerging democracies. This nonetheless, the choice of Ghana allows the dissertation to go more in depth into how elite coordination influences ticket splitting. This could be replicated elsewhere in single country case and in multiple case research. In fact, I hope to expand this research to cover other West African countries as well as other democracies in Sub-Saharan and Northern Africa.

\subsection{RECOMMENDATIONS FOR FUTURE RESEARCH IN THE SUBFIELD}

From the afore going discussions, it is clear that, examining ticket splitting from the prism of strategic coordination has expanded our knowledge on how elite- and voter-level factors interact to influence the phenomenon. Notwithstanding the contribution the dissertation has made to the split-ticket voting literature, the chapter will suggest few things that future research into ticket splitting should also consider. First, it will be great to ask questions aimed at investigating why party elites will strategically encourage split-ticket voting. Also important are questions that will 
seek to explore how elite coordination successes and failures facilitate ticket splitting. Such questions will help advance the work of scholars who have found individual level factors to be inadequate in explaining why ticket splitting occurs (Burden and Kimball 1998, 2009; Bybee et al. 1981; Campbell and Miller 1957; Roscoe 2003).

A second area worth considering is how ticket splitting and for that matter, split outcomes promotes performance-based voting such as economic voting (Debrah 2016; Downs 1957; Fiorina 1981; Helmke 2009). Performance voting has received much research attention from students and scholars of electoral studies (Anderson 2007; Downs 1957; Fiorina 1981; Hellwig and Samuels 2008; Helmke 2009; Kayser and Wlezien 2011; Moehler and Lindberg 2009). However, comparative study on how split and non-split constituencies may receive differentiated responsive and accountable representation that may produce variations in socioeconomic and human development is lacking (Asunka 2016, 2017; Fridy 2006; Lindberg \& Morrison 2008; Weghorst \& Lindberg 2013). Future research examining such differences is likely to enhance our knowledge on the instrumental role of ticket splitting (split outcomes).

Third, in my fieldwork in Ghana, I uncovered how the financing of opposition election campaigns contributes to the phenomenon of skirt and blouse voting (skirt and blouse outcomes). It was alleged that some politicians sponsor the campaign costs of their opponents with the view that the recipients of such funds will find faults with their party's nomination process. When this happens, the party whose member plays the 'traitor' role rallies support and contests the election as independent candidate. Such acts often divide the votes of the traitor's party and consequently, enhance the chances of the financier's party to win the election. This invariably promotes ticket splitting in the recipient's party. Future research into how such acts facilitate splitting will help 
party elites, policy makers and watchers of democracy craft solutions designed to salvage emerging democracies from certain vices that impede responsive and accountable representation.

Fourth, where individual level factors explaining ticket splitting were considered, political information variables such as radio, newspaper and television presented inconsistent relationship with ticket splitting. This shows that the political information variables could be tools to disseminate public opinion in vogue at the time of an election to influence voter choice in certain direction (Chandra 2007, 2009; Mclaughlin 2008). It will therefore, be interesting to investigate how politicians employ political information variables to influence ticket splitting. At start, it will be important to determine the relationship between split-ticket voting and political information in respect to its direction. A negative direction will mean political information does not influence ticket splitting while positive relationship will indicate that political information impacts splitting.

Finally, this dissertation holds that, though ticket splitting was definitely not one of the objectives of the Afrobarometer in its data collection, collecting data on it will help advance the comparative study of African politics because other barometers do that. Thus, data collection on voter intentions that can help determine whether voters will split their ticket would be helpful. This may not require much space nor costs because already there is a question line that requires voters to indicate the party they will vote for in the presidential race if elections were held tomorrow. Additional questions that will find out which party the voter will vote for in the parliamentary race will help figure out split-ticket voters. The next question worth looking into is who the voter voted for in the parliamentary and presidential races in the previous election. This question will help determine voters' consistency of ticket splitting. 
Samuel K. Darkwa

\subsection{REFERENCES}

Anderson, Christopher J. 2007. "The End of Economic Voting? Contingency Dilemmas and the Limits of Democratic Accountability." Annual Review of Political Science 10. 271-96.

Asunka, Joseph. 2016. "Partisanship and Political Accountability in New Democracies: Explaining Compliance with Formal Rules and Procedures in Ghana." Research \& Politics 3.1.

Asunka, Joseph. 2017. "Non-Discretionary Resource Allocation as Political Investment: Evidence from Ghana." The Journal of Modern African Studies 55.1 (2017): 29-53.

Atwood, L. Erwin, and Keith R. Sanders. 1975. "Perception of Information Sources and Likelihood of Split-Ticket Voting.” Journalism Quarterly 52.3: 421-428.

Barak, Obama. 2009. "Remarks by the President to the Ghanaian Parliament Accra International Conference Center Accra, Ghana". Whitehouse Archives. Retrieved on July 2, 2019, from https://obamawhitehouse.archives.gov/the-press-office/remarks-president-ghanaian-parliament

Beck, Paul Allen, Lawrence Baum, Aage R. Clausen, and Charles E. Smith, Jr. 1992. "Patterns and Sources of Ticket Splitting in Subpresidential Voting." American Political Science Review 86:916-28.

Burden, Barry C., and David C. Kimball. 1998. "A New Approach to the Study of Ticket Splitting." American Political Science Review 92:533-44.

Burden, Barry C., and David C. Kimball. 2009. Why Americans Split their Tickets: Campaigns, Competition, and Divided Government. University of Michigan Press.

Bybee, Carl R., et al. 1981. "Mass Communication and Voter Volatility." Public Opinion Quarterly 45.1: 69-90.

Campbell, Angus, and Warren E. Miller. 1957. "The motivational basis of straight and Split-Ticket Voting." American Political Science Review 51.2: 293-312.

Chandra, Kanchan. 2007. Why Ethnic Parties Succeed: Patronage and Ethnic Head Counts in India. Cambridge University Press, 2007.

Chandra, Kanchan. 2009. "Why Voters in Patronage Democracies Split their Tickets: Strategic Voting for Ethnic Parties.” Electoral Studies 28.1: 21-32.

Cox, Gary W. 1997. Making Votes Count: Strategic Coordination in the World's Electoral Systems. Cambridge University Press.

Cox, Gary W. 1999. "Electoral rules and electoral coordination." Annual Review of Political Science 2.1: 145-161.

Cox, Gary W. 2006. How Electoral Reform Might Affect the Number of Political Parties in the Netherlands. Acta Politica 41: 133-45. 
Debrah, Emmanuel. 2016. "The Ghanaian Voter and the 2008 General Election." Politikon 43.3: 371-387.

Downs, Anthony. 1957. An Economic Theory of Democracy. New York: Addison Wesley.

Fiorina, Morris P. 1981. Retrospective Voting in American National Elections. Yale University Press.

Frempong, Alexander KD. 2007. "Political conflict and elite consensus in the liberal state." In Kwame Boafo-Arthur (ed.), Ghana: One Decade of the Liberal State. Zed Books, pp 128-164.

Fridy, Kevin S. 2006. "The Elephant, Umbrella, and Quarrelling Cocks: Disaggregating Partisanship in Ghana's Fourth Republic.” African Affairs 106.423: 281-305.

Graham, Emmanuel, et al. 2017. "The Third Peaceful Transfer of Power and Democratic Consolidation in Ghana." Journal of Pan African Studies 10.5.

Hellwig T and Samuels D. 2008. "Electoral Accountability and the Variety of Democratic Regimes." British Journal of Political Science 38(1): 65-90.

Helmke, Gretchen. 2009. "Ticket-Splitting as Electoral Insurance: The Mexico 2000 Elections." Electoral Studies 28.1: 70-78.

Higley, John, and Michael Burton. 2006. Elite foundations of liberal democracy. Rowman \& Littlefield Publishers.

Kayser, Mark Andreas, and Christopher Wlezien. 2011. "Performance Pressure: Patterns of Partisanship and the Economic Vote.” European Journal of Political Research 50.3: 365-394.

Kitschelt, Herbert, et al. 1999. Post-Communist Party Systems: Competition, Representation, and Inter-Party Cooperation. Cambridge University Press.

Kumah-Abiwu, Felix. 2017. "Issue Framing and Electoral Violence in Ghana: a Conceptual Analysis." Commonwealth \& Comparative Politics 55.2: 165-186.

Lindberg, Staffan I. 2007. "Institutionalization of Party Systems? Stability and Fluidity Among Legislative Parties in Africa's Democracies." Government and Opposition 42.2: 215-241.

Lindberg, Staffan I. 2013 "Have the cake and eat it: The rational voter in Africa." Party Politics 19.6: $945-961$.

Lindberg, Staffan I., and Minion KC Morrison. 2008. "Are African Voters Really Ethnic or Clientelistic? Survey Evidence from Ghana.” Political Science Quarterly 123.1: 95-122.

Mclaughlin, Eric S. 2008. "Racial, Ethnic or Rational Voters? Splitting Tickets in South Africa." Politikon 35.1: 23-41.

Moehler, Devra C., and Staffan I. Lindberg. 2009. "Narrowing the Legitimacy Gap: Turnovers as a Cause of Democratic Consolidation." The Journal of Politics 71.4: 1448-1466.

Osei, Anja. 2015. "Elites and democracy in Ghana: A social network approach." African Affairs 114.457: 529-554. 
Roscoe, Douglas D. "The choosers or the choices? Voter characteristics and the structure of electoral competition as explanations for ticket splitting." Journal of Politics 65.4 (2003): 11471164.

Roscoe, Douglas D. 2003. "The Choosers or the Choices? Voter Characteristics and the Structure of Electoral Competition as Explanations for Ticket Splitting." Journal of Politics 65.4: 11471164.

Wattenberg, Martin P. 1998. The Decline of American Political Parties, 1952-1996. Cambridge: Harvard University Press.

Weghorst, Keith R., and Staffan I. Lindberg. 2013. "What Drives the Swing Voter in Africa?" American Journal of Political Science 57.3: 717-734.

Whitfield, Lindsay. 2009. "Change for a better Ghana': Party competition, institutionalization and alternation in Ghana's 2008 elections." African Affairs 108.433: 621-641. 